\title{
The Cardiidae (Mollusca: Bivalvia) of tropical northern Australia: A synthesis of taxonomy, biodiversity and biogeography with the description of four new species
}

\author{
Jan Johan ter Poorten ${ }^{1 *}$, Lisa Ann Kirkendale² and Jean-Maurice Poutiers ${ }^{3}$ \\ 1 Department of Zoology (Invertebrates), Field Museum of Natural History, , 1400 S. Lake Shore Drive, \\ Chicago, IL 60605-2496, U.S.A. \\ 2 Department of Aquatic Zoology, Western Australian Museum, Locked Bag 49, Welshpool DC, \\ Western Australia 6986, Australia. \\ ${ }^{3}$ Muséum national d'Histoire naturelle, UMR 7205 ISyEB, CP51, 55 rue de Buffon, F-75231 Paris, France. \\ * Corresponding author: terpoorten@chello.nl
}

\begin{abstract}
Cardiids or marine cockles are one of the best known families of marine bivalves in the world, with a long history of study and collection given their large and accessible shells, a tractable level of biodiversity globally ( 290 species) and a solid fossil record extending to the late Triassic. In Western Australia, the cardiids are well known relative to other marine bivalve families, having been the subject of focussed treatment and consist of 31 species. However, given the proximity to the Indo-West Pacific, sheer size of the state and almost unparalleled number of habitats, the diversity is likely underestimated. Over the last 40 years, ongoing expedition work coupled with taxonomic study by the authors, has resulted in a doubling of the cardiid fauna of Western Australia (WA). Current cardiid diversity now stands at 68 species, including seven species of giant clams (Tridacninae). Subfamilial representation has changed little (except for the addition of Tridacninae previously in its own family, the Tridacnidae), and key genera in Cardiinae (e.g. Fulvia), Fraginae (e.g. Fragum) and Trachycardiinae (e.g. Acrosterigma and Vasticardium) still deliver much of the diversity. This updated biodiversity census has implications within and beyond Western Australia, with 16 new species records for the state and 14 new records for Australia, including four new species: Acrosterigma extremattenuatum sp. nov., Ctenocardia pilbaraensis sp. nov., Microcardium scabrosum sp. nov. and Pratulum occidentale sp. nov. Further taxonomic decisions include recognition of Vasticardium serricostatum (Melvill \& Standen, 1899) and Lunulicardia tumorifera (Lamarck, 1819) as distinct species. Vasticardium swanae Maxwell, Congdon \& Rymer, 2016 is considered a new synonym of Cardium variegatum G.B. Sowerby II, 1840; Vasticardium lomboke Vidal, 2003 is considered a new synonym of Cardium mindanense Reeve, 1844 and Acrosterigma abrolhense Vidal, 1999 is considered a new synonym of Cardium cygnorum Deshayes, 1855. All subspecies in the Vasticardium elongatum (Bruguière, 1789) complex are raised to species level.
\end{abstract}

New acquisitions arising from tropical survey work in the north have yielded all of the newly added species and all newly described species in the Western Australian Museum (WAM) cardiid collections. This is in contrast to the relatively stable biodiversity of southwestern Western Australia. In the north, diversity is highly structured with sixteen taxa found restricted to offshore islands and shoals (e.g. Vasticardium philippinense (Hedley, 1899), V. elongatum (Bruguière, 1789), Corculum cardissa (Linnaeus, 1758), Ctenocardia fornicata (G.B. Sowerby II, 1840), C. gustavi Vidal \& Kirkendale, 2007), and a smaller cohort found exclusively inshore (e.g. A. extremattenuatum sp. nov., V. wilsoni (Voskuil \& Onverwagt, 1991), C. pilbaraensis sp. nov.). Biodiversity comparisons are made with other tropical states in northern Australia, including the Northern Territory (NT) and Queensland (Qld), and considered together these records support recognition of a vast Dampierian Province. Regional biogegraphic comparisons are also made to examine whether cardiids in northern Australia are as diverse as other central Indo West Pacific (IVP) areas. To improve management of the commercially important Tridacninae (giant clams), we provide the first formal records of species diversity and distribution in this group for WA. While cardiids are relatively well characterised, persistent gaps remain that are not unique to this family. Our knowledge of small and/or cryptic species, as well as the deep water fauna broadly, lags behind our understanding of shallow water macromolluscs.

KEYWORDS: Indo-West Pacific, Western Australia, Northern Territory, distributions, endemism, survey, cockles, giant clams

urn:Isid:zoobank.org:pub:C0659F22-ACFD-4B02-9DE4-748000C73FA1 


\section{IN MEMORY OF BARRY WILSON (1935-2017)}

'Probably most of the common and conspicuous shells, those which first attract attention, are here represented. But this number will be increased perhaps fourfold when small species and those from deep water are collected.'

(Hedley 1916: 152)

\section{INTRODUCTION}

\section{BACKGROUND}

In their revision of the Cardiidae of Western Australia, Wilson and Stevenson (1977) reported and described 31 species from the WA coast (Tridacninae excluded), four of which were described and named as new (Table 1). This often cited regional monograph provided taxonomists with a wealth of information; by drawing attention to deficiencies in the generic nomenclature, it formed a valuable benchmark for subsequent malacologists dealing with this family. This work also integrated specimens from a number of important surveys in WA including; (1) the early work of Sir Joseph Verco on the deep shelf benthic molluscs of the Southern Australian Realm, including sites off the southern coast of WA, (2) the Western Australian Museum dredging expeditions (1965 onwards) on the north west and west coasts, viz: Hawaiian WA Expedition on 'Davena', 'Bluefin' and other chartered commercial trawlers, (3) the two West Coast outer shelf surveys aboard the Royal Australian Navy (RAN) frigates 'Diamantina' and 'Gascoyne' converted for service in the national oceanographic program; (4) collaboration on a number of occasions with CSIRO on oceanographic cruises, as well as (5) the targeted onshore surveys of molluscan faunas in Cockburn Sound, the Houtman Abrolhos Islands, Shark Bay, Ningaloo Reef, Barrow Island and the Dampier Archipelago.

Since this work focussed in WA, cardiids have received ongoing global attention, including a fully annotated and illustrated bibliography of living and fossil species (Hylleberg 2004), reviews at generic and subfamilial levels (ter Poorten 2005, 2013, Vidal 1994, 1999), regional monographs (ter Poorten 2009), phylogenetic study (Schneider and Ó Foighil 1999, Kirkendale 2009, Herrera et al. 2015) and the recognition of new species (e.g. ter Poorten 2009, 2015, Poutiers 1981, 2006, Su et al. 2014, Monsecour 2016). Not only has our knowledge of cardiid biodiversity, relationships and distributions improved, but the amount of material available for study has also increased, owing to numerous expeditions conducted by several museums and institutions (see 'Abbreviations' for museum and institutional material incorporated in this study). Much of this collecting has focussed on the highly diverse Indo-West Pacific, including the northern coast of WA. The incorporation of a greater diversity of sampling methods on many of these expeditions has contributed to improved taxonomic coverage in previously neglected habitats.

\section{WESTERN AUSTRALIA WITHIN A BROADER BIOGEOGRAPHICAL SETTING}

At the largest scale are the marine biogeographic zones, which are largely structured by temperature (e.g. tropical, warm temperate, cold temperate and cold) (e.g. Briggs and Bowen 2012). These have remained relatively stable through time (e.g. compare Ekman 1956, Briggs 1974, Harzhauser et al. 2002, with Briggs and Bowen 2012 and Wilson 2013). Within these zones, biogeographic regions (Briggs 1974) can be further delineated, and the recognition of divisions, but also connectivity, among ocean basins is an important consideration at this scale (e.g. 14 shelf regions and provinces outlined by Briggs and Bowen 2012, these roughly correspond to the realms of Harzhauser et al. 2002, as followed by Wilson 2013). Below these two higher order biogeographic levels (of zone and region), the introduction of new methods and/or improved datasets, are altering traditional world views.

Provinces have been used to denote areas of physical and faunal distinction with $10 \%$ endemism, a pervasive metric that is followed here (Briggs and Bowen 2012, Wilson 2013). Integration of recent research, such as phylogeography, has provided new data of relevance to assessing species richness and endemicity for coral reef fish, which has in turn altered delineation of provinces in some biogeographic studies (e.g. globally: Briggs and Bowen 2012, Kulbicki et al. 2013; south Australia: Waters et al. 2010). Below the provincial level, two works are of recent significance and these are the global ecoregion classification system (Spalding et al. 2007) and in Australia, the IMCRA system of bioregions (e.g. IMCRA, Thackway and Cresswell 1998).

In WA, two distinct regions are widely recognised. These are the Southern Australian and Northern Australian regions of Wilson (2013), with the Western Overlap Zone off Geraldton/Houtman Abrolhos Islands separating the two. The south is predominantly a 
temperate fauna, while the north is largely a tropical fauna. These regions correspond to Briggs and Bowen's (2012) Western Pacific region in the south and tropical IWP region in the north (see discussion below for conflicts).

Within the Southern Australian region, Wilson (2013) recognises two distinct provinces, a Southwestern Province and a Southeastern Province (Wilson 2013: 9, Fig. 1.3). The break between these two areas is not well specified by Wilson and Gillett (1971: 17-18) and no strict endemism criteria (e.g. 10\% threshold) are discussed. These boundaries instead are based on expert knowledge of regional faunal diversity and distribution, as well as historical concepts delineated by others, notably and of relevance to the southwest of WA, is the Flindersian of Whitley (1932) (previously the Adelaidean of Hedley $(1904,1926))$. The Flindersian Province extends from southwestern WA, across South Australia and to the western edge of Victoria. The Flindersian Province abuts: 1) the Maugean to the south (including Tasmania) and 2) along the continent, the Peronian (that subsumes all of New South Wales (NSW)). Waters et al. (2010) utilised an extensive dataset on marine algae to quantitatively test southern Australian provincial boundaries and found support for Flindersian, Peronian and Maugean Provinces, refining extension of the Maugean to southern NSW, with a slight shift in the boundary of the Maugean-Flindersian in Western Victoria. Within the Western Pacific region of Briggs and Bowen (2012) five provinces are differentiated, and consistent with others, is the recognition of a Warm Temperate Province in southwestern Australia. This is the only province discussed in the Western Pacific region that is not technically in the Western Pacific ocean, but in the Indian Ocean. The warm temperate province in southwestern Australia recognised by Briggs and Bowen (2012) aligns closely with the Southwestern Province of Wilson (2013).

To the north, WA is part of the tropical IWP region. The tropical IWP region or realm has long been recognised as the largest and richest marine biogeographic region in the world, extending from Africa in the Indian Ocean across to Easter Island in the Central Pacific Ocean (Forbes 1856, Ekman 1956, Briggs 1974, Spalding et al. 2007, Briggs and Bowen 2012, Wilson 2013). The pinnacle of marine diversity, the central IWP (also known as the Indo-Malay Archipelago, East Indies Triangle or Coral Triangle), bordered by the Philippines, Indonesia, Papua New Guinea and the Solomon Islands, lies in the centre of this region (Veron et al. 2009, 2015). Surveys over the last several decades have added greatly to improving the biodiversity estimates here (i.e. Bouchet 2009, ter Poorten 2009), which in turn allow improved faunal comparison with neighboring areas.
Wilson (2013) outlines a Northern Australian region and recognises two distinct provinces, a Northwestern Province and a Northeastern Province (Wilson 2013: 9, Fig. 1.3). Distinction at the provincial level in the north was historically recognised and is supported by Wilson (2013: 9-10). For example, Whitley (1932) outlined four provinces: 1) Dampierian Province (Hedley 1926) extending from Shark Bay (WA) to the Gulf of Carpentaria (Qld); 2) the Solanderian Province that incorporates the Great Barrier Reef and extends from the Gulf of Carpentaria (Qld) to approximately Gladstone (Qld); 3) the Banksian (coastal Qld) and 4) the Phillipian (Norfolk and Lord Howe Islands). Surprisingly, Wilson and Stevenson (1977) argued against recognition of a distinct Dampierian Province, even though cardiid species counts indicated $15 \%$ endemism (4/27 endemics). While these classic subdivisions are moderately different to Wilson (2013: 9-10), they contrast even more significantly with Briggs and Bowen (2012).

Revisiting the concept of a Dampierian Province is relevant to this study given the application of cardiid data to retesting its efficacy (Wilson 2013: 9-10), but also the dominant role that WA plays in the tropical north. Within WA, this tropical province includes an enormous diversity of habitats, geology and history under the sway of a wide range of often seasonal oceanographic influences. Notable areas within this large province include the wide continental mid-shelf area referred to as the North West Shelf (Rowley Shelf to the south and Sahul Shelf to the north), numerous offshore or oceanic islands, shoals and atolls to the west of the shelf, inshore areas of the coastal Kimberley, Canning and Pilbara as well as important features of the southern boundary of the province, including Shark Bay and adjacent Ningaloo and Exmouth Gulf, and the Northwest Cape area (Wilson 2013). The Dampierian Province comprises five ecoregions in WA (Spalding et al. 2007: 210, 145, 144, 141 and 140) and 27 IMCRA bioregions (Integrated Marine and Coastal Regionalisation for Australia) (Thackway and Cresswell 1998) (see Wilson 2013: 10, fig. 1.5; Figure 1). Within this area two major distinctions are considered that are best highlighted using IMCRA bioregions: the inner or coastal continental zone of WA (Bioregions NIN, PIO, PIN, NWS, EMB, CAN, KSD, $\mathrm{KIM}, \mathrm{BON}, \mathrm{CAB}$ ), and the outer or offshore oceanic shelf of WA (Bioregion OSS) (Figure 1). To place in perspective the scale and complexity of these regions, the IMCRA bioregion NWS refers to the North West Shelf, a large area of continental shelf that is itself the subject of an entire book (Wilson 2013).

Southwestern WA has historically been considered part of the Flindersian Province (Adelaidean of Hedley 1926), a large province that extends from Perth to western Victoria (Wilson 2013, Waters et al. 2010, Colgan 2015). The south coast of Australia broadly has 
an exceptionally high level of molluscan endemism estimated as $75 \%$ (Huber 2010) or even up to $95 \%$ (Wilson and Allen 1987, Ponder et al. 2002). In WA, this region begins approximately at Shark Bay and extends south, encountering the cold Southern ocean across the Great Australian Bight to the border with South Australia. This area is comprised of five ecoregions (Spalding et al. 2007: 211, 209, 208, 207, 206) and 12 bioregions as defined by IMCRA (Thackway and Cresswell 1998, Figure 1: ABR, CWC, LNE, WSC, EUC, MUR, EYR, SG, NSG, SVG, COR, OTW). The area between Shark Bay and Cape Naturaliste or Cape Leeuwin, mentioned in the preceding paragraph, is regarded as the Western Overlap Zone (Wilson 2013: 9, Fig. 1.3). This small transitional area is comprised of two ecoregions (Spalding et al. 2007: 211 and northern part of 209) and five bioregions as defined by IMCRA (Thackway and Cresswell 1998, Figure 1).

\section{ABIOTIC FORCES AND BIOTIC IMPLICATIONS}

This paper with a focus on cardiid taxonomy is not a comprehensive treatment of earth history and related topics in WA. For this, we refer the reader to Wilson (2013) (and references therein).

The latitudinal diversity gradient is strong in WA with higher diversity in the tropical northern fauna and a comparatively depauperate fauna in the south. While the tropical northern fauna is shared with much of the IWP, the south has a much higher degree of endemism. Factors responsible for this pattern are complex but include geology and oceanography through time. Major geological events have significantly altered the landscape of WA in the distant past (the Cenozoic, the last 66 million years) with a prolonged sequence of tectonic and sedimentary events, followed by sea level changes in the recent past especially in the Quaternary (the last 2.6 million years). These events have created the diverse coastline of WA, from the deep sea trenches of Perth canyon in the southwest to, for example, the two significant geological features of the north (Kimberley Basin and Pilbara Craton) (Wilson 2013). More recently, sea level transgressions and regressions have made available differing amounts of habitat for marine biota that not only influence ecological communities but also regulate connectivity of marine populations through time.

Oceanographic effects via current systems also serve to move propagules along the extensive and north-south oriented coastline (motile adults and also planktotrophic larvae) and thus influence connectivity. Significantly, the coast of WA is influenced by a southward flowing warm offshore current, known as the Leeuwin Current (Wilson and Kirkendale 2016). Southward penetration of this current is annually variable, but when strong can carry larvae and thus taxa from more northerly waters southward (via the Indonesian Through Flow or ITF that then connects with the Holloway and Leeuwin currents in WA). This can extend penetration of the northern IWP fauna along the WA coast seasonally (Wilson and Allen 1987, Richards et al. 2016, Wilson 2016).

Major drainages of coastal river systems along the WA mainland as well as massive tidal cycles contribute and/or resuspend significant amounts of sediment. This resource can sustain feeding planktotrophic larvae and filter feeders but also inhibit settlement of certain molluscs. Offshore there exist an array of shoals, islands and atolls and as some of these geological features do not exist near shore, they offer unique habitats. Moreover, environmental conditions differ significantly between inshore and offshore settings. Large river systems in the Kimberley, for example, the Fitzroy River (Mardoowarra) generate large amounts of seasonal runoff that result in low turbidity and eutrophic (high nutrient) conditions. This is in contrast to offshore settings where the absence of large river systems precludes high levels of runoff, resulting in clear waters and oligotrophic (low nutrient) seas (e.g. Rowley Shoals). However, similar conditions between onshore and offshore can occur where coastal islands in nearshore habitats are distant from the mainland and therefore removed from the influences of large rivers (e.g. western coast of Barrow Island) or where the continental shelf is narrow and deep water flushes nearshore habitats (e.g. Ningaloo Reef) (Wilson 2013).

Together factors of geology, geography and oceanography have shaped marine faunal biodiversity of WA. As mentioned above, the most marked contrast is a latitudinal gradient with high biodiversity of the tropical northern marine fauna (both offshore and coastal bioregions) compared to that of the warm temperate fauna of the south. The gradual shift and decline of the former southwards within the transition zone, and the converse decline of the warm temperate fauna northwards is apparent across faunal groups.

\section{AIMS}

The main impetus for this project was to improve the taxonomic understanding of cardiids in WA by augmenting the seminal work of Wilson and Stevenson (1977) with the integration of WAM cardiid collections made in the ensuing 40 years. To complete this task required revisiting the collections to improve identifications and clarify species boundaries with the addition of new distributional records, registration of important legacy material, description of new species and updates to nomenclature. The significance of the north to increasing the biodiversity knowledge of WA, led to consideration of cardiid collections from other tropical areas in Australia, including the Northern Territory and to a lesser extent Queensland. This facilitated extension of the study area to the Northwestern Province, roughly coinciding with the Dampierian Province as outlined by Wilson (2013) 
and earlier workers (striped area in Figure 1). An important goal of this study was to apply the newly considered cardiid source dataset to test for support of the Dampierian Province (e.g. provisional conclusion of Wilson (2013: 392-393)). Considered together these data provide the most accurate assessment of cardiids to be developed for WA and Australia, and when considered in partnership with other survey data, such as that made possible by recent MNHN (Paris Museum) efforts, the Central IWP region. This is a rare event; very few invertebrate groups have had this level of recent attention at this scale.

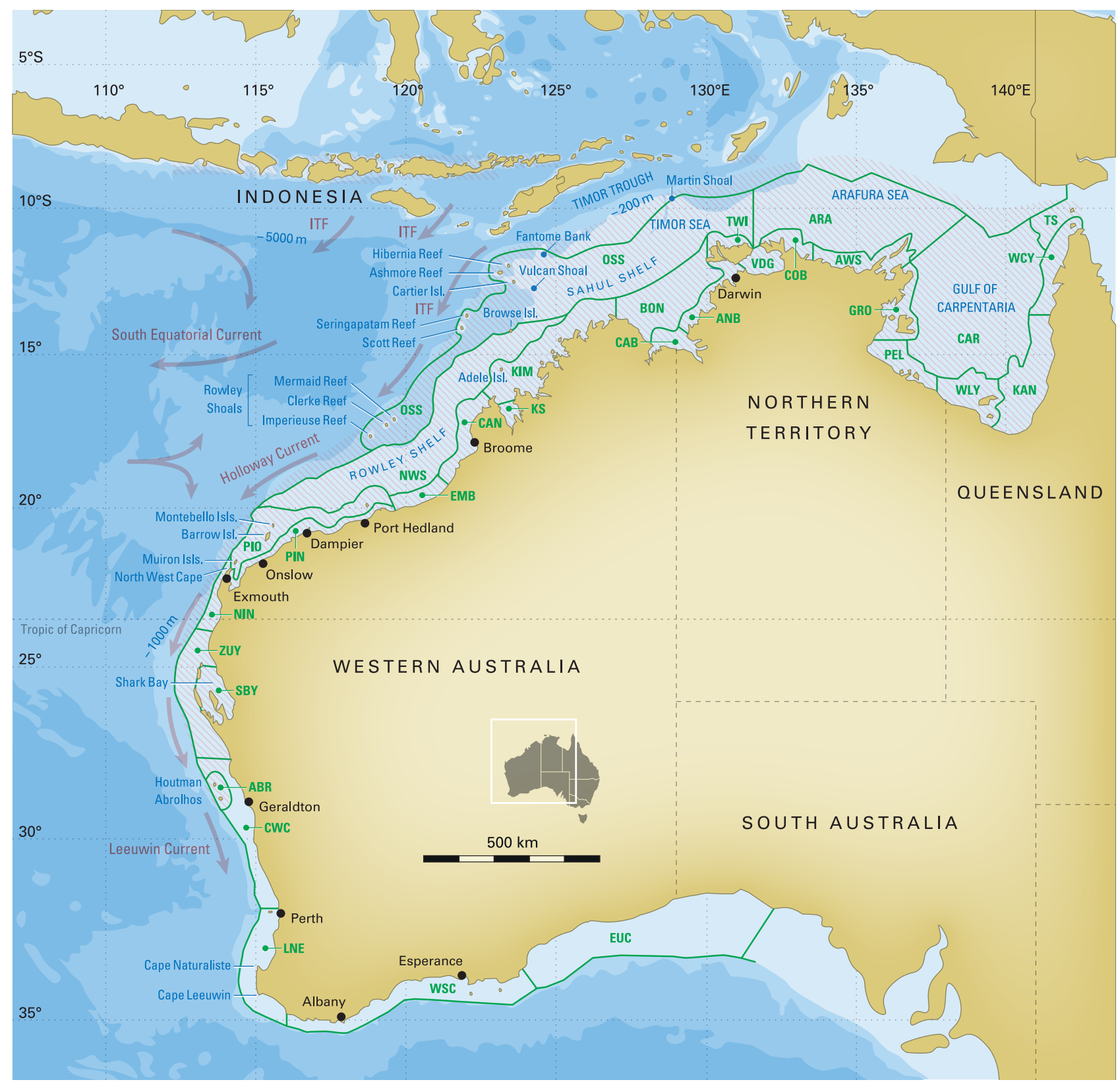

FIGURE 1 Map of north-western Australia showing the main reefs, islands and places referred to in this study. The continental zone $(<200 \mathrm{~m}$ isobath, the shelf edge) is denoted by the lightest blue. Red-brown arrows indicate main oceanic current systems (after Hoeksema 2007; Wilson 2013, 2014). ITF = Indonesian Throughflow. Striped area indicates the primary studied area. Green lines indicate the borders of the IMCRA coastal mesoscale bioregions of Western Australia: TS = Torres Strait, WCY = West Cape York, KAN = Karumba-Nassau, CAR = Carpentaria, $\mathrm{WLY}=$ Wellesley, $\mathrm{PEL}=$ Pellew, GRO = Groote, $\mathrm{AWS}=$ Arnhem Wessel, $\mathrm{ARA}=$ Arafura, $\mathrm{COB}=$ Cobourg, VDG = Van Diemens Gulf, TWI = Tiwi, ANB = Anson Beagle, CAB = Cambridge-Bonaparte, BON = Bonaparte Gulf, CAB = Cambridge-Bonaparte, OSS = Oceanic Shoals, KIM = Kimberley, KS = King Sound, CAN = Canning, NWS = North West Shelf, EMS = Eighty Mile Beach, PIO = Pilbara Offshore, PIN = Pilbara Nearshore, NIN = Ningaloo, ZUY = Zuytdorp, SBY = Shark Bay, ABR = Houtman Abrolhos Islands, CWC = Central West Coast. Beyond the southern limit of the primary studied area, other WA bioregions are: LNE = Leeuwin-Naturaliste, WSC = Western Australia South Coast, EUC = Eucla (after Thackway and Cresswell 1998). 


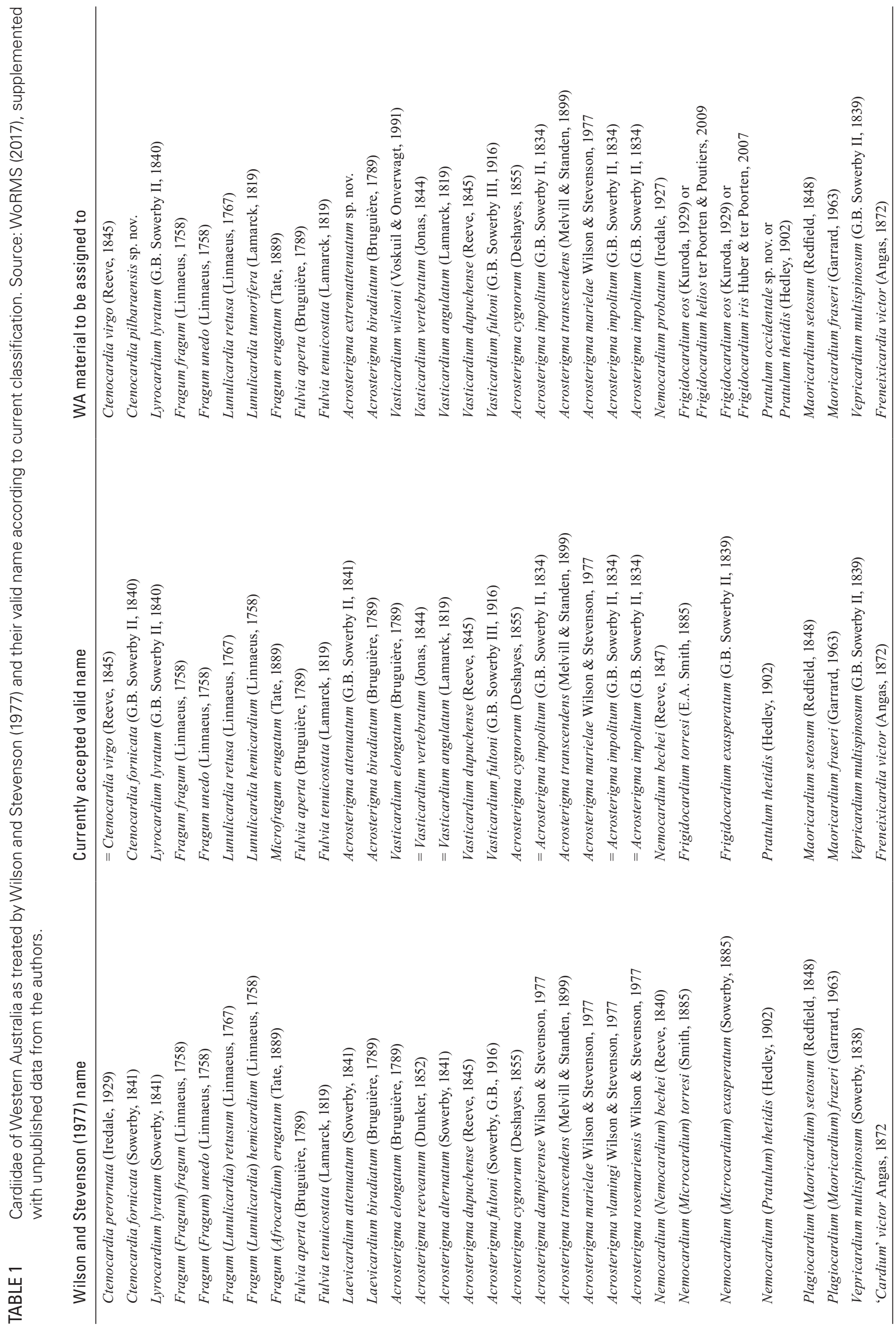




\section{MATERIAL AND METHODS}

The material used in this study largely originates from study of the WAM collections over 10 years. Supplementary sources are other public collections, the reference collection of the first author, other private collections and literature records. Altogether, 1,874 WA Cardiidae samples were examined and verified. Occasional literature records are included that refer to tropical northern Australia and relate to the first recordings for the study area or add to our understanding of the distributions. For comparisons with the diversity of other Australian states and Central IWP areas (Northern Territory (hereafter abbreviated as NT), Queensland (hereafter abbreviated as QLD), Indonesia, Philippines, Papua New Guinea and the Solomon Islands) over 7,400 Cardiidae samples have been examined, identified and documented. To facilitate cross-reference, former WAM registration numbers used by Wilson and Stevenson (1977) are provided in brackets.

The study area for the taxonomomic section initially followed the political boundaries of WA following Wilson and Stevenson (1977): the continental coastal waters of WA and the oceanic emergent reefs of the adjacent shelf margin. Two extremely remote Australian Exclusive Economic Zone (EEZ) areas are excluded: Cocos (Keeling) Islands and Christmas Island, as these are located more than $1,400 \mathrm{~km}$ off the main continent and were not included by Wilson and Stevenson (1977). However, an overview of the cardiid fauna of these latter islands, nearly all of which also occur on the Australian North West Shelf, is given in the Results section. In order to obtain a more complete understanding of the cardiid fauna of tropical northern Australia, the study area includes the Houtman Abrolhos Islands in the south and the NT and the Gulf of Carpentaria in the north east. All newly recorded species (i.e. not covered by Wilson and Stevenson (1977) originate from the tropical part of WA. An overview of the WA cardiid fauna, allowing for direct comparisons with Wilson and Stevenson (1977), is given in the Results section.

For the biodiversity and biogeographical comparisons in the Results section, the scope has been further enlarged, covering the Central IWP and Australia as outlined in Figure 25.

Western Australian species reviewed in this study are limited to those not covered by Wilson and Stevenson (1977); the latter are listed in Table 1 and commented on thereafter. Furthermore, The North/East and South/ East endpoints of species ranges of all WA cardiids as currently defined, based on all verified material, are given in the Results section. Nearly all included species have recently been treated and figured by ter Poorten (2009, 2011) and Huber (2010), hence these works are included where appropriate. Apart from Wilson and Stevenson (1977), Australian literature is limited to the wellknown publications of Lamprell and Whitehead (1992) and Lamprell and Healy (1998). Systematics at subfamily level follow the most recent assessment of cardiid relationships based on molecular phylogeny (Herrera et al. 2015) with genera and species placed in alphabetical order. Lists of material examined are organised geographically north to south and east to west. NW Australian distribution maps are provided for all species not treated by Wilson and Stevenson (1977) for which at least three records could be established (Figures 17-20). Records based on deadcollected material (a category that includes single long dead valves but not subfossils, as well as recently dead paired valves with the ligament intact) are indicated by a black circle, while live records (based on live-collected material) are indicated by a white circle, to provide transparency in distributional and species occurrence data. Given sizes refer to adult specimens, followed after the dash by the maximum observed size (not necessarily of Australian origin).

\section{ABBREVIATIONS}

\section{Acronyms of institutions and repositories}

AIMS Australian Institute of Marine Science, Townsville, Australia

ALA Atlas of Living Australia, http://ala.org.au

AMS Australian Museum, Sydney, Australia

ANSP Academy of Natural Sciences, Philadelphia, United States

CSIRO Commonwealth Scientific and Industrial Research Organisation, Canberra, Australia

MNHN Muséum national d'Histoire naturelle, Paris, France

NHMUK Natural History Museum, London, United Kingdom

NMW National Museum of Wales, Cardiff, United Kingdom

NTM Museum and Art Gallery of the Northern Territory, Darwin, Australia

NMR Natuurhistorisch Museum Rotterdam, Netherlands

OZCAM Online Zoological Collections of Australian Museums, http://ozcam.org.au

QM Queensland Museum, South Brisbane, Australia

RMNH Naturalis Biodiversity Center, Leiden, Netherlands.

TP Colln J.J. ter Poorten, Hilversum, Netherlands

UF Florida Museum of Natural History, University of Florida, United States

WAM Western Australian Museum, Welshpool, Australia

ZMA Zoological Museum Amsterdam, Netherlands (now incorporated in Naturalis Biodiversity Center, Leiden, Netherlands) 


\section{Other abbreviations}

A, found alive; colln, collection; Exped., Expedition; fragm., fragment(s); FRV, Fisheries Research Vessel; FV, Fisheries Vessel; H, height; L, length; l.v., left valve; $\mathrm{MV}$, Motor Vessel; n.o.r., northern offshore reefs; p.v., paired valves; RV, Research Vessel; r.v., right valve; s.v., single valve(s).

\section{TAXONOMY}

\section{PRIOR WORK}

In order to align our work with that of Wilson and Stevenson (1977), the key point of reference for the present study, the currently accepted name and the current identification for each species treated is listed in Table 1. Additional comments on taxa presented in Wilson and Stevenson (1977) immediately follow.

\section{Comments on Wilson and Stevenson (1977) taxa} (Table 1)

\section{Ctenocardia fornicata (Sowerby, 1841)}

All Wilson and Stevenson (1977) records refer to Ctenocardia pilbaraensis sp. nov.; true Ctenocardia fornicata (G.B. Sowerby II, 1840) is known from the outer shelf of WA based on a single record (see under that species).

\section{Fragum (Lunulicardia) hemicardium (Linnaeus, 1758)}

Extensive collection research indicates that the WA population of Lunulicardia hemicardium (Linnaeus, 1758) is limited to a small area ranging from Shark Bay to Exmouth Gulf. This species is neither recorded from the North West Shelf, nor from the Timor Sea, NT or the Gulf of Carpentaria (NT, QLD), and is thus fully separated from its main Central IWP distribution (e.g. QLD). Given its relatively large size and common shallow water occurrence, this distribution is unlikely to have arisen as a sampling artefact, especially considering that the conspecific, L. retusa, has a wide distribution, well documented in WAM collections. This seems an example of allopatric speciation, in need of specific separation, for which the name Cardium tumoriferum Lamarck, 1819 is available. Provisionally, the latter name is employed for WA material that differs by the following characters: antero-dorsal area flattened, lacking radial ribs; rib sculpture on median part consisting of scales rather than tear drop-like papillae; posterior part only slightly protruding and maximum size larger ( $\mathrm{H}$ up to $73 \mathrm{~mm}$ ). This group is currently under study by the second author.

\section{Fragum erugatum (Tate, 1889)}

This species has been placed in five different genera (Hylleberg 2004: 502) given the high variability in characters of shape, hinge and dentition, for example, evident in specimens from the hypersaline environment of Shark Bay, WA. Wilson and Stevenson (1977) placed erugatum in the genus (and subgenus) Fragum (Afrocardium). Later, Schneider (1998) moved erugatum, on the basis of several characters, to Microfragum. More recently, ter Poorten (e.g. 2009) followed Schneider (1998) in this placement, however, Morton (2000) and Vidal (2001) did not. Kirkendale (2009) recovered erugatum firmly at the base of the paraphyletic genus Fragum and sister to $F$. sueziense. Examination of external shell features corroborate placement of erugatum in the genus Fragum, given the beading sculpture aligned with other members of the genus Fragum and not deciduous scales, as found in both representatives of the genus Microfragum (M. festivum, type species of the genus, but also M. subfestivum). This species is photosymbiotic as are all known members of the genus Fragum, along with the two other wholly photosymbiotic genera, Lunulicardia and Corculum. No species of Microfragum have been found to possess symbionts. Characters including gross shell shape, hinge and dentition may be homoplasious and not reliable indicators of phylogenetic relationship for specimens of erugatum from extreme environments. We suggest erugatum be moved from the genus Microfragum and placed in the genus Fragum.

\section{Fulvia aperta (Bruguière, 1789)}

Recorded as far south as Geographe Bay by Wilson and Stevenson (1977). All examined records of $F$. aperta south of Point Cloates proved to belong to a different species, F. tenuicostata (Lamarck, 1819). Compared to material from QLD and Indonesia, the shell exterior of WA populations is covered with dense granulations for a greater shell portion (twothirds), the lunule is tinged with purple and the shell attains larger dimensions ( $\mathrm{L}$ up to $57 \mathrm{~mm}$, ZMA. MOLL.206088). This species is currently under study by the first author.

\section{Laevicardium attenuatum (Sowerby, 1841)}

True Acrosterigma attenuatum (G.B. Sowerby II, 1841) does not occur in WA or the NT. In WA it is replaced by the endemic $A$. extremattenuatum sp. nov. (treated here). Generic placement follows Vidal (1999) with DNA analysis (Herrera et al. 2015) supporting this taxonomic distinction.

\section{Acrosterigma elongatum (Bruguière, 1789)}

Nearshore WA specimens are exclusively in agreement with Vasticardium wilsoni (Voskuil \& Onverwagt, 1991), relegated by Vidal (1993) to a subspecies of Cardium elongatum Bruguière, 1789. See systematic section for treatment of this species and generic assignment. 


\section{Acrosterigma fultoni (Sowerby, G.B., 1916)}

Vidal (1997: 251) applied the name Cardium ornatum G.B. Sowerby III, 1877 for this species that is a junior homonym of Cardium ornatum d'Orbigny, 1850 and Cardium ornatum Eichwald, 1855. The next available name is Cardium fultoni G.B. Sowerby III, 1916.

\section{Acrosterigma dampierense Wilson \& Stevenson, 1977}

See Vidal (1999: 305-308) for arguments considering A. damperiense, A. vlamingi and A. rosemariensis synonymous with $A$. impolitum. Pending additional research, his views are followed here.

\section{Nemocardium (Nemocardium) bechei (Reeve, 1840)}

Ter Poorten (2013) has argued that shape, ribbing and colour of Australian samples differ considerably from that of other provenances, that it is in agreement with Pratulum probatum Iredale, 1927, and that it is to be separated at species level. Ter Poorten (2013) also indicated that among WA and QLD populations differences in morphology and size are present and that distributions are discrete. This study reinforces these findings, as no material is present from NT (except for one WAM record just within the NT boundary) and the Gulf of Carpentaria. Moreover, the QLD population is strongly restricted to the southern part. The shallow and narrow Torres Strait may act as a dispersal barrier, preventing gene flow, hence the presence of sister species pairs seems likely. Given the very limited availability of adult WA samples and lacking the opportunity of molecular testing, we refrain from taxonomic separation.

\section{Nemocardium (Microcardium) torresi (Smith, 1885)}

Although Frigidocardium torresi does occur in WA, all Wilson and Stevenson (1977) records either refer to Frigidocardium eos (Kuroda, 1929) or to F. helios ter Poorten \& Poutiers, 2009. All three taxa are treated in the systematic section.

\section{Nemocardium (Microcardium) exasperatum (Sowerby, 1838)}

Huber and ter Poorten (2007) demonstrated that $F$. exasperatum is restricted from S. Japan to Vietnam. Australian material attributed to this species either involves F. eos (Kuroda, 1929) or F. iris Huber \& ter Poorten, 2007.

\section{Nemocardium (Pratulum) thetidis (Hedley, 1902)}

Ter Poorten (2013) raised Pratulum to generic level. Pratulum thetidis as recognised by Wilson and Stevenson (1977) is a composite of two species, one of these is new to science ( $P$. occidentale sp. nov.) and is treated in the systematic section (see ter Poorten 2013 for further generic explanation).

\section{'Cardium' victor Angas, 1872}

The generic attribution has long been the subject of discussion. Recent phylogenetic research (Kirkendale
2009; Herrera et al. 2015) confirmed that this species is only distantly related to Ctenocardia and the subfamily Fraginae. Ter Poorten (2009) demonstrated that inclusion in Freneixicardia is appropriate.

\section{Taxa not treated by Wilson and Stevenson (1977)}

Recent morphological and molecular phylogenetic research (Schneider 1998; Keys and Healy 1999, Schneider and Ó Foighil 1999 and Herrera et al. 2015) has shown that the tridacnines are a distinct and highly specialised subfamily of the Cardiidae. Giant clams were not treated by Wilson and Stevenson (1977), because they were placed in a separate family, the Tridacnidae at that time. For the purposes of this paper, giant clams are not further treated in the systematic section but enumerated below, with references to their occurrence in WA. Additionally, these seven species are listed in the Results section, including their distributional data (North/East and South/East range endpoints in WA). References to the giant clam species Tridacna noae (Röding, 1798), recently ressurrected from synonymy (Borsa et al. 2015), all relate to dry, non-genotyped material: in some cases tentatively assigned to this species given the limited utility of currently available morphological character data in resolving species boundaries (Borsa et al. 2015, Johnson et al. 2016). Tridacna ningaloo Penny \& Willan, 2014 is considered a junior synonym of $T$. noae. This group is the subject of ongoing research in the region by the second author.

1. Hippopus hippopus (Linnaeus, 1758) - Rosewater (1965); Wells and Slack-Smith (1986); Lamprell and Whitehead (1992); Wells (1993); Willan (2005); Bryce and Whisson (2009).

2. Tridacna (Chametrachea) crocea Lamarck, 1819 Wells Slack-Smith (1986); Lamprell and Whitehead (1992); Wells (1993); Willan (2005); Bryce and Whisson (2009).

3. Tridacna (Chametrachea) maxima (Röding, 1798) - Rosewater (1965); Wells and Slack-Smith (1986); Lamprell and Whitehead (1992); Willan (2005); Bryce and Whisson (2009).

4. Tridacna (Chametrachea) noae (Röding, 1798) - Borsa et al. (2014); Penny and Willan (2014, as T. ningaloo).

5. Tridacna (Chametrachea) squamosa Lamarck, 1819 - Hedley (1921); Wells and Slack-Smith (1986); Lamprell and Whitehead (1992); Wells (1993); Willan (2005); Bryce and Whisson (2009).

6. Tridacna (Tridacna) derasa (Röding, 1798) - Bryce and Whisson (2009).

7. Tridacna (Tridacna) gigas (Linnaeus, 1758) - Wells and Bryce (1985); Wells and Slack-Smith (1986); Lamprell and Whitehead (1992); Wells (1993); Willan (2005); Bryce and Whisson (2009). 


\section{Family Cardiidae Lamarck, 1819}

\section{incertae sedis}

\section{REMARKS}

The genera Frigidocardium, Microcardium, Nemocardium, Trifaricardium and Pratulum treated in the present work were traditionally assigned to Protocardiinae. However, in his cladistic analysis of Cardiidae, Schneider (1995) restricted this subfamily to a group of extinct Mesozoic taxa and classified Nemocardium in Laevicardiinae, together with the subgenera Frigidocardium, Microcardium, Trifaricardium and Pratulum. These taxa were raised to genus by ter Poorten (2013). In their molecular phylogenetic study, Herrera et al. (2015) demonstrated that Laevicardiinae is polyphyletic, with Frigidocardium, Microcardium and Trifaricardium distributed in a clade basal to all other living cardiids; and that Laevicardiinae is sister to Trachycardiinae, both forming the youngest lineages of the family. Unfortunately, the study of Herrera et al. (2015) did not include members of the oldest extant cardiid genera: Nemocardium and Pratulum. Hence, subfamily assignment of these and related genera must await further research.

\section{Genus Frigidocardium Habe, 1951}

Erigidocardium [sic! = Frigidocardium] Habe, 1951: 152 (as a subgenus of Nemocardium). Type species by original designation: Cardium (Fragum?) eos Kuroda, 1929; Recent, Kii Peninsula, Honshū, Japan.

\section{Frigidocardium eos (Kuroda, 1929)}

Figures 2A-F, 17A

Cardium (Fragum?) eos Kuroda, 1929: 93, pl. 3 fig. 5.

Nemocardium (Microcardium) torresi (Smith, 1885) Wilson and Stevenson (1977) 1977: 65-66, pl. 4 figs 20-22, text fig. 8 [pars].

Frigidocardium torresi (Smith, 1885) - Lamprell and Whitehead 1992: pl. 33 fig. 219 (Philippine specimen figured).

Frigidocardium eos (Kuroda, 1929) — ter Poorten 2009: pl. 17 figs 1-4, pl. 20 fig. 3; Huber 2010: 307, fig.; ter Poorten 2011: pl. 1105 figs 5-7.

\section{MATERIAL EXAMINED}

Australia, Western Australia: Oceanic Shoals, Kulumburu L293.4607 ${ }^{\circ} \mathrm{S}, 124.0199^{\circ} \mathrm{E}$ to $13.4726^{\circ} \mathrm{S}$, 124.024ㄹ, $101-104$ m, 06.07.2007. Leg. M.P. Salotti, CSIRO RV 'Southern Surveyor' Cruise, Stn SS0507/171 (WAM S32879, 1 s.v.); North West Shelf, 50 miles N.N.E. of Adele Island, $15^{\circ} 30^{\prime} \mathrm{S}, 123^{\circ} 09^{\prime} \mathrm{E}, 50 \mathrm{fms}$ (91 m), 20.10.1962. Leg. R.W. George, 'Dorothea' (WAM S78147, ex 228-67, 1 s.v.); 25 miles N.N.E. of Adele Island, $15^{\circ} 30^{\prime} \mathrm{S}, 123^{\circ} 09^{\prime} \mathrm{E}, 42 \mathrm{fms}$ (77 m), 20.10.1962. Leg. R.W. George, 'Dorothea' (WAM S78146, ex $326-67,1$ s.v.); Adele Island L28, $14.5622^{\circ} \mathrm{S}, 122.9182^{\circ} \mathrm{E}$ to $14.5614^{\circ} \mathrm{S}, 122.9151^{\circ} \mathrm{E}, 95-105 \mathrm{~m}, 05.07 .2007$. Leg. M.P. Salotti, CSIRO RV 'Southern Surveyor' Cruise, Stn SS0507/161 (WAM S34671, 1 s.v.); Adele Island $\mathrm{L} 28,14.5615^{\circ} \mathrm{S}, 122.9062^{\circ} \mathrm{E}$ to $14.5502^{\circ} \mathrm{S}, 122.911^{\circ} \mathrm{E}$, 135-165 m, 05.07.2007. Leg. M.P. Salotti, CSIRO RV 'Southern Surveyor' Cruise, Stn SS0507/162 (WAM S78304, 1 s.v.); Leveque L27, $15.0945^{\circ} \mathrm{S}, 121.7864^{\circ} \mathrm{E}$ to $15.0916^{\circ} \mathrm{S}, 121.7904^{\circ} \mathrm{E}, 78-79 \mathrm{~m}, 02.07 .2007$. Leg. M.P. Salotti, CSIRO RV 'Southern Surveyor' Cruise, Stn SS0507/140 (WAM S32788, 1 p.v., A); Rowley Shoals, S.E. of Imperieuse Reef L23, $18.4602^{\circ} \mathrm{S}, 120.1447^{\circ} \mathrm{E}$ to $18.462^{\circ} \mathrm{S}, 120.1447^{\circ} \mathrm{E}, 80-81 \mathrm{~m}, 19.06 .2007$. Leg. C. Whisson \& O. Gomez, CSIRO RV 'Southern Surveyor' Cruise, Stn SS0507/082 (WAM S32786, 1 p.v., A; WAM S32865, 25 s.v.); Rowley Shoals, S.E. of Imperieuse Reef L23, $18.4293^{\circ} \mathrm{S}, 120.0981^{\circ} \mathrm{E}, 104 \mathrm{~m}, 19.06 .2007$. Leg. C. Whisson \& O. Gomez, CSIRO RV 'Southern Surveyor' Cruise, Stn SS0507/083 (WAM S32887, 2 s.v.); S.E. of Mermaid Reef, $17^{\circ} 46^{\prime} 6.23^{\prime \prime S}, 120^{\circ} 43^{\prime} 9.12^{\prime \prime} \mathrm{E}$ to $17^{\circ} 45^{\prime} 56.87 " \mathrm{~S}, 120^{\circ} 42^{\prime} 56.51^{\prime \prime E}, 97-109$ m, 20.06.2007. Leg. C. Whisson \& O. Gomez, CSIRO RV 'Southern Surveyor' Cruise, Stn SS0507/097 (WAM S32857, 1 s.v.); $17.7605^{\circ} \mathrm{S}, 120.7111^{\circ} \mathrm{E}, 110 \mathrm{~m}, 19.06 .2007$. Leg. C. Whisson \& O. Gomez, CSIRO RV 'Southern Surveyor' Cruise, Stn SS0507/089 (WAM S32868, 1 s.v.); 84 nautical miles N. of Port Hedland, $18^{\circ} 53^{\prime} 12^{\prime \prime S}, 118^{\circ} 34^{\prime} 12^{\prime \prime E}$ to 18 53'06"S, 118 32'18"E, 89-92 m, 20.08.1982, leg. J. Marshall, CSIRO FRV 'Soela' Cruise IV, Stn SO4B/82/77 (WAM S15909, 1 s.v.); 67 nautical miles N.N.E. of Cape Lambert, $19^{\circ} 31.4^{\prime} \mathrm{S}, 17^{\circ} 26.0^{\prime} \mathrm{E}$ to $19^{\circ} 29.9^{\prime} \mathrm{S}, 17^{\circ} 26.4^{\prime} \mathrm{E}$, on sand, 78 m, 17.08.1995, leg. L.M. Marsh, AIMS Survey RV 'Lady Basten', Stn AIMS/95/LB3 (WAM S15924, 1 s.v.); Pilbara Offshore, 10-20 miles N.N.W. of Anchor Island, Onslow, $21^{\circ} 38^{\prime} \mathrm{S}, 115^{\circ} 07^{\prime} \mathrm{E}$, mud \& gravel, $119 \mathrm{~m}$, 17.06.1960. Leg. B.R. Wilson, R. George \& L. Joll, Mariel King Hawaiian Exped. MV 'Davena' (WAM S35204, ex 248-67, 1 s.v.); Off Barrow Island, $20.9847^{\circ} \mathrm{S}, 114.9070^{\circ} \mathrm{E}$ to $20.9945^{\circ} \mathrm{S}, 114.9090^{\circ} \mathrm{E}, 100-101 \mathrm{~m}, 13.12 .2005$. Leg. S.M. Slack-Smith, \& M.P. Salotti, CSIRO RV 'Southern Surveyor' Cruise SS1005 Nov/Dec 2005, Stn SS1005/170 (WAM S29449, 1 s.v.); Off Barrow Island, $21.0316^{\circ} \mathrm{S}$, $114.8920^{\circ} \mathrm{E}$ to $21.0344^{\circ} \mathrm{S}, 114.8880^{\circ} \mathrm{E}, 93 \mathrm{~m}, 13.12 .2005$. Leg. S.M. Slack-Smith, \& M.P. Salotti, CSIRO RV 'Southern Surveyor' Cruise SS1005 Nov/Dec 2005, Stn SS1005/169 (WAM S29391, 1 p.v., A); Off Barrow Island, $21.0358^{\circ} \mathrm{S}, 114.888^{\circ} \mathrm{E}$ to $21.0332^{\circ} \mathrm{S}, 114.8857^{\circ} \mathrm{E}$, 90-100 m, 10.06.2007. Leg. C. Whisson, CSIRO RV 'Southern Surveyor' Cruise, Stn SS0507/008 (WAM S32784, 1 p.v., A; S32863, 1 s.v.); Ningaloo, W. of North West Cape, 21 ${ }^{\circ} 50^{\prime} \mathrm{S}, 113^{\circ} 46^{\prime} \mathrm{E}, 75 \mathrm{fms}$ (137 m), 06.10.1963. CSIRO HMAS 'Diamantina' Cruise II, Stn DM6/173/63 (WAM S78144, ex 327-67, 1 s.v.); Off Ningaloo (South), $22.0795^{\circ} \mathrm{S}, 113.7960^{\circ} \mathrm{E}$ to $22.0873^{\circ} \mathrm{S}, 113.7940^{\circ} \mathrm{E}, 201-206$ m, 10.12.2005. Leg. S.M. Slack-Smith, \& M.P. Salotti, CSIRO RV 'Southern Surveyor' Cruise SS1005 Nov/Dec 


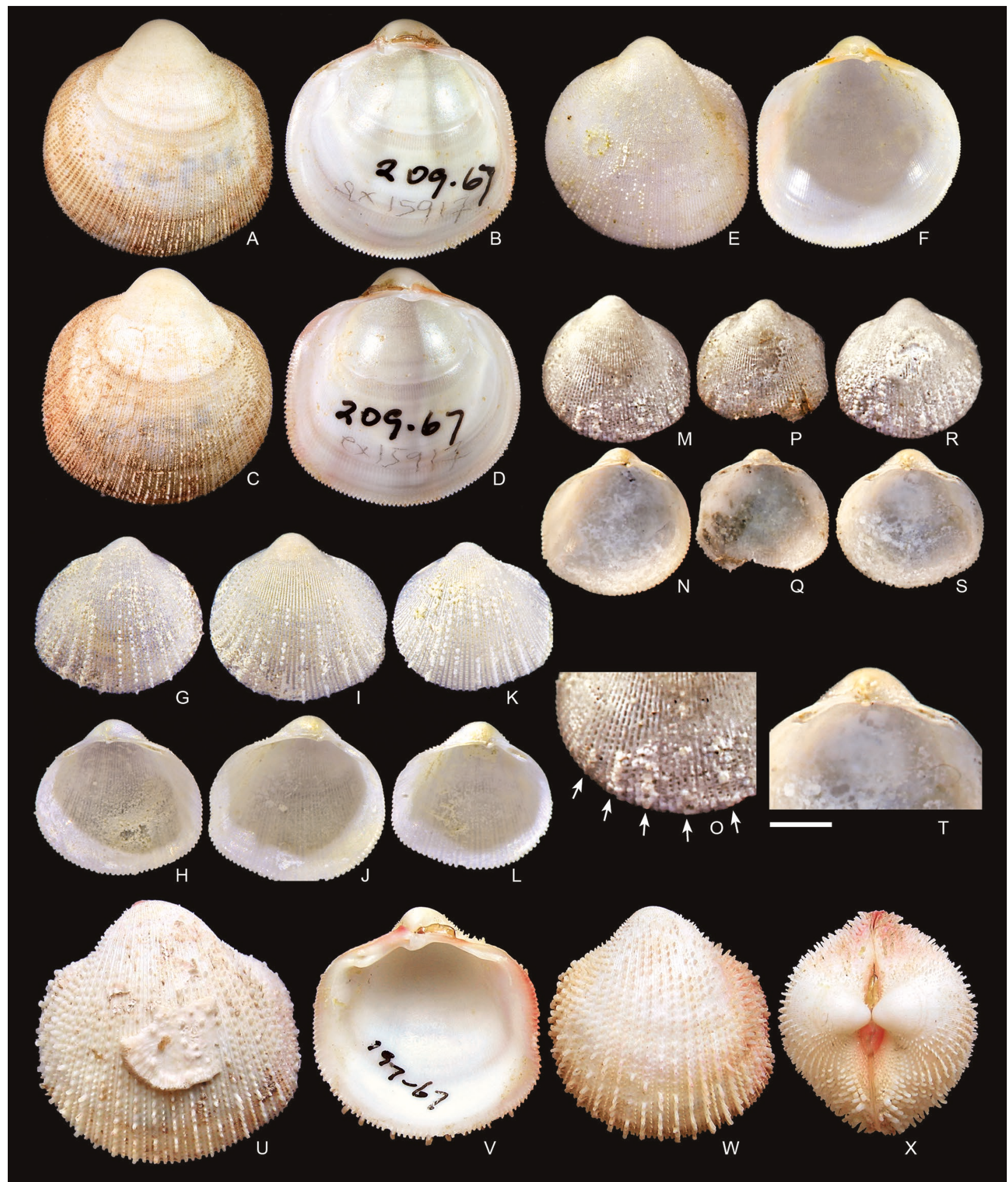

FIGURE 2 A, B, C, D, E, F, Frigidocardium eos (Kuroda, 1929). A-D, W. of Point Cloates, WA: WAM S15917, height 13.5 mm; A, exterior of I.V., B, interior of r.v., C, exterior of r.v., D, interior of I.V.; E-F, N.W. of Bunbury, WA: WAM S84345, height $10.3 \mathrm{~mm}$. E exterior of I.v., F interior of I.v.

G, H, I, J, K, L, M, N, O, P, Q, R, S, T, Frigidocardium torresi (E.A. Smith, 1885). G-L, N.W. of Port Hedland, WA: WAM S15902. G-H, length $5.0 \mathrm{~mm}$, G, exterior of r.v., H, interior of r.v.; l-J, length $5.3 \mathrm{~mm}$, I, exterior of I.V., J, interior of I.v.; K-L, length $4.8 \mathrm{~mm}, \mathrm{~K}$, exterior of I.v., L, interior of I.v.; M-T, S. of Papua, Indonesia: NHMUK 1887.2.9.2736, three syntypes. M-O, length $4.2 \mathrm{~mm}, \mathrm{M}$, exterior of I.v., $\mathrm{N}$, interior of I.v., O, ventral slope of I.V., P-Q, length $3.7 \mathrm{~mm}$ (defect), P, exterior of r.V., $\mathrm{Q}$, interior of r.v., R-T, length $4.1 \mathrm{~mm}$, R, exterior of r.V., $S$, interior of r.v., T, hinge of r.v.

U, V, W, X, Frigidocardium iris Huber \& ter Poorten, 2007. U, N.N.W. of Anchor Island, WA: WAM S15896, length $24.6 \mathrm{~mm}$, exterior of I.V.; V-X, Cabulan Island, Philippines: WAM S15898, paratype, height 21.0

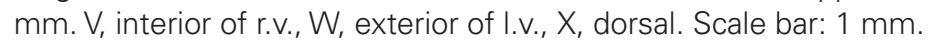


2005, Stn SS1005/146 (WAM S29309, 2 s.v.); Ningaloo Marine Park, $22^{\circ} 5^{\prime} 24^{\prime \prime S}, 113^{\circ} 49^{\prime} 37^{\prime \prime E}$ to $22^{\circ} 5^{\prime} 25^{\prime \prime S}$, 1134'ㄹ'"E, 83-85 m, 10.02.2008. Leg. S.M. SlackSmith \& M.P. Salotti, AIMS RV 'Solander' Cruise, Stn RVS4545-D130 (WAM S43512, 1 s.v.); Ningaloo Marine Park, off Osprey Sanctuary Zone, $22^{\circ} 17.455^{\prime} \mathrm{S}$, $113^{\circ} 45.237^{\prime} \mathrm{E}$ to $22^{\circ} 17.139^{\prime} \mathrm{S}, 113^{\circ} 45.361^{\prime} \mathrm{E}, 88-91 \mathrm{~m}$, 27.04.2006. Leg. M.P. Salotti, AIMS-WAM RV 'Cape Ferguson' Ningaloo Survey I, Stn CF4010\&11/2006/ D008 (WAM S78253, 1 s.v.); Ningaloo Marine Park, $22^{\circ} 27^{\prime} 60^{\prime \prime S}, 113^{\circ} 29^{\prime} 12^{\prime \prime E}$ to $22^{\circ} 27^{\prime} 1 " \mathrm{~S}, 113^{\circ} 38^{\prime} 11^{\prime \prime E}$, 102-110 m, 09.02.2008. Leg. S.M. Slack-Smith, AIMS RV 'Solander' Cruise, Stn RVS4545-D129 (WAM S43496, 1 s.v.); Off Point Cloates, $22.8487^{\circ} \mathrm{S}, 113.5110^{\circ} \mathrm{E}$ to $22.8583^{\circ} \mathrm{S}, 113.5140^{\circ} \mathrm{E}, 100 \mathrm{~m}, 09.12 .2005$. Leg. S.M. Slack-Smith, \& M.P. Salotti, CSIRO RV 'Southern Surveyor' Cruise SS1005 Nov/Dec 2005, Stn SS1005/135 (WAM S29390, 2 p.v., A); Off Point Cloates, $22.8504^{\circ} \mathrm{S}$, $113.5110^{\circ} \mathrm{E}$ to $22.8554^{\circ} \mathrm{S}, 113.5130^{\circ} \mathrm{E}, 100 \mathrm{~m}, 09.12 .2005$. Leg. S.M. Slack-Smith, \& M.P. Salotti, CSIRO RV 'Southern Surveyor' Cruise SS1005 Nov/Dec 2005, Stn SS1005/139 (WAM S29392, 1 s.v.); W. of Point Cloates, $22^{\circ} 52^{\prime} \mathrm{S}, 113^{\circ} 29^{\prime} \mathrm{E}, 73 \mathrm{fms}(133 \mathrm{~m}), 06.10 .1963$. CSIRO HMAS 'Diamantina' Cruise II 1963, Stn DM6/128/63 (WAM S15917, ex 209-67, 2 p.v.); Leeuwin-Naturaliste, N.W. of Bunbury, $33^{\circ} 00^{\prime} \mathrm{S}, 114^{\circ} 52^{\prime} \mathrm{E}, 115-122 \mathrm{~m}$, 17.02.1964. Leg. CSIRO Staff (WAM S84345, 1 s.v.).

\section{DESCRIPTION}

Shell relatively large (H 25-30 mm), rather fragile, inflated, ovate-quadrangular and slightly inequilateral. Length and height about equal. Ribbing structure homogeneous, with between 130-145 radial ribs covering the whole surface, all sculptured on anterior side with a row of erect but delicate spines of distinctly alternating strength, becoming slightly spatulate anteriorly and coarser posteriorly; commarginal sculpture of rib interstices usually inconspicuous. Lunular heart well defined, elevated, orange coloured and rather broad, variably rounded to flattened on top. Lunular area finely sculptured but with no clear border; lunular margin straight. Shell exterior white and often radially and commarginally streaked orange, lunule orange, umbo mostly yellowish. Entire shell occasionally pure lemon yellow, interior white with pinkish posterior zone and yellowish umbonal cavity.

\section{DISTRIBUTION AND ECOLOGY}

Mainly found in northern WA near the edge of the continental shelf (Figure 17A). Depth range of live taken samples 78-100 metres. Widely distributed in the Central IWP.

\section{REMARKS}

It has become evident that Wilson and Stevenson (1977) based their opinion of $F$. torresi on the incorrect assumption that the type material would be juvenile (Huber and ter Poorten 2007). This possibility was already taken into account by Smith (1885). As a consequence, Lamprell and Whitehead (1992: sp. 219) figured $F$. eos (a specimen from Philippines, Sulu Archipelago, WAM S78153, ex 99-67) under the same name. However, F. torresi is clearly differentiated by its lower rib number (75-90) versus 130-145 for eos (see ter Poorten 2009: table 7 for other differentiating characters). Frigidocardium is a tropical genus occurring in deep water, hence it is limited to the offshore waters of WA. Frigiocardium iris shows an almost identical WA distribution pattern, except for sample WAM S84345 (Figures 2E-F), which is by far the southernmost record of $F$. eos and also of the genus. As it is a CSIRO expedition sample, the locality is considered trustworthy. This record is consistent with other records from a range of taxa along this coastline highlighting the incidence of tropical vagrants pushing southward.

\section{Frigidocardium helios ter Poorten \& Poutiers, 2009}

\author{
Figures $3 \mathrm{~A}-\mathrm{H}$
}

Nemocardium (Microcardium) torresi (Smith, 1885) Wilson and Stevenson 1977: 65-66 [pars].

Frigidocardium helios ter Poorten \& Poutiers in ter Poorten, 2009: 64-65, pl. 18 figs 1-6, pl. 19 fig. 2, pl. 20 fig. 1.

Frigidocardium helios ter Poorten \& Poutiers in ter Poorten, 2009 — ter Poorten 2011: pl. 1105 fig. 1.

\section{MATERIAL EXAMINED}

Australia: Western Australia: Pilbara Offshore, Onslow, $7 \mathrm{mls}(11 \mathrm{~km}) \mathrm{N}$. of Long Island, off Onslow, $21^{\circ} 31^{\prime} \mathrm{S}, 114^{\circ} 40^{\prime} \mathrm{E}, 28 \mathrm{fms}(51 \mathrm{~m})$, fine sand and rubble, 17.06.1960. Western Australian Hawaiian Exped., hauls 9-11 (WAM S78145, ex 189-67, 1 s.v.); Ningaloo, Off Point Cloates, $22.8487^{\circ} \mathrm{S}, 113.5110^{\circ} \mathrm{E}, 100 \mathrm{~m}, 09.12 .2005$. Leg. S.M. Slack-Smith \& M.P. Salotti, CSIRO RV 'Southern Surveyor' Cruise SS1005 Nov/Dec 2005, Stn SS1005/135 (WAM S29441, 2 p.v., A).

\section{DESCRIPTION}

Shell relatively small (L 7-9.5 mm), thin, moderately inflated, ovate-quadrangular and slightly inequilateral. Length slightly exceeds height. Anterior and ventral margins rounded, posterior margin truncate, nearly straight. Ribbing structure homogeneous, with between 130-175 low radial riblets covering the whole surface and about 44-66 primary radial rows of tiny spines originating from the interstices. Spiny rows alternating with the remaining interstices that carry thin crossbars. Secondary sculptured rows restricted to antero-dorsal part, limited to 1-3 rows, if present at all. Lunular area finely sculptured, not sharply delimited, margin a little sinuous. Lunular heart small, broad and elevated. Shell exterior white, often vaguely radially and commarginally streaked orange with a reddish-orange stain near postero- 
dorsal margin; umbonal tip reddish, lunular area with a distinct yellow-orange hue; interior same colouration because of the translucency of the shell.

\section{DISTRIBUTION AND ECOLOGY}

WA records are from the north, with a single live taken sample from 100 meters depth and this species has a wide IWP distribution. Supplementary to the distribution given by ter Poorten (2009), additional material has become available from the Red Sea (ter Poorten and van Gemert 2016), N. Madagascar and Fiji (both MNHN, det. TP).

\section{REMARKS}

These represent the first Australian records of this recently described species. The MNHN holotype is figured herein for comparison (Figures 3C-D). Its former identification as $F$. torresi is indicative of the challenging taxonomy within the genus Frigidocardium (see also remarks under $F$. eos).

\section{Frigidocardium iris Huber \& ter Poorten, 2007}

Figures 2U-X, 17B

Nemocardium (Microcardium) exasperatum (Sowerby, 1838) - Wilson and Stevenson 1977: 67-68, pl. 4 figs 18 (= WAM S15889, paratype) 19 (= WAM S15898, paratype), text fig. 9 (not figs 14-17).

Frigidocardium exasperatum (Sowerby, 1838) Lamprell and Whitehead 1992: pl. 33 fig. 220 [Philippine specimen figured].

Frigidocardium iris Huber \& ter Poorten, 2007: 105107, pl. 1 figs 1-10, pl. 2 figs 7-10.

Frigidocardium iris Huber \& ter Poorten, 2007 - ter Poorten 2009: pl. 17 figs 5-7, pl. 20 fig. 5; Huber 2010: 307, fig.; ter Poorten 2011: pl. 1106 figs 4-7.

\section{MATERIAL EXAMINED}

Australia: Western Australia: Oceanic Shoals, E. of Cartier Reef, 11 nautical miles S. of Barracouta Shoal, Osborn Passage, $12^{\circ} 42.86^{\prime} \mathrm{S}, 123^{\circ} 57.98^{\prime} \mathrm{E}, 180 \mathrm{~m}$. Leg. R.S. Williams (NTM P.8600, 6 s.v.); North West Shelf, N. of Adele Island L28, $14.5615^{\circ} \mathrm{S}, 122.9062^{\circ} \mathrm{E}$ to $14.5502^{\circ} \mathrm{S}, 122.911^{\circ} \mathrm{E}, 135-165 \mathrm{~m}, 05.07 .2007$. Leg. M.P. Salotti, CSIRO RV 'Southern Surveyor' Cruise, Stn SS0507/162 (WAM S32878, 1 s.v.); S.E. of Mermaid Reef, $17.4872^{\circ} \mathrm{S}, 120.4606^{\circ} \mathrm{E}$ to $17.4954^{\circ} \mathrm{S}, 120.4679^{\circ} \mathrm{E}$, 184-187 m, 20.06.2007. Leg. C. Whisson \& O. Gomez, CSIRO RV 'Southern Surveyor' Cruise, Stn SS0507/091 (WAM S32889, 2 s.v.); S.E. of Imperieuse Reef L23, $18.4253^{\circ} \mathrm{S}, 120.0987^{\circ} \mathrm{E}$ to $18.4368^{\circ} \mathrm{S}, 120.1082^{\circ} \mathrm{E}$, 103-105 m, 19.06.2007. Leg. C. Whisson \& O. Gomez,
CSIRO RV 'Southern Surveyor' Cruise, Stn SS0507/085 (WAM S32888, 3 s.v.); 115 nautical miles N. of Port Hedland, $18^{\circ} 24^{\prime} \mathrm{S}, 118^{\circ} 31^{\prime} \mathrm{E}$ to $18^{\circ} 24^{\prime} \mathrm{S}, 118^{\circ} 29^{\prime} \mathrm{E}$, sand or mud, 154-156 m, 28.03.1982. Leg. L.M. Marsh, CSIRO FRV 'Soela' Cruise II, Stn SO2/82/08 (WAM S15899, 2 s.v.); 129 nautical miles N.E. of Cape Lambert, $18^{\circ} 42.8^{\prime} \mathrm{S}, 118^{\circ} 03.2^{\prime} \mathrm{E}$ to $18^{\circ} 39.6^{\prime} \mathrm{S}, 118^{\circ} 06.3^{\prime} \mathrm{E}$, limestone rubble and shells, 150-160 m, 18.08.1995. Leg. L.M. Marsh et al., AIMS Survey RV 'Lady Basten', Stn AIMS/95/LB5A (WAM S15925, 3 s.v.); 100 nautical miles N.W. of Port Hedland, $18^{\circ} 47^{\prime} \mathrm{S}, 17^{\circ} 58^{\prime} \mathrm{E}$, grey mud \& shell rubble, 154 m, 28.03.1982. Leg. L.M. Marsh, CSIRO FRV 'Soela' Cruise II, Stn SO2/82/10A (WAM S15905, 1 s.v.); 37 miles N.W. of Enderby Island, $20^{\circ} 07.1^{\prime} \mathrm{S}, 116^{\circ} 06.1^{\prime} \mathrm{E}$ to $20^{\circ} 06.0^{\prime} \mathrm{S}, 116^{\circ} 04.4^{\prime} \mathrm{E}$, shelly sand, 56-58 m, 29.09.1982. Leg. L.M. Marsh, \& M. Bezant, CSIRO FRV 'Soela' Cruise V, Stn SO5/82/24 (WAM S15910, 1 s.v.); Pilbara Offshore, 10-20 miles (32 km) N.N.W. of Anchor Island, Onslow, 2138'S, $115^{\circ} 07^{\prime} \mathrm{E}$, mud \& gravel, $65 \mathrm{fms}$ (119 m), 17.06.1960. Leg. B.R. Wilson, R. George \& L. Joll, Mariel King Hawaiian Exped. MV 'Davena' (WAM S15895, ex 248-67, 1 s.v.; WAM S15896, ex 292-67, 1 s.v.); Off Barrow Island, $21.0358^{\circ} \mathrm{S}, 114.888^{\circ} \mathrm{E}$ to $21.0332^{\circ} \mathrm{S}$, $114.8857^{\circ} \mathrm{E}, 90-100 \mathrm{~m}, 10.06 .2007$. Leg. C. Whisson, CSIRO RV 'Southern Surveyor' Cruise, Stn SS0507/008 (WAM S32862, 1 s.v.); Ningaloo, W. of North West Cape, $21^{\circ} 48^{\prime} \mathrm{S}, 113^{\circ} 56^{\prime} \mathrm{E}, 60-70 \mathrm{fms}(110-128 \mathrm{~m})$, 01.02.1964. CSIRO HMAS 'Diamatina' Cruise III, Stn DM1/124/64 (WAM S15894, ex 210-67, 1 s.v.); Ningaloo Marine Park, Mandu Creek, 22 ${ }^{\circ} 33^{\prime \prime S}, 113^{\circ} 47^{\prime} 37^{\prime \prime E}$ to 22॰8'35"S, 11347'36"E, 109-110 m, 18.08.2008. Leg. O.A. Gomez \& J. Colquhoun, AIMS-WAM RV 'Cape Ferguson' Ningaloo Survey IV, Stn SOL4769/2008/1017SL01 (WAM S43899, 1 s.v.); Ningaloo Marine Park, $22^{\circ} 14^{\prime} 55^{\prime \prime} \mathrm{S}, 113^{\circ} 45^{\prime} 26^{\prime \prime E}$ to $22^{\circ} 16^{\prime} 20^{\prime \prime S}, 113^{\circ} 45^{\prime} 11^{\prime \prime E}$, 100-104 m, 26.04.2006. Leg. M.P. Salotti, AIMSWAM RV 'Cape Ferguson' Ningaloo Survey I, Stn CF4010\&11/2006/D007 (WAM S78136, 1 s.v.); Ningaloo Marine Park, $22^{\circ} 15^{\prime} 46^{\prime \prime S}, 113^{\circ} 44^{\prime} 58^{\prime \prime E}$ to $22^{\circ} 15^{\prime} 37^{\prime \prime S}$, $113^{\circ} 45^{\prime} 1 " E, 115$ m, 27.04.2006. Leg. M.P. Salotti, AIMSWAM RV 'Cape Ferguson' Ningaloo Survey I, Stn CF4010\&11-D009 (WAM S78135, 1 s.v.); Undefined bioregion, 'Between Shark Bay and Onslow', 1966. Leg. W. \& W. Poole Bros (WAM S78143, 1 s.v.).

\section{DESCRIPTION}

Shell relatively large $(\mathrm{H} 25-28 \mathrm{~mm})$, rather thin, inflated, ovate-quadrangular and subequilateral. Length approximately equal to height. Ribbing structure homogeneous, with over 100 radial ribs covering the whole surface, of which between 30-40 bear finely upright spines, positioned on the sides and becoming slightly larger and more crowded posteriorly and spatulate to almost knobby anteriorly. Primary rib sculpture regularly alternating with row of tiny secondary spines, also positioned on the rib sides. Interstices with poorly developed cross-striae, sometimes 
lacking. Lunule well delimited and weakly sculptured, lunular heart well defined, forming a rounded ovate bulge of the dorsal margin. Exterior white, usually with red collars, commarginally arranged and more prominent towards the margins; sometimes almost all pinkish-red or white Interior white, umbonal cavity usually deep yellow. Lunular area generally deep orange-red.

\section{DISTRIBUTION AND ECOLOGY}

Presence in northern WA and Ningaloo well established and based on numerous records, often found near the edge of the continental shelf (Figure 17B) but exclusively consisting of loose valves (depth range 56-187 metres), mostly rather worn. Widely distributed in the Central IWP.

\section{REMARKS}

Huber and ter Poorten (2007) demonstrated that the supposed type locality of $F$. exasperatum (G.B. Sowerby II, 1839), 'Swan River' (Western Australia, Perth, Swan River), was erroneous and emended it to Taiwan. While $F$. exasperatum is restricted to southern JapanChina-Vietnam, F. iris ranges from Philippines through to Indonesia and along to the northern coast of WA, thus the two sister species exhibit a classic parapatric distribution.

\section{Frigidocardium torresi (E.A. Smith, 1885)}

Figures $2 \mathrm{G}-\mathrm{T}$, $17 \mathrm{C}$

Cardium (Fragum) torresi E.A. Smith, 1885: 164-165, pl. 8 figs $4,4 a-b$.

Frigidocardium torresi (E.A. Smith, 1885) - ter Poorten 2009: pl. 17 figs 11-15, pl. 19 fig. 3, pl. 20 fig. 6; Huber 2010: 307, fig.; ter Poorten 2011: pl. 1106 figs $1-3$.

Not: Nemocardium (Microcardium) torresi (Smith, 1885) - Wilson and Stevenson 1977: 65-66, pl. 4 figs 20-22, text fig. 8 (=F. eos).

Not: Frigidocardium torresi (Smith, 1885) - Lamprell and Whitehead 1992: pl. 33 fig. 219 (=F. eos).

\section{MATERIAL EXAMINED}

Indonesia: S. of Papua, N. of Gulf of Carpentaria, $09^{\circ} 59^{\prime} \mathrm{S}, 139^{\circ} 42^{\prime} \mathrm{E}, 28 \mathrm{fms}$. [51 m], 10.09.1874. Challenger Exp. stn. 188 (NHMUK 1887.2.9.2736, three syntypes, all s.v.).

Australia: Northern Territory: Oceanic Shoals, southern Timor Sea, NW. corner of Melville Island, approx. $50 \mathrm{~km}$ due W. of Cape Van Diemen, southern Van Diemen Rise, $11^{\circ} 3.262^{\prime} \mathrm{S}, 129^{\circ} 52.344^{\prime} \mathrm{E}, 76.2 \mathrm{~m}$, 24.08.2010. Leg. B. Alvarez (NTM P.52732, 1 p.v., A); N. of eastern section of Jospeh Bonaparte Gulf, Melville Island, approx. $125 \mathrm{~km}$ N.W. of Cape Van Diemen, northern Van Diemen Rise, $10^{\circ} 26.956$ 'S, $129^{\circ} 28.966^{\prime} \mathrm{E}$, 134.9 m, 18.08.2010. Leg. B. Alvarez (NTM P.52468, 1 p.v.); northern Van Diemen Rise, $10^{\circ} 33.086$ 'S, $129^{\circ} 28.700^{\prime} \mathrm{E}, 67.7 \mathrm{~m}, 20.08 .2010$. Leg. B. Alvarez (NTM P.49938, 1 p.v.).

Australia: Western Australia: Canning, W. of Broome, $17^{\circ} 58^{\prime} \mathrm{S}, 122^{\circ} 14^{\prime} \mathrm{E}, 90 \mathrm{~m}, 21.12 .1969$. Leg. K. Ozawa, Tokyo Uni of Fisheries Exped. FV 'Umataka Maru', Stn UMD6927 (WAM S57167, 3 s.v.); Oceanic Shoals, Rowley Shoals, Clerke Reef, $17^{\circ} 20^{\prime} \mathrm{S}, 19^{\circ} 10^{\prime} \mathrm{E}$, 266 m, 20.12.1969. Leg. K. Ozawa, Tokyo Uni of Fisheries Exped. FV 'Umitaka Maru', Stn UMD/69/26 (WAM S15913, 1 s.v. WAM S15915, 2 s.v.); North West Shelf, 86 nautical miles N.N.W. of Port Hedland, $18^{\circ} 54^{\prime} \mathrm{S}, 118^{\circ} 22^{\prime} \mathrm{E}$ to $18^{\circ} 52^{\prime} \mathrm{S}, 118^{\circ} 21^{\prime} \mathrm{E}$, from white gorgonians, $102 \mathrm{~m}, 27.03 .1982$. Leg. L.M. Marsh, CSIRO FRV 'Soela' Cruise II, Stn SO2/82/05 (WAM S15907, 1 s.v.); 100 nautical miles N.W. of Port Hedland, $18^{\circ} 47^{\prime S}$, $117^{\circ} 58^{\prime} \mathrm{E}$, grey mud and shell rubble, $154 \mathrm{~m}, 28.03 .1982$. Leg. L.M. Marsh, CSIRO FRV 'Soela' Cruise II, Stn SO2/82/10A (WAM S15900, 1 s.v.; WAM S15902, 6 s.v.); 109 nautical miles N.W. of Port Hedland, $18^{\circ} 56^{\prime}$ S, $117^{\circ} 21^{\prime} \mathrm{E}$ to $18^{\circ} 57^{\prime} \mathrm{S}, 117^{\circ} 19^{\prime} \mathrm{E}$, limestone rocks and mud, 201-202 m, 14.04.1982, Leg. L.M. Marsh, CSIRO FRV 'Soela' Cruise II, Stn SO2/82/048 (WAM S15901, 3 s.v.); N.N.E. of Dampier Archipelago, $19^{\circ} 23^{\prime}$ S, $117^{\circ} 21^{\prime} \mathrm{E}$ to $19^{\circ} 23^{\prime} \mathrm{S}, 117^{\circ} 23^{\prime} \mathrm{E}, 101-102 \mathrm{~m}, 11.03 .1981$. Leg. N. Sinclair, 'Hai Kung' Survey (WAM S78287, 1 s.v.).

\section{DESCRIPTION}

Shell relatively small (L 5-9 $\mathrm{mm}$ ), thickness rather variable, well inflated, quadrangular, with truncated posterior margin, sometimes slightly concave. Length usually slightly exceeds height. Sculpture homogeneous, with between 75-90 radial ribs covering the whole surface; ribs rather square-shaped and as wide as the interstices in median area, becoming lower and rounder towards dorsal margin. Between 22-32 radial rows of blunt spines or spoon-shaped projections, arising from the interstices. Secondary radial sculpture absent or confined to very few interstices. Radial spiny sculpture regularly alternating with interstices that carry well developed crossbars, somewhat differing in strength among specimens. Lunular heart smooth, rather long and narrow; lunular area unsculptured, not sharply bordered. Exterior colour white with reddish-orange umbonal tip, interior occasionally with similarly coloured umbonal cavity.

\section{DISTRIBUTION AND ECOLOGY}

The presence of $F$. torresi in WA is confirmed by several records, mainly off the northern coast at the edge of the continental shelf, between Dampier and Broome (Figure 17C). In WA it has been found in a depth range of 90-266 metres, based on single valves. The only live taken specimen is from NT, depth 76 metres. Not reported from QLD, but given the type locality (South of Papua) records are to be expected from northern QLD. 


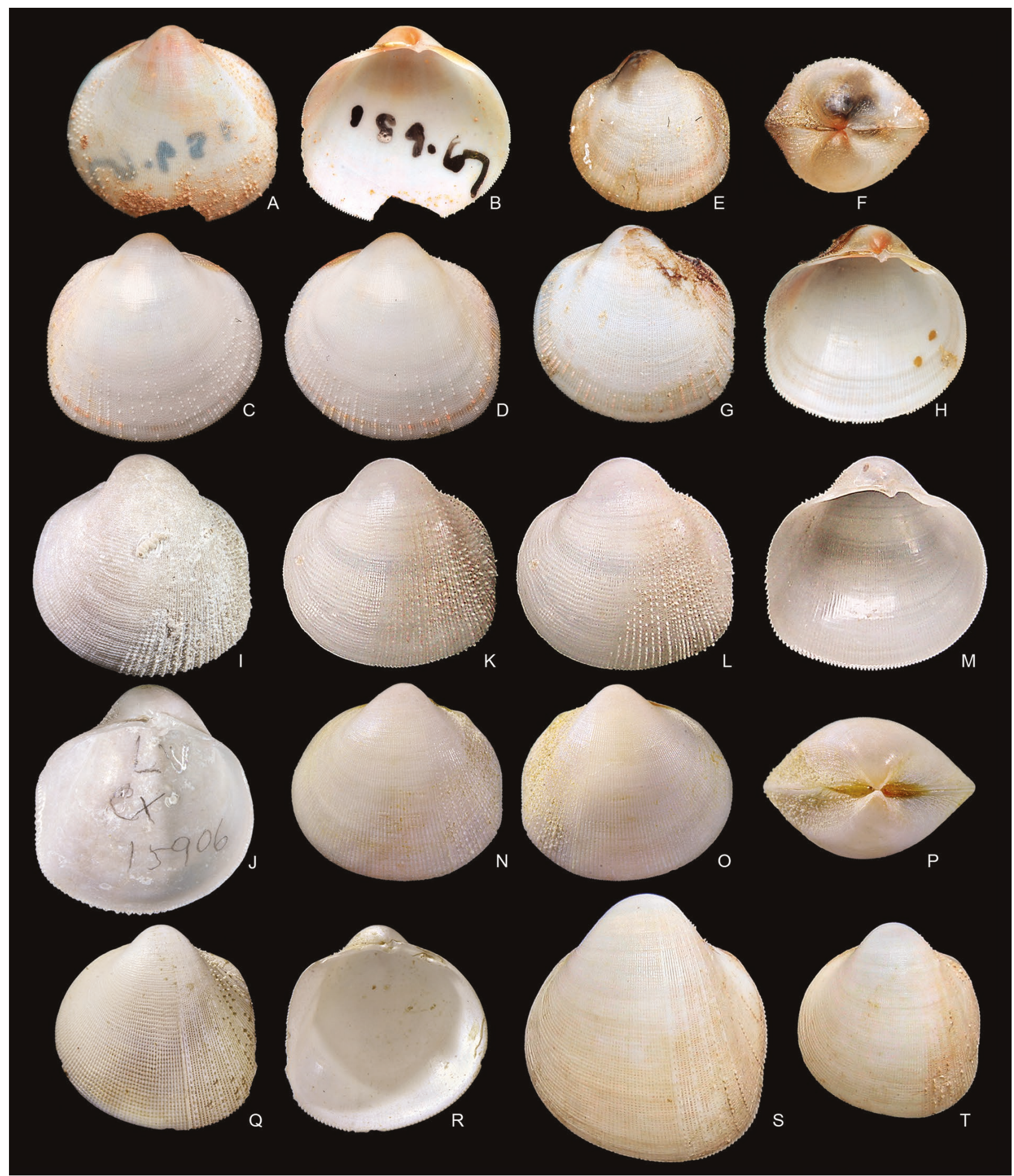

FIGURE 3 A, B, C, D, E, F, G, H, Frigidocardium helios ter Poorten \& Poutiers, 2009. A-B, off Onslow, WA: WAM S78145, length $6.8 \mathrm{~mm}$ (defect). A, exterior of I.v., B, interior of I.v.; C-D, S.E. corner of Santo, Vanuatu: MNHN IM2007-30161, holotype, length $7.3 \mathrm{~mm}$. C, exterior of I.v., D exterior of r.v.; E-H, Aru, Indonesia: WAM S78140. E-F, length $5.1 \mathrm{~mm}$, E, exterior of I.v., F, dorsal, G-H, length $6.6 \mathrm{~mm}$, G, exterior of I.v., H, interior of I.V.

I, J, K, L M, Microcardium scabrosum sp. nov. I-J, N.W. of Port Hedland, WA: WAM S15906, holotype, height $11.3 \mathrm{~mm}$; I exterior of I.v., J interior of I.v.; K-M, off North West Cape, WA: WAM S35202, length 9.8 mm. $\mathrm{K}-\mathrm{L}$, exterior of I.V. under different light conditions, $\mathrm{M}$ interior of I.V.

N, O, P, Pratulum thetidis (Hedley, 1902). Off Perth, WA: WAM S29300, length $8.5 \mathrm{~mm}$. N, exterior of r.v., O, exterior of I.V., P, dorsal.

Q, R, S, T, Microcardium sakuraii (Habe, 1961). Q-R, W.N.W. of Lacepede Islands, WA: WAM S57161, height $10.8 \mathrm{~mm}, \mathrm{Q}$, exterior of I.V., R, interior of I.v.; S-T, off North West Cape, WA: TP 2044. S, height 16.5 mm, exterior of I.V., T, height $10.9 \mathrm{~mm}$, exterior of I.V. $6 \mathrm{~mm}$. 

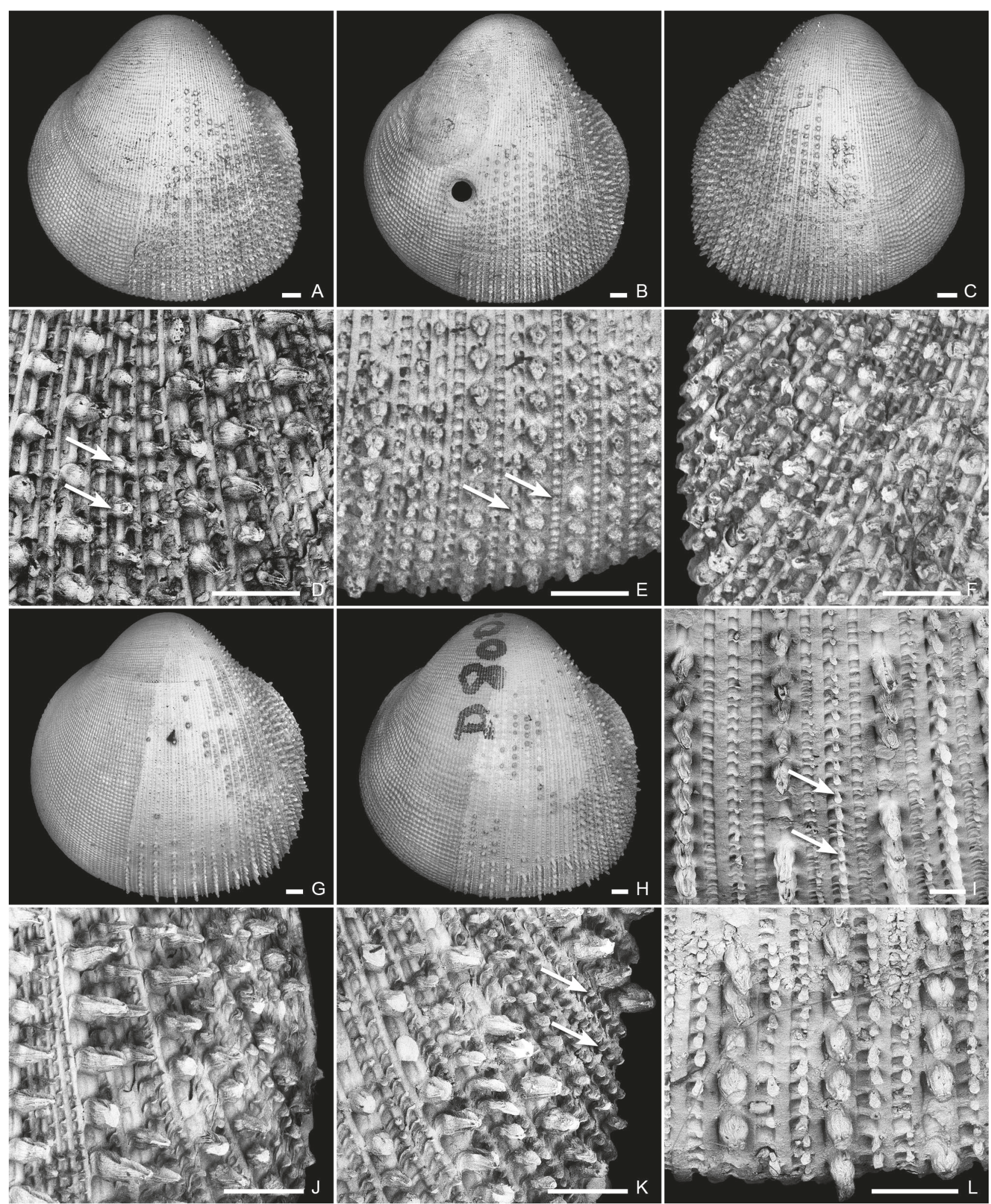

FIGURE $4 \quad$ A, B, C, D, E, F, Microcardium scabrosum sp. nov. A, C,E-F, N. of Croker Island, NT: AMS C145.749, paratypes; A exterior of I.V., length $9.0 \mathrm{~mm}, \mathrm{C}$, exterior of r.v., length $9.1 \mathrm{~mm}$, E, anterior part of posterior sculpture, F, posterior slope; B,D, N. of Goulburn Island, NT: AMS C145.746, paratype, length 11.2 mm. B, exterior of I.V., D, posterior slope.

G, H, I, J, K, L, Microcardium gilchristi (G.B. Sowerby III, 1904). G, I-K, SE of Port Durnford, Zululand: NM E4595, length $12.0 \mathrm{~mm}$; G, exterior of r.v., I, anterior part of posterior sculpture, J-K, posterior slope; H,L, off Point Durnford, Zululand: NM D8005, length 11.4 mm. H, exterior of r.v., L, medial ventral margin. Scale bars: $0.5 \mathrm{~mm}$. 


\section{REMARKS}

All Wilson and Stevenson (1977) F. torresi records proved to represent $F$. eos (see also remarks under that species) or $F$. helios due to misinterpretation of the type material. The three poorly preserved NHMUK 1887.2.9.2736 syntypes (severely affected by Byne's disease) are figured herein for comparison (Figures 2M-T).

\section{Genus Microcardium Keen, 1937}

Microcardium Thiele, 1934: 878. (Not available, no type species designation — ICZN 1999: Art. 42.3.2).

Microcardium Keen, 1937: 14-15. Type species by original designation: Cardium (Fulvia) peramabilis Dall, 1881; Recent, $23^{\circ} 13^{\prime} \mathrm{N}, 89^{\circ} 16^{\prime} \mathrm{W}$, off Yucatan, Mexico, $154 \mathrm{~m}$.

Decussicardium Fischer-Piette, 1977: 94. Type species by monotypy: Cardium gilchristi G.B. Sowerby III, 1904; Recent, Algoa Bay, South Africa, 15 fms [27 $\mathrm{m}$. (Not available, no description and type species designation - ICZN 1999: Art. 13.1, 13.3).

Tobarum Noda, 1988: 74. Type species by original designation: Frigidcardium [sic! err. pro Frigidocardium] (Tobarum) tobaruensis Noda, 1988; Upper Pliocene, Shinzato Formation, Okinawa, Japan.

\section{Microcardium sakuraii (Habe, 1961)}

Figures 30-T, 17D

Nemocardium (Microcardium) sakuraii Habe, 1961: 152, 155-156, fig. 9.

Microcardium sakuraii (Habe, 1961) - ter Poorten 2009: pl. 20 fig. 7, pl. 21 figs 1-2; ter Poorten 2011: pl. 1113 figs $1-2$.

Microcardium tenuilamellosum J.-M. Poutiers, 1981 Huber 2010: 308, fig.

\section{MATERIAL EXAMINED}

Australia: Western Australia: Oceanic Shoals, N. of Browse Island, $14^{\circ} 06^{\prime} \mathrm{S}, 123^{\circ} 33^{\prime} \mathrm{E}$ (Egaz), $380 \mathrm{~m}$, Stn UMD/69/30, leg. K. Ozawa, 23.12.1969 (WAM S57142, 1 s.v.); N.W. of Augustus Island, $13^{\circ} 33.3^{\prime} \mathrm{S}, 122^{\circ} 54.5^{\prime} \mathrm{E}$ to $13^{\circ} 34.3^{\prime} \mathrm{S}, 122^{\circ} 52.3^{\prime} \mathrm{E}, 390-394 \mathrm{~m}, 14.02 .1984$. Leg. S.M. Slack-Smith, CSIRO FRV 'Soela' Cruise VI, Stn SO1/84/073 (WAM S57163, 1 s.v.); N.W. of Collier Bay, $14^{\circ} 07.5^{\prime} \mathrm{S}, 122^{\circ} 29.4^{\prime} \mathrm{E}$ to $14^{\circ} 06.8^{\prime} \mathrm{S}, 122^{\circ} 31.7^{\prime} \mathrm{E}, 406-$ 408 m, 13.02.1984. Leg. S.M. Slack-Smith, CSIRO FRV 'Soela' Cruise VI, Stn SO1/84/072 (WAM S57162, 1 s.v.); W.N.W. of Lacepede Islands, $15^{\circ} 51.2^{\prime} \mathrm{S}, 120^{\circ} 44.3^{\prime} \mathrm{E}$ to $15^{\circ} 49.3^{\prime} \mathrm{S}, 120^{\circ} 45.3^{\prime} \mathrm{E}, 348-350 \mathrm{~m}, 10.02 .1984$. Leg. S.M. Slack-Smith, CSIRO FRV 'Soela' Cruise VI, Stn SO1/84/054 (WAM S57161, 2 s.v.); Rowley Shoals, off Mermaid Reef L24 east, $17.0473^{\circ} \mathrm{S}, 119.6614^{\circ} \mathrm{E}$ to $17.0618^{\circ} \mathrm{S}, 119.6893^{\circ} \mathrm{E}, 424-456 \mathrm{~m}, 18.06 .2007$. Leg. C. Whisson \& O. Gomez, CSIRO RV 'Southern Surveyor' Cruise, Stn SS0507/077 (WAM S32884, 1 s.v.); off Mermaid Reef L24 south, $17.1972^{\circ} \mathrm{S}, 119.5802^{\circ} \mathrm{E}$ to 17.2061 ${ }^{\circ} \mathrm{S}, 119.5855^{\circ} \mathrm{E}, 435-438 \mathrm{~m}, 18.06 .2007$. Leg. C. Whisson \& O. Gomez, CSIRO RV 'Southern Surveyor' Cruise, Stn SS0507/079 (WAM S32885, 9 s.v.); off Mermaid Reef L24 north, $17.0182^{\circ} \mathrm{S}, 119.591^{\circ} \mathrm{E}$ to $17.0302^{\circ} \mathrm{S}, 119.5833^{\circ} \mathrm{E}, 440-451 \mathrm{~m}, 18.06 .2007$. Leg. C. Whisson \& O. Gomez, CSIRO RV 'Southern Surveyor' Cruise, Stn SS0507/080 (WAM S32886, 4 s.v.); Rowley Shoals, off Mermaid Reef, in sand and mud, by Scampi trawler, 400-450 m (TP 3567, 2 s.v.); Rowley Shoals, on sandy mud, 400-450 m (TP 3770, 3 s.v.); Undefined bioregion,'off Exmouth, North West Cape', trawled offshore on sand and mud, 400-500 m (TP 2044, 2 p.v.).

\section{DESCRIPTION}

Shell rather small (L up to $18 \mathrm{~mm}$ ), rather thin, length approximately equal to height, rounded and inflated, nearly equilateral. Margins rounded, posterior margin straight or slightly concave. Inner margins finely crenulated. Between 125-145 radial riblets. Outer sculpture heterogeneous, divided into two markedly distinct sculptural zones. Anterior zone covering 60$65 \%$ of the shell, with tiny reticulate sculpture forming a pattern of undulating concentric ridges, stronger towards anterior margin. Posterior zone covering $35-40 \%$ of the shell, with barred sculpture, bearing well defined cross-bars in the interstices, each third to fifth interstice carrying small but erect, blunt spines; remainder unsculptured or occasionally carrying minute spinelets. Sculpture often becoming more laminate towards postero-dorsal margin. Demarcation line dividing the two zones directed obliquely in juveniles; and running parallel with the rib during subsequent ontogeny. Lunular heart mostly rather poorly developed and elevated, vaguely delimitated. Exterior and interior entirely white.

\section{DISTRIBUTION AND ECOLOGY}

Like its congeners, $M$. sakuraii is a deep water species found exclusively at the outer edge of the northern continental shelf down to a depth of at least 456 metres in WA (Figure 17D). Occurrence in WA was first reported by ter Poorten (2009). No records are known from NT or QLD. It is widely distributed in the Central IWP.

\section{REMARKS}

The deepest live-taken specimen was collected from 487-541 metres depth, Solomon Islands (MNHNIM-2007-32245). 


\section{Microcardium scabrosum sp. nov. Poutiers}

Figures 3I-M, 4A-F, 17E

urn:Isid:zoobank.org:act:421C3235-40AC-4DE0-A5900292FA91FCF5

Microcardium sp. A Poutiers, 1992: 142, fig. 2k.

Microcardium gilchristi (Sowerby, 1904) - [pars] ter Poorten 2005: 9.

\section{MATERIAL EXAMINED}

\section{Holotype}

Australia: Western Australia: North West Shelf, 100 nautical miles N.W. of Port Hedland, $18^{\circ} 47^{\prime} \mathrm{S}, 117^{\circ} 58^{\prime} \mathrm{E}$, 154 m, 28.03.1982, Leg. L.M. Marsh, CSIRO FRV 'Soela' Cruise II 1982, Stn. SO2/82/10A (WAM S15906, 1 s.v.).

\section{Paratypes}

Indonesia: Arafura Sea, $320 \mathrm{~km} \mathrm{~N}$. of Goulburn Island, $08^{\circ} 39^{\prime} \mathrm{S}, 133^{\circ} 34^{\prime} \mathrm{E}$, sand, silt and clay, $192 \mathrm{~m}$, 01.11.1969, Leg. P.H. Colman, MV 'San Pedro Sound' (BMR P69-1076 - AMS C145.746, 1 s.v., paratype).

Australia: Northern Territory: 100 miles N. of Croker Island, 09³0'S, 132 ${ }^{\circ} 34^{\prime} \mathrm{E}, 124 \mathrm{~m}, 09.11 .1969$, Leg. P.H. Colman, MV 'San Pedro Sound' (AMS C145.749, 6 s.v., paratypes; MNHN-IM-2000-32636, 2 S.V., paratypes).

Australia: Western Australia: North West Shelf, 100 nautical miles N.W. of Port Hedland, $18^{\circ} 47^{\prime} \mathrm{S}, 117^{\circ} 58^{\prime} \mathrm{E}$, 154 m, 28.03.1982, Leg. L.M. Marsh, CSIRO FRV 'Soela' Cruise II 1982, Stn. SO2/82/10A; WAM S99044, 1 s.v., paratype; WAM S99045, 5 s.v.); off North West Cape, on N.W. Shelf slope, $21^{\circ} 32.083^{\prime} \mathrm{S}, 114^{\circ} 07.53^{\prime} \mathrm{E}$ to $21^{\circ} 32.1866^{\prime} \mathrm{S}, 114^{\circ} 08.115^{\prime} \mathrm{E}, 190 \mathrm{~m}, 25.03 .2002$. Stn 15 , Leg. J. Fromont, L.M. Marsh \& P. Alderslade (WAM S35202, 1 s.V., paratype).

\section{Other material}

Indonesia: Arafura Sea, Arnhem Land, $365 \mathrm{~km} \mathrm{~N}$. of Milingimbi Island, $08^{\circ} 48^{\prime} \mathrm{S}, 1^{134^{\circ}} 58^{\prime} \mathrm{E}$, clayey-sand, 100 m, 18.10.1969, Leg. P.H. Colman, MV 'San Pedro Sound' (BMR 985 - AMS C145.742, 1 s.v.); 420 km N. of Melville Island, $08^{\circ} 18^{\prime} \mathrm{S}, 134^{\circ} 11^{\prime} \mathrm{E}$, sand, $141 \mathrm{~m}$, 03.11.1969, Leg. P.H. Colman , MV 'San Pedro Sound' (BMR 1091 - AMS C145.743, 2 s.v.); 210 miles N. of Crocker Island, $08^{\circ} 18^{\prime} \mathrm{S}, 133^{\circ} 58^{\prime} \mathrm{E}$, sand-silt-clay, $132 \mathrm{~m}$, 03.11.1969, Leg. P.H. Colman, MV 'San Pedro Sound' (AMS C145.747, 38 s.v.).

Australia: Northern Territory: Arafura Sea, $230 \mathrm{~km}$ N. of Goulburn Island, $09^{\circ} 18^{\prime} \mathrm{S}, 133^{\circ} 38^{\prime} \mathrm{E}$, clayey sand, 135 m, 01.11.1969, Leg. P.H. Colman, MV 'San Pedro Sound' (BMR P69-1073 - AMS C145.745, 3 s.v.); 320 $\mathrm{km} \mathrm{N}$. of Goulburn Island, $08^{\circ} 39^{\prime} \mathrm{S}, 133^{\circ} 34^{\prime} \mathrm{E}$, sand, silt and clay, 192 m, 01.11.1969, Leg. P.H. Colman, MV 'San Pedro Sound' (BMR P69-1076 - AMS C145.746, 1 s.v.); 100 miles N. of Croker Island, $09^{\circ} 30^{\prime} \mathrm{S}, 132^{\circ} 34^{\prime} \mathrm{E}$,
124 m, 09.11.1969, Leg. P.H. Colman, MV 'San Pedro Sound' (AMS C145.749, 30 s.v.); 205 km N. of Croker Island, 09 $07^{\circ} \mathrm{S}, 132^{\circ} 33^{\prime} \mathrm{E}$, clayey-sand, $218 \mathrm{~m}, 09.11 .1969$, Leg. P.H. Colman, MV 'San Pedro Sound' (BMR P691146 - AMS C145.741, 1 s.v.); Oceanic Shoals, 100 miles N. of Melville Island, $09^{\circ} 34^{\prime} \mathrm{S}, 131^{\circ} 22^{\prime} \mathrm{E}, 135 \mathrm{~m}$, 15.11.1969, Leg. P.H. Colman, MV 'San Pedro Sound' (AMS C145.748, 7 s.v.); S. of Tanimbar Islands, 09³7'S, 131 ${ }^{\circ} 02 ' E, 199-201$ m, 04.11.1991, KARUBAR Exped. Stn DW80, NO 'Baruna Jaya 1' (MNHN-IM-2014-6066, 23 s.v.); $150 \mathrm{~km} \mathrm{N.W.} \mathrm{of} \mathrm{Melville} \mathrm{Island,} 09^{\circ} 53^{\prime} \mathrm{S}, 130^{\circ} 02^{\prime} \mathrm{E}$, sand, 205 m, 05.12.1969, Leg. P.H. Colman, MV 'San Pedro Sound' (BMR 1220 — AMS C145.744, 1 s.v.).

Australia: Western Australia: North West Shelf, 100 nautical miles N.W. of Port Hedland, $18^{\circ} 47^{\prime} \mathrm{S}, 117^{\circ} 58^{\prime} \mathrm{E}$, 154 m, 28.03.1982, Leg. L.M. Marsh, CSIRO FRV 'Soela' Cruise II 1982, Stn. SO2/82/10A (WAM S15906, 6 s.v.); Ningaloo, off North West Cape, on N.W. Shelf slope, $21^{\circ} 32.083^{\prime} \mathrm{S}, 114^{\circ} 07.53^{\prime} \mathrm{E}$ to $21^{\circ} 32.186^{\prime} \mathrm{S}, 14^{\circ} 08.115^{\prime} \mathrm{E}$, 190 m, 25.03.2002. Stn 15, Leg. J. Fromont, L.M. Marsh \& P. Alderslade (WAM S35202, 1 s.v.); off Ningaloo (South), $22.0795^{\circ} \mathrm{S}, 113.7960^{\circ} \mathrm{E}$ to $22.0873^{\circ} \mathrm{S}, 113.7940^{\circ} \mathrm{E}$ [22 $04.77^{\prime} \mathrm{S}, 113^{\circ} 47.76^{\prime} \mathrm{E}$ to $\left.22^{\circ} 05.24^{\prime} \mathrm{S}, 113^{\circ} 47.64^{\prime} \mathrm{E}\right], 201-$ 206 m, 10.12.2005, Leg. S.M. Slack-Smith, \& M.P. Salotti, CSIRO RV 'Southern Surveyor' Cruise SS1005 Nov/Dec 2005, Stn SS1005/146 (WAM S29448, 1 s.v.).

\section{DESCRIPTION}

Shell equivalve, inflated, moderately thin, subquadrate ovate in shape, usually nearly as high as long, rather small for the genus (up to about $11.9 \mathrm{~mm}$ long). Umbones moderately protruding, prosogyrate, usually positioned just anterior to mid-length of shell; in a few specimens, postumbonal side of valves sometimes tending to be a little drawn out posteriorly, giving the shell a slightly more inequilateral shape. Outline roughly rounded anteriorly and ventrally, somewhat truncate posteriorly.

Sculpture of the outer surface heterogeneous and divided into two markedly different sculptural zones. Total rib number about 110-130 (with about 55-65 ribs in both anterior and posterior zones at adult stages).

Anterior zone with a reticulate sculpture of low, smooth rounded ribs, becoming slightly nodulous where they cross irregularly sinuous and approximately concentric, branched or interrupted fine ridges. Concentric elements tending to be more apparent anteriorly whereas the radial elements become less pronounced. Antero-dorsal margin bevelled and thickened just anterior to umbo, reflected over the corresponding part of the outer shell surface, forming a short and well defined lunular heart, minutely ridged and flattened on top. Lunular sector smooth (apart from growth lines), not clearly demarcated from the surrounding surface, and roughly extending to the level of the anterior lateral teeth.

Posterior sculptural area mainly composed of well developed radial ribs, transverse interstitial bars and numerous spines or tubercles giving this area a distinctly 
scabrous aspect. Radial ribs squarish in cross section, as wide as the interstices, the latter becoming a little wider on the posterior slope. Every second to third interstice sculptured with a row of distantly placed, erect, blunt and dorsally notched stout spines occupying the whole width of interstice. Other interstices with well developed crossbars nearly as high as adjacent ribs and numerous small tubercles arising from the posterior ends of crossbars and encroaching upon the anterior side of the adjacent ribs. Radial ribs disappearing toward the postero-dorsal margin of valves which is only sculptured with a few radial rows of spiny tubercles alternatively stronger and smaller; 2 or 3 rows of smaller tubercles usually present between 2 successive rows of larger spines, sometimes intercalated with minute granules. The demarcation line between the anterior and posterior zones displays oblique to radial ribbing extending anteriorly on the ventral margin to at least $3 / 5$ of the adult shell length.

Hinge somewhat arched, with two unequal cardinal teeth in each valve, the more ventral cardinal rather large, prominent and curved, the more dorsal forming a small conical tubercle; cardinal teeth joined by a saddle in the right valve, but separated by a deep socket in the left valve. Posterior lateral teeth farther to cardinals than anterior laterals; left valve with single posterior lateral and single anterior submarginal lateral; right valve with single submarginal posterior and paired anterior laterals separated by a deep socket, with dorsalmost anterior lateral much reduced.

Internal margins with fine crenulations in accordance with the outer radial sculpture, disappearing toward the anterior and posterior ends of the dorsal margin. Protruding elements of these crenulations correspond respectively with radial ribs in the posterior sculptural area of each valve, and with rib interstices in the anterior area.

Exterior and interior of the shell entirely white.

\section{DISTRIBUTION AND ECOLOGY}

This species appears to be confined to northwestern Australia, in the Arafura Sea (NT and southern tip of Indonesia) and north of WA (Figure 17E). It is presently known from deep water at the Sahul Shelf edge (depth range 100-218 m) and so far only known from single valves.

\section{REMARKS}

This species is characterised by its relatively wide posterior sculptural area, extending to more than $1 / 2$ of the shell length and by the demarcation line between anterior and posterior sculptural areas, featuring markedly oblique to radial sculpture. It appears morphologically very similar to M. gilchristi (G.B. Sowerby III, 1904) (Figures 4G-L), but that species has a completely different West Indian Ocean distribution, ranging from South Africa to Mozambique and northern Madagascar. Despite the observed variability of their shells and the absence of entire specimens of $M$. scabrosum in fresh condition, both species can presently be distinguished through features of the posterior sculptural area. In M. gilchristi, transverse bars of the rib interstices tend to be rather narrow on the disc and become somewhat thinner to even sub-lamellate on the posterior slope, whereas they are slightly thicker throughout in M. scabrosum. In M. gilchristi, additional granules of the interstices are smaller, more delicate and easily broken, with a characteristic, somewhat dorsoventrally compressed and spatula-like shape (Figure 4I). They are usually restricted to the posterior half of the interstices and often more or less expanded into rather thin and rounded flattened processes on the posterior slope (Figure 4K), contrary to M. scabrosum where interstitial granules typically have a roughly conical shape (Figures 4D-E), tend to be stronger, and often extending over most of the width of the interstices. Microcardium scabrosum and M. gilchristi may constitute a pair of sibling species. This could be solved only with additional well preserved Australian material and the possibility of DNA sequencing. Microcardium tenuilamellosum Poutiers, 1981, presently known in the West Pacific from the Philippines, Solomon Islands and Vanuatu, also has a wide posterior sculptural area with an oblique anterior limit. However, it differs markedly from the two preceding species by its dense and lamellate transverse sculpture of rib interstices on the posterior slope, by the absence of proliferation of interstitial tubercles in the posterior area and by the indistinct lunular heart.

\section{ETYMOLOGY}

The species name alludes to the finely and densely spiked aspect of the posterior half of the shell.

\section{Genus Pratulum Iredale, 1924}

Pratulum Iredale, 1924: 182, 207 (as a subgenus of Nemocardium). Type species by original designation: Cardium striatulum thetidis Hedley, 1902; Recent, Australia, New South Wales, off Port Kembla and Cape Three Points.

\section{Pratulum occidentale sp. nov. Poutiers}

Figures 5A-F, 6A-M, 17F

urn:Isid:zoobank.org:act:4787EDE7-34ED-4E1F-AEF1804C630A384E

Nemocardium (Pratulum) thetidis (Hedley, 1902) [pars] — Wilson and Stevenson 1977: 69-71.

\section{MATERIAL EXAMINED}

\section{Holotype}

Australia: Western Australia: Zuytdorp, Off Red Bluff, $24^{\circ} 01.8^{\prime} \mathrm{S}, 113^{\circ} 01.8^{\prime} \mathrm{E}, 100-101 \mathrm{~m}, 08.12 .2005$, Leg. S.M. Slack-Smith \& M.P. Salotti, CSIRO RV 'Southern Surveyor' Cruise SS1005, Nov/Dec 2005, Stn SS1005/133 (WAM S29307, 1 p.v., A.). 


\section{Paratypes}

Australia: Western Australia: North West Shelf, approx. 135 miles N.W. of Roebuck Bay, $17^{\circ} 34^{\prime}$ S, $120^{\circ} 22^{\prime} \mathrm{E}, 188 \mathrm{~m}, 30.11 .1967$, Leg. BMR, MV 'Kos 2', Stn K67-252 (AMS C145.725, 1 s.v., paratype); Ningaloo, Off Point Cloates, $22^{\circ} 50.92^{\prime} \mathrm{S}, 113^{\circ} 30.66^{\prime} \mathrm{E}, 100 \mathrm{~m}$, 09.12.2005, Leg. S.M. Slack-Smith \& M.P. Salotti, CSIRO RV 'Southern Surveyor' Cruise SS1005 Nov/ Dec 2005, Stn SS1005/135 (WAM S29308, 3 p.v., A, paratypes; MNHN-IM-2000-32637, 1 p.v., A, paratype); Zuytdorp, Off Red Bluff, $24.03^{\circ} \mathrm{S}, 113.03^{\circ} \mathrm{E}\left[24^{\circ} 01.8^{\prime} \mathrm{S}\right.$, $\left.113^{\circ} 01.8^{\prime} \mathrm{E}\right], 100-101 \mathrm{~m}, 08.12 .2005$, Leg. S.M. SlackSmith \& M.P. Salotti, CSIRO RV 'Southern Surveyor' Cruise SS1005, Nov/Dec 2005, Stn SS1005/133 (WAM S29446, 3 s.v., paratypes); N.W. of Bluff Point, Geraldton, $27^{\circ} 18^{\prime} \mathrm{S}, 113^{\circ} 16^{\prime} \mathrm{E}, 99 \mathrm{~m}, 09.10 .1963$. Stn CSIRO DM6/204/63 (WAM S15916, 1 s.v., paratype).

\section{Other material}

Australia: Western Australia: Oceanic Shoals, Approx. 170 miles N. of Broome, $15^{\circ} 27^{\prime} \mathrm{S}, 121^{\circ} 31^{\prime} \mathrm{E}$, 210 m, 20.11.1967, Leg. BMR, MV 'Kos 2', Stn K67216 (AMS C145.724, 2 s.v.); N.W. of Cape Leveque, $15^{\circ} 11.1^{\prime} \mathrm{S}, 121^{\circ} 26.9^{\prime} \mathrm{E}$ to $15^{\circ} 12.9^{\prime} \mathrm{S}, 121^{\circ} 25.7^{\prime} \mathrm{E}$, soft bottom, 258-260 m, 17.02.1984, Leg. S. Slack-Smith on FRV 'Soela' Cruise II 1982 (WAM S70659 (ex 25888), 2 s.v.); Approx. 100 miles N.W. of Broome, $16^{\circ} 58^{\prime}$ S, $120^{\circ} 47^{\prime} \mathrm{E}, 194 \mathrm{~m}, 29.11 .1967$, Leg. BMR, MV 'Kos 2', Stn K67-248 (AMS C145.722, 18 s.v.); Rowley Shoals, off Mermaid Reef, $17.4872^{\circ} \mathrm{S}, 120.4606^{\circ} \mathrm{E}$ to $17.4954^{\circ} \mathrm{S}$, $120.4679^{\circ} \mathrm{E}\left[17^{\circ} 29.23^{\prime} \mathrm{S}, 120^{\circ} 27.64^{\prime} \mathrm{E}\right.$ to $17^{\circ} 29.72^{\prime} \mathrm{S}$, $\left.120^{\circ} 28.07 ' \mathrm{E}\right], 184-187 \mathrm{~m}, 20.06 .2007$, Leg. C. Whisson \& O. Gomez, CSIRO RV 'Southern Surveyor' Cruise, Stn SS0507/091 (WAM S34674, 3 s.v.); Rowley Shoals, $17^{\circ} 20^{\prime} \mathrm{S}, 11^{\circ} 10^{\prime} \mathrm{E}, 300 \mathrm{~m}, 20.12 .1969$, Leg. K. Ozawa, Tokyo University of Fisheries Exped. FV 'Umitaka Maru' 1969, Stn UMD/69/21 (WAM S15914, 1 s.v.); Approx. 230 miles W. of Broome, $18^{\circ} 00^{\prime} \mathrm{S}, 118^{\circ} 56^{\prime} \mathrm{E}$, 261 m, 06.11.1967, Leg. BMR, MV 'Espirito Santo', Stn E68-552 (AMS C145.739, 18 s.v.); 130 miles N. of Port Hedland, $18^{\circ} 13^{\prime} \mathrm{S}, 118^{\circ} 37^{\prime} \mathrm{E}, 229 \mathrm{~m}, 07.11 .1968$, Leg. BMR, MV 'Espirito Santo', Stn E68-557 (AMS C145.731, 1 s.v.; AMS C145.732, 8 s.v.); Approx. 230 miles W. Roebuck Bay, $18^{\circ} 30^{\prime} \mathrm{S}, 118^{\circ} 03^{\prime} \mathrm{E}, 238 \mathrm{~m}$, 11.10.1968, Leg. BMR, MV 'Espirito Santo', Stn E68-576 (AMS C145.740, 5 s.v.); North West Shelf, Approx. 135 miles N.W. of Roebuck Bay, $17^{\circ} 34^{\prime} \mathrm{S}$, $120^{\circ} 22^{\prime} \mathrm{E}, 188 \mathrm{~m}, 30.11 .1967$, Leg. BMR, MV 'Kos 2', Stn K67-252 (AMS C145.725, 11 s.v.); 106 nautical miles N. of Port Hedland, $18^{\circ} 30.1^{\prime} \mathrm{S}, 118^{\circ} 36.2^{\prime} \mathrm{E}$ to $18^{\circ} 31.6^{\prime} \mathrm{S}, 118^{\circ} 37^{\prime} \mathrm{E}$, bottom with shells, $136-146 \mathrm{~m}$, 02.04.1982, Leg. J. Marshall on FRV 'Soela' Cruise II 1982 (WAM S70654 (ex 257-88), 13 s.v.); 114 nautical miles N. of Port Hedland, $18^{\circ} 25^{\prime} \mathrm{S}, 118^{\circ} 22^{\prime} \mathrm{E}$, rubble and grey mud, $200 \mathrm{~m}, 02.04 .1982$, Leg. L.M. Marsh on FRV 'Soela' Cruise II 1982 (WAM S70655 (ex 25488), 10 s.v.; WAM S70657 (ex 256-88), 3 s.v. included
2 fragm.); 114 nautical miles N. of Port Hedland, $18^{\circ} 25^{\prime} \mathrm{S}, 118^{\circ} 22^{\prime} \mathrm{E}$, limestone, rubble and grey mud, $201 \mathrm{~m}, 02.04 .1982$, Leg. L.M. Marsh on FRV 'Soela' Cruise II 1982 (WAM S70656 (ex 255-88), 2 s.v.); 90 miles N.W. of Port Hedland, $19^{\circ} 07^{\prime}$ S, $118^{\circ} 15^{\prime}$ E, 88 m, 11.11.1968, Leg. BMR, MV 'Espirito Santo', Stn E68-582 (AMS C145.728, 2 s.v.); 129 nautical miles N.E. of Cape Lambert, $18^{\circ} 38.6^{\prime} \mathrm{S}, 118^{\circ} 07^{\prime} \mathrm{E}$, limestone rubble and dead shells, $150 \mathrm{~m}, 18.08 .1995$, Leg. L.M. Marsh et al., AIMS Survey RV 'Lady Basten' 1995, Stn AIMS/95/LB5B (WAM S15926, 1 s.v.); Approx. 120 miles N. of Port Hedland, $18^{\circ} 42^{\prime} \mathrm{S}, 118^{\circ} 02^{\prime} \mathrm{E}, 161 \mathrm{~m}$, 25.11.1968, Leg. BMR, MV 'Espirito Santo', Stn E68708 (AMS C145.727, 4 s.v.); 100 nautical miles N.W. of Port Hedland, $18^{\circ} 47^{\prime}$ S, $117^{\circ} 58^{\prime} \mathrm{E}, 154 \mathrm{~m}, 28.03 .1982$, Leg. L.M. Marsh, CSIRO FRV 'Soela' Cruise II 1982, Stn SO2/82/10A (WAM S15904, 1 s.v.; WAM S35206, 2 s.v.); 100 nautical miles N.W. of Port Hedland, $18^{\circ} 47^{\prime}$ S, $117^{\circ} 58^{\prime} \mathrm{E}$, grey mud and shell rubble, $154 \mathrm{~m}, 28.03 .1982$, Leg. L.M. Marsh on FRV 'Soela' Cruise II 1982 (WAM S70658 (ex 259-88), 24 s.v.; WAM S70660 (ex 25388), c. 220 s.v., including fragm.); Off Port Hedland, $18^{\circ} 48^{\prime} \mathrm{S}, 117^{\circ} 57^{\prime} \mathrm{E}, 152 \mathrm{~m}, 11.1968$, Leg. BMR, MV 'Espirito Santo', Stn E68-580 (AMS C145.737, 1 s.v.; AMS C145.738, 2 s.v.); 109 nautical miles N.W. of Port Hedland, $18^{\circ} 56^{\prime} \mathrm{S}, 117^{\circ} 21^{\prime} \mathrm{E}, 201-202 \mathrm{~m}, 14.04 .1982$, Leg. L.M. Marsh, CSIRO FRV 'Soela' Cruise II 1982, Stn SO2/82/48 (WAM S57141, 1 s.v.; WAM S57160, 1 s.v.); Approx. 130 miles N.W. of Port Hedland, $19^{\circ} 08^{\prime} \mathrm{S}, 117^{\circ} 12^{\prime} \mathrm{E}, 155 \mathrm{~m}, 20.10 .1968$, Leg. BMR, MV 'Espirito Santo', Stn E68-613 (AMS C145.733, 1 s.v.); Approx. 240 miles N.W. of Port Hedland, $19^{\circ} 12^{\prime} \mathrm{S}, 115^{\circ} 57^{\prime} \mathrm{E}, 274 \mathrm{~m}, 24.11 .1968$, Leg. BMR, MV 'Espirito Santo', Stn E68-638 (AMS C145.730, 1 s.v.); Approx. 190 miles N.W. of Port Hedland, $19^{\circ} 24^{\prime} \mathrm{S}, 115^{\circ} 52^{\prime} \mathrm{E}, 238 \mathrm{~m}, 27.11 .1968$, Leg. BMR, MV 'Espirito Santo', Stn E68-654 (AMS C145.734, 14 s.v.); Approx. 190 miles N.W. of Port Hedland, $19^{\circ} 25^{\prime} \mathrm{S}, 115^{\circ} 51^{\prime} \mathrm{E}, 256 \mathrm{~m}, 24.11 .1968$, Leg. BMR, MV 'Espirito Santo', Stn E68-646 (AMS C145.735, 5 s.v.); Approx. 190 miles N.W. of Port Hedland, $19^{\circ} 32^{\prime} \mathrm{S}, 115^{\circ} 49^{\prime} \mathrm{E}, 183 \mathrm{~m}, 27.11 .1968$, Leg. BMR, MV 'Espirito Santo', Stn E68-653 (AMS C145.736, 6 s.v.); Approx. 200 miles N.W. of Port Hedland, 19² $29^{\prime}$ S, $115^{\circ} 38^{\prime} \mathrm{E}, 320 \mathrm{~m}, 28.11 .1968$, Leg. BMR, MV 'Espirito Santo', Stn E68-660 (AMS C145.729, 3 s.v.); Pilbara Offshore, Off Onslow, 20 $0^{\circ} 12^{\prime} 14.76 " \mathrm{~S}, 115^{\circ} 8^{\prime} 20.75^{\prime \prime} \mathrm{E}$ to $20^{\circ} 12^{\prime} 8.28^{\prime \prime} \mathrm{S}, 115^{\circ} 8^{\prime} 15.71 " \mathrm{E}, 100 \mathrm{~m}, 11.06 .2007$, Leg. C. Whisson \& O. Gomez, CSIRO RV 'Southern Surveyor' Cruise, Stn SS0507/018 (WAM S32785, 1 p.v., A); Off Barrow Island, $20.9847^{\circ} \mathrm{S}, 114.9070^{\circ} \mathrm{E}$ [20 $\left.59.08^{\prime} \mathrm{S}, 114^{\circ} 54.42^{\prime} \mathrm{E}\right], 100-101 \mathrm{~m}, 13.12 .2005$, Leg. S.M. Slack-Smith \& M.P. Salotti, CSIRO RV 'Southern Surveyor' Cruise SS1005 Nov/Dec 2005, Stn SS1005/135 (WAM S29311, 1 s.v.); Off Barrow Island, $20^{\circ} 58^{\prime} 51.6^{\prime \prime S}, 114^{\circ} 43^{\prime} 24.96 " \mathrm{E}, 205-210 \mathrm{~m}$, 09.06.2007, Leg. C. Whisson \& O. Gomez, CSIRO 
RV 'Southern Surveyor' Cruise, Stn SS0507/006 (WAM S32880, 2 s.v.); Ningaloo, Off North West Cape, on N.W. Shelf slope, $21^{\circ} 32.083^{\prime} \mathrm{S}, 11^{\circ} 07.53^{\prime} \mathrm{E}$, 190 m, 25.03.2002, Leg. J. Fromont, L.M. Marsh \& P. Alderslade, AIMS North West Cape Survey II 2002, Stn 15 (WAM S15921, 4 s.v.); W. of North West Cape, $21^{\circ} 50^{\prime} \mathrm{S}, 113^{\circ} 46^{\prime} \mathrm{E}, 137 \mathrm{~m}, 06.10 .1963$, CSIRO HMAS 'Diamantina' Cruise II 1963, Stn DM6/173/63 (WAM S70649 (ex 199-67), 13 s.v.); Off Ningaloo (South), $22.0795^{\circ} \mathrm{S}, 113.7960^{\circ} \mathrm{E}$ to $22.0873^{\circ} \mathrm{S}, 113.7940^{\circ} \mathrm{E}$ [22 ${ }^{\circ} 04.77^{\prime} \mathrm{S}, 113^{\circ} 47.76^{\prime} \mathrm{E}$ to $\left.22^{\circ} 05.24^{\prime} \mathrm{S}, 113^{\circ} 47.67^{\prime} \mathrm{E}\right]$, 201-206 m, 10.12.2005, Leg. S.M. Slack-Smith, \& M.P. Salotti, CSIRO RV 'Southern Surveyor' Cruise SS1005 Nov/Dec 2005, Stn SS1005/146 (WAM S29447, 3 s.v.); Off Point Cloates, $22.8487^{\circ} \mathrm{S}, 113.5110^{\circ} \mathrm{E}\left[22^{\circ} 50.92^{\prime} \mathrm{S}\right.$, $\left.113^{\circ} 30.66^{\prime} \mathrm{E}\right], 100 \mathrm{~m}, 09.12 .2005$, Leg. S.M. SlackSmith \& M.P. Salotti, CSIRO RV 'Southern Surveyor' Cruise SS1005 Nov/Dec 2005, Stn SS1005/135 (WAM S29308, 5 p.v., A); SW of Point Cloates, $23^{\circ} 25^{\prime} \mathrm{S}$, $113^{\circ} 14^{\prime} \mathrm{E}$, sand \& shells, $186.5 \mathrm{~m}, 07.10 .1963$, CSIRO HMAS 'Diamantina' Cruise II 1963, Stn DM6/185/63 (WAM S70650 (ex 205-67), 5 s.v.); S.W. of Point Cloates, $23^{\circ} 25^{\prime} \mathrm{S}, 113^{\circ} 14^{\prime} \mathrm{E}, 20 \mathrm{~m}, 07.10 .1963$, CSIRO HMAS 'Diamantina' Cruise II 1963, Stn DM6/63/185 (WAM S78332, 1 s.v.); Zuytdorp, Off Red Bluff, $24.03^{\circ} \mathrm{S}, 113.03^{\circ} \mathrm{E}\left[24^{\circ} 01.8^{\prime} \mathrm{S}, 113^{\circ} 01.8^{\prime} \mathrm{E}\right], 100-101$ m, 08.12.2005, Leg. S.M. Slack-Smith \& M.P. Salotti, CSIRO RV 'Southern Surveyor' Cruise SS1005, Nov/ Dec 2005, Stn SS1005/133 (WAM S29307, 41 s.v., 1 p.v., A; WAM S29445, 1 s.v.; WAM S29446, 39 s.v.); Off Red Bluff, $24.0437^{\circ} \mathrm{S}, 113.0270^{\circ} \mathrm{E}\left[24^{\circ} 02.62^{\prime} \mathrm{S}\right.$, $\left.113^{\circ} 01.62^{\prime} \mathrm{E}\right], 100 \mathrm{~m}, 08.12 .2005$, Leg. S.M. SlackSmith \& M.P. Salotti, CSIRO RV 'Southern Surveyor' Cruise SS1005 Nov/Dec 2005, Stn SS1005/126 (WAM S29442, 5 s.v.); N.W. of Carnarvon, 2431'S, $112^{\circ} 41^{\prime} \mathrm{E}$, sand \& shells, $111.5 \mathrm{~m}$, CSIRO HMAS 'Diamantina' Cruise II 1963, Stn DM6/194/63, 08.10.1963 (WAM S70651 (ex 206-67), 3 s.v.); Off Carnarvon, $24.6194^{\circ} \mathrm{S}, 112.6660^{\circ} \mathrm{E}\left[24^{\circ} 37.16^{\prime} \mathrm{S}\right.$, $\left.112^{\circ} 39.98^{\prime} \mathrm{E}\right], 100 \mathrm{~m}, 07.12 .2005$, Leg. S.M. Slack-Smith \& M.P. Salotti, CSIRO RV 'Southern Surveyor' Cruise SS1005 Nov/Dec 2005, Stn SS1005/120 (WAM S29440, 1 s.v.); W. of Dirk Hartog Island, $25^{\circ} 30^{\prime} \mathrm{S}, 112^{\circ} 22^{\prime} \mathrm{E}$, mud, clay \& shells, $142.5 \mathrm{~m}, 08.10 .1963$, CSIRO HMAS 'Diamantina' Cruise II 1963, Stn 198 (WAM S70652 (ex 207-67), 3 s.v.); W. of Dirk Hartog Island, $25.9076^{\circ} \mathrm{S}, 112.8230^{\circ} \mathrm{E}\left[25^{\circ} 54.46\right.$ 'S, $\left.112^{\circ} 49.38^{\prime} \mathrm{E}\right], 100$ m, 06.12.2005, Leg. S.M. Slack-Smith \& M.P. Salotti, CSIRO RV 'Southern Surveyor' Cruise SS1005 Nov/ Dec 2005, Stn SS1005/112 (WAM S25819, 5 s.v.; WAM S29389, 1 s.v.); N.W. of Bluff Point, Geraldton, $27^{\circ} 18^{\prime}$ S, $113^{\circ} 16^{\prime} \mathrm{E}, 99 \mathrm{~m}, 09.10 .1963$. Stn CSIRO DM6/204/63 (WAM S15916, 1 s.v.); N.W. of Bluff Point, $27^{\circ} 18^{\prime}$ S, $113^{\circ} 16^{\prime} \mathrm{E}$, bottom with sponge, seastar \& oxystomata, 99 m, 09.10.1963, CSIRO Stn DM6/204/63 (WAM S70653 (ex 1043-66), 44 s.v.).

\section{DESCRIPTION}

Shell equivalve, inflated and subequilateral, about as high as long, subquadrate ovate in outline and rather small for the genus (up to $12.1 \mathrm{~mm}$ long). Umbones prosogyrate, usually positioned just anterior to the midlength of the shell. The dorsal margin is slightly more oblique anteriorly than posteriorly. Posterior margin nearly straight, forming a rounded angle with the ventral margin, becoming dorsally more convex and oblique to the posterior dorsal margin.

Outer sculpture rather coarse and heterogeneous, changing abruptly on the posterior area of the valves. Radial ribs small and numerous (from 64 to 90, mean 77), well developed over most of the outer surface. Limit between the two zones of sculpture not cutting obliquely, radial ribbing on major part of shell height, and then relative width of both types of sculpture remaining constant during ontogeny.

Anterior and median sculptural zones with many radial ribs (from 39 to 55, mean 49) and slightly wider and low interstices. Ribs well-marked and rounded but relatively low and crossed by numerous, branched or interrupted, approximately commarginal and anastomosing undulating ridges. These tend to form a slightly nodulous reticulate pattern with small tubercles towards the anterior side of the valves. Antero-dorsal margin of the valves raised and somewhat thickened anterior to the umbones, forming a slightly inequivalve, narrow lanceolate process. Lunular sector poorly defined and nearly smooth.

Posterior sculptural area extending over a quarter of the valve surface, with about 28 radial ribs (from 26 to 31) and numerous, often well developed spines. Ribs thinner than in median area, with steeper sides and deeper, larger interstices, progressively weakening toward the Postero-dorsal margin, each bearing on top a row of rather strong and protruding tubercles or spines. Spine insertion on ribs more or less anterior, often markedly encroaching on the anterior side of the rib and inside the interstice, forming somewhat oblique transverse bulgings superficially looking like low 'cross bars' when spines are completely worn off. Rows of spines often alternately larger and smaller on the posterior area; spine shape variable, somewhat laterally compressed or rounder, often more or less concave dorsally. Postero-dorsal margin somewhat depressed in the left valve, more convex in the right valve, forming a tooth-like thickening that overhangs the margin of the left valve.

Periostracum thin and translucent, fibrous toward the periphery of the valves and on the posterior zone where it tends to form irregular threads and simulates a thin commarginal sculpture.

Hinge of each valve with two unequal cardinal teeth, the more ventral cardinal much larger, prominent and curved, the more dorsal forming a small tubercle; 

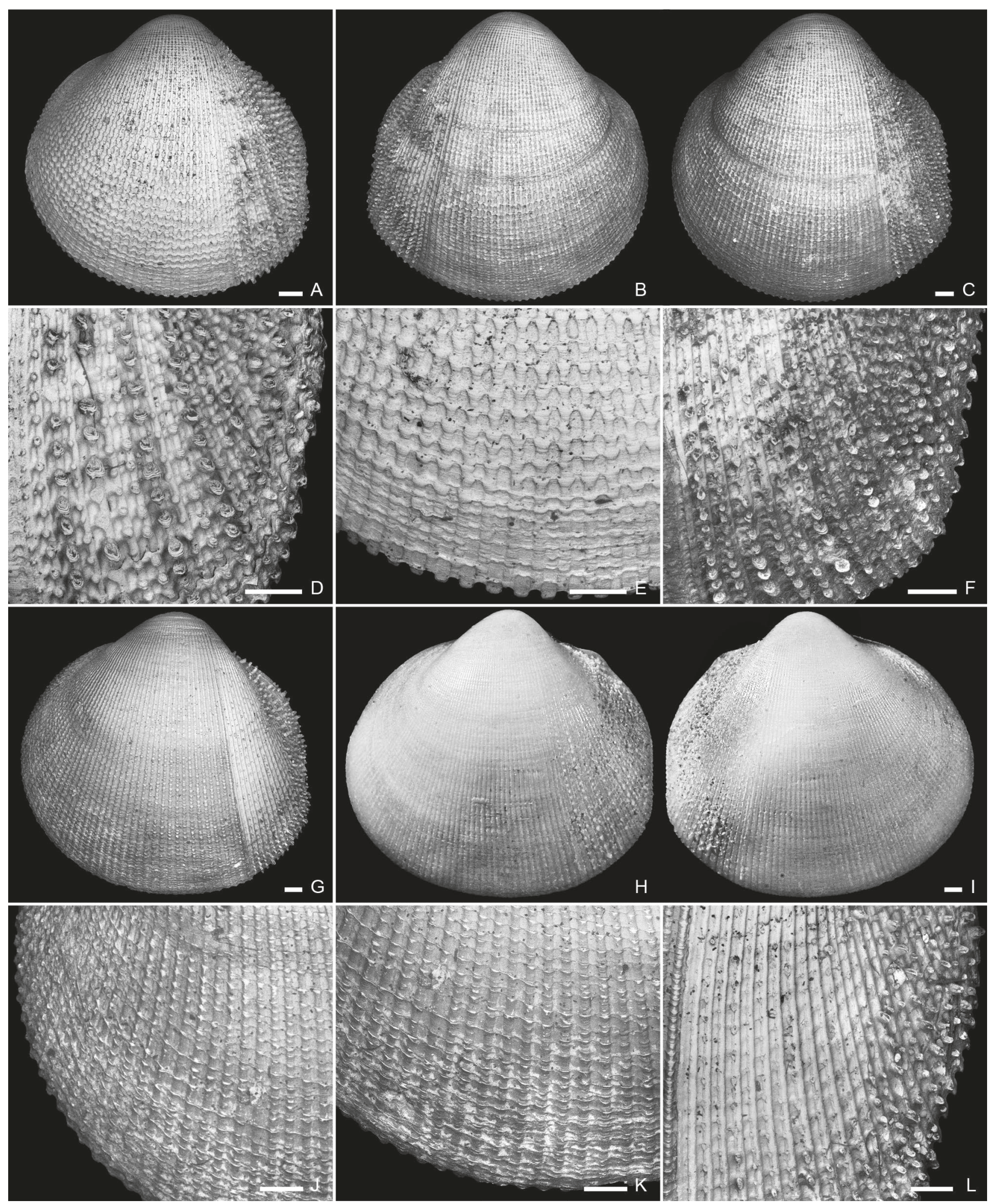

FIGURE 5 A, B, C, D, E, F, Pratulum occidentale sp. nov. A, D-E, N.W. of Port Hedland, WA: AMS C145.728, L 7.4 mm; A exterior of I.V., D posterior sculpture, E anterior sculpture; B-C,F, Off Point Cloates, WA: WAM S29308, paratype, L $9.9 \mathrm{~mm}$; B exterior of r.V., C exterior of I.V., F posterior sculpture.

G, H, I, J, K, L, Pratulum thetidis (Hedley, 1902). G, J-L, Western Port Bay, Victoria: MNHN-IM-2014-6070, $L 11.0 \mathrm{~mm}$; G exterior of r.V., J anterior slope, $\mathrm{K}$ median part of anterior sculpture, $L$ posterior sculpture; H-I, Off Perth, WA: WAM S29300, L 8.5 mm; H exterior of r.v., I exterior of I.v. Scale bars: 0.5 mm. 
cardinal teeth joined by a thin saddle in the right valve, separated by a deep socket in the left valve. Posterior lateral teeth farther to cardinals than anterior laterals; left valve with single posterior lateral and single anterior submarginal lateral; right valve with single submarginal posterior lateral and paired anterior laterals separated by a deep socket, with most dorsal anterior lateral much reduced.

Internal margins with fine and regular crenulations in accordance with the outer radial sculpture, disappearing toward the dorsal ends of the anterior and posterior margins. Protruding elements of crenulations corresponding respectively with radial ribs in the posterior sculptural area, and with rib interstices in the anterior area.

Shell white, often light pinkish orange on posterior zone, umbonal area and antero-dorsal margin, sometimes with two short rays of orange on umbo and pale pinkish banding.

\section{DISTRIBUTION AND ECOLOGY}

An endemic tropical WA species (Figure 17F) found from 20-320 metres deep, living in 100-101 metres depth.

\section{REMARKS}

Pratulum thetidis (Figures 3N-P, 5G-L), an endemic South and East Australian species mainly confined to temperate waters, differs from $P$. occidentale sp. nov. by its relatively larger size (largest specimen measured $18.0 \mathrm{~mm}$ long), by being relatively less high and less inflated, by the finer nature of the sculpturing with much finer anastomosed commarginal threads of anterior and median areas, and rather small spines of posterior area, making the sculptural heterogeneity usually rather discreet to the naked eye. The coarser sculpture and strong heterogeneity between the two sculptural zones of the new species bear a superficial resemblance to the sculpture of Microcardium. However, diagnostic sculptural patterns of rib interstices in Microcardium (with rows of spines alternating with rows of cross-bars or transverse lamellae, as high as or higher than ribs) never occur in $P$. occidentale sp. nov. All spines are distinctly related to radial ribs, and the low 'transverse' sculpture of interstices merely correspond to basal bulging of the spines arising along the anterior side of the ribs. Pratulum occidentale and $P$. thetidis seem to be strictly allopatric in WA (Figure 17F), with the area between Shark Bay and the Houtman Abrolhos Islands as a mutual border (S. end of range and $\mathrm{N}$. end of range, respectively).

\section{ETYMOLOGY}

Compared to the two other Pratulum species from temperate environments ( $P$. pulchellum (Gray in Dieffenbach, 1843) in New Zealand, and the nearby P. thetidis (Hedley, 1902) in Southern Australia),
P. occidentale has a more westerly distribution in subtropical waters of WA, as suggested by its species name.

\section{Genus Trifaricardium Kuroda \& Habe, 1951}

Trifaricardium Kuroda \& Habe in Kuroda, 1951: 86 (nomen nudum).

Trifaricardium Kuroda \& Habe in Habe, 1951: 152-153, fig. 328. Type species by monotypy: Trifaricardium nomurai Kuroda \& Habe in Kuroda, 1951; Recent, Japan.

\section{Trifaricardium morrisoni ter Poorten \& Huber, 2007}

Figures 6N-R, 17G

Trifaricardium morrisoni ter Poorten \& Huber, 2007: 71-74, figs 5-9.

\section{MATERIAL EXAMINED}

Australia: Western Australia: Oceanic Shoals, N.W. of Cape Leveque, $14^{\circ} 52.2^{\prime} \mathrm{S}, 121^{\circ} 41.7^{\prime} \mathrm{E}$ to $14^{\circ} 53.7^{\prime} \mathrm{S}, 121^{\circ} 39.9^{\prime} \mathrm{E}, 220-224 \mathrm{~m}$, Engel trawl on soft bottom, 16.02.1984. Leg. S.M. Slack-Smith, Stn SO1/84/085 (paratype, WAM S15911, 1 s.v.); W.N.W. of Lacepede Archipelago, $15^{\circ} 57.2^{\prime} \mathrm{S}, 120^{\circ} 46.2^{\prime} \mathrm{E}$ to $15^{\circ} 59.05^{\prime} \mathrm{S}, 120^{\circ} 44.6^{\prime} \mathrm{E}, 296-298 \mathrm{~m}$, Engel trawl on soft bottom, 10.02.1984. Leg. S.M. Slack-Smith, Stn SO1/84/055 (paratype, WAM S15908, 1 s.v.); Rowley Shoals, $17^{\circ} 20^{\prime} \mathrm{S}, 119^{\circ} 10^{\prime} \mathrm{E}, 300 \mathrm{~m}, 20.12 .1969$. Leg. K. Ozawa, Tokyo Univeristy of Fisheries Exped. FV 'Umitaka Maru', Stn UMD/69/21 (holotype, WAM S29458, 1 s.v.; paratypes WAM S15912, 13 s.v.; paratypes ZMA.MOLL.139454, 4 s.v.); North West Shelf, 100 nautical miles N.W. of Port Hedland, $18^{\circ} 47^{\prime} \mathrm{S}, 117^{\circ} 58^{\prime} \mathrm{E}, 154 \mathrm{~m}$, triangular dredge, grey mud and shell rubble, 28.03.1982. Leg. L.M. Marsh, Stn SO2/82/10A (paratype, WAM S15903, 1 s.v.).

\section{DESCRIPTION}

Shell relatively small (L 10-12 mm), thin, rounded, length slightly exceeding height. Nearly equilateral with postero-dorsal margin slightly truncated. Outer surface with heterogeneous rib structure, divided into two very differently sculptured and unequally sized zones. Posterior zone very large, comprising approximately 95 fine thread-like radial ribs. Interstices punctuated; every second, third or fourth carrying small but erect, blunt spinelets, hollowed dorsally. Occasionally, a secondary row of spinelets can be present. Towards the posterior slope, punctuations in the interstices becoming progressively of a more laminate nature and consisting of densely placed laminae. Ornamentation abruptly 
changing into a strongly different morphology towards the anterior slope, with numerous very fine, slightly undulating commarginal threads, crossed by highly weakened, unsculptured radial riblets. Lunule smooth, not well delimited; lunular heart poorly defined, margins raised and thickened on both valves. External and internal colour uniformly white.

\section{DISTRIBUTION AND ECOLOGY}

This species is so far only known from the type material and confined to the outer edge of the continental shelf of northern WA (Figure 17G), found in deep water from 154-300 metres (based on single valves). Given these oceanic tropical records, an endemic WA occurrence does not seem likely, and it may be predicted that the true distribution range will cover parts of the Central IWP as well.

\section{REMARKS}

Poutiers (1992: 142, fig. 2M) mentions an as yet undescribed but closely related Trifaricardium species from QLD, represented in the WAM collections by three valves (WAM S78148), originating from East of Caloundra Island, taken at a depth of 65-75 fms (119-137 metres). It differs from $T$. morrisoni by its greater number of sculptured radial rows, which are also coarser.

\section{Trifaricardium nomurai Kuroda \& Habe, 1951}

Figures 6S-U

Cardium (Acanthocardia) cancellatum Nomura, 1933: 81-82, pl. 3 figs 9a-b (non Gmelin, 1791).

Trifaricardium nomurai Kuroda \& Habe in Kuroda, 1951: 86.

Trifaricardium nomurai Kuroda \& Habe in Kuroda, 1951 — ter Poorten 2009: pl. 20 fig. 12, pl. 22 figs 6-9; Huber 2010: 307, fig., ter Poorten 2011: pl. 1111 figs 5-6.

\section{MATERIAL EXAMINED}

Australia: Western Australia: Oceanic Shoals, Rowley Shoals, $17^{\circ} 20^{\prime}$ S, $119^{\circ} 10^{\prime} \mathrm{E}, 300 \mathrm{~m}, 20.12 .1969$. Leg. K. Ozawa, Tokyo University of Fisheries Exped. FV 'Umitaka Maru', Stn UMD/69/21 (WAM S29459, 1 s.v.); Rowley Shoals, $17^{\circ} 20^{\prime} \mathrm{S}, 119^{\circ} 10^{\prime} \mathrm{E}, 260 \mathrm{~m}$, 20.12.1969. Leg. K. Ozawa, Tokyo Univerisity of Fisheries Exped. FV 'Umitaka Maru', Stn UMD/69/20 (WAM S39961, 1 s.v.).

\section{DESCRIPTION}

Shell medium sized (H 20-23 mm), rather solid, inflated, roughly quadrangular with rounded anterior and ventral margins and slightly truncated posterior margin. Heterogeneous rib structure, surface divided into two very differently sculptured and unequally sized zones, in total between 110-120 minute radial ribs. Anterior zone covering less than a quarter of the shell, having low and unsculptured rounded radial ribs, crossed by coarse, strongly undulating, anastomose commarginal threads. Posterior zone covering more than three-quarters of the shell; interstices of this zone with transverse bars, every second to fourth bearing small, blunt spinelets. Lunular area vaguely bordered, generally smooth; lunular heart a simple ovate and rounded bulge of the dorsal margin, slightly larger on right valve. Shell exterior and interior entirely white, sometimes with a slight hue of lemon-yellow on the posterior slope.

\section{DISTRIBUTION AND ECOLOGY}

In WA only known from two worn samples, found in deep water off Rowley Shoals (single valves, depth range 260-300 metres). Until recently this species was only known from Japan and the South China Sea. Ter Poorten and Huber (2007) have shown that it has a much larger distribution than currently known, encompassing the Philippines to offshore in northern WA. Additionally, material from Papua New Guinea has become known (New Ireland, MNHN, det. TP).

\section{REMARKS}

The very limited material available suggests a comparable WA geographic and bathymetrical distribution to that of Trifaricardium morrisoni. Recent phylogenetic work places $T$. nomurai in a clade with seven Microcardium species (Herrera et al. 2015). This casts doubt on the generic status of Trifaricardium. Additional DNA analyses based on more material, including Microcardium peramabile (Dall, 1881), the type species of Microcardium, will be needed to clarify this finding.

\section{Subfamily 'Orthocardiinae' Schneider, 2002}

\section{REMARKS}

The genera Lyrocardium and Afrocardium reported herein have previously been assigned to Laevicardiinae (Schneider 1995) and Orthocardiinae (Schneider 2002) respectively. Cardium victor Angas, 1872 (Table 1) has been transferred to Freneixicardia by ter Poorten (2009), a genus that was also assigned to Orthocardiinae (Schneider 2002). All three genera are grouped in clade B-1 of Herrera et al. (2015) with Lyrocardium not closely related to any other genus belonging to Laevicardiinae. Although, awaiting additional combined molecular and morphological research, Orthocardiinae is tentatively applied for the genera in this clade. 


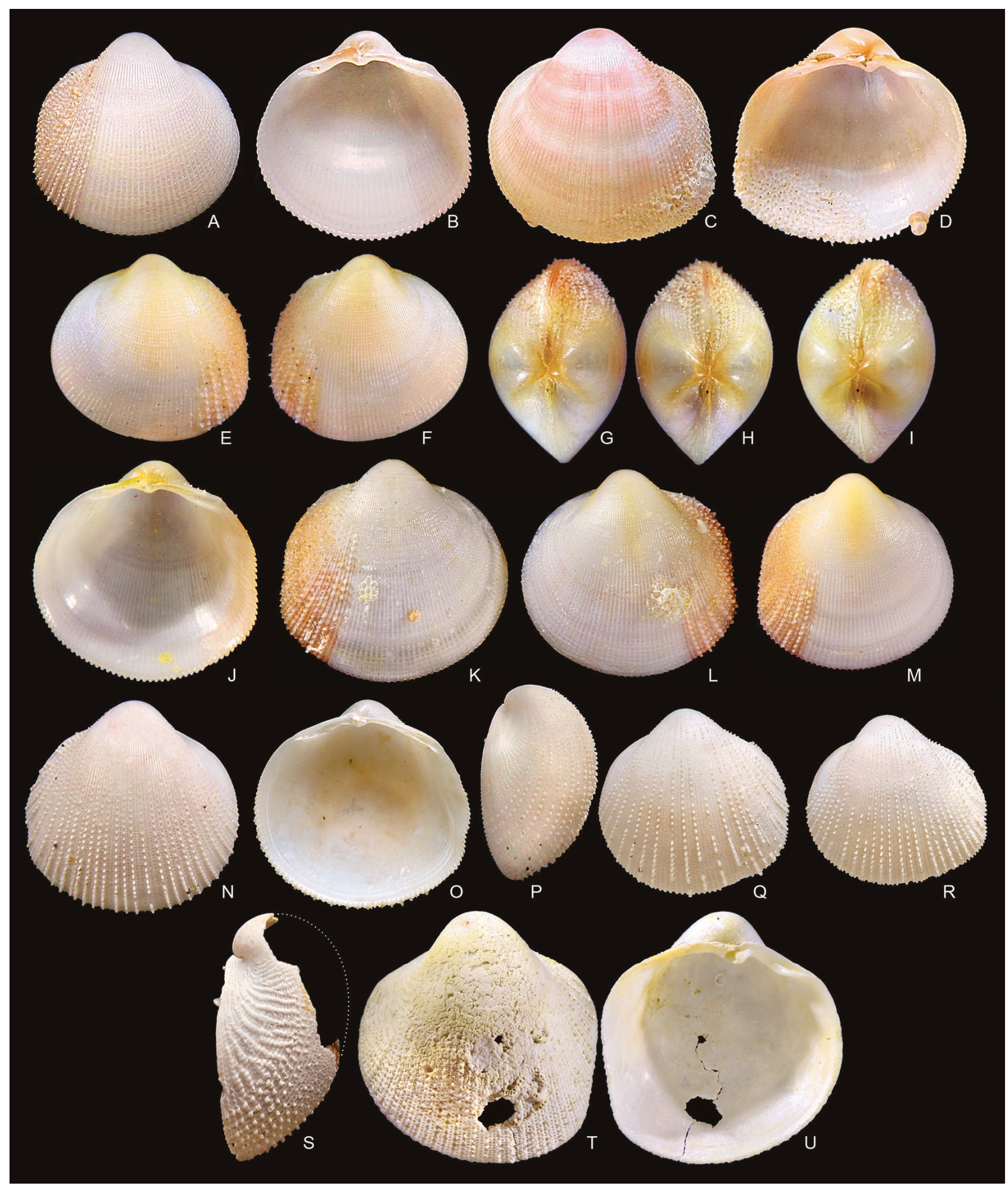

FIGURE 6 A, B, C, D, E, F, G, H, I, J, K, L, M, Pratulum occidentale sp. nov. A-B, N. of Bluff Point, WA: WAM S15916, paratype, length $9.0 \mathrm{~mm}$. A, exterior of r.v., B, interior of r.v.; C-D, off Red Bluff, WA: WAM S29445, length $10.0 \mathrm{~mm}$. C, exterior of I.v., D, interior of I.v.; E-I, off Red Bluff, WA: WAM S29307, holotype, length $5.6 \mathrm{~mm}$. E, exterior of I.v., F, exterior of r.V., G-I, dorsal under slightly different light conditions and angles; J-M, off Red Bluff, WA: WAM S29446, paratypes, J-K, length 7.7 mm, J, interior of r.V., K, exterior of r.v., L, length $7.3 \mathrm{~mm}$, exterior of I.v., M, length $6.6 \mathrm{~mm}$, exterior of r.v.

N, O, P, Q, R, Trifaricardium morrisoni ter Poorten \& Huber, 2007. S. of Rowley Shoals, WA. N-O, WAM S29458, holotype, length $11.9 \mathrm{~mm}$. N, exterior of r.V., O, interior of r.V., P-Q, ZMA.MOLL.139454, paratypes. P-Q, length $11.1 \mathrm{~mm}, \mathrm{P}$, anterior of I.V., Q, exterior of I.V., R, length $10.5 \mathrm{~mm}$, exterior of I.v.

S, T, U, Trifaricardium nomurai Kuroda \& Habe, 1951. S. of Rowley Shoals, WA. S, WAM S29459, height $16.0 \mathrm{~mm}$ (fragm.), anterior of I.v.; T-U, WAM S39961, height $17.2 \mathrm{~mm}$ (defect), T, exterior of I.v., U, interior of I.v. 


\section{Genus Afrocardium Tomlin, 1931}

Afrocardium Tomlin, 1931: 449-450 (as a subgenus of Fragum). Type species by original designation: Fragum (Afrocardium) shepstonense Tomlin, 1931; Recent, Port Shepstone, Kwazulu Natal, South Africa.

\section{Afrocardium richardi (Audouin, 1826)}

Figures 7A-I, 19A

Cardium richardi Audouin, 1826: 51.

Cardium carditaeforme Reeve, 1845: sp. 127, pl. 22 fig. 127.

Cardium arabicus Issel, 1869: 77.

Cardium skeeti Hedley, 1906: 476, pl. 38 fig. 25.

Cardium (Fragum) crenelloides Melvill, 1909: 75, 134, pl. 5 fig. 13 .

Cardium (Fragum) roseolum Melvill, 1909: 134, pl. 5 fig. 14.

Cardium (Fragum) rubescens E.A. Smith, 1911: 317-318, fig.

Cardium euglyptum G.B. Sowerby III, 1914: 480, pl. 19 fig. 14.

Cardium ebaranum Yokoyama, 1927: 430-431, pl. 48 fig. 15 .

Afrocardium skeeti (Hedley, 1906) - Lamprell and Whitehead 1992: pl. 32 fig. 215.

Afrocardium richardi (Audouin, 1826) - ter Poorten 2009: pl. 5 fig. 6, pl. 6 figs 6-10; Huber 2010: 291, fig., ter Poorten 2011: pl. 1091 figs 2-6.

\section{MATERIAL EXAMINED}

Australia: Northern Territory: Arnhem Wessel, central Arnhem Land, 17 nautical miles NNW. f Cape Stewart, wreck of M.V. "SANYO MARU", $11^{\circ} 41.48^{\prime}$ S, 134³6.71'E, 23 m, 20.04.2002. Leg. R.C. Willan (NTM P.19940, 1 p.v., A); Timor Sea, rocky shoal $30 \mathrm{~km}$ due

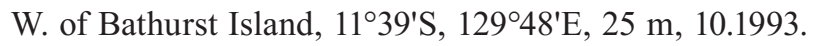
Leg. I.A. Knuckey (NTM P.8217, 7 p.v., A); 90 nautical miles west of Darwin, western end of Flat Top Bank, $12^{\circ} 16.8^{\prime} \mathrm{S}, 129^{\circ} 14^{\prime} \mathrm{E}, 31 \mathrm{~m}, 17.05 .1992$. Leg. R.C. Willan (NTM P.37662, 5 s.v.).

Australia: Western Australia: North West Shelf, W. of Broome, $17^{\circ} 58^{\prime} \mathrm{S}, 122^{\circ} 14^{\prime} \mathrm{E}$ (Egaz), $90 \mathrm{~m}, 21.12 .1969$. Leg. K. Ozawa, Tokyo Uni of Fisheries Exped. FV 'Umataka Maru' 1969, Stn UMD6927 (WAM S57165, 1 s.v.); Ningaloo, W. of North West Cape, $21^{\circ} 50^{\prime} \mathrm{S}, 113^{\circ} 46^{\prime} \mathrm{E}$, 75 fms (137 m), 06.10.1963. CSIRO HMAS 'Diamantina' Cruise II 1963, Stn DM6/173/63 (WAM S15920, 1 s.v.).

\section{Literature records}

ALA / OZCAM: Circa 140 miles N. of Cape Leveque, 12.11.1967 (AMS C.451405, det. J. Schneider).

\section{DESCRIPTION}

Shell small to medium (L 10-20 mm), thin shelled, outline highly variable, from submodioliform to oblique quadrangular, strongly inequilateral with beaks towards the anterior and occasionally a slight concave ventral margin. Posterior margin markedly digitate. Between 36-43 low radial ribs, slightly concave with a central groove; in early juveniles of alternating width. Ribs heavily ornamented with often irregular, close-set squamose scales, posteriorly short spinose. Interstices with commarginal striae. Hinge line long and bent with posterior laterals far from cardinal teeth. Exterior colours extremely variable: often various shades of red-brown, orange, pink, lemon, purple, in the majority with darker streaks posteriorly. Interior colours similarly variable.

\section{DISTRIBUTION AND ECOLOGY}

Both WA records of this species come from deeper water (90-137 meters depth) and originate from the northern part of the state (Figure 19A), in agreement with the wide tropical Indo-West Pacific distribution of the species. Afrocardium richardi has been found alive nestling in a crevice within a block of living coral on a rocky reef (QLD, NTM P.40393) and attached to a nylon monofilament net inside pearl oyster spatcollecting bags, suspended 5 metres above clean sand substrate with sparse encrusting fauna (NT, NTM P.8217). Both records add further evidence to its expected epifaunal nestling habit, very much like that of the shallow water photosymbiotic fragine, Fragum mundum.

\section{REMARKS}

Cardium skeeti Hedley, 1906, described from QLD (Masthead Island), is considered a junior synonym of A. richardi. It was reported 'an abundant species in 17-20 fathoms' (Hedley 1906: 476). Hedley's syntypes, present in AMS C18858 (Hylleberg 2004: 918, fig.), NMW 1955.158.1237 (Meechan 1987) MNHN IM2014-5514 (10 valves, examined by the first author, Figures 7G-I), NHMUK 1908.7.7.107-110 (four valves, examined by the authors, Figures 7E-F), USNM 201420 (five valves, examined by the first author) and ANSP 94824 (four valves, examined by the first author), show a large intraspecific variability, mainly affecting shell shape and colouration but not rib number and sculpture, due to the cryptic epifaunal life habit often referred to as nestling (and utilizing byssal attachment) (ter Poorten 


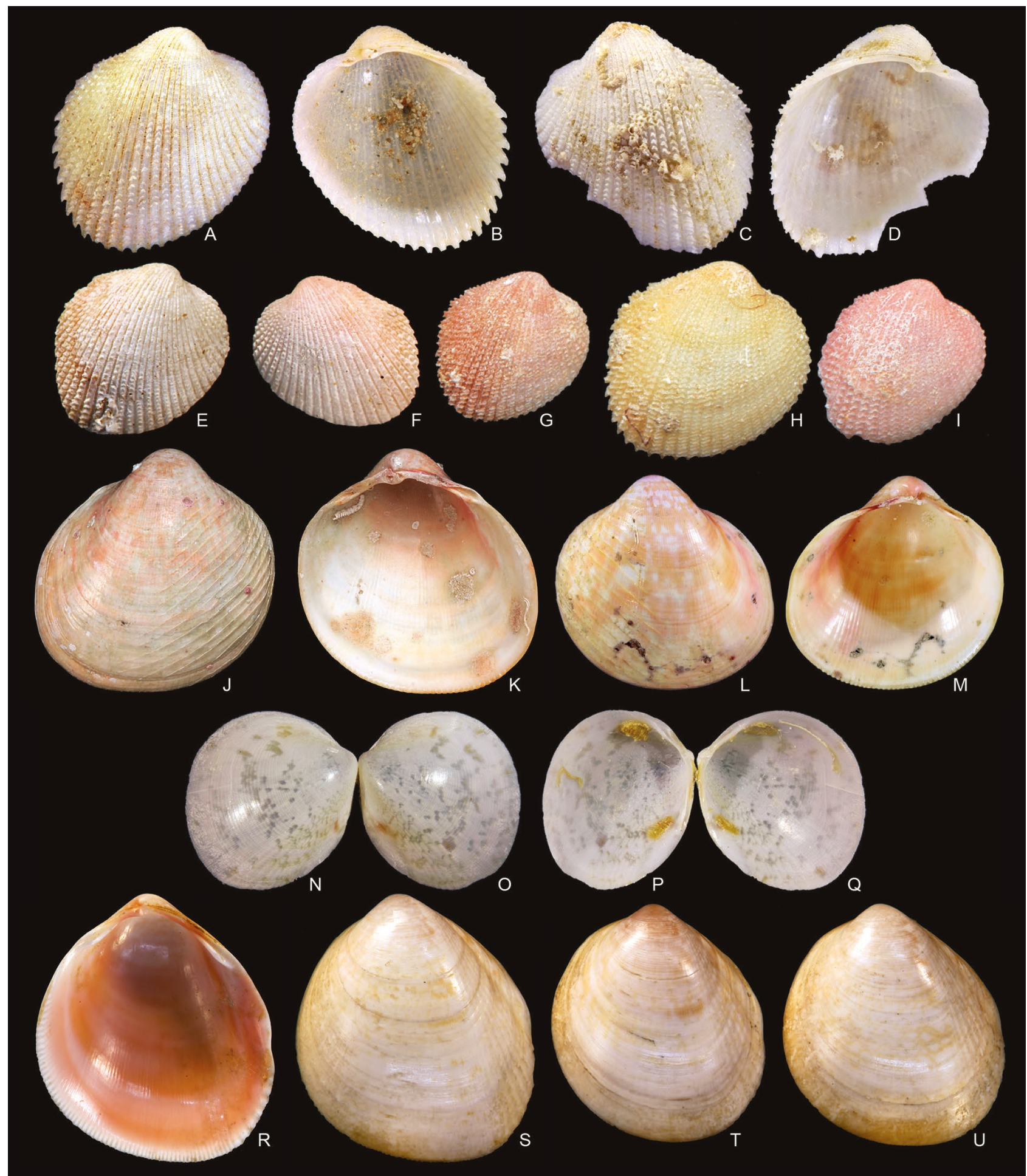

FIGURE 7 A, B, C, D, E, F, G, H, I, Afrocardium richardi (Audouin, 1826). A-B, W off North West Cape, WA: WAM S15920, length $7.2 \mathrm{~mm}$. A, exterior of r.v., B, interior of r.v.; C-D, W of Broome, WA: S57165, length $8.6 \mathrm{~mm}$ (defect). C, exterior of I.V., D, interior of I.v.; E-I, Syntypes of Cardium skeeti Hedley, 1906, Masthead Island, QLD. E-F, NHMUK 1908.7.7.107-110, E, length $4.7 \mathrm{~mm}$, exterior of r.v., F, length 4.5 mm, exterior of I.v., G-I, MNHN IM-2014-5524, exterior of r.v., G, length $4.1 \mathrm{~mm}, \mathrm{H}$, length $5.6 \mathrm{~mm}$, I, length $4.5 \mathrm{~mm}$.

J, K, L, M, Lyrocardium aurantiacum (A. Adams \& Reeve, 1850). J-K, Ningaloo Marine Park, WA: WAM S78130, length $34.5 \mathrm{~mm}$. J, exterior of r.v., K, interior of r.v.; L-M, N. of Rosemary Island, WA: WAM S78055, length $29.4 \mathrm{~mm}$. L, exterior of I.V., M, interior of I.V.

N, O, P, Q, R, S, T, U, 'Laevicardium' lobulatum (Deshayes, 1855). N-O, Clerke Reef, WA: WAM S68164, height $9.8 \mathrm{~mm}$; $\mathrm{N}$, exterior of r.v., O, exterior of I.v., P, interior of r.v., Q, interior of I.v.; R-U, Negros Island, Philippines: NHMUK 1974135, syntypes. R-S, height $22.4 \mathrm{~mm}$, R, interior of r.v., S, exterior of I.v., T, height $19.6 \mathrm{~mm}$, exterior of I.V., U, height $20.1 \mathrm{~mm}$, exterior of I.v. 
2009). The same is the case for Cardium rubescens E.A. Smith, 1911, described from Christmas Island (NHMUK 1911.2.26-14-15, two syntypes, examined by the authors). With most specimens remaining much smaller than $10 \mathrm{~mm}$, and the vast majority of the faunal surveys undertaken in WA to date focussing on macromolluscs, it is likely that this species is more common on the shelf of northern WA than is presently known.

\section{Genus Lyrocardium Meek, 1876}

Lyrocardium Meek, 1876: 167 (as a subgenus of Laevicardium). Type species by subsequent designation (Dall, 1900: 1076): Cardium lyratum G.B. Sowerby II, 1840; Recent, Philippines, S.E. Negros, Dumaguette.

Amphicardium von Martens in Möbius, Richters \& von Martens, 1880: 324 (as a subgenus of Cardium). Type species by subsequent designation (Keen, 1937: 4-5): Cardium lyratum G.B. Sowerby II, 1840.

Divergicardium Dunker, 1882: 212 (as a subgenus of Cardium). Type species by subsequent designation: Cardium lyratum G.B. Sowerby II, 1840.

\section{Lyrocardium aurantiacum \\ (A. Adams \& Reeve, 1850)}

Figures 7J-M, 19B

Cardium aurantiacum A. Adams \& Reeve, 1850: 77, pl. 22 fig. 4.

Lyrocardium aurantiacum (A. Adams \& Reeve, 1850) — Huber 2010: 306, fig.; ter Poorten 2011: pl. 1115 figs $3-4$.

Not: Nemocardium (Lyrocardium) aurantiacum (Adams \& Reeve, 1850) — Lamprell and Healy 1998: 244, fig. 740 (= L. lyratum).

\section{MATERIAL EXAMINED}

Australia: Western Australia: North West Shelf, Dampier Archipelago, 33 nautical miles N. of Rosemary Island, 1955'S, $116^{\circ} 36^{\prime} \mathrm{E}, 58 \mathrm{~m}, 29.09 .1982$. Leg. L.M. Marsh (WAM S78055, 1 s.v.); Pilbara Offshore, Off Onslow L19, $20^{\circ} 12^{\prime} 14.76^{\prime \prime S}, 115^{\circ} 8^{\prime} 20.75^{\prime \prime E}$ to $20^{\circ} 12^{\prime} 8.28^{\prime \prime} \mathrm{S}, 115^{\circ} 8^{\prime} 15.71 " \mathrm{E}, 100 \mathrm{~m}, 11.06 .2007$. Leg. C. Whisson, CSIRO RV 'Southern Surveyor' Cruise, Stn SS0507/018 (WAM S32871, 1 s.v.); Murion Islands, S. Muiron Island, off N.W. coast, $21^{\circ} 39.81^{\prime} S, 114^{\circ} 20.15^{\prime} \mathrm{E}$, 12-15 m, 15.08.1995. Leg. S.M. Slack-Smith et al., WAM Muiron Islands Exped. 1995, Stn 1 (WAM S78131, 1 s.v.); Ningaloo, Mandu Creek, 226'30"S, 11350'43"E to $22^{\circ} 6^{\prime} 26^{\prime \prime} \mathrm{S}, 113^{\circ} 50^{\prime} 43^{\prime \prime} \mathrm{E}, 73 \mathrm{~m}, 16.08 .2008$. Leg. O. Gomez \& J. Colquhoun, AIMS-WAM RV 'Cape Ferguson' Ningaloo Survey IV 08/09.2008, Stn SOL4769/2008/1-005SL02 (WAM S78130, 1 s.v.); Ningaloo Marine Park, off Osprey Sanctuary Zone, $22^{\circ} 18.263^{\prime} \mathrm{S}, 113^{\circ} 46.544^{\prime} \mathrm{E}$ to $22^{\circ} 18.505^{\prime} \mathrm{S}$, $113^{\circ} 46.157^{\prime} \mathrm{E}, 55 \mathrm{~m}, 25.04 .2006$. Leg. M.P. Salotti, AIMS-WAM RV 'Cape Ferguson' Ningaloo Survey I, Stn CF4010\&11/2006/D005 (WAM S78132, 1 s.v.)

\section{DESCRIPTION}

Shell medium sized (L 30-45 mm), rather thin, slightly inequilateral, obliquely rounded and rather inflated. Shell surface glossy. Margins rounded, central part of posterior margin almost straight. Margins finely crenulate, posterior margin smooth. Anterior part covered with widely spaced oblique ridges, median part with very faint radial riblets, posterior part smooth. Lunular heart with well raised dorsal margin, thickened on both valves. Exterior colour cream or with orange streaks and zigzag patterns, darker on posterior slope. Lunule and escutcheon pink or purple. Interior cream, pink or yellowish with darker posterior zone and umbonal cavity.

\section{DISTRIBUTION AND ECOLOGY}

The presence of $L$. aurantiacum in northern WA waters is confirmed by several specimens, all dead collected in 12-100 metres depth. All WA material has been found in a relatively small area off the Pilbara and Ningaloo coasts (Figure 19B), adding to the relatively high bivalve diversity in the Pilbara (Wilson 2013: table 8.4). Its presence in QLD is confirmed by several samples (NTM and TP). It is widely distributed in the Central IWP. The few available live records are from a depth range of 10-30 metres.

\section{REMARKS}

Wilson and Stevenson (1977) were well aware of the existence of this species, but at that time (mid 1970s) had only Indonesian material in the WAM collections at their disposal. The specimen figured by Lamprell and Healy (1998: fig. 740) refers to L. lyratum from Exmouth Gulf and is in the reference collection of the first author (TP 1461)

\section{Subfamily Fraginae Keen, 1951}

\section{REMARKS}

Clade C of Herrera et al. (2015) contains subclade 4 with Fragum, Corculum and Lunulicardia as well as Microfragum erugatum; whereas the type species of Microfragum (Cardium festivum) is placed in subclade 3, together with Ctenocardia and several American genera (Trigoniocardia, Apiocardia and Americardia). In the present study, M. erugatum is placed in Fragum (see above, under 'Comments on Wilson and Stevenson (1977) taxa'). 


\section{Genus Corculum Röding, 1798}

Corculum Röding, 1798: 188. Type species by subsequent designation (von Martens, 1870: 586): Cardium cardissa Linnaeus, 1758; Recent, 'O. Asiatico' (Indo-West Pacific).

Cardissa Megerle von Mühlfeld, 1811: 52. Type species by monotypy: Cardissa alba Megerle von Mühlfeld, 1811; Recent (type locality not mentioned).

Hemicardium Schweigger, 1820: 707. Type species by original designation: Cardium cardissa Linnaeus, 1758.

Cardissa Swainson, 1840: 373. Type species by monotypy: Cardissa spinosa Swainson, 1840; Recent (type locality not mentioned).

\section{Corculum cardissa (Linnaeus, 1758)}

Figures 9M-T, 18A

Cardium cardissa Linnaeus, 1758: 678.

Cardium dionaeum Broderip \& G.B. Sowerby I, 1829: 367.

Cardium unimaculatum G.B. Sowerby I in Broderip \& G.B. Sowerby I, 1833: 84-85.

Cardium productum Deshayes, 1855: 333 (non J. Sowerby in Sedgwick \& Murchison, 1835).

Corculum kirai Shikama, 1964: 75, figs 137 (15, 16), 138 (8).

Corculum dionaeum (Broderip \& Sowerby, 1829) Lamprell and Whitehead 1992: pl. 31 fig. 209.

Corculum cardissa (Linnaeus, 1758) - ter Poorten 2009: pl. 10 figs 1-3; Huber 2010: 299, fig.; ter Poorten 2011: pl. 1099 figs 1-7, pl. 1100 figs 1-8.

\section{MATERIAL EXAMINED}

Australia: Western Australia: Oceanic Shoals, Cartier Reef, $12^{\circ} 31.8^{\prime} \mathrm{S}, 123^{\circ} 33.3^{\prime} \mathrm{E}$, found on strand line of small sand cay, 05.05.1992. Leg. R.C. Willan (NTM P.222, 11 s.v.); Rowley Shoals, Mermaid Reef, W. side, $17^{\circ} 04^{\prime} 42^{\prime \prime S}, 119^{\circ} 36^{\prime} 07^{\prime \prime} \mathrm{E}, 0 \mathrm{~m}, 26.07 .1982$. Leg. WA Museum Party, WAM Rowley Shoals Exped. 1982, Stn 10 (WAM S39933, 1 s.v.); Clerke Reef,

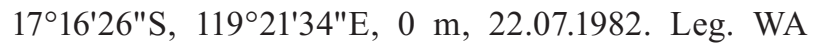
Museum Party, WAM Rowley Shoals Exped. 1982, Stn 15 (WAM S39932, 3 s.v.); S.W. end, 17²2'28"S, $119^{\circ} 20^{\prime} 34 " \mathrm{E}, 1 \mathrm{~m}, 24.07 .1982$. Leg. WA Museum Party, WAM Rowley Shoals Exped. 1982, Stn F (WAM
S39931， 1 s.v.); $17^{\circ} 09^{\prime} 35.169$ "S, $11^{\circ} 13^{\prime} 00.414$ "E, 0-3 m, 03.10.2014. Leg. C. Bryce, Woodside Kimberley Survey 2014, Stn Bedwell Is Shallow/K14 (WAM S95391, 2 s.v.); E. reef S. of channels, $17^{\circ} 20^{\prime}$ S, $119^{\circ} 10^{\prime} \mathrm{E}$ (WAM S39934, 1 s.v.); Clerke Reef, unknown lat./ long., 03.10.2014. Leg. C. Bryce, Woodside Kimberley Survey 2014, Stn Bedwell Is/K14 (WAM S95388, 3 s.v.); Imperieuse Reef, $17^{\circ} 30^{\prime} 32.938^{\prime \prime S}, 118^{\circ} 57^{\prime} 47.368^{\prime \prime} \mathrm{E}$, 15 m, 06.10.2014. Leg. C. Bryce, Woodside Kimberley Survey 2014, Stn 160/K14 (WAM S68263, 2 p.v., A); $17^{\circ} 30^{\prime} 20.627^{\prime \prime S}, 118^{\circ} 57^{\prime} 45.802 " E, 0$ m, 09.10.2014. Leg. C. Bryce, Woodside Kimberley Survey 2014, Stn 166/ K14 (WAM S68277, 1 p.v., A).

\section{DESCRIPTION}

Shell medium to large (H 35-70 mm), rather thin and glassy, inequilateral with anterior slope more expanded than posterior which becomes ventrally concave; shell tumid and excessively flattened, extremely reduced in length; presence of an acute, ridged to spinose radial keel; in anterior and posterior views the shell looks like a stylised heart. Between 12-18 flattened radial ribs on each slope, bearing tubercles, sometimes slightly ridged; interstices smooth. Antero-dorsal margin not touching umbo, slightly depressed in front of it; posterior part of hinge with an extremely short nymphal plate and ligament, but a long escutcheon zone. Colour extremely variable: white, lemon-yellow, pink, orange, brown, sometimes with radially aligned purple stripes on the lighter background.

\section{DISTRIBUTION AND ECOLOGY}

So far exclusively reported from the oceanic emergent reefs of northern WA where it was found in shallow water or intertidally (Wells and Slack-Smith 1986; Willan 2005; Figure 18A). Corculum cardissa is a somewhat uncommon and cryptic species of the northern oceanic shoals, found in the shallow intertidal of clear, rubbly coral reef habitats. This species has been reported from QLD (Lamprell and Whitehead 1992) but not in NT. It has a wide distribution in the IWP.

\section{REMARKS}

The shell morphology of the WAM specimens, many are juveniles, is in agreement with $C$. cardissa, under study at the WAM to test species boundaries (ter Poorten 2009; Huber 2013). It is a member of the photosymbiotic fragines, a wholly photosymbiotic lineage of cardiids (Kirkendale and Paulay 2017). However, unlike many other closely related photosymbiotic species, $C$. cardissa is essentially a dorsoventrally flattened 'living' solar panel with transparent shell microstructural windows that facilitate light penetration through the shell (Carter and Schneider 1997). 


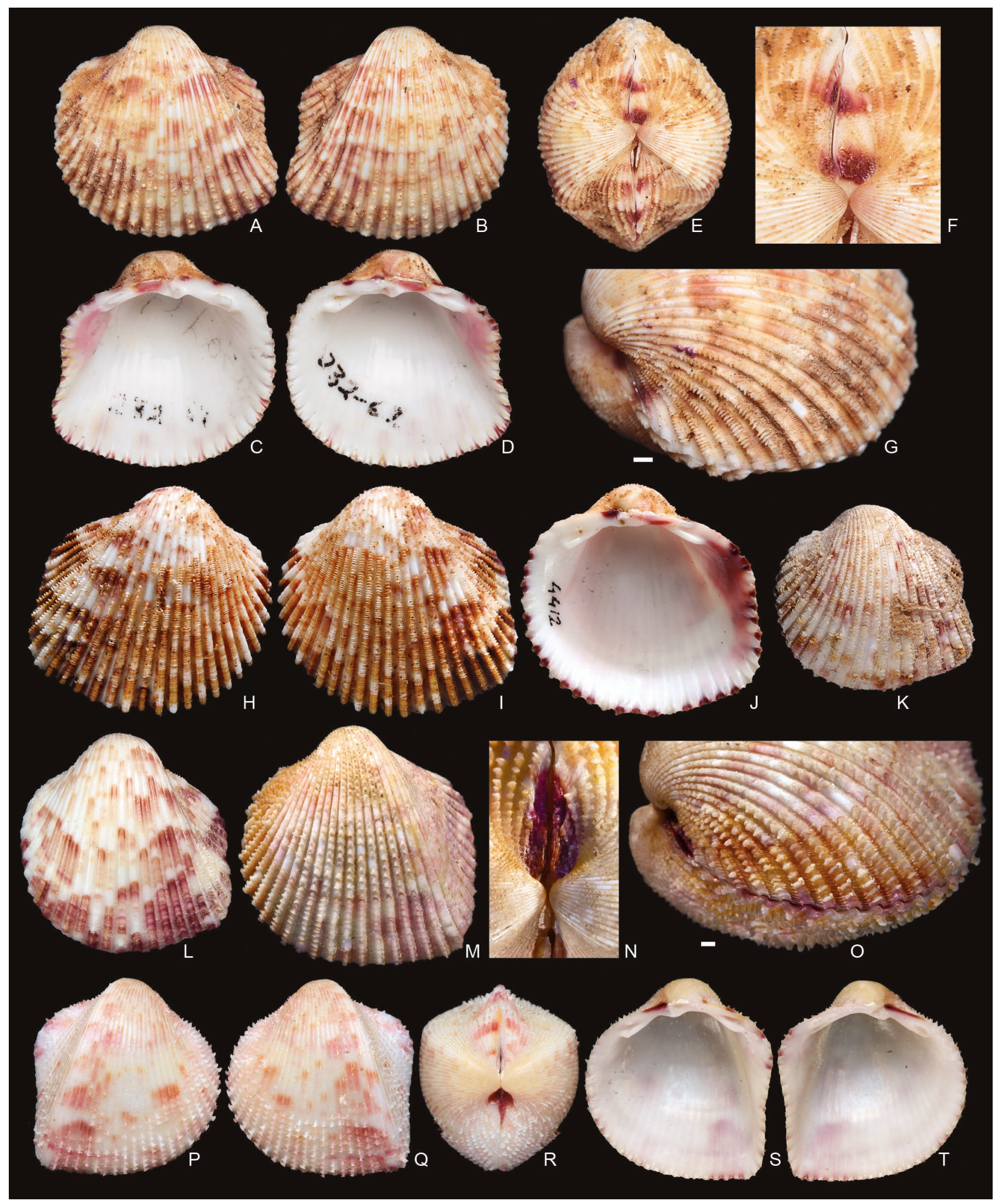

FIGURE 8 A, B, C, D, E, F, G, H, I, J, K, L, Ctenocardia pilbaraensis sp. nov. A-G, near Onslow, WA: WAM S78025, holotype, length $19.8 \mathrm{~mm}$. A, exterior of I.V., B, exterior of r.V., C, interior of I.V., D, interior of r.V., E, dorsal, F, asymmetrical lunular area, G, anterior slope of I.v.; H-J, off Onslow, WA:TP 4412, paratype, length $28.6 \mathrm{~mm}$. $\mathrm{H}$, exterior of r.V., I, exterior of I.V., J, interior of r.v.; K, Dampier Arch., WA: WAM S22828, paratype, length 19.5 mm, exterior of I.v.; L, 'N. Sabah, Malaysia': TP 3286, height 23.6 mm, exterior of I.V.

M, N, O, P, Q, R, S, T, Ctenocardia fornicata (G.B. Sowerby II, 1840). M-O, unknown provenance: NHMUK 1996513, largest of the four possible syntypes, height $26.7 \mathrm{~mm}$. M, exterior of I.v., N, symmetrical lunular area, O, anterior slope of I.v.; P-T, Scott Reef, WA: WAM S39930, length $15.3 \mathrm{~mm}$. P, exterior of r.v., Q, exterior of I.v., R, dorsal, S, interior of r.v., T, interior of I.v. Scale bars: $1 \mathrm{~mm}$. 


\section{Genus Ctenocardia H. Adams \& A. Adams, 1857}

Ctenocardia H. Adams \& A. Adams, 1857: 459 (as a subgenus of Hemicardia). Type species by subsequent designation (Dall, 1900: 1075): Cardium hystrix Reeve, 1844 (non Lightfoot, 1786) [= Fragum (Ctenocardia) symbolicum Iredale, 1929; nom. nov. for Cardium hystrix Reeve, 1844]; Recent, Corrigidor Isl., Philippines, c. 7 fms $[13 \mathrm{~m}]$.

\section{Ctenocardia fornicata (G.B. Sowerby II, 1840)}

\section{Figures $8 \mathrm{M}-\mathrm{T}$}

Cardium fornicatum G.B. Sowerby II, 1840a: figs 50, 50a; 1840b: 7, sp. 84; 1841: 110 .

Cardium adamsii Reeve in A. Adams \& Reeve, 1850: 77, pl. 22 fig. 2.

Ctenocardia (Ctenocardia) fornicata (Sowerby, 1840) Lamprell and Whitehead 1992: pl. 32 fig. 211.

Ctenocardia fornicata (G.B. Sowerby II, 1840) - ter Poorten 2009: pl. 10 figs 7-10; Huber 2010: 300, fig.; ter Poorten 2011: pl. 1101 figs 4-6.

Not: Ctenocardia fornicata (Sowerby, 1841) - Wilson and Stevenson 1977: 28-30, pl. 4 figs 10-13, text fig. 2.

\section{MATERIAL EXAMINED}

Australia: Western Australia: Oceanic Shoals, N.

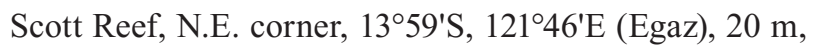
in rubble, 09.1996. Leg. H. Morrison, WAM Offshore Kimberley Survey 1996 (WAM S39930, 1 p.v.).

\section{DESCRIPTION}

Shell medium sized (L 20-39 mm), rather solid, well-inflated, inequilateral and quadrate, height approximately equals length. Umbonal keel strongly angled, anterior and ventral margin rounded, posterior margin straight or slightly concave. Between 37-44 squarish radial ribs with elaborate ornamentation on shell anterior, i.e. erect top spines or spinose scales and small bilateral spines; posteriorly likewise but often less well developed, occasionally ribs bearing only imbricated lamellae. Interstices narrow, finely striated. Lunule well delimited, similar sized in both valves. Exterior colour cream, mottled with brown-red, lunule purple; interior reflects exterior by translucency, white often suffused with yellow, orange or pink.

\section{DISTRIBUTION AND ECOLOGY}

The only WA record is from Scott Reef, part of the oceanic reefs of the outer shelf margin, where it was found sympatric with $C$. gustavi. In contrast, all other
Ctenocardia samples of the continental coastal waters of northern WA proved to be C. pilbaraensis sp. nov., as were all Wilson and Stevenson (1977) records of $C$. fornicata. This species has a wide IWP distribution and has been live recorded from 15-80 metres depth (based on 24 samples).

\section{REMARKS}

The single recorded specimen has 41 ribs (range 3744). Material under this name is reported by Lamprell and Whitehead (1991) from northern WA, but it is not clear which Ctenocardia species is involved: the given rib number (32-42) suggests a composite of $C$. fornicata and $C$. pilbaraensis sp. nov. records. The largest of the four possible syntypes of $C$. fornicata (NHMUK 1996513, H $26.7 \mathrm{~mm}$ ) is figured for comparison (Figures 6M-O). Examination of the holotype of Cardium adamsii Reeve in A. Adams \& Reeve, 1850 (NHMUK 1874.12.11.391) and comparison with the possible syntypes of $C$. fornicata has confirmed its synonymy.

\section{Ctenocardia gustavi Vidal \& Kirkendale, 2007}

Figures $9 A-D, 18 B$

Ctenocardia gustavi Vidal \& Kirkendale, 2007: 98-100, figs $5 \mathrm{e}-\mathrm{g}$.

Ctenocardia gustavi Vidal \& Kirkendale, 2007 - ter Poorten 2009: pl. 8 fig. 6, pl. 10 figs 4-6; Huber 2010: 300, fig.; ter Poorten 2011: pl. 1101 figs 1-3.

\section{MATERIAL EXAMINED}

Australia: Western Australia: Oceanic Shoals, Hibernia Reef, N. side, reef slope, immediately outside entrance to lagoon, $11^{\circ} 57.8^{\prime} \mathrm{S}, 123^{\circ} 22.3^{\prime} \mathrm{E}, 8-12 \mathrm{~m}$, 10.05.1992. Leg. R.C. Willan (NTM P.13187, 1 s.v.); S.E. side, large pool in extensive reef flat, lagoon behind reef crest, $11^{\circ} 58.07^{\prime} \mathrm{S}, 123^{\circ} 22.08^{\prime} \mathrm{E}, 5 \mathrm{~m}$, mixture of clean coral sand and Halimeda-algal sand, 12.05.1992. Leg. J.R. Hanley (NTM P.23197, 1 p.v., A); Ashmore Reef, lagoon, $12^{\circ} 13^{\prime} 50.34^{\prime \prime S}, 122^{\circ} 59^{\prime} 59.918^{\prime \prime E}, 12 \mathrm{~m}$, 25.09.2013. Leg. L. Kirkendale \& C. Bryce, Woodside Kimberley Survey 2013, Stn 122/K13 (WAM S75035, 1 p.v., A); N. Scott Reef, W. side lagoon 1357'59"S, 121 ${ }^{\circ} 52^{\prime} 24 " E, 6-18$ m, 11.09.1984. Leg. F. Wells \& C. Bryce, WAM Scott / Seringapatam Reefs Survey 1984, Stn 8 (WAM S39929, 1 s.v.).

\section{DESCRIPTION}

Shell small to medium (L 15-25 mm), rather solid, well-inflated, inequilateral and quadrate. Umbonal keel strongly angled with concave posterior slope. Between 39-45 low flattened radial ribs carrying minute, densely placed and strongly arched lamellae of variable strength, becoming more pronounced near anterior and posterior 
margins. Interstices narrow. Lunule present but small. Exterior cream with irregularly placed pale purple and yellowish spots. Small orange blotches on lunule and the most posterior rib(s). Interior variable, often white or with purple to orange umbonal ray on posterior quarter, sometimes with two reddish-brown rays.

\section{DISTRIBUTION AND ECOLOGY}

All WA samples of this species originate from the northern offshore reefs, indicating a strong biogeographic affinity with the IWP (Figure 18B). This is also true for the Kimberley record by Willan et al. (2015), from a project area that includes Hibernia Reef. The occurrence in WA is well established by the two live-collected specimens, found in 5-12 metres depth, which aligns with the presently known shallow water occurrence. The distribution covers the Central IWP.

\section{Ctenocardia pilbaraensis sp. nov. ter Poorten \& Kirkendale}

Figures 8A-L, 18C, Table 2

urn:Isid:zoobank.org:act:655623C1-D53C-4D24-BEA40C19749C59B2

? Trigoniocardia adamsi (Adams \& Reeve, 1850) Habe and Kosuge 1970: 153, pl. 59 fig. 3.

Ctenocardia fornicata (Sowerby, 1841) - Wilson and Stevenson 1977: 28-30, pl. 4 figs 10-13, text fig. 2.

Ctenocardia fornicata (Sowerby, 1840) - Slack-Smith and Bryce 2004: 238; Taylor and Glover 2004: 263.

Ctenocardia fornicata (G.B. Sowerby, 1840) — Willan et al. 2015: 336 [pars].

\section{MATERIAL EXAMINED}

\section{Holotype}

Australia: Western Australia: Pilbara Nearshore/ Offshore, near Onslow, W. side of Peak Island [2136'5"S, 114³0'34"E], 10 fms (18 m), 18.06.1960, Western Australian Hawaiian Exped. (WAM S78025, ex 232-67, 1 p.v.).

\section{Paratypes}

Australia: Western Australia: Pilbara Nearshore/ Offshore, 38 nautical miles N. of Port Walcott, $19^{\circ} 59^{\prime} \mathrm{S}$, $117^{\circ} 16^{\prime} \mathrm{E}$ to $20^{\circ} 01^{\prime} \mathrm{S}, 117^{\circ} 16^{\prime} \mathrm{E}, 50-52 \mathrm{~m}, 15.04 .1982$. Leg. L.M. Marsh, CSIRO FRV 'Soela' Cruise II 1982, Stn S02/82/54A (WAM S29235, 1 p.v., A, paratype); Dampier Archipelago, approx. 0.4 nautical miles W. of N.W. point of Goodwyn Island, $20^{\circ} 32.11^{\prime} \mathrm{S}, 116^{\circ} 31.55^{\prime} \mathrm{E}$ to $20^{\circ} 32.40^{\prime} \mathrm{S}, 116^{\circ} 31.22^{\prime} \mathrm{E}, 13-15 \mathrm{~m}$, coarse shelly sand, 25.07.1999. Leg. J.D. Taylor \& E.A. Glover, Woodside Dampier Exped. II 1999, Stn DA2/99/76 (WAM S22828,
1 p.v., A, paratype); Dampier Archipelago, 42-43 m. Woodside Dampier Exped. II, 07.1999 (MNHNIM-2014-5525, 3 s.V., paratypes); off Onslow, dived, 2025 m, c. 2010 (TP 4412, 1 p.v., paratype); near Onslow, W. side of Peak Island [21 $\left.36^{\prime} 5^{\prime \prime S}, 114^{\circ} 30^{\prime} 34^{\prime \prime E}\right], 10 \mathrm{fms}$ (18 m), 18.06.1960, Western Australian Hawaiian Exped. WAM S67900, 4 p.v., 1 s.v., paratypes); Exmouth Gulf, off Exmouth Town Beach (Yacht Club), 34' (10 m), silty sand \& shells, 15.08.1989. Leg. S.M. Slack-Smith \& A. East (WAM S78108, 1 p.v., paratype).

\section{Other materials}

Malaysia: Sabah: N. point, channel between Banggi Island and mainland of Sabah [ca $\left.7^{\circ} \mathrm{N}, 117^{\circ} \mathrm{E}\right]$, dived, 10.2006. Leg. H. Morrison (TP 3286, 1 p.v.).

Australia: Western Australia: Canning, Lacepede Archipelago, W. of Lacepede Island, $16^{\circ} 52^{\prime} \mathrm{S}, 122^{\circ} 09^{\prime} \mathrm{E}$ (Egaz), 48 m, 22.12.1969. Leg. K. Ozawa, Tokyo University of Fisheries Exped. FV 'Umataka Maru', 1969, Stn UMD6928 (WAM S57168, 2 s.v.); North West Shelf, Rowley Shoals, off Mermaid Reef, 1746' $6.23^{\prime \prime S}$, $120^{\circ} 43^{\prime} 9.12^{\prime \prime} \mathrm{E}$ to $17^{\circ} 45^{\prime} 56.87^{\prime \prime S}, 120^{\circ} 42^{\prime} 56.51^{\prime \prime} \mathrm{E}, 97-109$ m, 20.06.2007. Leg. C. Whisson \& O. Gomez, CSIRO RV 'Southern Surveyor' Cruise, Stn SS0507/097 (WAM S32854, 1 s.v.); Oceanic Shoals, Imperieuse Reef, $17^{\circ} 36^{\prime} \mathrm{S}, 118^{\circ} 56^{\prime} \mathrm{E}$ (Egaz), 10.1974. Leg. E. Little (WAM S57002, ex 672-75, 1 s.v.); Pilbara Nearshore/Offshore, Dampier Archipelago, 2 miles W. of Legendre Island, $23 \mathrm{fms}$ (42 m), sponge and rubble, 09.06.1960, Western Australian Hawaiian Exped. (WAM S78030, ex 23567, 1 s.v., SEM coated specimen); N. of Nelson Rocks, $20^{\circ} 26.511^{\prime} \mathrm{S}, 116^{\circ} 40.256^{\prime} \mathrm{E}$ (Egaz), 6-24 m, 07.09.1999. Leg. S.M. Slack-Smith et al., Woodside Dampier Exped. III 1999, Stn DA3/99/67 (WAM S22444, 1 s.v.); 33 nautical miles N. of Rosemary Island, $19^{\circ} 55^{\prime} \mathrm{S}, 116^{\circ} 36^{\prime} \mathrm{E}$, $58 \mathrm{~m}$, shell \& gravel, 29.09.1982. Leg. L.M. Marsh \& M. Bezant on 'Soela', Stn S05/82/27A (WAM S78032, 2 s.v.); N. of Enderby Island, $19^{\circ} 50^{\prime} \mathrm{S}, 116^{\circ} 27^{\prime} \mathrm{E}$ to $19^{\circ} 52^{\prime} \mathrm{S}$, $116^{\circ} 28^{\prime} \mathrm{E}, 65-70 \mathrm{~m}, 04.12 .1979$. Leg. S.M. Slack-Smith \& L.M. Marsh on 'Soela', CSIRO \# 001/0026\&0027 (WAM S78031, 1 s.v.); Enderby Island, S.W. of Rocky Head, 20³7.111'S, 116 26.780'E (Egaz), 13-15 m, 06.09.1999. Leg. S.M. Slack-Smith et al., Woodside Dampier Exped. III 1999, Stn DA3/99/65 (WAM S22441, 1 s.V.); E.S.E. of Montebello Island, $20^{\circ} 39^{\prime} \mathrm{S}, 115^{\circ} 58^{\prime} \mathrm{E}$ to $20^{\circ} 39^{\prime} \mathrm{S}$, $116^{\circ} 01^{\prime} \mathrm{E}, 27-29 \mathrm{~m}, 02.12 .1979$. Leg. S.M. Slack-Smith \& L.M. Marsh on 'Soela', CSIRO \# 001/0004-0005 (WAM S78028, 1 s.v.); E. side of Pasco Island, $20^{\circ} 58^{\prime} \mathrm{S}$, $115^{\circ} 20^{\prime} \mathrm{E}$, dredged, 1-2 fms (2-4 m), sand with some coral-heads, 02.09.1966. WAM-USNM Barrow Island, WA Exped. 1966, Stn 9 (WAM S78029, ex 258-67, 1 s.v.); Onslow, N. of Long Island, W. of Flat Island, 6-10 fms (11-18m), 19.06.1960, Western Australian Hawaiian Exped. (WAM S78024, 1 p.v., A); 7 miles N. of Long Island, $28 \mathrm{fms}$ (51 m), fine sand and rubble, 17.06.1960, Western Australian Hawaiian Exped. (WAM S78129, 1 p.v., A); S. Muiron Island, off N.W. coast, $21^{\circ} 39.86^{\prime}$ S, $114^{\circ} 20.06^{\prime}$ E, 13-15 m, 25.08.1995. Leg. S.M. SlackSmith et al., Stn 14 (WAM S78027, 1 s.v.); off W. coast, 


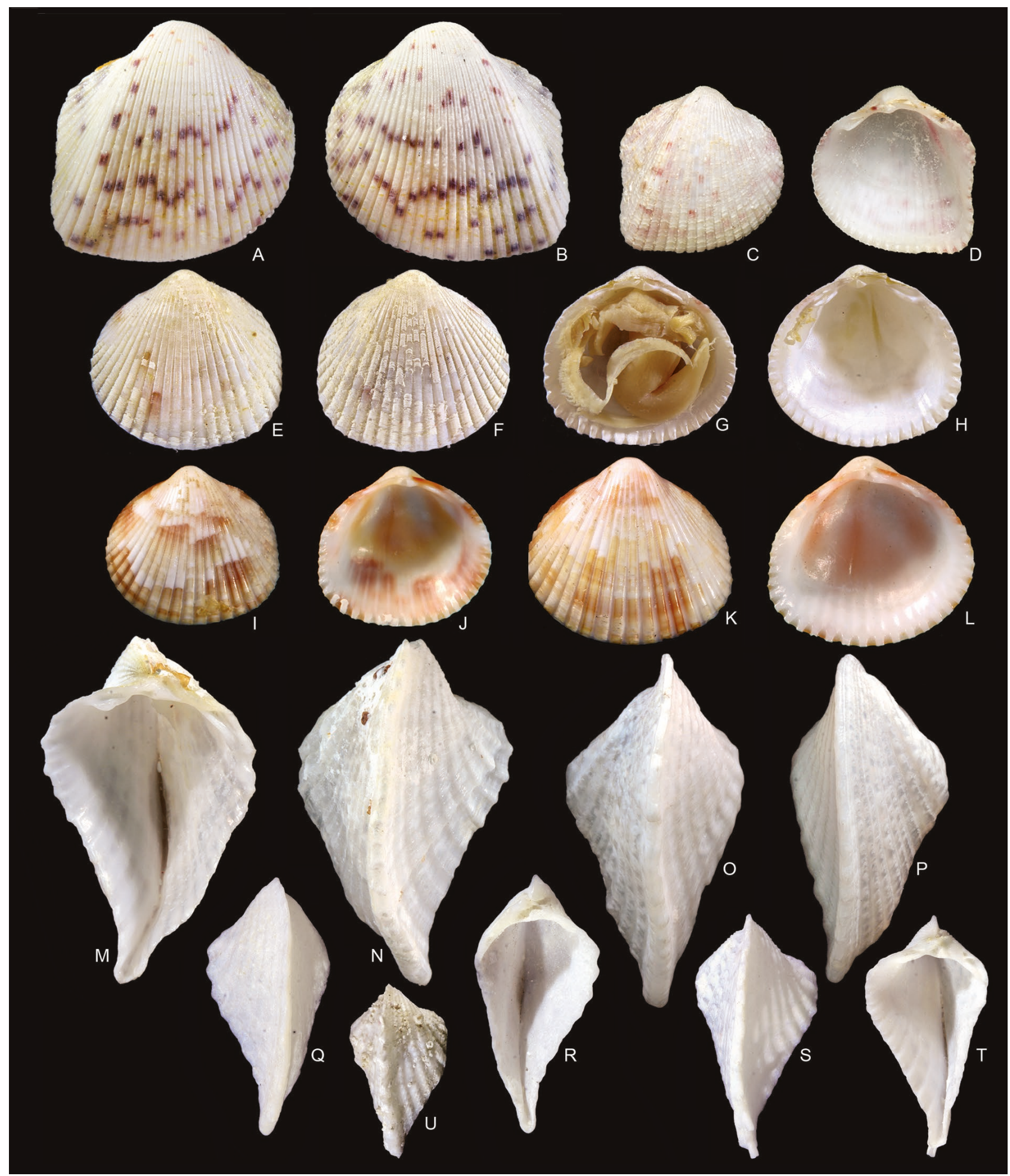

FIGURE 9 A, B, C, D, Ctenocardia gustavi Vidal \& Kirkendale, 2007. A-B, Ashmore Reef, WA: WAM S75035, length $17.0 \mathrm{~mm}$. A, exterior of r.V., B, exterior of I.v.; C-D, Scott Reef, WA: WAM S39929, length 10.3 mm; C, exterior of r.v., D, interior of r.v.

E, F, G, H, I, J, K, L, Microfragum festivum (Deshayes, 1855). E-H, Clerke Reef, WA: WAM S40376, length $11.6 \mathrm{~mm}$. E, exterior of I.v., F, exterior of r.V., G, interior of I.v., H, interior of r.v.; I-L, 'New Ireland' [Papua New Guinea, Bismarck Arch.]: NHMUK 1974134, syntypes. I-J, length 9.4 mm, I, exterior of I.v., J, interior of I.v., K-L, length $11.2 \mathrm{~mm}$, K, exterior of I.V., L, interior of I.v.

M, N, O, P, Q, R, S, T, Corculum cardissa (Linnaeus, 1758). M-P, Cartier Reef, WA: NTM P.222. M-N, height $33.5 \mathrm{~mm}, \mathrm{M}$, interior of r.v., $\mathrm{N}$, exterior of r.v., O, height $32.8 \mathrm{~mm}$, exterior of I.v., $\mathrm{P}$, height $31.2 \mathrm{~mm}$, exterior of r.v.; Q-T, Clerke Reef, WA: WAM S39932. Q-R, height $22.0 \mathrm{~mm}$, Q, exterior of I.V., R, interior of I.V. S-T, H 20.7 mm, S, exterior of r.V., T, interior of r.V.; U, Mermaid Reef, WA: WAM S39933, height $14.9 \mathrm{~mm}$, exterior of r.v. 
$21^{\circ} 40.58^{\prime} \mathrm{S}, 114^{\circ} 19.12^{\prime} \mathrm{E}, 17-18 \mathrm{~m}, 20.08 .1995$. Leg. S.M. Slack-Smith et al., Stn 3 (WAM S78026, 1 s.v.); Ningaloo, Ningaloo Marine Park, Vlamingh Head, $21^{\circ} 46.903^{\prime} \mathrm{S}, 114^{\circ} 03.348^{\prime} \mathrm{E}$ to $21^{\circ} 46.806^{\prime} \mathrm{S}, 114^{\circ} 03.355^{\prime} \mathrm{E}$, 38-39 m, 03.05.2007. Leg. M.P. Salotti, AIMS RV 'Cape Ferguson' Ningaloo Survey II, Stn CF4314/2007/ D053 (WAM S78022, 1 s.v.); $21^{\circ} 48^{\prime} 15^{\prime \prime S}, 114^{\circ} 0{ }^{\prime} 45^{\prime \prime E}$ to $21^{\circ} 48^{\prime} 14 " \mathrm{~S}, 114^{\circ} 0{ }^{\prime} 46^{\prime} \mathrm{E}$ (GPS), 45-50 m, rubble, sponges, etc., 12.02.2008. Leg. S.M. Slack-Smith, AIMS RV 'Solander' Cruise, Stn RVS4545-D144 (WAM S43495, 1 p.v.); S. of Vlaming Head, 08.1975. Leg. J. Hewitt (WAM S78023, 1 s.v.); off Osprey Sanctuary Zone, $22^{\circ} 18.263^{\prime}$ S, $113^{\circ} 46.544^{\prime} \mathrm{E}$ to $22^{\circ} 18.505^{\prime} \mathrm{S}, 113^{\circ} 46.157^{\prime} \mathrm{E}, 55 \mathrm{~m}$, coarse sand, 25.04.2006. Leg. M.P. Salotti, AIMS RV 'Cape Ferguson' Ningaloo Survey I, Stn CF4010\&11/2006/ D005 (WAM S78021, 1 s.v.); Zuytdorp, Shark Bay, N. of Dirk Hartog Island, 2550'32.0"S, 11303'24.0"E, 40 fms $(73 \mathrm{~m})$, on sand bottom, 15.05.1960. Ex coll. King, WAM Mariel King Hawaiian Exped., MV 'Davena' 1960 (WAM S78046, 1 s.v.).

Unknown provenance: (TP 2942, 1 p.v.).

\section{DESCRIPTION}

Shell medium sized (L up to $28.5 \mathrm{~mm}$ ), solid, inequilateral, quadrate, inflated, height about equal to length (mean $\mathrm{L} / \mathrm{H}$ ratio $1.02, \mathrm{n}=10$, Table 2). Anterior and ventral margin rounded, postero-ventral corner angulate, posterior margin clearly to strongly concave. Umbonal keel strongly angled. Between 32 to 38 well developed radial ribs (mean rib number 35.2, $\mathrm{n}=10$, Table 2), anteriorly carrying projecting densely placed scales, of which the antero-dorsal ones are often broader than the ribs, gradually ventrally and posteriorly becoming more tubular spiny, slightly hollow ventrally. Rib sculpture easily wearing off, resulting in glossy ribs. Rib sides generally finely bi-sculptured with crowded, tiny ridges. Margins crenulated, rib impressions slightly extending into the shell. Interstices approximately half as wide as the ribs, ornamented with fine concentric striae. Lunule asymmetric: much larger in right valve, carrying between 10-12 finely sculptured riblets of irregular strength, in left valve smooth or indistinctly sculptured. Escutcheon poorly defined. Hinge plate nearly straight, hinge strong, right valve with two very unequal cardinal teeth, ventral one large and pointed, dorsal one small, teeth partly joint by dorsal saddle. Two right anterior and two right posterior laterals, approximately equidistant from cardinals, ventral ones much stronger. Left valve with two cardinals, one anterior and one posterior lateral tooth. Exterior white or cream with irregular brown or purple patches, lunule cream with one or two patches of deep purple; interior white or pale pink with pink to purple spot near posterior margin; hinge plate white except for purple spot below ligament and occasionally below lunule. Periostracum not observed.

\section{REMARKS}

Differs from $C$. fornicata by its smaller dimensions (L 20-28.5 mm), thicker shell, lower rib number (32-38 ribs, minute ribbing on lunule excluded), very crowded rib sculpture on the antero-dorsal slope, asymmetric lunule (much larger in right valve, Figure $8 \mathrm{~F}$ ), generally stronger concave posterior margin and much less colourful shell interior.

TABLE 2 Shell measurements of Ctenocardia pilbaraensis sp. nov. Width includes rib sculpture; not measured on worn material and loose valves.

\begin{tabular}{lccccc} 
Sample & Height $(\mathrm{mm})$ & Length $(\mathrm{mm})$ & Width $(\mathrm{mm})$ & Ribs & L/H ratio \\
\hline WAM S78025 (holotype) & 19.0 & 19.8 & 15.7 & 36 & 1.04 \\
WAM S67900 (paratype) & 18.0 & 19.1 & 15.7 & 34 & 1.06 \\
WAM S29235 (paratype) & 10.0 & 10.1 & 7.9 & 34 & 1.01 \\
WAM S43495 & 18.5 & 18.6 & 14.3 & 35 & 1.01 \\
WAM S78021 & 21.7 & 21.5 & - & 37 & 0.99 \\
WAM S78022 & 20.0 & 19.6 & - & 38 & 0.98 \\
WAM S78031 & 25.3 & 24.3 & - & 37 & 0.96 \\
WAM S78108 (paratype) & 17.7 & 19.0 & 15.3 & 33 & 1.07 \\
TP 4412 (paratype) & 27.7 & 28.5 & 22.5 & 34 & 1.03 \\
MNHN-IM-2014-5525 (paratype) & 19.0 & 20.0 & - & 34 & 1.05 \\
\hline Mean values & & & 35.2 & 1.02
\end{tabular}




\section{DISTRIBUTION AND ECOLOGY}

Sofar confined to northern WA. The presence of one Malaysian sample (Sabah, exact locality unknown, TP 3286, Figure 8L) suggests that it may not be an endemic WA species, however, additional material is needed for confirmation. Unlike C. fornicata and C. gustavi, this species is an inner continental or 'coastal' WA species with a depth range of 2-109 $\mathrm{m}$ (11-52 m alive) (Figure 18C). It is well established that there is a major separation between the molluscan faunas of the inner continental coast of WA and the offshore reefs (Willan 2005; Wilson 2013), and the fully allopatric distribution of Ctenocardia pilbaraensis sp. nov. compared to other WA Ctenocardia species offers additional corroboration for this idea. Habe and Kosuge (1970: pl. 59 fig. 3, as ?Trigoniocardia adamsi) depict a shell from unknown origin that looks very similar to the present species.

\section{ETYMOLOGY}

The specific epithet refers to the Pilbara, the area of the Australian North West Shelf where most of the type material has been found.

\section{Genus Fragum Röding, 1798}

Fragum Röding, 1798: 189. Type species by absolute tautonymy: Fragum flavum Röding, 1798 [= Cardium fragum Linnaeus, 1758]; Recent, 'O. Asiatico, Americano' (Indo-West Pacific; restricted to Ambon, Indonesia by Wilson and Stevenson 1977: 37).

Hemicardium Swainson, 1840: 373 (non Spengler, 1799; nec Schweigger, 1820). Type species by subsequent designation (J.E. Gray, 1847: 185): Cardium unedo Linnaeus, 1758; Recent (type locality not mentioned).

\section{Fragum mundum (Reeve, 1845)}

Figures 10A-L, 18D

Cardium mundum Reeve, 1845: sp. 125, pl. 22 fig. 125.

Cardium arcuatulum G.B. Sowerby III, 1874: 721, pl. 59 fig. 10 .

Fragum thurstoni Dall, Bartsch \& Rehder, 1938: 154155, pl. 41 figs 9-10.

Fragum mundum (Reeve, 1845) - ter Poorten 2009: pl. 7 figs 3-4, Huber 2010: 298, fig.; pl. 8 fig. 3; ter Poorten 2011: pl. 1097 figs 2-3.

\section{MATERIAL EXAMINED}

Australia: Western Australia: Oceanic Shoals, Cartier Reef, N.E. end of cay, large shallow pool adjacent to reef flat, $12^{\circ} 31.7^{\prime} \mathrm{E}, 123^{\circ} 33.5^{\prime} \mathrm{E}, 2.5-6 \mathrm{~m}$, on the undersurface of dead coral slabs, substrate of coarse coral sand with small pieces of unconsolidated coral rubble, 05.05.1992. Leg. R.C. Willan (NTM P.54210, 1 p.V., 1 s.v.); Ashmore Reef, Lower E. Side, $12^{\circ} 16^{\prime} 38.389^{\prime S}$, $123^{\circ} 08^{\prime} 09.935^{\prime \prime E}, 1$ m, 28.09.2013. Leg. L. Kirkendale \& C. Bryce, Woodside Kimberley Survey 2013, Stn 129/K13 (WAM S75212, 1 p.v.); Rowley Shoals, Clerke Reef, $17^{\circ} 23^{\prime} 15.758^{\prime \prime S}, 19^{\circ} 22^{\prime} 14.207^{\prime \prime E}$, 0 m, 10.10.2014. Leg. C. Bryce, Woodside Kimberley Survey 2014, Stn 169/K14 (WAM S95498, 1 p.v., A); $17^{\circ} 09^{\prime} 35.169^{\prime \prime S}, 119^{\circ} 13^{\prime} 00.414^{\prime \prime E}, 0-3 \mathrm{~m}, 03.10 .2014$. Leg. C. Bryce, Woodside Kimberley Survey 2014, Stn Bedwell Is Shallow/K14 (WAM S95389, 1 s.v.);

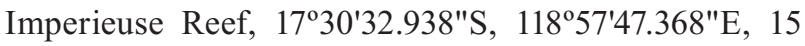
m, 06.10.2014. Leg. C. Bryce, Woodside Kimberley Survey 2014, Stn 160/K14 (WAM S58124, 1 p.v., A); $17^{\circ} 30^{\prime} 20.627^{\prime \prime S}, 118^{\circ} 57^{\prime} 45.802^{\prime \prime E}, 0$ m, 09.10.2014. Leg. C. Bryce, Woodside Kimberley Survey 2014, Stn 166/ K14 (WAM S58115, 9 p.v., A; WAM S58116, 1 p.v., A; WAM S58117, 1 p.v., A; WAM S58118, 1 p.v., A; WAM S58119, 1 p.v., A; WAM S58120, 1 p.v., A; WAM S95383, 4 s.v.); Pilbara Nearshore, Dampier Archipelago, Kendrew Island, $20^{\circ} 28^{\prime} 30^{\prime \prime S}, 116^{\circ} 32^{\prime} \mathrm{E}, 3$ m, 19.02.1973, Crown of Thorns Survey III Jan-Feb 1973, transect N1 (WAM S79509, 1 p.v.).

\section{DESCRIPTION}

Shell very small (H 5-12 mm), very inequilateral, rather solid, trapezoidal with rounded anterior margin and straight to slightly concave and serrate posterior margin. Posterior slope set off from the rest of the shell by a sharp radial angulation, forming a postero-ventral angle of approximately $65-80^{\circ}$. Between 26-30 radial ribs (of which 9-10 are on the posterior slope); ribs flat with more or less imbricate rather crowded scales on top, becoming spiny on the posterior slope. Interstices narrow, finely striated. Antero-dorsal margin not touching umbo, slightly depressed near it. Hinge plate broad, hook-shaped basement of the anterior lateral tooth. Exterior and interior cream to yellow (seldom with pinkish streaks posteriorly) with semi-translucent greengreyish or tan spots, of the same width as the ribs, acting as shell windows; windows associated with well-defined interior convexities in the umbonal keel region.

Distribution and ecology - In Australia, F. mundum is known from QLD based on Shirley (1912) who reports 'Cardium munda Reeve' from Bundaberg (material not traced) and samples from Heron Island (MNHNIM-2014-5528, leg. J. Vidal, det. TP) and Lizard Island (UF 375687, leg. L. Kirkendale). The distribution of this species, which now includes northern WA (Figure 18D), encompasses the full IWP. Reeve's (1845) type locality, 'Lord Hood's Island, Pacific Ocean (found among coral sand)' is to be interpreted as Tuamotu Archipelago, South Marutea, $21^{\circ} 30^{\prime} \mathrm{S}, 135^{\circ} 33^{\prime} \mathrm{W}$ (Dance 1986: 112; Higo et al. 1999: 471), a south central Pacific penetration. Together with Hawaii in the northern Pacific (UF 296894) and other sites in the Western Pacific (e.g. Guam UF 288909, Tuvalu UF347854) this 
is a widespread distribution in the Pacific. However, the addition of recent records from S. Madagascar (MNHN, ATIMO VATAE Exped., det. TP), together with WA records, including Christmas Island (UF 337833), implies one of the largest ranges of all living Cardiidae. Fragum mundum is a shallow water species; available data suggest a partly epifaunal live habit, associated with corals and rocks, exposed, or to some extent nestling in crevices via a byssal attachment. It is a member of the photosymbiotic fragines and like C. cardissa, has transparent shell microstructural windows that facilitate light penetration through the shell (Persselin 1998; Kirkendale 2009).

\section{REMARKS}

The WA records are morphologically quite heterogeneous, with a different rib sculpture and a variable postero-ventral angle, possibly resulting from the epifaunal nestling lifestyle. Part of the type material (NHMUK 1978138, three syntypes, Figures 10I-J) is figured for comparison and specimens were chosen to highlight this heterogeneity. This observation, together with an enormous geographic range, indicates that this small species (H up to $12 \mathrm{~mm}$ ) may represent a species complex. Fragum mundum has been mistaken for juvenile Fragum fragum (Linnaeus, 1758) and this could in part explain the recent recognition of this species in WA (Willan et al. 2015).

\section{Fragum sp. aff. scruposum (Deshayes, 1855)}

Figures 10M-O

\section{Cardium scruposum Deshayes, 1855: 333.}

Hemicardium (Fragum) fragum var. carinata Lynge, 1909: 261, pl. 5 fig. 20 (not preoccupied by Cardium carinatum Bronn, 1831 nor Cardium carinatum Deshayes, 1838).

Corculum (Fragum) bannoi Otuka, 1937: 138-139, figs $54 \mathrm{a}-\mathrm{b}$.

Fragum bannoi Y. Otuka, 1937 - Huber 2010: 297, fig.

Fragum (Fragum) carinatum (Lynge, 1909) - Kendrick 1990: 37, fig. 2.

Not: Fragum scruposum (Deshayes, 1855) - ter Poorten 2009: pl. 7 figs 5-8, pl. 8 fig. 2; Huber 2010: 298, fig.; ter Poorten 2011: pl. 1097 figs 6-7 (=F. whitleyi).

\section{MATERIAL EXAMINED}

Australia: Western Australia: Houtman Abrolhos Islands, W. Wallaby Island, W. Beach. Leg. E.P. Hodgkin, 06.02.1964 (WAM S78123, 1 s.v.).

\section{DESCRIPTION}

Shell small (H 10-19 mm), inequilateral, solid, moderately inflated, subquadrate, with pronounced medio-posterior angulation, a postero-ventral angle of approximately $75-80^{\circ}$ and with a rounded anterior margin. Antero-ventral margins crenulate, posterior margin deeply serrate. Between 20-23 strong lowrounded radial ribs (of which $8-10$ on posterior slope), posteriorly smaller and more pointed triangular, umbonal keel prominent, formed by 1-2 strongly thickened ribs. Anterior and median ribs regularly covered with tubercles or coarse scales, finely tubercular posteriorly; interstices rather broad. Exterior and interior white.

\section{DISTRIBUTION AND ECOLOGY}

Fragum scruposum is currently known from Thailand, Malaysia, China, Taiwan, Indonesia, Solomon Islands, New Caledonia, Vanuatu and Fiji (colln MNHN, NTM, TP, J. Hylleberg, det. TP), hence the record from WA suggests a biogeographic affinity with the IWP.

\section{REMARKS}

The record of F. scruposum in WA is uncertain, firstly, because of the doubtful Recent nature of the sample and secondly, because the taxonomy of this, and related species, is complicated. WAM S78123 (Figures 10M-N) is a worn left valve with 22 ribs, including one thickened rib that could not be identified to species level with certainty; the height $(19.2 \mathrm{~mm})$ is greater than usual for F. scruposum. Its origin (Houtman Abrolhos Islands) may reflect a tropical penetration, as these islands are located in the path of the warm southerly flowing Leeuwin Current. Given the worn state, it cannot be unequivocally considered Recent and its presence in the modern Australian fauna needs to be confirmed by additional finds. Kendrick (1990, as Fragum (Fragum) carinatum) reports very similar material from Late Pleistocene deposits of Shark Bay and McNamara and Kendrick (1994) discuss additional finds from the Late Pleistocene of Barrow Island. Their material (WAM 87.594, Figure 10O) is in agreement with F. scruposum. Its presence in the Middle and Late Pleistocene assemblages is well established and it has been reported from the younger Quaternary of the Carnarvon and Perth Basins (McNamara and Kendrick 1994).

The three syntypes of the present species (NHMUK 1974140, Hylleberg 2004: 907, unnumbered figs; ter Poorten 2015: fig. 8a-b) have 1-2 pronounced ribs in both valves, coinciding with a strong carina running from the umbo to the postero-ventral corner. The total rib number is 21, 22 and 23 (counted on l.v.). The same rib structure and number counts for the type figure of Hemicardium (Fragum) fragum var. carinata Lynge, 1909 (pl. 5 fig. 20) and for Otuka's (1937: figs 54a-b) type figures of Corculum (Fragum) bannoi (Otuka, 1937). Examination of various samples of F. scruposum makes clear that the carina of a given specimen is predominantly composed of one thickened rib on the 


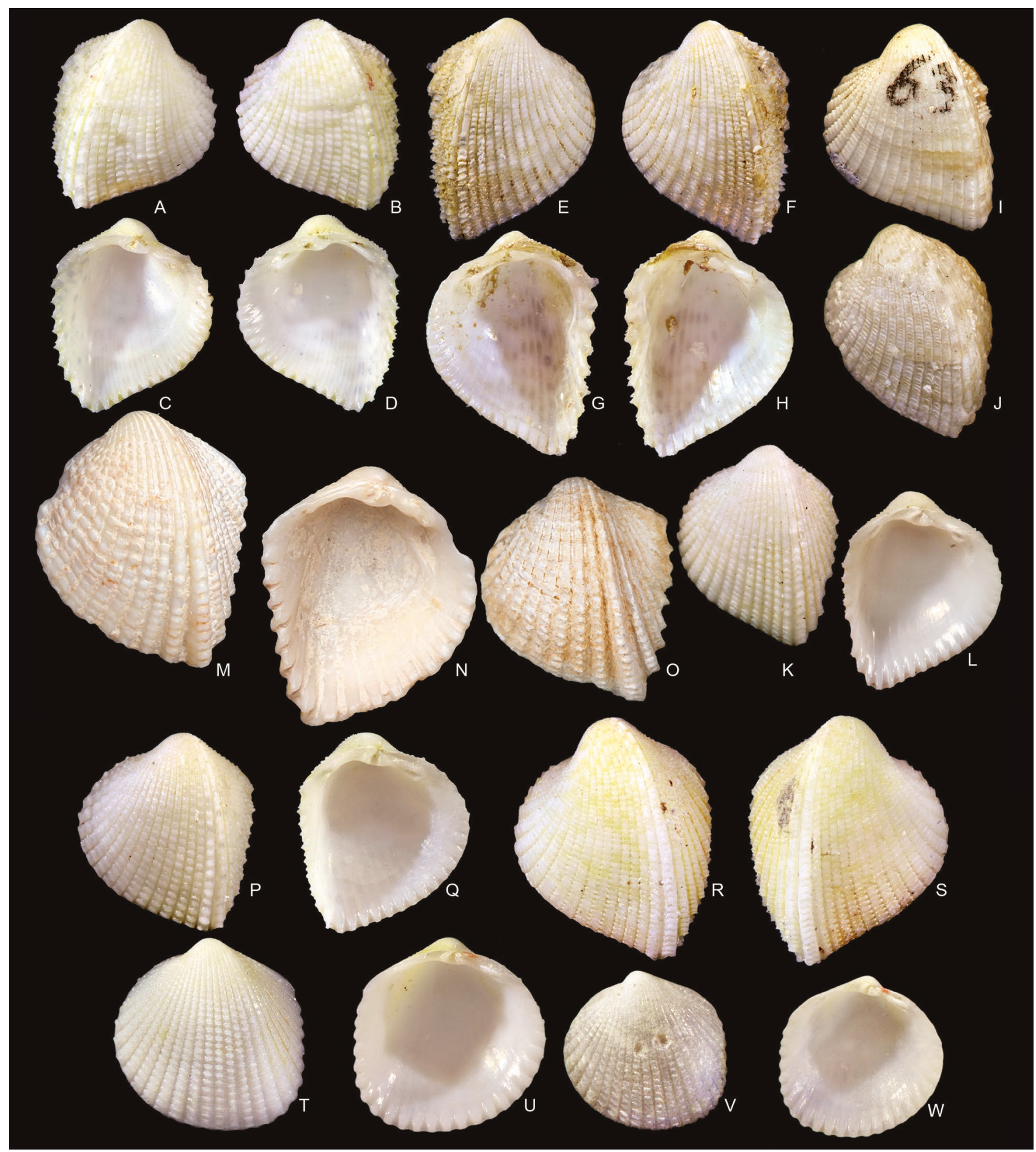

FIGURE 10

A, B, C, D, E, F, G, H, I, J, K, L, Fragum mundum (Reeve, 1845). A-D, Ashmore Reef, WA: WAM S75212, height $7.6 \mathrm{~mm}$. A, exterior of r.v., B, exterior of I.v., C, interior of I.v., D, interior of r.v.; E-H, Dampier Arch., WA: WAM S79509, height $9.3 \mathrm{~mm}$. E, exterior of r.V., F, exterior of I.V., G, interior of r.V., H, interior of I.v.; I-J, Lord Hood's Island: NHMUK 1978138, syntypes. I, height 8.8 mm, exterior of I.v., marked '63', J, height $8.8 \mathrm{~mm}$, exterior of I.V.; K-L, Cartier Reef, WA: NTM P.54210, height $8.3 \mathrm{~mm}$. K, exterior of I.V., $L$, interior of I.V.

M, N, O, Fragum sp. aff. scruposum (Deshayes, 1855). M-N, Houtman Abrolhos Islands, WA: WAM S78123, height $19.2 \mathrm{~mm}$. M, exterior of I.v., N, interior of I.v.; O, Shark Bay, WA (Pleistocene): WAM 87.594, height $13.2 \mathrm{~mm}$, exterior of I.v.;

P, Q, R, S, Fragum whitleyi Iredale, 1929; P-Q, Ashmore Reef, WA: WAM S91688, height 6.2 mm. P, exterior of I.v., Q, interior of I.v.; R-S, Ashmore Reef, WA: WAM S91571, height $10.5 \mathrm{~mm}$. R, exterior of I.V., S, exterior of r.v.

T, U, V, W, Fragum sueziense (Issel, 1869). Montebello Islands, WA: WAM S78323. T-U, length 5.9 mm, T, exterior of I.V., $U$, interior of I.V., $V-W$, length $5.1 \mathrm{~mm}, \mathrm{~V}$, exterior of I.V., $W$, interior of I.V. 
left valve, marginally interlocking with two thickened ribs on the right valve (e.g. TP 4064). Because of the similar shell morphology, Hemicardium (Fragum) fragum carinata Lynge, 1909 and Corculum (Fragum) bannoi (Otuka, 1937) are considered junior synonyms of Fragum scruposum. Taxonomic revision of the genus and molecular analysis is needed for a full systematic resolution that is outside the scope of this paper. FischerPiette (1977) considered Hemicardium (Fragum) fragum carinata Lynge, 1909 a junior homonym of Cardium carinatum Bronn, 1831: this opinion cannot hold as both taxa are not originally nor subsequently combined with the same generic name (ICZN 1999: Art. 53.3).

\section{Fragum sueziense (Issel, 1869)}

Figures $10 \mathrm{~T}-\mathrm{W}, 18 \mathrm{E}$

Cardium sueziensis Issel, 1869: 76, 252, pl. 3 fig. 4

? Cardium (Acanthocardia) omanense Melvill in Melvill \& Standen, 1907: 838-839, pl. 53 fig. 5

Cardium transclathratum Viader, 1951: 143, pl. 3 fig. 7.

Fragum sueziense (Issel, 1869) - ter Poorten 2009: pl. 7 figs 9-11, pl. 8 fig. 4; Huber 2010: 298, fig.; ter Poorten 2011: pl. 1097 figs 4-5.

\section{MATERIAL EXAMINED}

Australia: Western Australia: Canning, N. of Broome, $17^{\circ} 58^{\prime} \mathrm{S}, 122^{\circ} 14^{\prime} \mathrm{E}, 56 \mathrm{~m}, 21.12 .1969$. Leg. K. Ozawa, Tokyo University of Fisheries Exped. FV 'Umataka Maru' 1969, Stn UMD6925 (WAM S57164, 1 s.v.); Oceanic Shoals, Clerke Reef, $17^{\circ} 17^{\prime} 51.826^{\prime \prime S}$, 119²1'32.899"E, 15 m, 04.10.2014. Leg. C. Bryce, Woodside Kimberley Survey 2014, Stn 155/K14 (WAM S68163, 1 p.v., A); Pilbara Nearshore/Offshore, off Port Hedland, 20¹9'S, $118^{\circ} 37^{\prime}$ E, 09.10.1982. Leg. L.M. Marsh \& M. Bezant, CSIRO FRV 'Soela' Cruise V 1982, Stn (WAM S78308, 1 s.v.); Dampier Archipelago, Cape Lambert, 20³5'33.0"S, 117¹1'01.0"E, 02.1981. Leg. T. Meagher et al. (WAM S84245, 1 p.v., A); $20^{\circ} 23^{\prime} \mathrm{S}$, $116^{\circ} 52^{\prime} \mathrm{E}$ (WAM S78321, 1 s.v.); near the southern shore of Boat Passage, 20³1.4'S, 116 ${ }^{\circ} 49.9^{\prime} \mathrm{E}, 08.1978$. Leg. S.M. Slack-Smith, Stn ML11/6 (WAM S78309, 2 s.v.); inside Withnell Bay, 20³4'43.0"S, 116²7'14.0"E, 12.1980. Leg. T. Meagher et al. (WAM S84497, 3 p.v., A); Rosemary Island, $20^{\circ} 29^{\prime} \mathrm{S}, 116^{\circ} 36^{\prime} \mathrm{E}$, beach strand line, 21.05.1972. Leg. B.R. Wilson, Crown of Thorns Survey I May 1972 (WAM S78302, 1 s.v.); Montebello Islands, S. of Gannet Islands, to E. of Delta Island, 20²7'00"S, 115³3'59"E, 4-6 m, 14.08.1993. Leg. S.M. Slack-Smith, WAM Montebellos Islands Survey 1993, Stn MB12 (WAM S78293, 1 s.v.); E. side of Hermite Island, $20^{\circ} 28^{\prime} 35^{\prime \prime} \mathrm{S}, 115^{\circ} 33^{\prime} 03^{\prime \prime} \mathrm{E}, 4 \mathrm{~m}$, coarse sand, 24.08.1993. Leg. S.M. Slack-Smith, WAM Montebellos Islands Survey 1993, Stn MB36a (WAM S78323, 2 s.v.); Bunsen Channel, N. end of Trimouille Island, $20^{\circ} 23^{\prime} 08^{\prime \prime S}, 115^{\circ} 32^{\prime} 43^{\prime \prime E}, 3$ m, 21.08.1993. Leg. C. Bryce \& S.M. Slack-Smith, WAM Montebellos Islands Survey 1993, Stn MB28a (WAM S78109, 1 s.v.); E. side of Hermite Island, sandy beach, rock platform below oyster cliffs, 20²8'29"S, 115³2'43"E, 24.08.1993. Leg. L.M. Marsh, WAM Montebellos Islands Survey 1993, Stn MB36b (WAM S78310, 1 s.v.); Stephenson Channel near S. end of Hermite Island, $20^{\circ} 28^{\prime} 21^{\prime \prime S}, 115^{\circ} 32^{\prime} 27^{\prime \prime E}, 4 \mathrm{~m}$, 15.08.1993. Leg. S.M. Slack-Smith, WAM Montebellos Islands Survey 1993, Stn MB15a (WAM S78305, 1 s.v.; WAM S78306, 2 s.v.); sandbank connecting Hermite \& Buttercup Islands, intertidal sandflats, $20^{\circ} 29^{\prime}$ S, $115^{\circ} 32^{\prime}$ E, 15.08.1993. Leg. S.M. Slack-Smith, WAM Montebellos Islands Survey 1993, Stn MB14c (WAM S78318, 2 s.v.); Hermite Island, Sherry Lagoon, $20^{\circ} 29^{\prime} 20^{\prime \prime} \mathrm{S}, 115^{\circ} 31^{\prime} 50^{\prime \prime} \mathrm{E}$, intertidal embayment, muddy sand \& deeper channel, I/s cliffs, 16.08.1993. Leg. S.M. Slack-Smith, WAM Montebellos Islands Survey 1993, Stn MB14e (WAM S78328, 1 s.v.); sand bank near anchorage of CALM base, Hermite Island, $20^{\circ} 29^{\prime} 02^{\prime \prime} \mathrm{S}$, $115^{\circ} 31^{\prime} 46^{\prime \prime} \mathrm{E}$, intertidal sandbank, 14.08.1993. Leg. S.M. Slack-Smith, WAM Montebellos Islands Survey 1993, Stn MB14a (WAM S78249, 1 s.v.); Exmouth Gulf, 14 $\mathrm{km}$ E. of Muiron Island, Hawksbill Exploration Field, $21^{\circ} 41^{\prime} \mathrm{S}, 114^{\circ} 31^{\prime} \mathrm{E}, 15 \mathrm{~m}, 17.01 .1994$. Apache Energy Exmouth Gulf Survey 1993-94 (WAM S15923, 1 s.v.); N. end of Mydas Oil Rig, 214ㄷ'S, $114^{\circ} 23^{\prime} \mathrm{E}, 11.11 .1993$. Leg. Hadson Energy (WAM S78291, 1 s.v.); Midas Exploration Field, $4 \mathrm{~km} \mathrm{~S}$. of Muiron Islands, $21^{\circ} 45^{\prime} \mathrm{S}$, 114²2'E, 15 m, 20.11.1993. Leg. Apache Energy (WAM S84481, 1 p.v., A, 2 s.v.); North West Cape, Bay of Rest, $22^{\circ} 19^{\prime} \mathrm{S}, 114^{\circ} 08^{\prime} \mathrm{E}, 09.1987$. Leg. F.E. Wells \& C.W. Bryce (WAM S84248, 1 p.v., A); Ningaloo, Ningaloo Reef, off N. point of Mangrove Bay, transect 6, $22^{\circ} 17^{\prime} \mathrm{S}, 113^{\circ} 48^{\prime} \mathrm{E}, 1980$. Leg. T.D. Meagher \& Assoc. (WAM S78163, 1 p.v.); N. of Pt. Cloates, N. end of Bay, $22^{\circ} 37^{\prime} \mathrm{S}, 113^{\circ} 38.5^{\prime} \mathrm{E}$, bottom of sand, sponge \& dead shells, 30.08.1968. WAM Ningaloo Exped. 1968 (WAM S84251, 2 p.v., A); Maud's Landing, N. of Carnarvon, $23^{\circ} 07^{\prime} \mathrm{S}, 113^{\circ} 46^{\prime} \mathrm{E}, 07.1971$. Leg. D. \& B. Parker (WAM S78313, 1 s.v.); Coral Bay, $23^{\circ} 09^{\prime} \mathrm{S}, 113^{\circ} 46^{\prime} \mathrm{E}$, beach collection, 04.06.1981. Leg. C. Bryce \& S.M. SlackSmith (WAM S78340, 1 s.v.); Houtman Abrolhos Islands, Easter Group, N.E. of Rat Island, E. of Shag Rock, 28²' S, 11346.5'E, grab, 23.08.1977. Leg. C.W. Bryce \& L. Baxter, FRV 'Flinders' Dredging Cruise 1977, Stn G9 (WAM S84480, 1 p.v., A).

\section{DESCRIPTION}

Shell very small (H 5-10 $\mathrm{mm}$ ), rather solid, moderately inflated, subquadrate or rounded, generally slightly inequilateral with posterior margin somewhat straightened, but at times equilateral. Margins crenulate. Umbonal keel barely developed. Between 22-28 rather low and broad square radial ribs, topped with tubercles or slightly curved scales, sometimes partly commarginally aligned. Interstices often with concentric striae, varying from close set to quite widely spaced. Antero-dorsal margin not touching umbo, with most antero-dorsal part of the shell depressed beside umbo. 
Coloration completely white to cream occasionally with brown-pink spots or 2 purple-brown rays, visible inside and outside, or rarely completely lemon yellow.

\section{DISTRIBUTION AND ECOLOGY}

The present samples appear to represent the first Australian published records. In WA it has been recorded from shallow water (depth range 3-15 metres, one additional 56 metres record probably due to downslope transportation), mostly from onshore environments and one oceanic record (Figure 18E). Published data from QLD are lacking, however, several samples from Lizard Island are known: NTM P.54217 (leg. R.C. Willan, 07.10.1982, det. TP), UF 375842, UF 380191 (both leg. L. Kirkendale, 18.07.2003) and MNHN-IM-2014-5526 (leg. J. Vidal, 17.10.1994, det. TP), the latter consisting of no less than 40 valves. It has a wide IWP distribution.

\section{REMARKS}

Although this small-bodied species has likely been overlooked in many surveys that focus on macromolluscs, it not only proved to be one of the dominant bivalve taxa in the quantitative bulk samples of the northern bay of Safaga, Red Sea (Zuschin and Oliver 2003), but was also the most abundant cardiid species of the Philippine Panglao Marine Biology Project (both in terms of numbers of specimens and samples) (ter Poorten 2009). It is photosymbiotic and and can often be found in quite deep water compared to other photosymbiotic cardiids (e.g. 32-36 m live collected in Atoll Surprise, N. New Caledonia, MNHN, Stn DW1381; ter Poorten 2015: table 1) and is often found beached in shell grit. A few additional southerly WA samples are excluded as the locality is either questionable or the material does not have a recent appearance.

\section{Fragum whitleyi Iredale, 1929}

Figures 10P-S, 18F

Fragum whitleyi Iredale, 1929: 264, pl. 30 fig. 14.

Fragum (Fragum) scruposum (Deshayes, 1855) Lamprell and Whitehead 1992: pl. 31 fig. 206.

Fragum scruposum (Deshayes, 1855) - ter Poorten 2009: pl. 7 figs 5-8, pl. 8 fig. 2; Huber 2010: 298, fig.; ter Poorten 2011: pl. 1097 figs 6-7.

\section{MATERIAL EXAMINED}

Australia: Northern Territory: Pellew, W. coast of Gulf of Carpentaria, Borroloola, $1 \mathrm{~km}$ downstream from mouth of Bing Bong Creek, $15^{\circ} 48^{\prime} \mathrm{S}, 136^{\circ} 37^{\prime} \mathrm{E}$, 2-3 m, 06.09.1992. Leg. R.C. Willan (NTM P.1936, 1 p.v., A); Groote, N.W. coast of Gulf of Carpentaria, beach immediately adjacent to Port Bradshaw, $12^{\circ} 32.75^{\prime} \mathrm{S}, 136^{\circ} 44.35^{\prime} \mathrm{E}$, 06.07.1994. Leg. K. Colgan
(NTM P.4357, 2 s.v.); Arnhem Wessel, N.W. coast of Gulf of Carpentaria, Melville Bay, western side of Gove Peninsula, $12^{\circ} 15^{\prime} \mathrm{S}, 136^{\circ} 43^{\prime} \mathrm{E}, 12-17 \mathrm{~m}$, 07.1991. Leg. J.R. Hanley \& party (NTM P.37511, several s.v.).

Australia: Western Australia: Oceanic Shoals, Ashmore Reef, Lower E. side, $12^{\circ} 16^{\prime} 38.389^{\prime \prime S}$, $123^{\circ} 08^{\prime} 09.935^{\prime \prime E}, 1$ m, 28.09.2013. Leg. L. Kirkendale \& C. Bryce, Woodside Kimberley Survey 2013, Stn 129/K13 (WAM S91688, 1 s.v.); East Island, 12¹6'S, $123^{\circ} 06^{\prime} \mathrm{E}$, beach collection, 02.10.1977. Leg. J. Griffith, WAM Ashmore Reef and Cartier Island Survey 1997 (WAM S57144, 6 s.v.; WAM S84271, 1 s.v.); S. end, $12^{\circ} 15^{\prime} 44.388^{\prime \prime S}, 122^{\circ} 59^{\prime} 05.425^{\prime \prime E}, 1 \mathrm{~m}, 02.10 .2013$. Leg. L. Kirkendale \& C. Bryce, Woodside Kimberley Survey 2013, Stn 137/K13 (WAM S91571, 1 p.v., A); Pilbara Nearshore, Dampier Archipelago, Rosemary Island, Norbil Bay, $20^{\circ} 29^{\prime} \mathrm{S}, 116^{\circ} 35^{\prime} \mathrm{E}, 1-2 \mathrm{~m}$, dredge, 21.05.1972. Leg. B.R. Wilson, Crown of Thorns Survey 1 (WAM S13359, > 20 p.v., A); Houtman Abrolhos Islands, Easter Group, N.E. of Rat Island, 2842'S, 11346'5"E, grab, 23.07.1977. Leg. C. Bryce \& L. Baxter, FRV 'Flinders' Dredging Cruise, Stn G12 (WAM S13366, 1 p.v., A).

\section{DESCRIPTION}

Shell small (H 10-17 mm), solid, inequilateral, moderately inflated, subquadrate, a postero-ventral angle of approximately $80-90^{\circ}$ and with a rounded anterior margin. Antero-ventral margins crenulate, posterior margin serrate. Posterior slope set off from the rest of the shell by a clear radial angulation. Between 25-29 squarish to low-rounded radial ribs, posteriorly smaller, umbonal keel formed by 1-2 ribs that can be slightly thickened. Anterior ribs regularly covered with tubercles, median ribs with coarse, close-set scales, posterior ribs finely tubercular. Interstices rather broad and finely striate. Exterior white, occasionally lemon yellow or pinkish; interior white, rarely with a yellowish umbonal cavity.

\section{DISTRIBUTION AND ECOLOGY}

This species is described from QLD, Michaelmas Cay (Great Barrier Reef). In WA and NT it is known from several onshore and offshore records with the Houtman Abrolhos Islands as the southernmost record (Figure $18 \mathrm{~F})$. It has a wide distribution in the IWP, living in shallow waters.

\section{REMARKS}

Part of the studied material is tentatively assigned to the present species, with a shell morphology and rib number that correspond to Fragum whitleyi rather than to F. scruposum. On the other hand, the ribbing pattern is rather heterogenous (Figures 10P-S) and the species boundaries are not resolved. Like other small to medium sized Fragum species, the species is in need of a full taxonomic revision. 


\section{Genus Microfragum Habe, 1951}

Microfragum Habe, 1951: 148. Type species by original designation: Cardium festivum Deshayes, 1855; Recent, 'New Ireland' (Bismarck archipelago, Papua New Guinea).

\section{Microfragum festivum (Deshayes, 1855)}

Figures 9E-L, 18G

Cardium parvum G.B. Sowerby II, 1839: fig. 33; 1840b: 6, sp. 80; 1841: 110 (non Da Costa, 1778; nec Philippi, 1844).

Cardium festivum Deshayes, 1855: 332.

Ctenocardia (Microfragum) festiva (G.P. Deshayes, 1855) - Huber 2010: 300, fig.

Microfragum festivum (Deshayes, 1855) - Lamprell and Whitehead 1992: pl. 32 fig. 213; ter Poorten 2009: pl. 9 figs 6-7; ter Poorten 2011: pl. 1104 figs 2-4.

\section{MATERIAL EXAMINED}

Australia: Western Australia: Oceanic Shoals, Ashmore Reef, approx. mid-northern coast, $12^{\circ} 13.47^{\prime} \mathrm{S}$, $122^{\circ} 57.77^{\prime} \mathrm{E}$, on the surface of silty sand, at the base of outer reef slope, 22 m, 10.09.1996. Leg. R.C. Willan (NTM P.24387, 1 s.v.); Rowley Shoals, Clerke Reef, $17^{\circ} 16^{\prime} 26^{\prime \prime S}, 119^{\circ} 21^{\prime} 34^{\prime \prime E}$, intertidal sand flat, $0 \mathrm{~m}$, 22.07.1982. Leg. WA Museum Party, WAM Rowley Shoals Exped. 1982, Stn 16 (WAM S40376, 1 p.v., A); $17^{\circ} 20^{\prime} \mathrm{S}, 119^{\circ} 20^{\prime} \mathrm{E}$, coral clean sand substrate, 0-1 m, 21.08.1983. Leg. B.C. Russell (NTM, P.40065, 1 s.v.).

Literature records: Willan (2005: 79): Ashmore Reef; Wilson (2013: 353): Oceanic Shoals.

\section{DESCRIPTION}

Shell small to medium (L 10-15 mm), solid, subequilateral, rounded quadrate, longer than high and with a rather weak medio-posterior radial angulation. Margins rounded, posterior margin slightly truncated. Between 33-45 radial ribs. Ribs flattened, rounded and densely covered with arched, thin imbricated lamellae that easily wear off, even in fresh material. The lamellae are of a homogeneous size and strength. Interstices narrow and finely punctuated. Exterior colour whitish to cream with brown-pinkish splashes; interior variable, ranging from white to orange in umbonal cavity or with brownish rays.

\section{DISTRIBUTION AND ECOLOGY}

All WA records are found intertidally or in shallow water off the oceanic northern offshore reefs (Figure 18G; see also Wilson 2013: table 8.8). It is a widespread tropical Central IWP species, also known from QLD (Lamprell and Whitehead 1992; live collected by the second author at Lizard Island, UF 374119) and East
Timor (ZMA, Siboga Exped., Stn 282, 1 p.v., det. TP). It predominantly occurs in lagoons and other non-exposed shallow water environments, occupying soft bottoms and coral sand (ter Poorten 2009).

\section{REMARKS}

Two of the syntypes are figured for comparison (NHMUK 1974134, Figures 9I-L). The scales easily wear off, rendering specific separation with the partly sympatric M. subfestivum (Vidal \& Kirkendale, 2007) sometimes problematic, although the latter has broader interstices. WA samples of this latter species were not present in the WAM and NTM collections, but this species is also likely to occur in northern Australia given its occurrence in South Indonesia.

\section{Subfamily Cardiinae Lamarck, 1809}

\section{REMARKS}

Following the molecular phylogenetic study of Herrera et al. (2015), Fulvia and 'Laevicardium' lobulatum are placed in Cardiinae. Clade 6 of this study includes three subclades, the first containing ' $L$.' lobulatum; the second Europicardium, Cardium and Bucardium and the third Fulvia. Following ter Poorten and Hylleberg (2017), Laevifulvia is synonymised with Fulvia.

\section{Genus Fulvia J.E. Gray, 1853}

Fulvia J.E. Gray, 1853: 40. Type species by monotypy: Cardium apertum Bruguière, 1789; Recent, 'l'océan Asiatique' \& 'Jamaïque' (Indo-West Pacific; Jamaica in the original publication was in error).

Laevifulvia Vidal, 1994: 97 (as a subgenus of Fulvia). Type species by original designation: Cardium hungerfordi undatopictum Pilsbry, 1904; Recent, 'Hirado, Hizen' [Kyūshū, Nagasaki Pref.], Japan.

\section{Fulvia australis (G.B. Sowerby II, 1834)}

Figures 11A-D, 19C

Cardium striatum Spengler, 1799: 45 [never used].

Cardium australe G.B. Sowerby II, 1834: figs 12, 12*.

Cardium varium G.B. Sowerby II, 1834: fig. 19.

Cardium pulchrum Reeve, 1845: sp. 98, pl. 19 fig. 98.

Fulvia australe (Sowerby, 1834) - Lamprell and Whitehead 1992: pl. 34 fig. 227.

Fulvia (Fulvia) australis (G.B. Sowerby II, 1834) - ter Poorten 2009: pl. 12 figs 6-10; Huber 2010: 304, fig. (pars); ter Poorten 2011: pl. 1108 figs 1-2. 


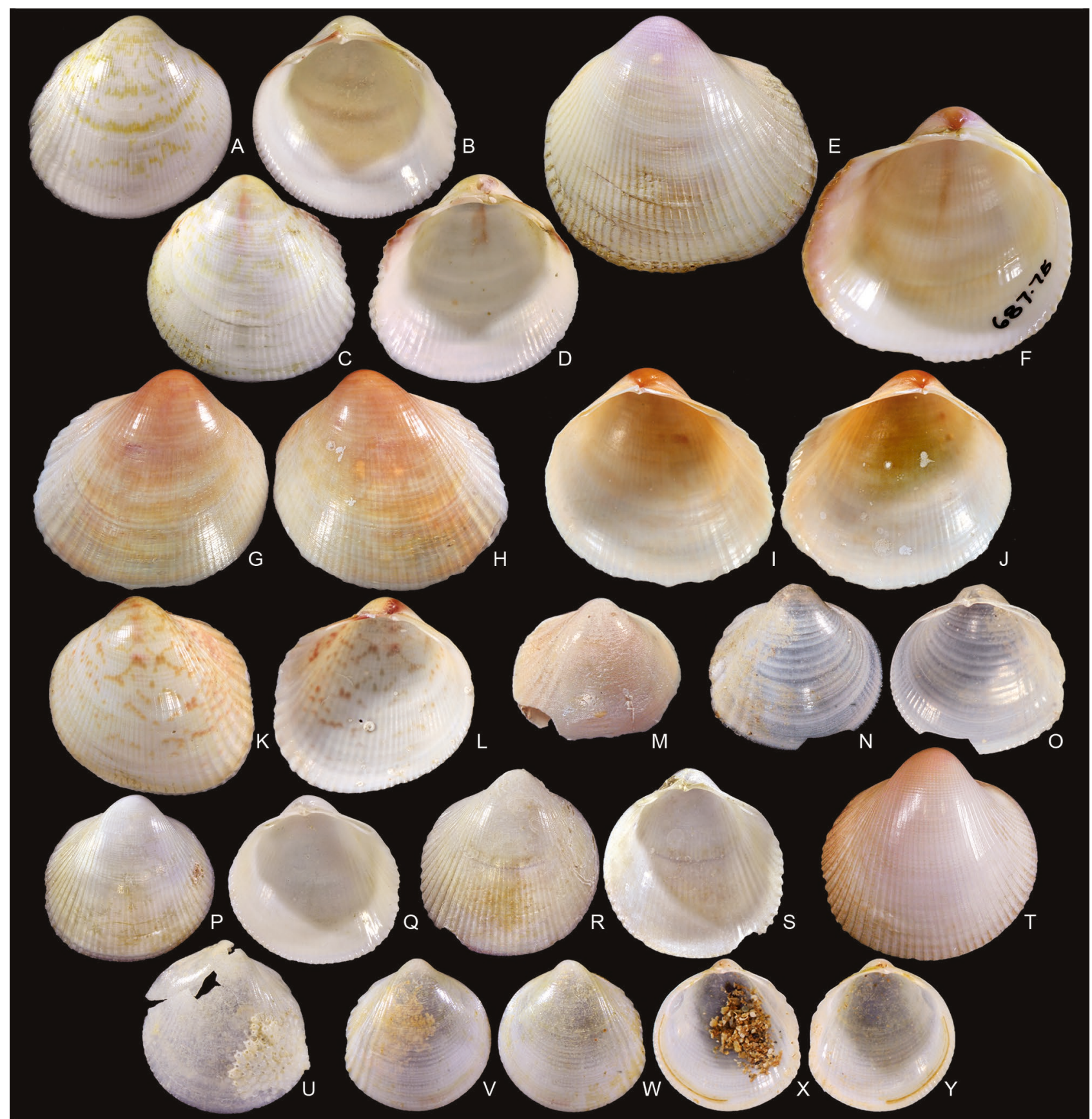

FIGURE 11 A, B, C, D, Fulvia australis (G.B. Sowerby II, 1834). A-B, Seringapatam Reef, WA: WAM S39958, length 22.6 $\mathrm{mm}$. A, exterior of r.v., B, interior of r.v.; C-D, De Freycinet Island, WA: WAM S66931, length $24.1 \mathrm{~mm}$. C, exterior of I.V., D, interior of I.V.

E, F, Fulvia laevigata (Linnaeus, 1758). Coronation Island, WA: WAM S56804, length $31.5 \mathrm{~mm}$. E, exterior of I.V., F, interior of I.v.

G, H, I, J, Fulvia boholensis Vidal, 1994. Dampier Arch., WA: NTM P.54198, length 24.2 mm. G, exterior of r.v., H, exterior of I.V., I, interior of r.v., J, interior of I.v.

K, L, Fulvia fragiformis Vidal, 1994. Great Barrier Reef, QLD: NTM P.19858, length $17.0 \mathrm{~mm}$. K, exterior of I.V., L, interior of I.v.

M, N, O, Fulvia hungerfordi (G.B. Sowerby III, 1901). M, N. of Newcastle, NSW: NTM P.36678. length 4.7 mm (defect), exterior of r.v.; N-O, Darwin, NT: NTM P.7260, length $5.0 \mathrm{~mm}$ (defect). N, exterior of r.V., $\mathrm{O}$, interior of r.v.

P, Q, R, S, T, Fulvia scalata Vidal, 1994. P-S, off Mermaid Reef, WA: WAM S34673. P-Q, height 14.7 mm, P, exterior of r.v., Q, interior of r.v., R-S, height $16.4 \mathrm{~mm}$, R, exterior of r.v., S, interior of r.v.; T, Tiwaka River mouth, New Caledonia: MNHN-IM-2000-4021, holotype, length $19.3 \mathrm{~mm}$, exterior of r.V.

U, V, W, X, Y, Fulvia undatopicta (Pilsbry, 1904). U, N. of Port Walcott, WA: WAM S78297, height c. 6.5 mm (broken), exterior of I.V.; V-Y, E. of Muiron Islands, WA: WAM S78338, height $4.8 \mathrm{~mm}$. V, exterior of r.V., W, exterior of I.V., $X$, interior of r.V., Y, interior of I.V. 


\section{MATERIAL EXAMINED}

Australia: Northern Territory: Cobourg, Port Essington, 5 nautical miles N.W. of Smith Point, western end of Orontes Reef, $11^{\circ} 4^{\prime} \mathrm{S}, 132^{\circ} 3^{\prime} \mathrm{E}, 17 \mathrm{~m}, 09.08 .1986$. Leg. R.C. Willan (NTM P.54200, 1 p.v.).

Australia: Western Australia: Kimberley, Malcolm Island, $14^{\circ} 31^{\prime}$ S, $125^{\circ} 54^{\prime} \mathrm{E}, 31.10 .1976$. Leg. S.M. SlackSmith, WAM Admiralty Gulf Mangal Survey 1976 (WAM S66929, 2 p.v., 1 s.v.); De Freycinet Island, 1459.03'S, 12432.03'E, diving, $32 \mathrm{~m}, 01.12 .1996$. Leg. C. Bryce, WAM Central Kimberley Coast Survey 1996 (WAM S66931, 1 s.v.); Canning, Packer Island, $16.56675^{\circ} \mathrm{S}, 122.72845^{\circ} \mathrm{E}$, benthic dredge, $15.8-16.6$ $\mathrm{m}, 25.06 .2008$. Leg. J. Keesing, CSIRO Survey June 2008, Stn 487 (WAM S44417, 2 p.v., A); Oceanic Shoals, Seringapatam Reef, Lagoon, $13^{\circ} 38^{\prime} \mathrm{S}, 122^{\circ} 05^{\prime} \mathrm{E}$, 16.09.1994. Leg. C. Bryce \& H. Morrison, Bryce \& Morrison Kimberley Survey 1994 (WAM S39958, 1 s.v.); Lagoon, $13^{\circ} 38^{\prime} \mathrm{S}, 122^{\circ} 05^{\prime} \mathrm{E}, 8 \mathrm{~m}, 16.09 .1996$. Leg. C. Bryce \& H. Morrison, WAM Offshore Kimberley Survey 1996 (WAM S39916, 1 s.v.); Scott Reef, S. end, $14^{\circ} 11^{\prime} 55^{\prime \prime S}, 121^{\circ} 47^{\prime} 35^{\prime \prime E}$, intertidal sand flat, 0 m, 15.09.1984. Leg. F. Wells \& C. Bryce, WAM Scott \& Seringapatam Reefs Survey 1984, Stn 19 (WAM S40377, 2 p.v., A); Pilbara Nearshore, Dampier Archipelago, Lady Nora Flats, N.E. side of Rosemary Island, 20²9'S, $116^{\circ} 36^{\prime} \mathrm{E}, 30.10 .1971$. Leg. B.R. Wilson (WAM S66930, 2 p.v., 1 s.v.); Rosemary Island, Norbill Bay, 20²9'S, 116 35'E, dredge, sand, 1-2 m, 21.05.1972. Crown of Thorns Survey 1 (WAM S82972, 4 p.v., A); Mermaid Passage, $20^{\circ} 42.42^{\prime} \mathrm{S}, 116^{\circ} 30.31^{\prime} \mathrm{E}$, comminuted rubble incorporating some silt, $10 \mathrm{~m}, 21.08 .1994$. Leg. R.C. Willan (NTM P.21678, 1 p.v., 1 s.v.); N. of N.W. point of Eaglehawk Island, 20³8.94'S, $116^{\circ} 26.22^{\prime} \mathrm{E}$, sponges, soft corals, gorgonians, $10 \mathrm{~m}, 03.09 .1999$. Leg. S.M. Slack-Smith et al., Woodside Dampier Exped. III 1999, Stn DA3/99/56 (WAM S22190, 1p.v., A); Zuytdorp, S. of Ningaloo Marine Park, $24^{\circ} 00.9114^{\prime}$ S, $113^{\circ} 26.4864^{\prime} \mathrm{E}$, epibenthic sled, 27.6-27.7 m, 03.02.2008. Leg. M.P. Salotti \& S.M. Slack-Smith, AIMS-WAM RV 'Solander', Stn RVS4545/2008/D080 (WAM S84236, 1 p.v., A).

Literature records: Willan (2005): Hibernia Reef; Wilson (2013: 353): Oceanic Shoals, Pilbara and Canning.

\section{DESCRIPTION}

Shell medium sized (H 25-35 mm), rather thin, slightly obliquely ovate, $\mathrm{H} / \mathrm{L}$ ratio highly variable, normally height approximately equals length. Between 34-55 radial ribs, well developed and irregular on posterior third of the shell and nearly smooth on median part. Periostracal insertions present on posterior part of the ribs. Minute, evenly disposed granulations often observed on anterior half of the shell. Lunular heart small, raised and elongate, equally sized in both valves.
Colour variable, often whitish blotched with pink, purple or brown. Interior white, yellowish, orange or purple; sometimes with a purple umbonal ray.

\section{DISTRIBUTION AND ECOLOGY}

This study and Willan et al. (2015) provides records from coastal and offshore areas of northern WA and coastal NT (Figure 19C). It is also known from QLD (WAM, RMNH, TP) and is a common and widespread IWP species. The species lives intertidally and in shallow waters (depth range life taken WA samples: 0-28 meters) on mud and sand, often in association with seagrass.

\section{REMARKS}

Due to a resemblance with other congeners and the paucity of diagnostic characters, it may well have been overlooked. A rather similar looking species, Fulvia nienkeae ter Poorten, 2012, is known from QLD, based on records in RMNH (ex ZMA), NTM and NHMUK (det. TP). It can be distinguished from $F$. australis by its slightly larger size (up to $44 \mathrm{~mm}$ ), higher rib number (54-68), more quadrangular-elongate shape $(\mathrm{H}>\mathrm{L})$, and large lunular area. Additionally, it lives in somewhat deeper water than $F$. australis. Another closely related but poorly known species, Fulvia fragiformis Vidal, 1994, is reported from Australia for the first time (Myrmidon Reef, QLD, NTM P.19858) and is figured for comparison (Figures $11 \mathrm{~K}-\mathrm{L}$ ). It has a characteristic, strongly inequilateral fragiform shape.

\section{Fulvia boholensis Vidal, 1994}

\section{Figures $11 \mathrm{G}-\mathrm{J}$}

Fulvia (Fulvia) boholensis Vidal, 1994: 107, pl. 3 figs 6a-b; ter Poorten 2009: pl. 13 figs 1-4; Huber 2010: 304, fig.; ter Poorten 2011: pl. 1107 figs 3-5.

\section{MATERIAL EXAMINED}

Australia: Western Australia: Pilbara Nearshore, Dampier Archipelago, Mermaid Passage, 2042.42'S, $116^{\circ} 30.31^{\prime} \mathrm{E}$, fine rubble incorporating some silt, $10 \mathrm{~m}$, 21.08.1994. Leg. R.C. Willan (NTM P.54198, 1 p.v.)

Literature records: Vidal (1994): Dampier (QM, 1).

\section{DESCRIPTION}

Shell medium sized (L 30-37 mm), rather thin, obliquely ovate, usually longer than high, quite often very slightly gaping posteriorly. Between 47-55 flattened but readily visible radial ribs, more pronounced on posterior third of the shell. Internal marginal ribbing relatively smooth. Periostracal insertions present on rib crests or posteriorly, developing into tiny calcified rugae on posterior slope. Anterior half of the shell densely granulated. Lunular heart very small. Exterior and 
interior generally bright orange, but not uncommonly whitish with cream triangles with extensive reddishbrown maculations, becoming darker towards the umbo. In the whitish shells with cream triangles, a patch of orange is still visible near the inner posterior margin and in rib interstices of the posterior slope.

\section{DISTRIBUTION AND ECOLOGY}

The known distribution of $F$. boholensis is from Thailand, Vietnam, Philippines through to Indonesia. It occurs in shallow water (ter Poorten 2009).

\section{REMARKS}

The WA record of Vidal (1994), a yellow-orange specimen with white margins, could not be traced in the QM (personal commumication John Healy, 05.2012). This record is confirmed by the presence of another Dampier sample in the NTM collection. The species can easily be confused with $F$. australis and $F$. aperta (Bruguière, 1789), certainly when the typical bright orange colour variation is not present.

\section{Fulvia hungerfordi (G.B. Sowerby III, 1901)}

Figures 11M-O, 19D

Cardium (Papyridia) [sic! err. pro Papyridea] hungerfordi G.B. Sowerby III, 1901: pl. 9 fig. 5.

Fulvia (Laevifulvia) prashadi Vidal, 1994: 111-112, pl. 3 figs $8 \mathrm{a}-\mathrm{b}$.

Fulvia (Laevifulvia) hungerfordi (G.B. Sowerby III, 1901) - ter Poorten 2009: pl. 14 figs 5-8, pl. 15 figs 3-4; Huber 2010: 305, fig.; ter Poorten 2011: pl. 1110 figs 4-6.

\section{MATERIAL EXAMINED}

Australia: Northern Territory: Groote, N.W. coast of Gulf of Carpentaria, western side of Gove Peninsula, Melville Bay, $12^{\circ} 11.75^{\prime} \mathrm{E}, 136^{\circ} 41.28^{\prime} \mathrm{E}, 12-17 \mathrm{~m}$, 19.03.1992. Leg. J.R. Hanley \& party (NTM P.9284, 3 s.v.); Arnhem Wessel, central Arnhem Land, S.E. of Milingimbi settlement, $12^{\circ} 9.273^{\prime} \mathrm{S}, 134^{\circ} 57.930^{\prime} \mathrm{E}$, 0.9 m, 05.12.2004. Leg. S.K. Horner, G.M. Dally \& party (NTM P.37056, 1 s.v.); Van Diemens Gulf, western Arnhem Land, Kakadu National Park, N. of Field Island, $12^{\circ} 3.55^{\prime} \mathrm{S}, 132^{\circ} 23.44^{\prime} \mathrm{E}, 3 \mathrm{~m}, 23.11 .2004$. Leg. N. Smit (NTM P.32069, 5 s.v.); Anson Beagle, N.N.E. of Darwin, Shoal Bay, Gun Point Public Beach, $12^{\circ} 19.55^{\prime} \mathrm{S}, 131^{\circ} 0.8^{\prime} \mathrm{E}, 26.10 .1997$. Leg. R.C. Willan, J.D. Taylor \& E.A. Glover (NTM P.10276, 3 s.v.); Darwin Harbour, Iron Ore Wharf, $12^{\circ} 28.22^{\prime} \mathrm{S}, 130^{\circ} 51.01^{\prime} \mathrm{E}, 6 \mathrm{~m}$, 16.08.1998. Leg. C.L. Hewitt \& party (NTM P.11700, 1 S.v.); E. side of Darwin Harbour, 1 nautical mile W. of Fannie Bay Beach, 'E' Buoy, 12²5.33'S, 13049.03'E, 07.07.1993. Leg. R.S. Williams (NTM P.7260, 1 s.v.).

\section{DESCRIPTION}

Shell small (L 10-15 mm), thin, inflated, generally inequilateral with posterior third expanded and posterior margin truncated. Radial ribs strongly developed on posterior third, anteriorly less accentuated, obsolete on median part, which has a glossy and smooth appearance. Dense granulations can be present, often limited to posterior quarter of the shell and near the ventral margin. Internal marginal crenulations usually weakly defined in the mid ventral margin edge, well developed towards anterior and posterior margin and visible over a long distance from the margins. Lunular heart small. Exterior and interior colour uniform whitish to reddish brown, adults sometimes with concentric growth lines visible as a change in shell colour and opacity.

Distribution and ecology - Not encountered in WA, but present in the continental coastal waters of NT (Figure 19D). Found in shallow water (depth range 0-17 metres, based on dead recordings). Two samples from Kurrimine Beach, QLD (WAM S78275, 4 s.v.) and central NSW (NTM P.36678, 1 p.v., Figure 11M) have also been located. To date, the species has not been reported from Australia. It is widely distributed in the Central IWP, has a marked tolerance for turbid and polluted waters (Shin 1985: Tolo Harbour, Hong Kong; Madang Harbour, Papua New Guinea, MNHN colln) and prefers sheltered, muddy habitats.

\section{REMARKS}

Fulvia hungerfordi has likely been overlooked due to its small size, fragile shell and superficial similarity with other congeners. It is also known from southern Indonesia, Sumba (ZMA, Siboga Exped., Stn 53, 4 s.v., det. TP). It is likely that other small Fulvia species occur in the northern half of Australia but as yet have not been recognised.

\section{Fulvia laevigata (Linnaeus, 1758)}

Figures 11E-F, 19E

Cardium laevigatum Linnaeus, 1758: 680.

Cardium papyracea, testa cordata, [...] Chemnitz, 1782: 190, pl. 18 fig. 184 (rejected work, Direction 1 ICZN).

Cardium papyraceum Schröter, 1788: 19 (non binominal).

Cardium papyraceum Bruguière, 1789: 231.

? Cardium pallidum Reeve, 1845: sp. 92, pl. 18 fig. 92.

Fulvia voskuili Healy \& Lamprell, 1992: 89-91, pl. 4 figs $\mathrm{a}-\mathrm{d}$. 
Fulvia sp. - Lamprell \& Whitehead 1992: pl. 34 fig. 226 [= holotype of Fulvia voskuili Healy \& Lamprell, 1992; jun. syn. of Cardium laevigatum Linnaeus].

Fulvia (Fulvia) papyracea (Bruguière, 1789) Lamprell and Healy 1998: 256.

Fulvia (Fulvia) laevigata (Linnaeus, 1758) - ter Poorten 2009: pl. 12 figs 1-5, pl. 15 fig. 1; Huber 2010: 304, fig.; ter Poorten 2011: pl. 1109 figs 3-5.

\section{MATERIAL EXAMINED}

Australia: Northern Territory: Groote, Groote Eylandt, pre 09.07 .1968 (WAM S78181, 3 p.v.); NW. coast of Gulf of Carpentaria, Gove Peninsula, near Nhulunbuy, Town Beach point, $12^{\circ} 11^{\prime} \mathrm{S}, 136^{\circ} 47^{\prime} \mathrm{E}$, 17.07.1996. Leg. F.W. McGreevy (NTM P.52681, 1 s.v.); S. end of Turtle Beach, 12 ${ }^{\circ} 11^{\prime} \mathrm{S}, 136^{\circ} 47^{\prime} \mathrm{E}, 21.07 .1996$. Leg. F.W. McGreevy (NTM P.41556, 1 s.v.); beach immediately adjacent to Port Bradshaw, $12^{\circ} 32.75^{\prime} \mathrm{S}$, 13644.35'E, 06.07.1994. Leg. K. Colgan (NTM P.4358, 1 p.v., 12 s.v.); W. side of Gove Peninsula, Melville Bay, $1^{\circ} 15^{\prime} \mathrm{S}, 136^{\circ} 43^{\prime} \mathrm{E}, 12-17 \mathrm{~m}, 07.1991$. Leg. J.R. Hanley \& party (NTM P.37537, 1 p.v., 2 s.v.); W. side of Gove Peninsula, N. coast of Melville Bay, sandy beach immediately S.E. of Alcan Aluminium Refinery, $12^{\circ} 11.347^{\prime} \mathrm{S}, 136^{\circ} 41.879^{\prime} \mathrm{E}, 04.09 .2007$. Leg. S.M. Gregg (NTM P.40663, 2 s.v.); Arnhem Wessel, eastern Arnhem Land, NW. coast of Elcho Island, 1148.277'S, 13553.062'E, 23.07.2008. Leg. A. Beatty \& J. Damaso (NTM P.41842, 3 s.v.); central western coast of Elcho Island, immediately N. of Galiwinku, Duduhpu (= First Creek), $11^{\circ} 59.951^{\prime} \mathrm{S}, 135^{\circ} 34.267^{\prime} \mathrm{E}, 08.06 .2011$. Leg. D.G. Freier (NTM P.50883, 1 s.v.); central Arnhem Land, Millingimbi, approx. $260 \mathrm{~m} \mathrm{~S}$. of Mjrungga Island, $11^{\circ} 57.345^{\prime} \mathrm{S}, 135^{\circ} 5.657^{\prime} \mathrm{E}, 5.2 \mathrm{~m}, 04.12 .2004$. Leg. S.K. Horner, G.M. Dally \& party (NTM P.30064, 1 p.v., A); Boucaut Bay, Yilan, 12¹.7'S, 134³8.200'E, 19.10.1994. Leg. C. Coleman (NTM P.6899, 2 s.v.); N. of Maningrida, mouth of Liverpool River, $12^{\circ} 1.165^{\prime} \mathrm{S}$, 134 $14.645^{\prime} \mathrm{E}, 2.7$ m, 02.12.2004. Leg. S.K. Horner, G.M. Dally \& party (NTM P.37155, 1 s.v.); Maningrida, $12^{\circ} 03^{\prime} \mathrm{S}, 134^{\circ} 13^{\prime} \mathrm{E}, 08.1993$. Leg. C. Coleman (NTM P.7146, 3 s.v.); Maningrida, $12^{\circ} 03^{\prime} \mathrm{S}, 134^{\circ} 13^{\prime} \mathrm{E}, 01.1980$. Leg. B. Ether (NTM P.7034, 5 s.v.); Cobourg, South Goulburn Island, approx. $2 \mathrm{~km}$ E. of McPherson Point, $1^{\circ} 38.730^{\prime} \mathrm{S}, 133^{\circ} 26.386 ' \mathrm{E}, 1 \mathrm{~m}, 29.11 .2004$. Leg. S.K. Horner, G.M. Dally \& party (NTM P.31275, 1 p.v., A); N.W. extremity of Arnhem Land, central eastern coast of Croker Island, Minjilang, $11^{\circ} 9.1020^{\prime} \mathrm{S}, 132^{\circ} 34.902^{\prime} \mathrm{E}$, 08.08.2008. Leg. H.K. Larson \& S. Hoeng (NTM P.41917, 1 s.v.); N. coast of Cobourg Peninsula, mideastern coast of Port Essington, N. side of Table Head, $11^{\circ} 14.5^{\prime} \mathrm{S}, 132^{\circ} 11^{\prime} \mathrm{E}, 14.09 .1998$. Leg. L.K. Gravener (NTM P.11350, 1 p.v., 4 s.v.); Port Essington, Record Point, $11^{\circ} 19^{\prime} \mathrm{S}, 132^{\circ} 10.3^{\prime} \mathrm{E}, 1969$. Leg. H. Blackburn (NTM P.5221, 1 p.v.); Port Essington, mouth of
Caiman Creek, $11^{\circ} 21^{\prime} \mathrm{S}, 132^{\circ} 06^{\prime} \mathrm{E}, 18.09 .1985$. Leg. P.N. Alderslade (NTM P.54158, 1 p.v.); S.W. section of Port Essington, margin of islet just N. of Minto Head, $11^{\circ} 11^{\prime} \mathrm{S}, 132^{\circ} 03.4^{\prime} \mathrm{E}, 12.08 .1986$. Leg. R.C. Willan (NTM P.1831, 2 s.v.); Port Essington, 5 nautical miles N.W. of Smith Point, western end of Orontes Reef, $11^{\circ} 04^{\prime} \mathrm{S}, 132^{\circ} 03^{\prime} \mathrm{E}, 17 \mathrm{~m}, 09.08 .1986$. Leg. R.C. Willan (NTM P.32020, 2 s.v.; NTM P.54201, 2 p.v., 1 s.v.); Port Essington, Coral Bay, off small Island at S. end of Bay, $11^{\circ} 11^{\prime} \mathrm{S}, 132^{\circ} 03^{\prime} \mathrm{E}, 0-8 \mathrm{~m}, 11.08 .1986$. Leg. S.M. SlackSmith, Stn CP\#96 (WAM S78180, 1 p.v.); Vashon Head, $11^{\circ} 08^{\prime} \mathrm{S}, 132^{\circ} 0^{\prime} \mathrm{E}, 1969$. Leg. H. Blackburn (NTM P.713, 2 p.v.); Van Diemens Gulf, Port Essington \& Cobourg Peninsula, $11^{\circ} 28^{\prime} 35.25^{\prime \prime S}, 132^{\circ} 18^{\prime} 31.97 " E$, 1969. Leg. H. Blackburn (WAM S78189, 4 p.v.); Anson Beagle, N. of Darwin, N. of Lee Point, $12^{\circ} 18.84^{\prime} \mathrm{S}, 130^{\circ} 52.866^{\prime} \mathrm{E}, 10$ m, 11.10.1993. Leg. A.Y. Williams (NTM P.4436, 1 s.v.); N. of Darwin, Lee Point, $12^{\circ} 19^{\prime} \mathrm{S}, 130^{\circ} 54^{\prime} \mathrm{E}, 16.08 .1992$. Leg. R.C. Willan (NTM P.14900, 1 s.v.); Lee Point, $12^{\circ} 19^{\prime}$ S, $130^{\circ} 54^{\prime}$ E, 29.09.1992. Leg. R.C. Willan, M.M. Burke \& A.E. Wells (NTM P.23167, 1 s.v.); Lee Point, $12^{\circ} 19^{\prime}$ S, $130^{\circ} 54^{\prime} \mathrm{E}, 28.02 .1993$. Leg. R.C. Willan \& A.W. Klishans (NTM P.41003, 1 s.v.); Lee Point, $12^{\circ} 19^{\prime}$ S, $130^{\circ} 54^{\prime} \mathrm{E}, 18.07 .2006$. Leg. R.C. Willan \& R. Burn (NTM P.38353, 1 s.v.); Lee Point, $12^{\circ} 19^{\prime} \mathrm{S}, 130^{\circ} 54^{\prime} \mathrm{E}$, sandy beach, 03.2005. Leg. M. Huber (TP 2278, 3 s.v.); Lee Point, $12^{\circ} 19^{\prime} \mathrm{S}, 130^{\circ} 54^{\prime} \mathrm{E}, 13.07 .2014$. Leg. J.J. ter Poorten \& R.C. Willan (TP 4464, 4 s.v.); Darwin, Shoal Bay, Tree Point, $12^{\circ} 19.55^{\prime} \mathrm{S}, 131^{\circ} 0.8^{\prime} \mathrm{E}, 10.11 .1984$ (TP 2131, 3 p.v.; NMR 20206, 1 p.v.); Tree Point, $12^{\circ} 19.55^{\prime} \mathrm{S}$, $131^{\circ} 0.8^{\prime} \mathrm{E}, 26.10 .1997$. Leg. R.C. Willan, J.D. Taylor \& E.A. Glover (NTM P.10733, 2 p.v.); western section of Gunn Point Beach, $12^{\circ} 14.8^{\prime} \mathrm{S}, 131^{\circ} 1.7^{\prime} \mathrm{E}, 30.12 .1992$. Leg. A.W. Klishans (NTM P.19526, 1 s.v.); mouth of Howard River, $12^{\circ} 19.05^{\prime} \mathrm{S}, 131^{\circ} 0.08^{\prime} \mathrm{E}, 20.12 .1992$. Leg. R.C. Willan \& G. Robertson (NTM P.32626, 4 s.v.); Darwin, central section of Casuarina Beach, $12^{\circ} 21^{\prime} \mathrm{S}, 130^{\circ} 53.03^{\prime} \mathrm{E}, 02.1993$. Leg. R.C. Willan (NTM P.30734, 3 s.v.); $12^{\circ} 21^{\prime} S, 130^{\circ} 53.03 ' E, 04.1993$. Leg. R.C. Willan (NTM P.24793, 1 s.v.); $12^{\circ} 21^{\prime}$ S, $130^{\circ} 53.03^{\prime} \mathrm{E}$, 10.1993. Leg. R.C. Willan (NTM P.2817, 4 p.v.); $12^{\circ} 21^{\prime} \mathrm{S}, 130^{\circ} 53.03^{\prime} \mathrm{E}, 02.1994$. Leg. R.C. Willan (NTM P.3543, 1 p.v.); $12^{\circ} 21^{\prime} \mathrm{S}, 130^{\circ} 53.03^{\prime} \mathrm{E}, 01.1995$. Leg. R.C. Willan (NTM P.6269, 2 s.v.); 12²1'S, $130^{\circ} 53.03^{\prime} \mathrm{E}$, 12.1995. Leg. R.C. Willan (NTM P.8110, 3 p.v., 6 s.v.); $12^{\circ} 21^{\prime} \mathrm{S}, 130^{\circ} 53.03^{\prime} \mathrm{E}, 08.04 .1996$. Leg. R.C. Willan \& M.E. Chaddock (NTM P.9957, 1 p.v., 3 s.v.); 12²1'S, 130 53.03'E, 02.1998. Leg. R.C. Willan (NTM P.10578, 1 p.v., 4 s.v.); $12^{\circ} 21^{\prime} \mathrm{S}, 130^{\circ} 53.03^{\prime} \mathrm{E}, 11.1999$. Leg. R.C. Willan (NTM P.13696, 3 p.v., 7 s.v.); 12²1'S, $130^{\circ} 53.03^{\prime} \mathrm{E}, 06.2000$. Leg. R.C. Willan (NTM P.17293, 17 p.v.); $12^{\circ} 21^{\prime} \mathrm{S}, 130^{\circ} 53.03^{\prime} \mathrm{E}, 03.2002$. Leg. R.C. Willan (NTM P.19683, 1 p.v.); 12²1'S, $130^{\circ} 53.03^{\prime} \mathrm{E}, 03.2004$. Leg. R.C. Willan (NTM P.27733, 2 p.v.); $12^{\circ} 21^{\prime} S$, $130^{\circ} 53.03^{\prime} \mathrm{E}, 06.2004$. Leg. R.C. Willan (NTM P.32883, 2 p.v.); $12^{\circ} 21^{\prime} \mathrm{S}, 130^{\circ} 53.03^{\prime} \mathrm{E}, 06.2007$. Leg. R.C. Willan 
(NTM P.45131, 3 p.v., 3 s.v.); Casuarina Beach, Dripstone Caves area, $12^{\circ} 21.08^{\prime} \mathrm{S}, 130^{\circ} 51.08^{\prime} \mathrm{E}, 05.08 .1992$. Leg. R.C. Willan (NTM P.14998, 5 s.v.); $12^{\circ} 21.08^{\prime}$ S, $130^{\circ} 51.08^{\prime} \mathrm{E}, 10.1992$. Leg. R.C. Willan (NTM P.8361, 4 s.v.); $12^{\circ} 21.08^{\prime} \mathrm{S}, 130^{\circ} 51.08^{\prime} \mathrm{E}, 12.1992$. Leg. R.C. Willan (NTM P.14705, 7 s.v.); Darwin, Vesteys Beach, southern end of Fannie Bay, $12^{\circ} 26.2^{\prime} \mathrm{S}, 130^{\circ} 49.4^{\prime} \mathrm{E}$, sandy beach, 14-17.07.2014/ Leg. J.J. ter Poorten (TP 4466, 1 s.v.); Darwin, Nightcliff, $12^{\circ} 23^{\prime} \mathrm{S}, 130^{\circ} 50^{\prime} \mathrm{E}, 09.1990$. Leg. A. Klishands (WAM S78167, 1 s.v.); Darwin Harbour, northern end of Fannie Bay, 12²5.1'S, 130 49.6'E, 1.5 $\mathrm{m}$, 07.07.1993. Leg. R.S. Williams (NTM P.24527, 1 p.v.); Darwin Harbour, 200 metres SW. of Dudley Point, "Dudley Bommies" dive site, $12^{\circ} 25^{\prime} \mathrm{S}, 130^{\circ} 48.4^{\prime} \mathrm{E}$, $4 \mathrm{~m}, 12.08 .1992$. Leg. R.C. Willan (NTM P.16350, 1 s.v.); Darwin Harbour, W. side of entrance to West Arm, rocky/coral reef S.E. of Swires Bluff, $12^{\circ} 31.2^{\prime} \mathrm{S}$, 13047.6'E, 08.10.1994. Leg. R.C. Willan (NTM P.19207, 2 p.v.); Darwin Harbour, S.E. edge of East Point Reef, $12^{\circ} 25^{\prime} \mathrm{S}, 130^{\circ} 47^{\prime} \mathrm{E}, 8 \mathrm{~m}, 27.07 .1992$. Leg. R.C. Willan (NTM P.29986, 1 s.v.); Darwin Harbour, East Point, $12^{\circ} 25^{\prime} \mathrm{S}, 130^{\circ} 47^{\prime} \mathrm{E}, 28.09 .1992$. Leg. R.C. Willan \& M.M. Burke (NTM P.14023, 2 p.v.); Darwin Harbour, East Arm, off breakwall to East Arm Port, $12^{\circ} 29.51^{\prime} \mathrm{S}$, $130^{\circ} 52.98^{\prime} \mathrm{E}, 4 \mathrm{~m}, 21.08 .1998$. Leg. R.C. Willan (NTM P.11225, 1 s.v.); Darwin Harbour, East Arm, $12^{\circ} 30^{\prime} \mathrm{S}$, 13054'E, 23.12.1995. Leg. A. Klishands (WAM S78179, 1 p.v.); Darwin Harbour (TP 955, 1 p.v.); Darwin Harbour, NW. of Wickham Point, $12^{\circ} 30.3^{\prime} \mathrm{S}, 130^{\circ} 50.5^{\prime} \mathrm{E}$, 7 m, 14.07.1993. Leg. R.S. Williams (NTM P.24550, 2 s.v.); Darwin, 09.1987. Leg. C.C. Nengerman (ZMA. MOLL.106337.1); S.E. coast of Bynoe Harbour, W. of Dawson Rock, 3 km S.E. of Rankin Point, $12^{\circ} 42.207^{\prime} \mathrm{S}$, 130³5.459'E, 6-7 m, 27.04.2007. Leg. R.C. Willan (NTM P.38438, 1 p.v.); Tiwi, N.W. tip of Melville Island, coast $4 \mathrm{~km} \mathrm{E}$. of Cape Van Diemen, $11^{\circ} 10.5^{\prime} \mathrm{S}$, $130^{\circ} 24.5^{\prime}$ E, 28.09.1996. Leg. R.C. Willan (NTM P.8906, 3 s.v.); N.W. coast of Melville Island, sand dunes at Piper Head, mouth of Apsley Strait, $11^{\circ} 16^{\prime} \mathrm{S}, 130^{\circ} 22.55^{\prime} \mathrm{E}$, 06.06.1999. Leg. J.A. Risler (NTM P.12219, 1 s.v.); off NW. tip of Melville Island, Mermaid Straits, 8 km NW. of Cape Van Diemen, Pirritadirri (= Seagull Island), 11ㅇ․66'S, $130^{\circ} 19.809 ' \mathrm{E}, 28.09 .1996$. Leg. R.C. Willan (NTM P.9105, 1 s.v.).

Australia: Western Australia: Bonaparte Gulf, Tranquil Bay, $13^{\circ} 56^{\prime} \mathrm{S}, 127^{\circ} 18^{\prime} \mathrm{E}$, intertidal rocks, 0-1 m, 13.08.1991. Leg. C.W. Bryce, WAM Kimberley Islands \& Reefs Survey 1991, Stn 4 (WAM S56805, 1 p.v.); Kimberley, Malcolm Island, $1^{\circ} 31^{\prime} \mathrm{S}, 125^{\circ} 54^{\prime} \mathrm{E}$, 31.10.1976, Leg. F.E. Wells, WAM Admiralty Gulf Mangal Survey 1976 (WAM S66947, 1 s.v.); Institut Islands, Corneille Island, $14^{\circ} 11^{\prime} 18^{\prime \prime S}, 125^{\circ} 43^{\prime} 58^{\prime \prime E}$, 19.07.1988, Leg. F.E. Wells \& C.W. Bryce (WAM S56824, 2 p.v.); Coronation Islands, $14^{\circ} 58^{\prime} \mathrm{S}, 124^{\circ} 55^{\prime} \mathrm{E}$, 28.08.1971. Leg. L.A. Smith (WAM S56804, 1 s.v.); Canning, S. of Roebuck Bay, Admiral Bay, Cape
Bossut, Paspaley Company operations dump site for pearl shells, $18^{\circ} 48^{\prime} \mathrm{S}, 121^{\circ} 31^{\prime} \mathrm{E}, 23.11 .1993$. Leg. A.Y. Williams (NTM P.21220, several p.v.); Pilbara Nearshore/Offshore, Montebello Islands, Main Bay, Trimouille Island, 20²4'13"S, 115³4'05"E, 23.08.1993. Leg. S.M. Slack-Smith, WAM Montebellos Islands Survey 1993, Stn MB/93/32B (WAM S84239, 1 p.v., A); 'Pilbara Coast'. Leg. B. \& J. Ball (WAM S70893, 3 p.v., 7 s.v.); Shark Bay, Dirk Hartog Island, Leg. A. Bassett, ex coll. P.L. van Pel (ZMA.MOLL.80974, 1 p.v.); South Passage, in sand and weed, 3-5 m, 2001. Leg. H. Morrison (TP 1166, 2 p.v.); South Passage, in sand and rubble, 5-10 m, 03.1999. Leg. H. Morrison (TP 4456, 1 p.v.); Steep Point, 2609'S, $113^{\circ} 09^{\prime} \mathrm{E}, 03.1986$. Leg. F.E. Wells \& C.W. Bryce (WAM S66948, 1 p.v.); Peron Peninsula, Broadhurst Bight, circa 3 miles offshore, 8 m, 21.02.1982. Leg. P.L. van Pel (ZMA.MOLL.80875, 1 p.v.); Monkey Mia, 09.1987. Leg. P.L. van Pel (ZMA. MOLL.80911).

\section{DESCRIPTION}

Shell large (L 40-55 $\mathrm{mm}$ ), rather thin and fragile, equilateral and almost circular. Some specimens with slight posterior elongation. Between 33-48 small and weakly developed radial ribs. Interstices wide and flat. Lunule large with small lunular heart. Exterior tan, lilac posteriorly and a deep purple umbonal tip, occasionally yellow with brown zigzag lines. Interior generally much deeper coloured than exterior, often with purple posterior half and regularly concentric purple stripes with a white or yellowish umbonal cavity and a radial purple stripe. Periostracum thick, along posterior sides of the ribs, absent on anterior sides.

\section{DISTRIBUTION AND ECOLOGY}

In WA and NT, Fulvia laevigata is typically confined to continental coastal waters (Figure 19E) and is very common in the Darwin area. It is found in turbid shallow water and it seems to inhabit protected littoral habitats like bays, lagoons and estuaries with soft bottoms (ter Poorten 2009). It is widely distributed in the Central IWP.

\section{REMARKS}

This species has likely been mistaken for the superficially similar Fulvia aperta (Bruguière, 1789). Wilson and Stevenson (1977: 53-54) observed this similarity, suggesting that Cardium papyraceum Bruguière, 1789 might be a junior synonym of $F$. aperta. However, Vidal (1994) argued that two different species are involved and demonstrated (Vidal 1999) that $F$. papyraceum must be considered a junior synonym of F. laevigata (Linnaeus, 1758). The Shark Bay samples are the southernmost records. It is also known from the southern Indonesian Roti Island (ZMA, Siboga Exped., Stn 299, 1 p.v., det. TP), taken from a mud bottom. 


\section{Fulvia scalata Vidal, 1994}

Figures $11 \mathrm{P}-\mathrm{T}$, $19 \mathrm{~F}$

Fulvia (Fulvia) scalata Vidal, 1994: 108-109, pl. 1 figs $3-4$, pl. 3 figs $5 \mathrm{a}-\mathrm{b}, 7$.

Fulvia (Fulvia) scalata Vidal, 1994 - Lamprell and Healy 1998: 246, fig. 741; ter Poorten 2009: pl. 13 figs 8-10, pl. 15 fig. 2; Huber 2010: 305, fig.; ter Poorten 2011: pl. 1110 figs $7-8$.

\section{MATERIAL EXAMINED}

Australia: Western Australia: North West Shelf, Rowley Shoals, S.E. of Mermaid Reef, $17.4872^{\circ}$ S, $120.4606^{\circ} \mathrm{E}$ to $17.4954^{\circ} \mathrm{S}, 120.4679^{\circ} \mathrm{E}, 184-187 \mathrm{~m}$, 20.06.2007. Leg. C. Whisson \& O. Gomez, CSIRO RV 'Southern Surveyor' Cruise, Stn SS0507/091 (WAM S34673, 5 s.v.); 100 miles N.W. of Port Hedland, 18 ${ }^{\circ} 47^{\prime}$ S, $117^{\circ} 58^{\prime}$ E, 154 m, 28.03.1982. Leg. L.M. Marsh, CSIRO FRV 'Soela' Cruise II 1982, Stn SO2/82/10A (WAM S56827, 1 s.v.; WAM S57158, 16 s.v.).

Literature records: Vidal (1994): Dampier (QM, 1); ALA / OZCAM: 71 nautical miles N.N.W. of Dampier (AMS C.172915, det. J. Vidal).

\section{DESCRIPTION}

Shell small (L 15-21 mm), rather thin, rounded to subquadrangular, inflated, roughly equilateral. Between 40-45 well delimited radial ribs, particularly on posterior third of the shell. Commarginally aligned granules present in the interstices of the anterior and posterior slopes, close-set and placed like steps of a ladder - hence the species' name. Periostracal insertions rather weak, mainly on the posterior limit of the ribs. Very large and broad lunular heart. Exterior and interior generally uniform pale brown to pinkish, often evenly covered with slightly darker maculations.

\section{DISTRIBUTION AND ECOLOGY}

Consistent with other non-Australian records that indicate a wide geographic range and affinity for deep water, the WA records of Fulvia scalata were found close to the continental shelf edge off the northern coast (depth range 154-187 m, based on single valves; Figure 19F). This species is also reported from QLD (Vidal 1994; WAM S78360) and the Gulf of Carpentaria (Vidal 1994; Lamprell and Healy 1998). It is a tropical deep water species, widely distributed in the IWP.

\section{REMARKS}

The typical ladder-like sculpture present in the interstices of the posterior slope and the relatively well developed radial ribs on the posterior slope, easily differentiate this species from its congeners. The holotype is figured for comparison (MNHNIM-2000-4021, Figure 11T).

\section{Fulvia undatopicta (Pilsbry, 1904)}

Figures 11U-Y, $19 \mathrm{G}$

Cardium hungerfordi undatopictum Pilsbry, 1904: 556, pl. 40 figs $14-15$.

Cardium hungerfordi stigmaticum Pilsbry, 1904: 556557, pl. 41 figs 13-14.

Fulvia (Fulvia) undatopicta (Pilsbry, 1904) - Lamprell and Healy 1998: 246, fig. 742.

Fulvia (Laevifulvia) undatopicta (Pilsbry, 1904) - ter Poorten 2009: pl. 14 figs 1-4; Huber 2010: 305, fig.; ter Poorten 2011: pl. 1110 figs 1-2.

\section{MATERIAL EXAMINED}

Australia: Western Australia: Canning, W. of Broome, $17^{\circ} 58^{\prime} \mathrm{S}, 122^{\circ} 14^{\prime} \mathrm{E}, 90 \mathrm{~m}, 21.12 .1969$. Leg. K. Ozawa, Tokyo University of Fisheries Exped. FV 'Umataka Maru', Stn UMD6927 (WAM S57166, 1 s.v.); Pilbara Offshore, 38 nautical miles N. of Port Walcott, $19^{\circ} 59^{\prime} \mathrm{S}, 117^{\circ} 16^{\prime} \mathrm{E}$ to $20^{\circ} 01^{\prime} \mathrm{S}, 117^{\circ} 16^{\prime} \mathrm{E}, 50-52$ m, 15.04.1982. Leg. L.M. Marsh, CSIRO FRV 'Soela' Cruise II, Stn SO2/82/54A (WAM S78297, 1 s.v.); Exmouth Gulf, $14 \mathrm{~km}$ E. of Muiron Islands, Hawksbill Exploration Field, $21^{\circ} 41^{\prime} \mathrm{S}, 114^{\circ} 31^{\prime} \mathrm{E}, 15 \mathrm{~m}, 05.12 .1993$. Leg. Apache Energy (WAM S78338, 1 p.v., A).

Literature records: Vidal (1994): Gulf of Carpentaria (AMS, 1).

\section{DESCRIPTION}

Shell small (H 10-19 mm), thin, roughly equilateral and rounded ovate, a little truncated posteriorly; height generally slightly exceeds length. Between 46-53 radial ribs; a few strong ribs on posterior part of the shell, weak anteriorly, almost smooth elsewhere. Scattered granulations present, often more or less commarginally aligned, especially on antero-ventral part of the shell. Internal marginal crenulations usually clearly defined. Lunular heart rather small, elongated. Colour extremely variable, often whitish with irregular reddish brown streaks or spots, at times with four reddish spots or streaks forming a cross.

\section{DISTRIBUTION AND ECOLOGY}

All three samples of this wide-ranging tropical IWP species come from the northern coastal area of WA (Figure 19G) in 15-90 metres depth (found alive at 15 metres depth). This species is known from QLD and the Gulf of Carpentaria (Vidal 1994; Lamprell and Healy 1998) but so far has not been recorded from WA.

\section{REMARKS}

The presence in the Gulf of Carpentaria is based on a historical sample (AMS C.15313, $16^{\circ} 58^{\prime} \mathrm{S}, 140^{\circ} 53^{\prime} \mathrm{E}$, 05.06.1903. Leg. C. Hedley, det. J. Vidal) and needs to be confirmed by more recent finds. 
The subgenus Laevifulvia Vidal, 1994 has been shown to be paraphyletic with recent molecular research (Herrera et al. 2015) demonstrating that $F$. undatopicta is well rooted in a clade with other Fulvia species, whereas $F$. hungerfordi, also placed in subgenus Laevifulvia by Vidal (1994), forms a separate clade. Recently, Laevifulvia was synonymised with Fulvia by ter Poorten and Hylleberg (2017), based on morphological characters.

\section{Genus Laevicardium Swainson, 1840}

Laevicardium Swainson, 1840: 373 (as a subgenus of Cardium). Type species by subsequent designation (Stoliczka, 1870: xviii, 209): Cardium oblongum Gmelin, 1791; Recent, 'mari mediterraneo' ('Mediterranean').

Liocardium Agassiz, 1846: 199, 212 (unnecessary emendation of Laevicardium Swainson, 1840).

\section{'Laevicardium' lobulatum (Deshayes, 1855)}

Figures $7 \mathrm{~N}-\mathrm{U}$

Cardium lobulatum Deshayes, 1855: 332.

Laevicardium multipunctatum (Sowerby in Broderip \& Sowerby, 1833) - Lamprell and Whitehead 1992: pl. 33 fig. 223.

Fulvia (Laevifulvia) imperfecta Vidal \& Kirkendale, 2007: 92-93, figs 3j-1.

Laevicardium lobulatum (Deshayes, 1855) - Huber 2010: 303, fig.

'Laevicardium' lobulatum (Deshayes, 1855) - ter Poorten 2009: pl. 14 figs 15-18, pl. 15 figs 5-6; pl. 16 figs 13-15; ter Poorten 2011: pl. 1114 figs 1-3.

\section{MATERIAL EXAMINED}

Australia: Western Australia: Oceanic Shoals, Rowley Shoals, Clerke Reef, 17¹7'51.826"S, $119^{\circ} 21^{\prime} 32.899 " E, 15 \mathrm{~m}$, lagoon (patch reef), 07.10.2014. Leg. L. Kirkendale \& C. Bryce, Woodside Kimberley Survey 2014, Stn 155/K14 (WAM S68164, 1 p.v., A).

\section{DESCRIPTION}

Shell medium sized (H $25-35 \mathrm{~mm})$, rather solid, inequilateral, elongately oblique. Juveniles more rounded-quadrangular, less inflated and relatively thin. Margins rounded, except for a short posterior straightening or indentation, better developed in adults. Shell surface glossy and smooth with minute growth lines. On the medio-posterior part these lines are crossed by approximately six weakly developed ribs, creating a finely undulating pattern. Internal margin carrying about 70-95 crenulations. Lunule elongate, slightly protruding. Hinge long and arched. Exterior cream with brown radial or inverted v-shaped markings, occasionally with a zigzag pattern and with margins usually lighter coloured. Interior often darker reddishbrown. Hinge plate chocolate brown to purple. A well developed pattern with differences in translucency is present in the juvenile stage (Figures $7 \mathrm{~N}-\mathrm{Q}$ ).

\section{DISTRIBUTION AND ECOLOGY}

This juvenile live-taken specimen from the oceanic emergent reefs is the first WA record of this species. The lagoonal occurrence is in line with the other records from sheltered shallow water habitat in bottoms of sand, silt and mud. Also known from QLD (Hedley 1909, 1910; WAM, NTM, AMS colln) and widely distributed in the Central IWP.

\section{REMARKS}

For comparison, figures of the three syntypes are given (NHMUK 1974135, Figures 7R-U). Recent molecular phylogenetic research by Herrera et al. (2015) demonstrates that this species is unrelated to other species in the genus Laevicardium, as first noted by ter Poorten (2009), who identified this discrepancy based on differences in microsculptural details. Together with Fulvia lineonotata Vidal, 1994, these two species currently represent a distinct lineage, superficially similar to other Laevicardium based on gross shell shape, but unrelated as indicated by molecular work and subtle morphological characters. The adjusted generic assignment will be presented elsewhere. The 'smooth' appearance is likely due to convergent evolution, having evolved in separate lineages as adaptations to a similar lifestyle (of burrowing) and a misleading character for phylogenetic inference.

\section{Subfamily Trachycardiinae Stewart, 1930}

\section{REMARKS}

Based on molecular analysis, Trachycardiinae forms a monophyletic group (Herrera et al. 2015), confirming earlier findings by Keen (1969) and Schneider and Carter (2001), based on shell morphology and microstructure, respectively. Only two genera: Acrosterigma and Vasticardium occur in the study area covered in this paper.

\section{Genus Acrosterigma Dall, 1900}

Acrosterigma Dall, 1900: 1073, 1090 (as a section of Trachycardium). Type species by original designation: Cardium dalli Heilprin, 1887; Caloosahatchee Formation, Pliocene, Florida, U.S.A. 


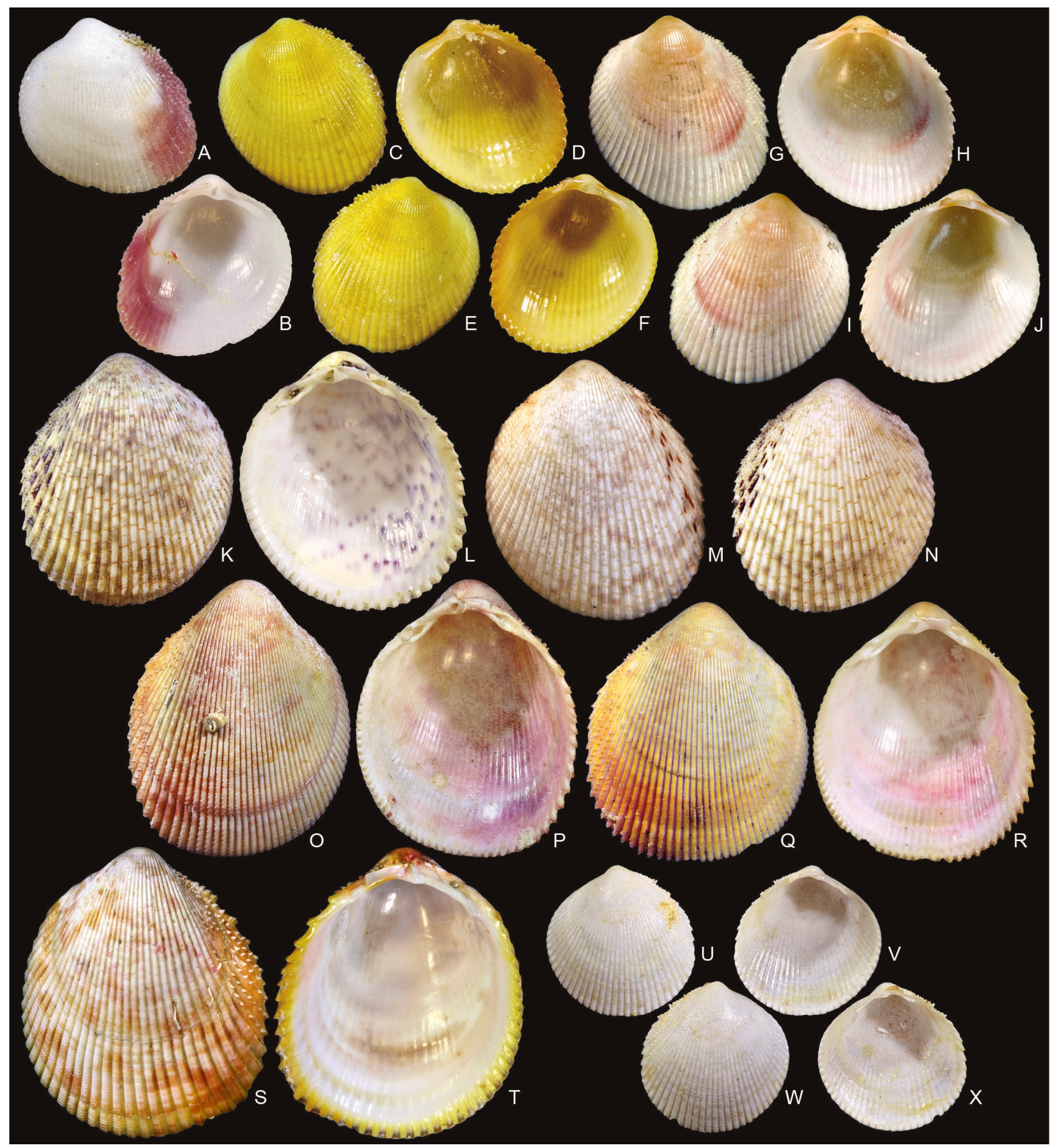

FIGURE 12 A, B, C, D, E, F, G, H, I, J, Acrosterigma dianthinum (Melvill \& Standen, 1899). A-B, Ashmore Reef, WA: WAM S91665, length $8.2 \mathrm{~mm}$. A, exterior of I.V., B, interior of I.v.; C-F Vulcan Shoal, WA, WAM S91854, length $7.9 \mathrm{~mm}$. C, exterior of I.v., D, interior of r.V., E, exterior of r.v., F, interior of I.v.; G-J, Torres Strait, QLD: NHMUK 1899.2.23.11, syntype, height $13.7 \mathrm{~mm}$. G, exterior of I.v., H, interior of r.v., I, exterior of r.V., J, interior of I.V.

K, L, M, N, Acrosterigma punctolineatum Healy \& Lamprell, 1992. K-L, Yankawingarri Island, WA: WAM S56950, height $30.6 \mathrm{~mm}$. K, exterior of I.v., L, interior of I.v.; M, Largest of the three possible syntypes of Cardium foveolatum G.B. Sowerby II, 1840, 'Swan River', WA [erroneous]: NHMUK 1996514, height $32.0 \mathrm{~mm}$, exterior of I.v.; N, Condillac Island, WA: WAM S56949, height $28.6 \mathrm{~mm}$, exterior of r.v.

O, P, Q, R, Acrosterigma suduirautiVidal \& ter Poorten, 2007. Rowley Shoals, WA: WAM S32883. O-P, height $37.5 \mathrm{~mm}$, Q-R, height $31.5 \mathrm{~mm}$; O, exterior of r.v., P, interior of r.V., Q, exterior of r.v., R, interior of r.v.

S, T, Acrosterigma variegatum (G.B. Sowerby II, 1840). Ningaloo Marine Park, WA, WAM S43505, height $56.6 \mathrm{~mm}$. S, exterior of I.V., T, interior of I.v.

$\mathrm{U}, \mathrm{V}, \mathrm{W}, \mathrm{X}$, Acrosterigma simplex (Spengler, 1799). Montebello Islands, WA, WAM S78358, height $4.2 \mathrm{~mm}$. U, exterior of I.V., V, interior of I.V., W, exterior of r.V., $X$, interior of r.v. 


\section{Acrosterigma dianthinum (Melvill \& Standen, 1899)}

Figures 12A-J, 20A

Cardium (Trachycardium) dianthinum Melvill \& Standen, 1899: 190, pl. 11 figs 25, 25a.

Arosterigma dianthinum (Melvill \& Standen, 1899) - Lamprell and Whitehead 1992: pl. 30 fig. 195 [= NHMUK 1899.2.23.11 syntype].

Acrosterigma dianthinum (Melvill \& Standen, 1899) ter Poorten 2009: pl. 1 figs 6-8; ter Poorten 2011: pl. 1088 figs $1-2$.

\section{MATERIAL EXAMINED}

Australia: Western Australia: Oceanic Shoals, Vulcan Shoal, 1247'57.481"S, $124^{\circ} 16^{\prime} 00.205^{\prime \prime E}, 19 \mathrm{~m}$, 06.10.2013. Leg. L. Kirkendale \& C. Bryce, Woodside Kimberley Survey 2013, Stn 146/K13 (WAM S91854, 1 p.v.); E. end, $12^{\circ} 14^{\prime} 37.282^{\prime \prime S}, 1^{\circ} 3^{\circ} 14^{\prime} 37.286^{\prime \prime E}, 15 \mathrm{~m}$, 01.10.2013. Leg. L. Kirkendale \& C. Bryce, Woodside Kimberley Survey 2013, Stn 135/K13 (WAM S91666, 1 s.v.; WAM S91667, 1 s.v.); E. side, $12^{\circ} 12^{\prime 27.901 " S, ~}$ $123^{\circ} 08^{\prime} 44.268^{\prime \prime E}, 15$ m, 03.10.2013. Leg. L. Kirkendale \& C. Bryce, Woodside Kimberley Survey 2013, Stn 140/ K13 (WAM S91668, 2 p.v., A); S. side, 12¹7'36.6"S, $123^{\circ} 07^{\prime} 25.441^{\prime} E, 12$ m, 28.09.2013. Leg. L. Kirkendale \& C. Bryce, Woodside Kimberley Survey 2013, Stn 128/ K13 (WAM S91665, 1 s.v.); S. Scott Reef, outer slope, Sandy Islet, N. side, $14^{\circ} 02.526^{\prime} \mathrm{S}, 121^{\circ} 45.688^{\prime} \mathrm{E}, 6-13 \mathrm{~m}$, 20.09.2006. Leg. C. Bryce \& C. Whisson, WAM NWA Shelf Atolls Survey September 2006, Stn 22 (WAM S31136, 1 s.v.).

\section{DESCRIPTION}

Shell small (L 10-15 $\mathrm{mm}$ ), rather thin, very inequilateral, transversally ovoid, and moderately inflated. Between 42-50 flat and low radial ribs, most anterior ones finely ornamented with scales, most posterior ones spined. Ribs possessing characteristic, regularly disposed granules on their tops, visible under magnification and skimming light. Lunule small and elongate. External coloration uniformly white to cream, often with scattered brownish blotches, posterior part often purple, ligamental nymph and umbonal cavity orange-yellow. Internal coloration similar by transparency.

\section{DISTRIBUTION AND ECOLOGY}

All WA records of this species are from the northern offshore reefs (Figure 20A). This small species is well known throughout the Central and Western Pacific, as indicated by records from the Coral Triangle up to Vanuatu, New Caledonia and across southern QLD. Acrosterigma dianthinum has been repeatedly collected alive in sandy shallow water environments among corals.

\section{REMARKS}

WAM S91854 (Figures 12C-F) is an atypical and monochromatic yellow-coloured specimen, a coloration that occasionally occurs in other genera as well, with examples known from Afrocardium (Figure 7H), Corculum, Fragum, Frigidocardium, Fulvia, Pratulum, Tridacna and Vasticardium.

\section{Acrosterigma extremattenuatum sp. nov. ter Poorten \& Kirkendale}

Figures 13A-H, 14, 20B

urn:Isid:zoobank.org:act:0C5E8807-F6D2-4CAB-B6F96379B69C6465

Laevicardium attenuatum (Sowerby, 1841) - Habe and Kosuge 1970: 154, pl. 59 fig. 10.

Laevicardium attenuatum (Sowerby, 1841) — Wilson and Stevenson 1977: 57-59, pl. 3 fig. 12, text fig. 6 [pars].

Laevicardium attenuatum (Sowerby, 1840) - Lamprell and Whitehead 1992: pl. 33 fig. 221, cover fig.

Acrosterigma attenuatum (Sowerby, 1841) — Vidal 1999: 327-329, fig. 20 [pars].

\section{MATERIAL EXAMINED}

Holotype

Australia: Western Australia: Pilbara Offshore, 7 miles N. of Long Island, off Onslow, $21^{\circ} 31^{\prime} \mathrm{S}, 114^{\circ} 40^{\prime} \mathrm{E}$, fine sand and rubble, $51.2 \mathrm{~m}, 17.06 .1960$. WA Hawaiian Exped. (WAM S84456, ex 1067-66 [shell] / 1076-66 [label], 1 s.v.).

\section{Paratypes}

Australia: Northern Territory: Arafura Sea, off Darwin. Ex coll. A.R. Cahn, 1958 (ANSP 219279, 1 p.v., paratype).

Australia: Western Australia: Pilbara Offshore, East Pilbara, Port Hedland-De Grey River mouth area. Leg. M. Claydon (TP 4460, 1 p.v., paratype); E. of Dampier, Nickol Bay, trawled by shrimper, c. 30 m (RMNH.5004012, 1 p.v., paratype); 7 miles N. of Long Island, off Onslow, $21^{\circ} 31^{\prime} \mathrm{S}, 114^{\circ} 40^{\prime} \mathrm{E}$, fine sand and rubble, $51.2 \mathrm{~m}, 17.06 .1960$. WA Hawaiian Exped. (WAM S66298, ex 1067-66 [shell] / 1076-66 [label], 1 s.v., paratype); Ningaloo, off Osprey Reef, $22^{\circ} 10.279^{\prime} \mathrm{S}, 22^{\circ} 10.489^{\prime} \mathrm{S}, 113^{\circ} 49.163^{\prime} \mathrm{E}-113^{\circ} 49.103^{\prime} \mathrm{E}$, epibenthic sled, sand, 71.4-73.0 m, 28.04.2006. Leg. M.P. Salotti, AIMS-WAM RV 'Cape Ferguson' Ningaloo Survey I April/May 2006, Stn CF4010\&11/2006/D013 (WAM S84454, 1 s.v., paratype).

\section{Other materials}

Australia: Queensland: 'off Lucinda, trawled 6080 m' [locality questionable] (S. Hobbs, U.S.A., 2 p.v.); Torres Strait, Torres Strait Biodiversity, Stn TS80006631, (QM, 1 p.v., A); Wellesley, S.E. corner of 


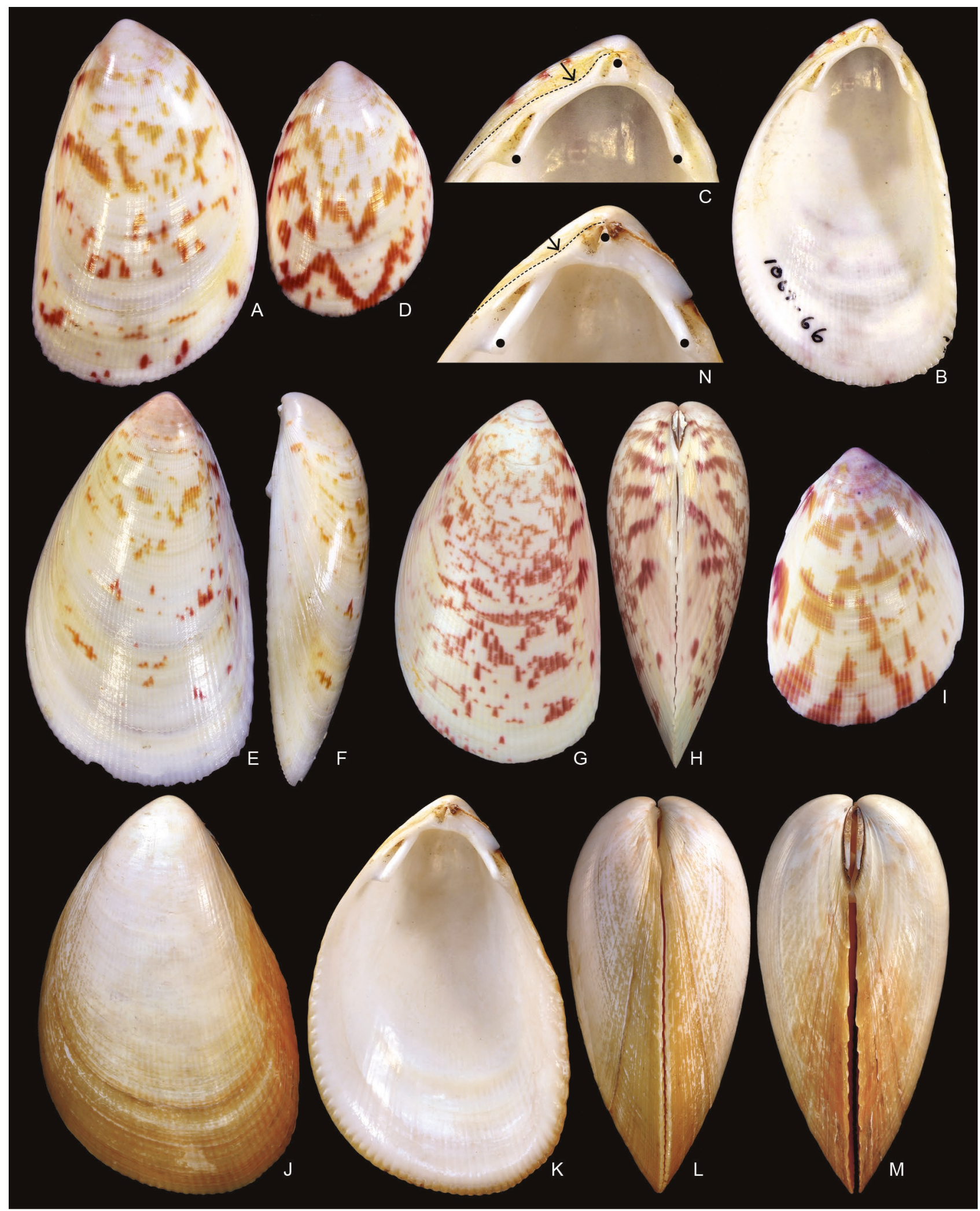

FIGURE 13 A, B, C, D, E, F, G, H, Acrosterigma extremattenuatum sp. nov. A-D, off Onslow, WA. A-C, WAM S84456, holotype, H $46.5 \mathrm{~mm}$. A, exterior of r.v., B, interior of r.v., C, hinge of r.V.; D, WAM S66298, paratype, height 32.3 mm, exterior of r.v.; E-F, Ningaloo Marine Park, WA: WAM S84454, paratype, height 60.8 mm. E, exterior of I.v., F, anterior; G-H, Port Hedland-De Grey River mouth area, WA, TP 4460, paratype, height $54.8 \mathrm{~mm}$. G, exterior of I.v., H, posterior.

I, J, K, L, M, N, Acrosterigma attenuatum (G.B. Sowerby II, 1841). I, Aru, Indonesia, WAM S67690, height $35.0 \mathrm{~mm}$, exterior of r.v.; J-N, 'Ceylon' (description), 'Ceylon, Zanzibar, Philippines' (label): NHMUK 197126, lectotype, height $77.0 \mathrm{~mm}$. J, exterior of I.v., K, interior of r.V., L, anterior, M, posterior, N, hinge of r.v. 


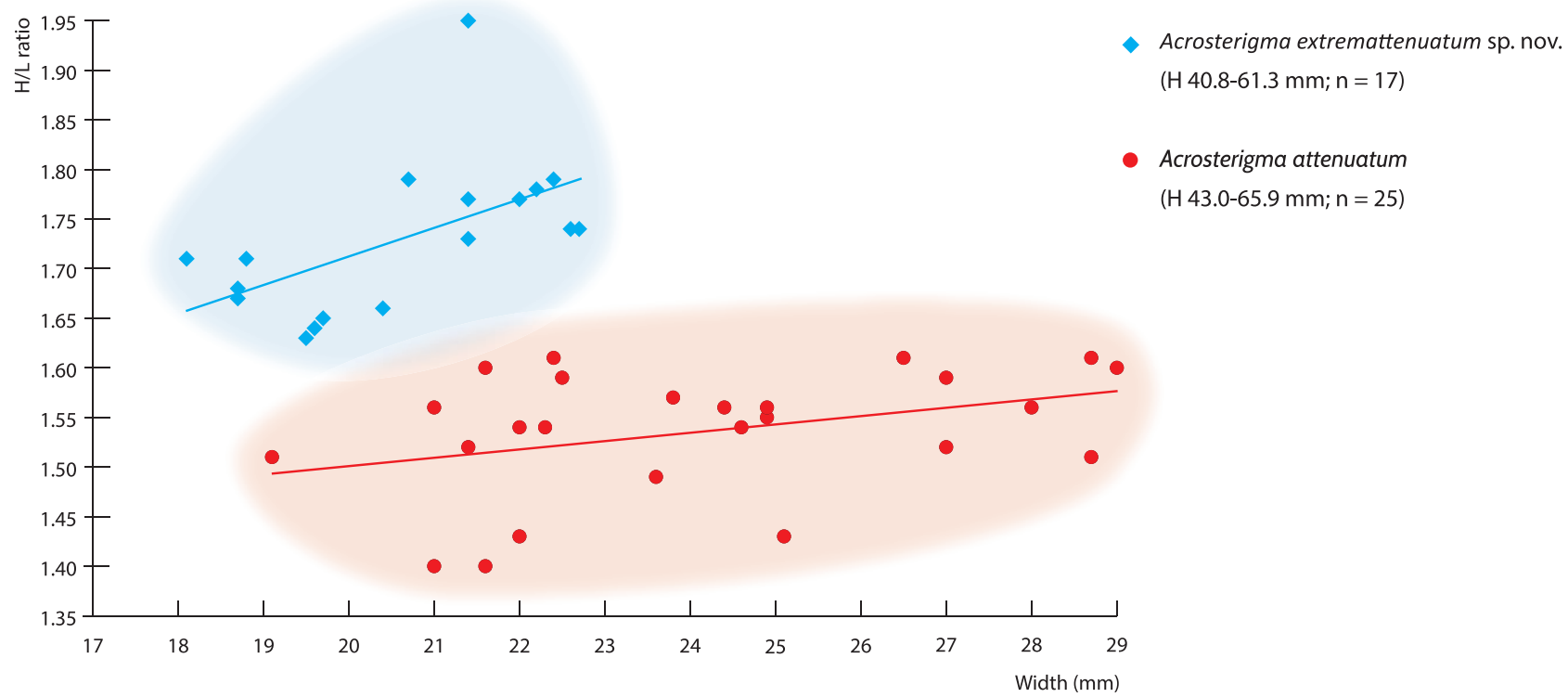

FIGURE 14 Scatter diagram showing the relation of shell width (horizontal axis) and $\mathrm{H} / \mathrm{L}$ ratio (vertical axis) for Acrosterigma extremattenuatum sp. nov. (blue diamonds, $n=17$ ) and $A$. attenuatum (red circles, $n=25$ ). Only (sub)adult shells are plotted, defined as all those individuals with a height of at least $40 \mathrm{~mm}$. Colln ANSP, MNHN, WAM, TP, UF, ZMA, S. Hobbs, E. Kaptein and H. van Rij.

Gulf of Carpentaria, $16^{\circ} 19^{\prime} 25.0^{\prime \prime} \mathrm{S}, 139^{\circ} 09^{\prime} 10.0^{\prime \prime} \mathrm{E}$, trawl, 20 m, 22.02.1965. Leg. CSIRO Fisheries, CSIRO 'Rama' Gulf of Carpentaria Prawn Survey 1965, Stn RAMA \#1782 (WAM S84465, 1 s.v.; WAM S84231, 1 p.v., A).

Australia: Northern Territory: Arafura Sea, by Taiwan fishing boats. Ex coll. Lan (UF 472551, 1 p.v.)

Australia: Western Australia: Canning, 10-20 miles W. of Lagrange Bay, $18^{\circ} 39^{\prime} \mathrm{S}, 121^{\circ} 42^{\prime} \mathrm{E}$, dredged, 20-45 m, 13.10.1962. Leg. R.W. George, FRV 'Dorothea' Cruise 1962 (WAM S56792, ex 928-66, 1 s.v.); North West Shelf, 40 miles W. of Cape Jaubert, $18^{\circ} 56^{\prime} \mathrm{S}, 120^{\circ} 55^{\prime} \mathrm{E}$, dredged, sponge bottom, $40 \mathrm{~m}, 13.10 .1962$. Leg. R.W. George, FRV 'Dorothea' Cruise 1962 (WAM S56791, ex 927-66, 1 s.v.); 60 miles N.W. of Bedout Island, $18^{\circ} 56^{\prime} \mathrm{S}, 118^{\circ} 28^{\prime} \mathrm{E}$, dredged, $50 \mathrm{~m}, 12.10 .1962$. Leg. R.W. George, FRV 'Dorothea' Cruise 1962 (WAM S56793, ex 922-66, 2 s.v.); 51 nautical miles N. of Port Hedland, $19^{\circ} 29^{\prime} \mathrm{S}, 118^{\circ} 22^{\prime} \mathrm{E}$, triangular dredge, $56 \mathrm{~m}, 01.04 .1982$. Leg. L.M. Marsh, CSIRO FRV 'Soela' Cruise II 1982, Stn SO2/82/12A (WAM S84466, 5 s.v.); 72 miles N.W. of Bedout Island, $19^{\circ} 01^{\prime} \mathrm{S}, 118^{\circ} 09^{\prime} \mathrm{E}$, dredged, $50 \mathrm{~m}$, 12.10.1962. Leg. R.W. George, FRV 'Dorothea' Cruise 1962 (WAM S56794, ex 932-66, 1 s.v.); 57 nautical miles N.W. of Port Hedland, $19^{\circ} 34.2^{\prime}$ S, $117^{\circ} 57.4^{\prime} \mathrm{E}$, trawl, sand, shell and rubble, 60-65 m, 05.10.1982. Leg. L.M. Marsh \& M. Bezant, CSIRO FRV 'Soela' Cruise V 1982, Stn S05/82/063 (WAM S84467, 2 s.v.); 67 nautical miles N.N.E. of Cape Lambert, 19³1.4'S, $117^{\circ} 26.0^{\prime} \mathrm{E}$, sled, sand, flat sponges, gorg, long hydroids,
78 m, 17.08.1995. Leg. L.M. Marsh, AIMS Survey RV 'Lady Basten'1995, Stn AIMS/95/LB3 (WAM S84461, 1 s.v.); 38 nautical miles N. of Port Walcott, $19^{\circ} 59^{\prime}$ S, $117^{\circ} 16^{\prime} \mathrm{E}$, triangle dredge, silty sand and bryozoa, 50-52 m, 15.04.1982. Leg. L.M. Marsh, CSIRO FRV 'Soela' Cruise II 1982, Stn SO2/82/54A (WAM S84460, 5 s.v.); Dampier Archipelago, 11 nautical miles N.N.E. of Legendre Island, $20^{\circ} 12.7^{\prime} \mathrm{S}, 116^{\circ} 55.3^{\prime} \mathrm{E}$, trawl, $43 \mathrm{~m}$, 17.08.1995. Leg. L.M. Marsh, AIMS Survey RV 'Lady Basten'1995, Stn AIMS/95/LB1 (WAM S84462, 4 s.v.); N. of Malus Island, $19^{\circ} 45^{\prime} \mathrm{S}, 116^{\circ} 38^{\prime} \mathrm{E}$, otter trawl, 57-60 m, 04.12.1979. Leg. L.M. Marsh \& S.M. Slack-Smith, CSIRO FRV 'Soela' Cruise I 1979, Stn SO1/79/0028 (WAM S84459, 2 s.v., 1 fragm.); Pilbara Nearshore/ Offshore, Dampier Archipelago, N. of N.W. point of Eaglehawk Island, $20^{\circ} 38.94^{\prime} \mathrm{S}, 116^{\circ} 26.22^{\prime} \mathrm{E}$, dive, very low rock ridges \& silty sand, $10 \mathrm{~m}, 03.09 .1999$. Leg. S.M. Slack-Smith et al., Woodside Dampier Exped. III 1999, Stn DA3/99/56 (WAM S84463, 1 s.v.); N.W. of Rosemary Island, $20^{\circ} 03^{\prime} \mathrm{S}, 116^{\circ} 10^{\prime} \mathrm{E}$, otter trawl, $62-65$ m, 04.12.1979. Leg. L.M. Marsh \& S.M. Slack-Smith, CSIRO FRV 'Soela' Cruise I 1979, Stn SO1/79/0036 (WAM S84464, 1 s.v.); N.E. of Montebello Islands, $19^{\circ} 54^{\prime} \mathrm{S}, 116^{\circ} 00^{\prime} \mathrm{E}$, otter trawl, 76-78 m, 03.12.1979. Leg. L.M. Marsh \& S.M. Slack-Smith, CSIRO FRV 'Soela' Cruise I 1979, Stn SO1/79/0022-23 (WAM S84468, 1 s.v.); Montebello Islands, Bunsen Channel, $\mathrm{N}$. end of Trimouille Island, $20^{\circ} 23^{\prime} 08^{\prime \prime} \mathrm{S}, 115^{\circ} 32^{\prime} 43^{\prime \prime} \mathrm{E}$, scuba, 21.08.1993. Leg. C. Bryce \& S.M. Slack-Smith, WAM Montebello Islands Survey 1993, Stn MB/93/28a 
(WAM S84457, 1 s.v.); Ningaloo, Ningaloo Marine Park, Torpedo Bay, $21^{\circ} 49.876$ 'S, $113^{\circ} 58.407^{\prime} \mathrm{E}$, epibenthic sled, 50.69-56.78 m, 05.05.2007. Leg. M.P. Salotti, AIMSWAM RV 'Cape Ferguson' Ningaloo Survey II May 2007, Stn CF4314/2007/D059 (WAM S84455, 1 s.v.); Undefined bioregion: 'Dampier, Beagle Bay' [sic], taken during low tide from six feet of water, close to shoreline in beach area, sand and seagrass with rocks bottom, 03.1979 (S. Hobbs, U.S.A., 2 p.v.); WA, before 1980, ex coll. A.P.W. Herlaar (TP 4188, 1 p.v.); WA, 1979 (H. van Rij, The Netherlands, no reg. no., 2 p.v.).

Unknown provenance: ex coll. J. Drijver (TP 4174, 2 p.v.; E. Kaptein, The Netherlands, 1104.5, 3 p.v.).

\section{DESCRIPTION}

Shell rather large for the genus (H up to $61.3 \mathrm{~mm}$ ) and solid, elongately ovate, inaequilateral, strongly elongate (H/L 1.63-1.95, $\mathrm{n}=16, \mathrm{H} 40.8-61.3 \mathrm{~mm}$, Figure 14) and highly attenuate towards the umbos, moderately inflated. Anterior and ventral margins regular rounded, posterior margin slightly convex with straight median part, postero-ventral margin angular rounded, anterodorsal marginal area bending towards the inside of the shell. Lunule well marked and strongly excavated at shell margins, valves beneath lunule slightly gaping; escutcheon hardly defined. Exterior glossy and almost smooth, very weakly radially ribbed on central part of shell disc, almost of a subsurface nature, crossed by minute commarginal growth lines; anteriorly well demarcated commarginally slightly undulating close-set riblets; posteriorly irregular, well spaced commarginally slightly undulating riblets, most expressed towards the posterior margin and largely replaced by weak radial riblets in the juvenile stage. Two well defined radial ribs present near postero-dorsal margin, carrying weakly demarcated nodules when crossed by commarginal riblets. Mean number or radial ribs 56.5 (range 51-59, $\mathrm{n}=8$ ), rib count based on internal marginal ribbing. Margins crenulated, rib impressions not extending far into the shell. Hinge typical for the genus, almost symmetrical and strongly arched, angle A (formed by r.v. ventral lateral teeth and dorsal end of cardinals) approximately $75-80^{\circ}$, cardinal socket very narrow and deep. Exterior colour dirty white to pale yellow with variable red-brown zig-zag and chevron patterns, composed of segments that are confluent with the indistinct radial ribs, less numerous but darker on posterior slope; interior white, except for light orangeyellow umbonal cavity, sometimes consisting of two broad radial bands, external coloration vaguely visible internally. Periostracum thin, light olive-green.

\section{DISTRIBUTION AND ECOLOGY}

In northern WA, this new species appears to be restricted to the inner and mid-continental shelf, and has been found most frequently off the Pilbara Coast (Figure
20B). It is appears to be a Dampierian endemic, ranging from Ningaloo to the Torres Strait. The ANSP 219279 Darwin record is considered untrustworthy (personal commumication P. Callomon, 2015) as is the QLD sample in the collection of $\mathrm{S}$. Hobbs (dealer specimens). Depth range 2-78 $\mathrm{m}$, based on dead recordings; $20 \mathrm{~m}$, live record.

\section{REMARKS}

Vidal (1999) reviewed the related species Acrosterigma attenuatum (G.B. Sowerby II, 1841). His assignment in Acrosterigma, based on morphology, has been confirmed by molecular analysis (Herrera et al. 2015) and is adopted for A. extremattenuatum sp. nov. Acrosterigma attenuatum (Figures 13I-N, 14) differs by being less elongate and attenuate (H/L 1.40-1.61, $\mathrm{n}=25$, H 43.0-65.9 mm), by being more inflated, by a yelloworange colour that is generally lacking the prominent red-brown zigzag configuration (if present, confined to the posterior slope), by a less stronger arched hinge (angle A approximately $80-90^{\circ}$ ), by a less hollowed antero-dorsal marginal area, by a less pronounced commarginal ribbing on the anterior slope and by a larger maximum size (largest observed specimen: $H$ $86.7 \mathrm{~mm}$ from Sri Lanka, RMNH, ex ZMA). Whereas a weak sterigma is present in the umbonal cavity of $40 \%$ of the investigated samples of A. attenuatum (Vidal 1999), this seems to be lacking in A. extremattenuatum sp. nov.

Only one $A$. attenuatum sample (Aru, Indonesia, WAM S67690; Figure 13I) was observed with a similar colour pattern as A. extremattenuatum sp. nov. However, it differs in being less elongate, by a less strongly arched hinge and by the absence of an inward curving, anterodorsal marginal area.

\section{ETYMOLOGY}

The specific epithet refers to the extremely elongate and dorsally attenuate shape of the shell, more than any other of its congeners (Vidal 1999: Table 2), including $A$. attenuatum (G.B. Sowerby II, 1841).

\section{Acrosterigma punctolineatum Healy \& Lamprell, 1992}

Figures $12 \mathrm{~K}-\mathrm{N}, 20 \mathrm{C}$

Acrosterigma sp. - Lamprell and Whitehead 1992: pl. 30 fig. 199 [= QM MO32905 holotype of $A$. punctolineatum].

Acrosterigma punctolineata Healy \& Lamprell, 1992: 87-89, pl. 3e-h.

Acrosterigma punctolineata Healy \& Lamprell, 1992 Lamprell and Healy 1998: 256. 
Acrosterigma punctolineatum Healy \& Lamprell, 1992 — ter Poorten 2009: pl. 1 fig. 12; Huber 2010: 297, fig.; ter Poorten 2011: pl. 1088 fig. 3.

\section{MATERIAL EXAMINED}

Australia: Northern Territory: Cobourg, Orontes Reef, off Port Essington, $11^{\circ} 16^{\prime} \mathrm{S}, 132^{\circ} 09^{\prime} \mathrm{E}, 9-12 \mathrm{~m}$, 10.08.1986. Leg. S.M. Slack-Smith, WAM Northern Territory Survey Aug. 1986, stn NTS/86/CP\#93 (WAM S9906, ex 42-95, 1 s.v.); Orontes Reef, Port Essington, $11^{\circ} 04$ 'S, $132^{\circ} 05^{\prime} \mathrm{E}, 11-14 \mathrm{~m}, 13.08 .1986$. Leg. S.M. Slack-Smith, stn SS/CP103 (WAM S79383, 1 s.v.); Oceanic Shoals, N.W. of Bathurst Isl., Parry Shoals, $11^{\circ} 12.5^{\prime} \mathrm{S}, 129^{\circ} 42.3^{\prime} \mathrm{E}, 16-18 \mathrm{~m}, 01.11 .2016$. Leg. H. Morrison (TP 4678, 1 p.v.).

Australia: Western Australia: Kimberley, S. end of Long Reef, $14^{\circ} 01^{\prime} \mathrm{S}, 125^{\circ} 44^{\prime} \mathrm{E}, 18.07 .1988$. Leg. F. Wells \& C. Bryce, WAM Kimberley Islands Survey 1988, Stn 650 (WAM S56960, 1 s.v.); Yankawingarri Island, $14^{\circ} 09^{\prime} \mathrm{S}, 125^{\circ} 39^{\prime} \mathrm{E}, 4-14 \mathrm{~m}, 19.08 .1991$. Leg. F. Wells \& C. Bryce, WAM Kimberley Islands \& Reefs Survey 1991, Stn 20 (WAM S56950, 1 s.v.); Cassini Island, $13^{\circ} 57^{\prime} 03.961^{\prime \prime S}, 125^{\circ} 38^{\prime} 54.238^{\prime \prime E}, 12$ m, 14.10.2010. Leg. C. Bryce \& C. Whisson, Woodside Kimberley Survey 2010, Stn 29/K10 (WAM, S58854, 1 p.v., 1 s.v.); Cassini Island, $13^{\circ} 56^{\prime} \mathrm{S}, 125^{\circ} 38^{\prime} \mathrm{E}$, 09.1998. Leg. H. Morrison \& C. Bryce, WAM Offshore Kimberley Survey 1998 (WAM S57116, 1 p.v.); Solem Islands, $14^{\circ} 11^{\prime} \mathrm{S}, 125^{\circ} 38^{\prime} \mathrm{E}, 4-18 \mathrm{~m}, 19.08 .1991$. Leg. F. Wells \& C. Bryce, WAM Kimberley Islands \& Reefs Survey 1991, Stn 22 (WAM S56951, 1 p.v.); Institut Islands, S.E. end of Condillac Island, $14^{\circ} 06^{\prime} \mathrm{S}$, $125^{\circ} 33^{\prime} \mathrm{E}, 15 \mathrm{~m}, 18.08 .1991$. Leg. F. Wells \& C. Bryce, WAM Kimberley Islands \& Reefs Survey 1991, Stn 18 (WAM S56949, 1 s.v.); East Montalivet Island, $14^{\circ} 16^{\prime} 38^{\prime \prime S}, 125^{\circ} 18^{\prime} 13^{\prime \prime E}$, 15.07.1988. Leg. F. Wells \& C. Bryce, WAM Kimberley Islands Survey 1988, Stn 50 (WAM S56598, 1 s.v.); North West Shelf, S.E. Mermaid Reef, $17^{\circ} 46^{\prime} 6.23^{\prime \prime S}, 120^{\circ} 43^{\prime} 9.12^{\prime \prime E}$ to 17²5'56.87"S, 12042'56.51"E, 97-109 m, 20.06.2007. Leg. C. Whisson \& O. Gomez, CSIRO RV 'Southern Surveyor' Cruise, Stn SS0507/097 (WAM S32858, 1 s.v.).

\section{DESCRIPTION}

Shell small to medium (H 30-46 mm), rather thin, equilateral to posteriorly expanded, ovoid and moderately elongate. Between 42-55 rounded radial ribs with numerous transverse ridges, more prominent anteriorly and posteriorly replaced by oblique scales. Interstices small and finely striated. Lunule small and elongated. External coloration white with very characteristic broken light brown lines and subsurface green-brown spots, located on the surface and nearly black on the posterior quarter. Interior reflects exterior colouration but is more prominent.

\section{DISTRIBUTION AND ECOLOGY}

The distribution of $A$. punctolineatum is now well established in the Central IWP (Vidal 1999; ter Poorten 2009), but until this study, it was not known from outside of QLD and NT in Australia (Vidal 1999). In WA, it has been recorded predominantly from nearshore communities in the Kimberley, consistent with other records for this species from shallow water, reefal environments (Figure 20C).

\section{REMARKS}

The largest specimen observed sofar is from QLD (NTM P.31486, H $46.2 \mathrm{~mm}$ ). Three possible syntypes of Cardium foveolatum G.B. Sowerby II, 1840 (NHMUK 1996514, the largest figured by Reeve 1845: pl. 18 fig. 87 based on a figure produced by G.B. Sowerby II; Fig. 1M) are fully in agreement with the present species. However, type figure, dimensions and Swan River type locality (G.B. Sowerby II 1840a: fig. 65; 1840b: 3; 1841: 111/511) are more in agreement with Cardium cygnorum Deshayes, 1855, as discussed by Wilson and Stevenson (1977). Hence, the true identity of Sowerby's $C$. foveolatum remains unresolved. Acrosterigma punctolineatum is sister to A. hobbsae Vidal, 1999, a species that is also known from QLD (NTM P.54171), as well as from the southern Indonesian islands of Sumbawa and Timor (TP 1337, 1338).

\section{Acrosterigma simplex (Spengler, 1799)}

Figures 12U-X, 20D

Cardium simplex Spengler, 1799: 31.

Cardium unicolor G.B. Sowerby II, 1834: fig. 29; 1840a: fig. 42; 1840b: 4, sp. 46.

Cardium nebulosum Reeve, 1845: sp. 99, pl. 19 fig. 99.

Laevicardium soyeri Fischer-Piette, 1977: 19-20, pl. 1 figs 4-7.

Acrosterigma unicolor (Sowerby, 1834) — Lamprell and Whitehead 1992: pl. 30 fig. 197.

Acrosterigma simplex (Spengler, 1799) — ter Poorten 2009: pl. 2 figs 1-3, pl. 5 fig. 3; Huber 2010: 297, fig.; ter Poorten 2011: pl. 1089 figs 6-7.

\section{MATERIAL EXAMINED}

Australia: Western Australia: Oceanic Shoals, N. side of Cartier Island, $12^{\circ} 31.5^{\prime} \mathrm{S}, 123^{\circ} 33.5^{\prime} \mathrm{E}$, in sand and bommies, 20-30 m, 09.1998. Leg. H. Morrison (TP 1339, 1 p.v.); Canning, Broome, Quong Dong, in muddy sand 
under stones, high intertidal, alive, 10.2009. Leg. W. Van Damme (TP 3988, 1 p.v.); Pilbara Offshore, Montebello Islands, Hermite Island, S. end of Stephenson Channel, 20²9'59"S, 115³1'50"E, 4 m, 15.08.1993. Leg. S.M. Slack-Smith, WAM Montebello Islands Survey 1993, Stn MBI/93/16 (WAM S78358, 1 p.v.).

\section{DESCRIPTION}

Shell medium (H 30-53 mm; only $4.2 \mathrm{~mm}$ in the present WAM material), rather solid, subequilateral, variably elongated, posteriorly slightly expanded and inflated. Margins rounded, central area of posterior margin in adults straight. Between 40-59 rather flattened radial ribs, rib sculpture anteriorly crenate laterally, posteriorly poorly ornamented. Interstices small, showing fine growth striae. Lunule large and asymmetric, larger on right valve. Periostracum relatively well developed on posterior slope. Exterior colour uniform light greyish-cream or yellowish, often darkened posteriorly, interior white, sometimes with splashes of pink or purple (ter Poorten 2009).

\section{DISTRIBUTION AND ECOLOGY}

This common shallow water species has a large but patchy distribution in the IWP (distribution map: Vidal 1999: fig. 18) and is known from neighboring countries and states including Indonesia (ter Poorten 2007), also West Timor, Roti Island (ZMA, Siboga Exped.) and QLD. The present samples are the first records of $A$. simplex from WA (Figure 20D).

\section{REMARKS}

The sole WAM record of this species is a juvenile specimen (Figures 12U-X, H $4.2 \mathrm{~mm}$ ). Acrosterigma simplex is distinguishable from other congeners by its rounded outline in the juvenile stage, its wide lunule (larger in r.v.), the lack of bright colours and by the ontogenetic disappearance of scales on the posterior quarter (Vidal 1999; ter Poorten 2009).

\section{Acrosterigma suduirauti Vidal \& ter Poorten, 2007}

Figures 120-R

Acrosterigma suduirauti Vidal \& ter Poorten, 2007: 72-74, figs 1-6, 11.

Acrosterigma suduirauti Vidal \& ter Poorten, 2007 ter Poorten 2011: pl. 1090, figs 2-6.

\section{MATERIAL EXAMINED}

Australia: Western Australia: Oceanic Shoals, Rowley Shoals, Imperieuse Reef L23 east, $17.5951^{\circ} \mathrm{S}$, $118.9817^{\circ} \mathrm{E}$ to $17.5891^{\circ} \mathrm{S}, 118.9799^{\circ} \mathrm{E}, 108-140 \mathrm{~m}$, 16.06.2007. Leg. C. Whisson, CSIRO RV 'Southern Surveyor' Cruise, Stn SS0507/062 (WAM S32883, 6 s.v.).

\section{DESCRIPTION}

Shell medium sized ( $\mathrm{H}$ up to $38 \mathrm{~mm}$ ), rather thin-shelled, slightly elongate-quadrate, inflated. Margins rounded, posterior margin nearly straight. Between 51-65 rounded radial ribs, becoming more oblique triangular posteriorly and separated by narrow interstices. Anterior ribs carrying commarginal scales covering complete rib width, median ribs carrying straight ridges on their posterior side and posterior ribs with well developed, distantly placed oblique ridges. Hinge typical for the genus, lunule small with raised margins. Exterior coloration whitish, yellowish, or orange with irregular red-brownish stains. Interior colours reflects exterior by transparency.

\section{DISTRIBUTION AND ECOLOGY}

Records of this species are previously thought to be restricted to the Philippines and Indonesia. The present record from WA not only implies a southward range extension but is the first record of this species in Australia. The sole WA record originates from the Rowley Shoals, situated on the outer edge of the continental shelf (Figure 1).

\section{REMARKS}

The Australian valves are in full agreement with the type material. It belongs to a group of deep water Acrosterigma species/specialists, although this notion is exclusively based on dead recordings of mostly single valves. Its closest congener is A. profundum Vidal, 1999, which also occurs in deep water but is mainly recorded from New Caledonia, Fiji and the Marshall Islands (colln MNHN, det. TP).

\section{Acrosterigma variegatum (G.B. Sowerby II, 1840)}

Figures 12S-T, 20E

Cardium variegatum G.B. Sowerby II, 1840a: fig. 57; 1840b: 4, sp. 45; 1841: 107.

Acrosterigma variegatum (G.B. Sowerby II, 1840) Huber 2010: 297, fig.; ter Poorten 2011: pl. 1089, figs 8-9.

Vasticardium swanae Maxwell, Congdon \& Rymer, 2016: 249, fig. 1, 2G, back cover (syn. nov.).

\section{MATERIAL EXAMINED}

Australia: Western Australia: Oceanic Shoals, Ashmore Reef, Lagoon middle entrance, $12^{\circ} 11^{\prime} 40.128^{\prime} \mathrm{S}, 123^{\circ} 03^{\prime} 00.533^{\prime} \mathrm{E}$, scuba, $7.4 \mathrm{~m}$, 01.10.2013. Leg. Kirkendale, L. \& Bryce, C., Woodside Kimberley Survey 2013, Stn 136/K13 (WAM S75358, 2 s.v.); Pilbara Offshore, Exmouth, dived, in sand, 20- 


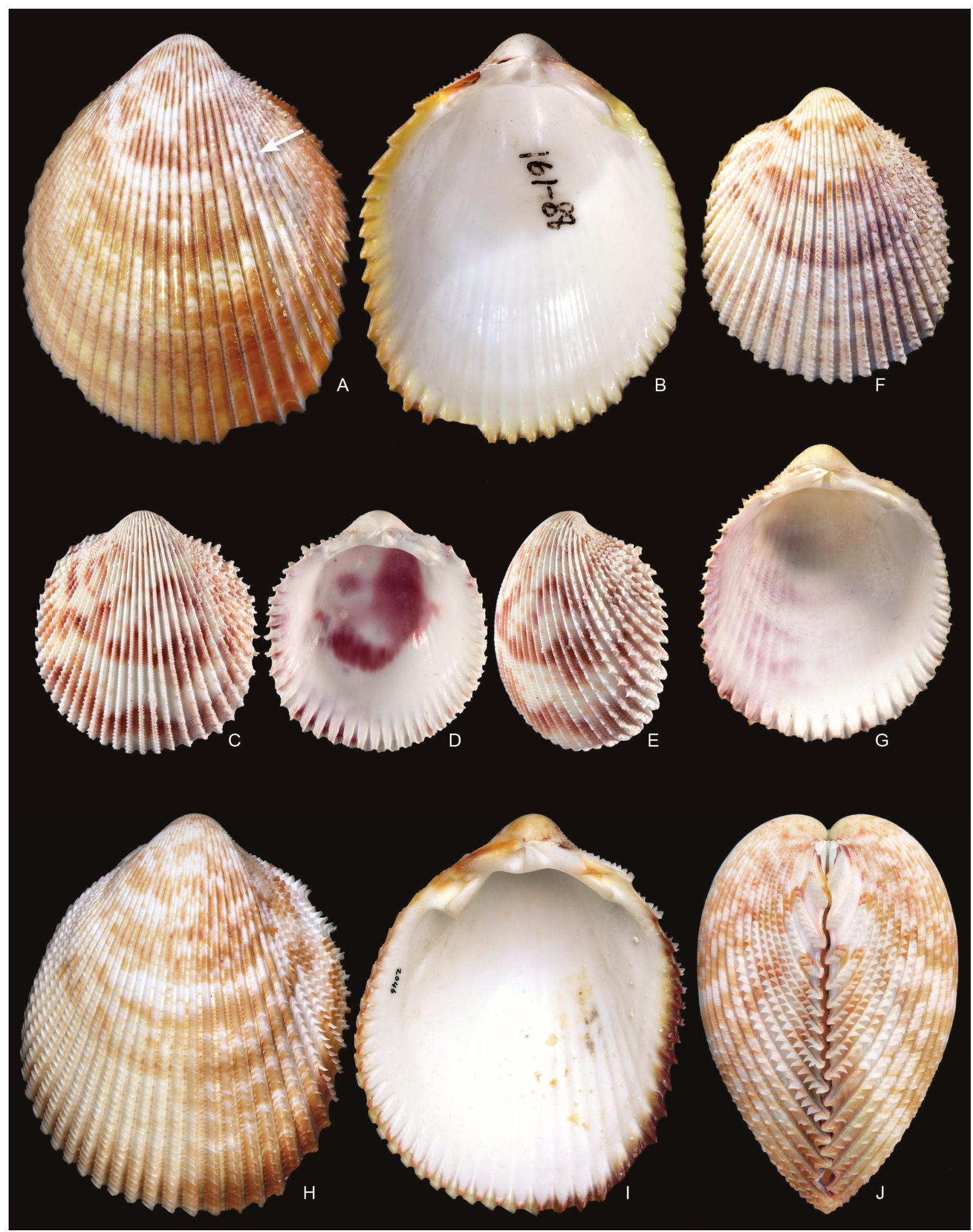

FIGURE $15 \quad A, B$, Vasticardium elongatum (Bruguière, 1789). Ashmore Reef, WA: WAM S56890, height 68.8 mm. A, exterior of I.V., B, interior of I.v.

C, D, E, F, G, Vasticardium mindanense (Reeve, 1844). C-E, Ashmore Reef, WA: NTM P.10066, height 29.3 $\mathrm{mm}$; C, exterior of I.V., D, interior of I.V., E, posterior slope of I.v.; F-G, Cagayan, Philippines: NHMUK 1978124, lectotype, height 40.4 mm. F, exterior of I.v., G, interior of I.v.

H, I, J, Vasticardium philippinense (Hedley, 1899). Broome, WA [probably originating from northern offshore reefs]: TP 2046, height $76.2 \mathrm{~mm}$. H, exterior of I.v., I, interior of r.v., J, posterior. 
25 m. Leg. Gary Wilson (TP 2264, 1 p.v.); Ningaloo,

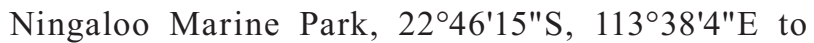
22॰46'14"S, 11338'3"E, $55 \mathrm{~m}, 08.02 .2008$. Leg. S.M. Slack-Smith, AIMS RV 'Solander' Cruise, Stn RVS4545-D116 (WAM S43505, 1 s.v.).

Literature records: Torres Strait, off Murray Isl., 954'34"S, 14402'37"E (Vidal, 1999: AMS C.30279).

\section{DESCRIPTION}

Shell rather large ( $\mathrm{H}$ up to $60 \mathrm{~mm}$ ), relatively solid, ovate and moderately inflated. Margins rounded, posterior margin nearly straight. Between 36-45 rounded radial ribs, becoming more pointed triangular on median-posterior part and separated by rather narrow interstices. Anterior ribs carrying close-set commarginal scales, median ribs hardly sculptured and posterior ribs flattened with erect, oblique ridges on their posterior side. Hinge typical for the genus, lunule small on left valve, much wider and deeply excavated on right valve. Exterior coloration whitish with irregular orange or redbrownish patches; interior white, with exterior colours more or less visible, margin yellowish to a variable degree or white.

\section{DISTRIBUTION AND ECOLOGY}

Australian distributional records are from northern QLD: Murray Island (E. of Torres Strait entrance), Port Douglas and Kurrimine (Vidal 1999; TP 4198). The two WAM records are from offshore coral reef settings (Ashmore Reef in the far north and Ningaloo) (Figure 20E). Acrosterigma variegatum is known from shallow water with sandy bottoms in coral reef environments and given the abundance of this habitat in WA, is expected to be widely distributed offshore.

\section{REMARKS}

The specimens from WA are both remarkably large (H 56.6; $60.0 \mathrm{~mm}$ ), one exceeding the maximum height (58.1 mm) as given by Vidal (1999) — apparently resulting from favourable environmental factors. However, other characters are entirely consistent with the known morphology of the species, including the typical nature of the lunule.

Recently Vasticardium swanae Maxwell, Congwon \& Rymer, 2016 has been introduced, apparently based on a single specimen from Bramble Reef, QLD. It differs from $A$. variegatum, by 'having a curved margin and shell which is distinctly more ovate' and by lacking the tinged yellow internal margin (Maxwell et al. 2016: 250). However, the shell shape of $A$. variegatum agrees with $V$. swanae. This is apparent when one compares the syntypes of the former species (NHMUK 20140803, Hylleberg 2004: 870, unnumbered figures) with a figure of the holotype of $V$. swanae placed on the back cover of the journal in which the species has been described (not photographed under an angle, unlike the figure accompanying the description; high resolution version kindly made available by the editor of the journal, David Berschauer). The yellow internal margin is variably developed in $A$. variegatum and therefore unreliable for taxonomic separation; it is hardly present in the syntypes. As the rib number ('40-50', not given for the holotype of $V$. swanae, c. 42 ribs can be counted), rib sculpture, rib shape and external coloration all match, there is no reason to separate the QLD population and $V$. swanae is herein regarded a synonym of $A$. variegatum.

\section{Genus Vasticardium Iredale, 1927}

Vasticardium Iredale, 1927: 75-76. Type species by original designation: Cochlea nebulosa Martyn, 1784 [= Cardium elongatum Bruguière, 1789]; Recent (type locality not mentioned).

Regozara Iredale, 1936: 275. Type species by original designation: Regozara olivifer Iredale, 1936 [= Cardium vertebratum Jonas, 1844]; Recent, Sydney Harbour, New South Wales, Australia.

\section{Vasticardium elongatum (Bruguière, 1789)}

Figures 15A-B

Cochlea nebulosa Martyn, 1784: 50, pl. 46 fig. 1 (rejected work).

Cardium elongatum Bruguière, 1789: 228-229.

Vasticardium elongatum (Bruguière, 1789) — Huber 2010: 293, fig. [pars]; ter Poorten 2011: pl. 1092 figs 4-6.

Not: Acrosterigma elongatum (Bruguière, 1789) Wilson and Stevenson 1977: 78-80, pl. 5 figs 1-4 [= paratype of Acrosterigma wilsoni Voskuil \& Onverwagt, 1991, WAM S65194).

Not: Acrosterigma elongata (Bruguière, 1789) Lamprell and Whitehead 1992: pl. 29 fig. 186 [= Vasticardium coralense (Vidal, 1993)].

\section{MATERIAL EXAMINED}

Australia: Western Australia: Oceanic Shoals, Ashmore Reef, Lagoon middle entrance, $12^{\circ} 11^{\prime} 40.128^{\prime \prime S}$, $123^{\circ} 03^{\prime} 00.533 " \mathrm{E}$, scuba, $7.4 \mathrm{~m}, 01.10 .2013$. Leg. L. Kirkendale \& C. Bryce, Woodside Kimberley Survey 2013, Stn 136/K13 (WAM S75817, 1 s.v.); West Island, 
$12^{\circ} 11^{\prime} \mathrm{S}, 122^{\circ} 58^{\prime} \mathrm{E}, 16.10 .1978$. Leg. B.R. Wilson, Bogorov 1978 Exped. (WAM S56890, 1 p.v. of which 1 valve fragm.); Ashmore Reef, 25.09.1988/1989. Leg. M. Claydon (TP 4827, 1 p.v.).

\section{DESCRIPTION}

Shell large (H 100-135 mm), solid, almost equilateral, elongate and inflated. Margins rounded, posterior margin often almost straight. Anterior margin crenulate, ventral and posterior margin digitate. Between 35-44 radial ribs, flat-topped, square-sided on anterior and median part and low rounded with radial cord on top on posterior part. Ribs marginally serrated on anterior and median part, posterior 3-5 ribs with small oblique scales. Interstices narrow and smooth. Lunule well defined and weakly raised dorsally. Exterior cream with various shades of brown-yellow to purple, especially on postero-ventral slope; internally white with yellowish brown anterior margin and purple or pink ventral and posterior margin.

\section{DISTRIBUTION AND ECOLOGY}

In WA, true $V$. elongatum appears confined to the northern offshore reefs, based on two shallow water records from Ashmore Reef. It is found in the Central IWP in the Philippines and central Indonesia.

\section{REMARKS}

Vidal (1993) established six geographic subspecies of the polytypic Cardium elongatum Bruguière, 1789, drawing on the observation that many transitional specimens occur in each geographic region and following the 75 per cent rule of Mayr et al. (1953). Initially these were assigned to Acrosterigma; later Vidal (1996) transferred them to Vasticardium. Two of these taxa occur in WA, Vasticardium elongatum (Bruguière, 1789) and $V$. wilsoni (Voskuil \& Onverwagt, 1991); the former is distributed in the hyperdiverse Philippines-Indonesia region, the latter is restricted to northern Australia. A long-term study of this species complex by the first author made clear that all these taxa show allopatric distribution patterns, that the number of transitional specimens is very limited and that distribution boundaries coincide with geographic barriers in dispersal. Co-occurrences are lacking, even in the Indonesia-Philippines region. Altogether, these criteria are strongly indicative of allopatric speciation, hence all taxa in the elongatum complex are herein given specific status.

The samples attributed by Wilson and Stevenson (1977) to this species invariably proved to represent $V$. wilsoni. In contrast to the strictly inshore and continental shelf distribution of this species, the oceanic records of $V$. elongatum are proof of connectivity with the Central IWP region. The three WA samples represent the first Australian records of $V$. elongatum.
Two of these (WAM S56890, Figures 15A-B, arrow; TP 4827) are tuberculated forms (small rounded tubercles present on the posterior slope).

\section{Vasticardium mindanense (Reeve, 1844)}

Figures $15 \mathrm{C}-\mathrm{G}$

Cardium mindanense Reeve, 1844: sp. 19, pl. 4 fig. 19.

Vasticardium lomboke Vidal, 2003: 58, figs 4-5, 8 (syn. nov.).

\section{MATERIAL EXAMINED}

Australia: Western Australia: Oceanic Shoals, Approx. mid-northern coast of Ashmore Reef, $12^{\circ} 13.47^{\prime} \mathrm{S}, 122^{\circ} 57.77^{\prime} \mathrm{E}, 24 \mathrm{~m}$, on the surface of silty sand at the base of outer reef slope, 06.09.1996. Leg. R.C. Willan (NTM P.10066, 1 s.v.).

\section{DESCRIPTION}

Shell medium sized (H 40-50 mm), solid, almost equilateral, slightly elongate and inflated. Margins rounded, posterior margin straight. Anterior margin crenulate, ventral and posterior margin digitate. Between 33-38 prominent radial ribs, oblique-squaresided on anterior and median part and triangular to trapezoidal on posterior part. Ribs carrying crescentshape rugae on anterior part, becoming V-shaped on median part and oblique scales along with fine ridges on rib sides on posterior part (Figure 15E). Interstices about one third of the rib width. Lunule narrow, slightly wider in right valve. Exterior white with purple-brown more or less commarginally arranged maculations; internally white with umbonal cavity sometimes purple.

\section{DISTRIBUTION AND ECOLOGY}

Only one sample was recovered from WA (the first Australian record) and it was collected from Ashmore Reef, one of the emergent reefs of the northernmost Sahul Shelf (Figures 15C-E). It is widely distributed in the Central IWP, mostly found in shallow water and nearly always taken from death assemblages, suggesting that its preferred habitat has not been sampled.

\section{REMARKS}

Vasticardium mindanense is a typical component of the Central IWP molluscan fauna that has colonised the northern offshore reefs, with larval dispersal enhanced by the main oceanic current system, the ITF (Willan 2005; Wilson 2013). The lectotype of Cardium mindanense (NHMUK 1978124, Figures 15F-G) has been compared with the holotype of Vasticardium lomboke Vidal, 2003 (MNHN-IM-2000-3998), 
originating from the N.W. coast of Lombok, Indonesia. Although the shell is worn, polished and juvenile $(\mathrm{H}$ $29.3 \mathrm{~mm}$ ), close examination leads to the conclusion that both are identical and that $V$. lomboke should be regarded as a junior synonym. The $V$. mindanense group has recently been revised (Hylleberg, 2017).

\section{Vasticardium philippinense (Hedley, 1899)}

Figures $15 \mathrm{H}-\mathrm{J}, 20 \mathrm{~F}$

Cardium angulatum Lamarck: Reeve, 1845: sp. 70, pl. 14 fig. 70 (non Cardium angulatum Lamarck, 1819).

Cardium philippinense Deshayes: Hedley, 1899: 503504.

Cardium (Trachycardium) pseudoangulatum Bülow, 1905: 79-80, pl. 1 fig. 3.

Acrosterigma mendanaense (Sowerby, 1896) Lamprell and Whitehead 1992: pl. 29 fig. 188 [Not Vasticardium mendanaense (G.B. Sowerby III, 1897)].

'Acrosterigma obesa (Broderip \& Sowerby, 1833)' [nomen nudum] — Lamprell and Healy 1998: 256.

Vasticardium philippinense (Hedley, 1899) - ter Poorten 2009: pl. 3 figs 4-5; Huber 2010: 296, fig.; ter Poorten 2011: pl. 1093 figs 4-5.

\section{MATERIAL EXAMINED}

Australia: Northern Territory: Oceanic Shoals, $155 \mathrm{~km}$ due N. of central northern coast of Melville Island, Lynedoch Bank, $10^{\circ} 1^{\prime} \mathrm{S}, 130^{\circ} 48^{\prime} \mathrm{E}, 03.12 .2014$. Leg. H. Morrison (NTM P.54750, 1 p.v.); 230 km N.W. of northern coast of Bathurst Island, central Arafura Sea, Flinders Shoals, 9०43'11"S, 129 48'0"E, 13-15 m. 03.11.2015. Leg. H. Morrison (NTM P.55751, 2 p.v.).

Australia: Western Australia: Oceanic Shoals, 240 $\mathrm{km} \mathrm{N.W.} \mathrm{of} \mathrm{northern} \mathrm{coast} \mathrm{of} \mathrm{Bathurst} \mathrm{Island,} \mathrm{central}$ Arafura Sea, Martin Shoal, 9³6.64'S, 128 $52.6^{\prime} \mathrm{E}, 16-20$ m. 03.11.2015. Leg. H. Morrison (NTM P.55827, 1 p.v., A; NTM P.55829, 1 p.v.); $260 \mathrm{~km} \mathrm{N.W.} \mathrm{of} \mathrm{northern} \mathrm{coast}$ of Bathurst Island, central Arafura Sea, Loxton Shoal, 9³6'18"S, 12843'12"E, 17-18 m. 03.11.2015. Leg. H. Morrison (NTM P.56004, 4 p.v., A); Vulcan Shoal, 1247'57.481"S, 124¹6'00.205"E, 19 m, 06.10.2013. Leg. L. Kirkendale \& C. Bryce, Woodside Kimberley Survey 2013, Stn 146/K13 (WAM S91778, 1 s.v.); Heywood Shoal, $12^{\circ} 26^{\prime} 50.675^{\prime \prime S}, 124^{\circ} 01^{\prime} 56.785^{\prime \prime E}, 24 \mathrm{~m}$, 07.10.2013. Leg. L. Kirkendale \& C. Bryce, Woodside Kimberley Survey 2013, Stn 148/K13 (WAM S91794, 2

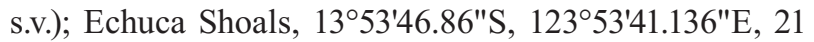
$\mathrm{m}$, isolated outcrop, 18.10.2012. Leg. C. Bryce, Woodside Kimberley Survey 2012, Stn 107/K12 (WAM S85182, 1 p.v.); Echuca Shoals, 1354'02.484"S, $123^{\circ} 53^{\prime} 36.412^{\prime} \mathrm{E}, 19 \mathrm{~m}$, isolated outcrop, 18.10.2012.
Leg. C. Bryce, Woodside Kimberley Survey 2012, Stn 108/K12 (WAM S85112, 1 p.v., 1 s.v.); Cartier Island, $12^{\circ} 32^{\prime} \mathrm{S}, 123^{\circ} 33^{\prime} \mathrm{E}, 30 \mathrm{~m}$, sand at base of bommie, 14.09.1998. Leg. C. Bryce, WAM Offshore Kimberley Survey 1998 (WAM S76772, 1 p.v., A); W. end, $12^{\circ} 32.200^{\prime} \mathrm{S}, 123^{\circ} 31.9^{\prime} \mathrm{E}, 17-18 \mathrm{~m}$, on patch of clean sand, 04.05.1992. Leg. R.C. Willan (NTM P.29354, 1 p.v.); Browse Island, $14^{\circ} 06^{\prime} 45.289^{\prime S}, 123^{\circ} 32^{\prime} 04.475^{\prime E}$, $13 \mathrm{~m}$, fore reef (outer), 16.10.2012. Leg. C. Bryce, Woodside Kimberley Survey 2012, Stn 102/K12 (WAM S85070, 1 p.v.); Hibernia Reef, N.W. corner, $11^{\circ} 55^{\prime} \mathrm{S}$, $123^{\circ} 28^{\prime} \mathrm{E}, 24 \mathrm{~m}, 19.09 .1994$. Leg. C. Bryce \& H. Morrison, Bryce \& Morrison Kimberley Survey 1994 (WAM S57109, 2 p.v.); S. side, $11^{\circ} 55^{\prime} \mathrm{S}, 123^{\circ} 28^{\prime} \mathrm{E}, 3 \mathrm{~m}$, 18.09.1996. Leg. H. Morrison \& C. Bryce, WAM Offshore Kimberley Survey 1996 (WAM S57110, 1 p.v.); S. side, $11^{\circ} 55^{\prime} \mathrm{S}, 123^{\circ} 28^{\prime} \mathrm{E}, 3 \mathrm{~m}$, sand and coral, 19.09.1996. Leg. H. Morrison \& C. Bryce, WAM Offshore Kimberley

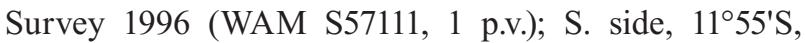
$123^{\circ} 28^{\prime} \mathrm{E}, 2$ m, 19.09.1996. Leg. H. Morrison \& C. Bryce, WAM Offshore Kimberley Survey 1996 (WAM S57112, 1 p.v.); S.E. corner, $11^{\circ} 58^{\prime} 33.781^{\prime \prime S}, 123^{\circ} 23^{\prime} 22.817^{\prime \prime E}, 17 \mathrm{~m}$, fore reef (slope), 05.10.2013. Leg. L. Kirkendale \& C. Bryce, Woodside Kimberley Survey 2013, Stn 145/K13 (WAM S91819, 1 p.v., 1 s.v.); N.E. side, $11^{\circ} 57^{\prime} 42.012^{\prime \prime S}$, $123^{\circ} 22^{\prime} 42.881^{\prime} \mathrm{E}, 13 \mathrm{~m}$, fore reef (outer), 04.10.2013. Leg. L. Kirkendale \& C. Bryce, Woodside Kimberley Survey 2013, Stn 143/K13 (WAM S75883, 1 s.v.); N. side, reef slope, immediately outside entrance to lagoon, $11^{\circ} 57.8^{\prime} \mathrm{S}$, $123^{\circ} 22.3^{\prime} \mathrm{E}, 8^{8}-12 \mathrm{~m}$, in rubble patches on the floor of surge channels, 10.05.1992. Leg. R.C. Willan (NTM P.13186, 1 p.v., 1 s.v.); S.E. side, $11^{\circ} 59.02^{\prime S}, 123^{\circ} 22.09^{\prime} \mathrm{E}$, $35 \mathrm{~m}$, on surface coral sand, on steep outer reef slope, 13.05.1992. Leg. R.C. Willan (NTM P.35129, 2 p.v.); N. side, base of outer reef slope, just west of 'false entrance', $11^{\circ} 58.01^{\prime} \mathrm{S}, 123^{\circ} 21.02^{\prime} \mathrm{E}, 27 \mathrm{~m}$, on surface of fine coral substrate, 'Halimeda meadow', 12.05.1992. Leg. R.C.

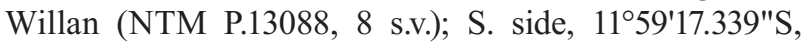
$123^{\circ} 20^{\prime} 09.073$ "E, $24 \mathrm{~m}$, fore reef (slope), 04.10.2013. Leg. L. Kirkendale \& C. Bryce, Woodside Kimberley Survey 2013, Stn 142/K13 (WAM S75895, 5 p.v.); W. point, $11^{\circ} 58^{\prime} 26.544^{\prime \prime S}, 123^{\circ} 19^{\prime} 19.497^{\prime} \mathrm{E}, 15 \mathrm{~m}$, fore reef (slope), 05.10.2013. Leg. L. Kirkendale \& C. Bryce, Woodside Kimberley Survey 2013, Stn 144/K13 (WAM S75891, 1 p.v.); $11^{\circ} 58^{\prime} \mathrm{S}, 123^{\circ} 19^{\prime} \mathrm{E}, 09.1998$. Leg. H. Morrison \& C. Bryce, WAM Offshore Kimberley Survey 1998 (WAM S57113, 6 p.v.); Ashmore Reef, N.E. corner, $12^{\circ} 14^{\prime} 14.208^{\prime \prime S}, 123^{\circ} 09^{\prime} 36.151^{\prime \prime E}, 15 \mathrm{~m}$, fore reef (outer), 27.09.2013. Leg. L. Kirkendale \& C. Bryce, Woodside Kimberley Survey 2013, Stn 127/K13 (WAM S75140, 3 p.v.); S. side, $12^{\circ} 17^{\prime} 36.6^{\prime \prime S}, 123^{\circ} 07^{\prime} 25.441^{\prime \prime E}, 12 \mathrm{~m}$, fore reef (outer), 28.09.2013. Leg. L. Kirkendale \& C. Bryce, Woodside Kimberley Survey 2013, Stn 128/K13 (WAM S75818, 1 s.v.); Middle Passage, W., $12^{\circ} 14^{\prime}$ S, $123^{\circ} 05^{\prime} \mathrm{E}$, 8-20 m, 17.09.1986. Leg. F.E. Wells \& C.W. Bryce, WAM Ashmore Reef \& Cartier Island Survey 1986, Stn 15 (WAM S78227, ex 43-95, 1 p.v.); approx. mid-northern coast, $12^{\circ} 17^{\prime} \mathrm{S}, 123^{\circ} 02^{\prime} \mathrm{E}, 12 \mathrm{~m}$, amongst coral rubble and coarse sand, outer reef slope, 09.09.1996. Leg. R.C. Willan (NTM P.9204, 2 s.v.); N. Ashmore Reef, 12¹1'37.608"S, 
$123^{\circ} 01^{\prime} 42.228^{\prime \prime E}, 12 \mathrm{~m}$, fore reef (slope), 26.09.2013. Leg. L. Kirkendale \& C. Bryce, Woodside Kimberley Survey 2013, Stn 125/K13 (WAM S75091, 1 s.v.); N.W. coast, W. side of entrance into W. lagoon, $12^{\circ} 13^{\prime} \mathrm{S}, 123^{\circ} 0^{\prime} \mathrm{E}, 1 \mathrm{~m}$, amongst coral rubble, rubble bank at reef crest, 03.09.1996. Leg. R.C. Willan \& K.A. Glenn (NTM P.2155, 1 s.v.); western anchorage, $12^{\circ} 11^{\prime} \mathrm{S}, 122^{\circ} 58^{\prime} \mathrm{E}, 17.10 .1978$. Leg. B.R. Wilson, Bogarov 1978 (WAM S56849, 1 p.v.); N.E. corner, $12^{\circ} 10^{\prime} \mathrm{S}, 122^{\circ} 58^{\prime} \mathrm{E}, 6-8 \mathrm{~m}, 14.09 .1986$. Leg. F. Wells \& C. Bryce, WAM Ashmore Reef \& Cartier Island Survey 1986, Stn 8 (WAM S56846, 1 p.v.); Ashmore Reef, S.E. corner, $12^{\circ} 10^{\prime} \mathrm{S}, 122^{\circ} 58^{\prime} \mathrm{E}, 12 \mathrm{~m}, 15.09 .1986$. Leg. F. Wells \& C. Bryce, WAM Ashmore Reef \& Cartier Island Survey 1986, Stn 10 (WAM S56847, 3 s.v.); reef flat N. of West Island, $12^{\circ} 14^{\prime} \mathrm{S}, 122^{\circ} 58^{\prime} \mathrm{E}$, reef flat, 17.09.1986. Leg. F. Wells \& C. Bryce, WAM Ashmore Reef \& Cartier Island Survey 1986, Stn 16 (WAM S56848, 1 s.v.); N.E. corner, $12^{\circ} 10^{\prime} \mathrm{S}, 122^{\circ} 58^{\prime} \mathrm{E}$, outer reef edge, 17.09.1994. Leg. C. Bryce \& H. Morrison, Bryce \& Morrison Kimberley Survey 1994 (WAM S56966, 1 s.v.); N.E. corner, $12^{\circ} 10^{\prime} \mathrm{S}, 122^{\circ} 58^{\prime} \mathrm{E}, 15-18 \mathrm{~m}, 17.09 .1994$. Leg. C. Bryce \& H. Morrison, Bryce \& Morrison Kimberley Survey 1994 (WAM S56967, 1 p.v.); Ashmore Reef, approx. mid-northern coast, $12^{\circ} 13.47^{\prime} \mathrm{S}, 122^{\circ} 57.77^{\prime} \mathrm{E}, 24$ $\mathrm{m}$, on the surface of silty sand, at the base of outer reef slope, 06.09.1996. Leg. R.C. Willan (NTM P.2056, 1 s.v.); approx. mid-northern coast, $12^{\circ} 13.47^{\prime} \mathrm{S}, 122^{\circ} 57.77^{\prime} \mathrm{E}, 22$ $\mathrm{m}$, on the surface of silty sand, at the base of outer reef slope, 10.09.1996. Leg. R.C. Willan (NTM P.2008, 2 s.v.); Seringapatam Reef, lagoon, $13^{\circ} 38^{\prime} \mathrm{S}, 122^{\circ} 05^{\prime} \mathrm{E}, 09.1994$. Leg. C. Bryce, Bryce \& Morrison Kimberley Survey 1994 (WAM S40371, 1 p.v., A); lagoon, $13^{\circ} 38^{\prime} \mathrm{S}, 122^{\circ} 05^{\prime} \mathrm{E}, 8 \mathrm{~m}$, 16.09.1996. Leg. C. Bryce \& H. Morrison, WAM Offshore Kimberley Survey 1998 (WAM S39957, 2 p.v.); Seringapatam Reef, no further data, $13^{\circ} 40^{\prime} \mathrm{S}, 122^{\circ} 05^{\prime} \mathrm{E}$, 09.1998. Leg. C. Bryce \& H. Morrison, WAM Offshore Kimberley Survey 1998 (WAM S39956, 1 p.v.); S. Scott Reef, 0.5 km S.W. Sandy Island, $14^{\circ} 04^{\prime} 28^{\prime \prime S}, 121^{\circ} 56^{\prime} 16^{\prime \prime E}$, 8-18 m, 07.09.1984. Leg. F. Wells \& C. Bryce, WAM Scott \& Seringapatam Reefs Survey 1984, Stn 1 (WAM S39921, 1 p.v.); N. Scott Reef, E. side, $13^{\circ} 55^{\prime} 48^{\prime \prime S}$, 12155'22"E, 9-18 m, 13.09.1984. Leg. F. Wells \& C. Bryce, WAM Scott \& Seringapatam Reefs Survey 1984, Stn 15 (WAM S39922, 2 fragm. from 1 p.v.; WAM S40375 1 p.v., A); S. Scott Reef, S. Sandy Island, 1359'S, 1214'' E, 15-20 m, 09.09.1984. Leg. F. Wells \& C. Bryce, WAM Scott \& Seringapatam Reefs Survey 1984 (WAM S39925, 2 p.v.); S. Scott Reef, S. Sandy Island, 1359'S, 1214' E, 18-20 m, 09.09.1984. Leg. T. Knight, WAM Scott \& Seringapatam Reefs Survey 1984 (WAM S39923, 1 p.v); S. Scott Reef, S. end, 1359'S, 12146'E, 09.1994. Leg. C. Bryce, Bryce \& Morrison Kimberley Survey 1994 (WAM S40374, 1 p.v., A); S. Scott Reef, Sandy Island, $13^{\circ} 59^{\prime}$ S, $121^{\circ} 46^{\prime} \mathrm{E}, 10.10 .2002$. Leg. K. Pendoley (WAM S39962 1 s.v.); S. Scott Reef, West horn, outer slope, $14^{\circ} 07.493$ 'S, $121^{\circ} 42.919^{\prime} \mathrm{E}, 4.5-20 \mathrm{~m}, 19.09 .2006$. Leg. C.W. Bryce \& C.S. Whisson, WAM NWA Shelf Atolls Survey September 2006, Stn 20 (WAM S31125, 1 p.v.); Scott Reef, coral and rock gutters, amongst rubble, 10-20 m, 10.1984 (TP 4447, 1 p.v.); Rowley Shoals, Mermaid
Reef, inner lagoon, E. side, $17^{\circ} 05.374^{\prime} \mathrm{S}, 119^{\circ} 38.948^{\prime} \mathrm{E}$, 3.5-10.5 m, coral bombie and surrounds, 12.09.2006. Leg. C.W. Bryce \& C.S. Whisson, WAM NWA Shelf Atolls Survey September 2006, Stn 1 (WAM S31002, 1 p.v.); Lagoon, Entrance Channel, $17^{\circ} 03.726$ 'S, $119^{\circ} 38.385^{\prime} \mathrm{E}$, 0-18 m, 15.09.2006. Leg. C.W. Bryce \& C.S. Whisson, WAM NWA Shelf Atolls Survey September 2006, Stn 10 (WAM S31068, 1 p.v.); Clerke Reef, $17^{\circ} 19^{\prime} 01.095^{\prime \prime S}$, $119^{\circ} 23^{\prime} 01.613^{\prime \prime E}, 12-18$ m, 10.10.2014. Leg. C. Bryce, Woodside Kimberley Survey 2014, Stn 170/K14 (WAM S95436, 1 p.v.); $17^{\circ} 16^{\prime} 47.673^{\prime \prime S}, 119^{\circ} 22^{\prime} 35.878^{\prime \prime E}, 15 \mathrm{~m}$, 04.10.2014. Leg. C. Bryce, Woodside Kimberley Survey 2014, Stn 154/K14 (WAM S95436, 3 s.v.); N.E. corner, N. of N. passage, outer reef slope, $17^{\circ} 15^{\prime} 42^{\prime \prime S}, 119^{\circ} 22^{\prime} 06^{\prime \prime E}$, 10-20 m, 22.07.1982. Leg. WA Museum Party, WAM Rowley Shoals Exped. 1982, Stn 14 (WAM S39924, 2 fragm. from 1 p.v.); N.E. end, reef slope, 17²1'17"S, $119^{\circ} 21^{\prime} 46^{\prime \prime E}, 20$ m, 07.1982. Leg. WA Museum Party, WAM Rowley Shoals Exped. 1982, Stn 6 (WAM S39919, 1 p.v.); 17¹6'26"S, 119²1'34"E, 0 m, 22.07.1982. Leg. WA Museum Party, WAM Rowley Shoals Exped. 1982, Stn 15 (WAM S39920, 1 s.v.); N. end, outer reef slope, $17^{\circ} 14^{\prime} 50^{\prime \prime S}, 19^{\circ} 20^{\prime} 18^{\prime \prime E}, 10-20$ m, 24.07.1982. Leg. WA Museum Party, WAM Rowley Shoals Exped. 1982, Stn 8 (WAM S39918, 1 fragm.); E. reef S. of channels, $17^{\circ} 18^{\prime} \mathrm{S}$, $119^{\circ} 20^{\prime} E$, 07.1982. Leg. WA Museum Party, WAM Rowley Shoals Exped. 1982 (WAM S39917, 1 p.v.); Imperieuse Reef, $17^{\circ} 17^{\prime} 34.729^{\prime \prime} \mathrm{S}, 119^{\circ} 22^{\prime} 41.481^{\prime \prime E}, 12 \mathrm{~m}$, 04.10.2014. Leg. C. Bryce, Woodside Kimberley Survey 2014, Stn 156/K14 (WAM S68126, 1 p.v.); 17³2'09.494"S, 118 58'23.705"E, 15 m, 06.10.2014. Leg. C. Bryce, Woodside Kimberley Survey 2014, Stn 158/K14 (WAM S68174, 1 p.v.).

Literature records: Vidal (1997): Ashmore Reef (WAM S78227, ex 43-95, 1 p.v.); Willan (2005): Ashmore Reef, Cartier Reef and Hiberna Reef.

\section{DESCRIPTION}

Shell large (H 80-116 mm), solid, elongate, subequilateral to clearly inequilateral in the adult with slight expansion of posterior slope. Anterior and ventral margin rounded, occasionally straight in fully adult specimens. Between 36-42 oblique squarish to triangular radial ribs, with top or posterior oblique side ridges and erect lamellae on postero-dorsal slope. Hinge with hooked base of the anterior lateral on both valves, hinge plate broad. Lunule large and well delimited with raised margins. External colour white or tan with brownish-purple irregular splashes, more pronounced posteriorly and with dark brown stains towards posterior margin; internally white to yellow with margin bright purple and hinge plate bordering lunule orange-yellow.

\section{DISTRIBUTION AND ECOLOGY}

In WA, $V$. philippinense is very common but strictly confined to the oceanic emergent reefs of the shelf margin: out of 55 records, not a single one is known from the continental coast (Figure 20F). This offshore occurrence often coincides with a wide IWP 


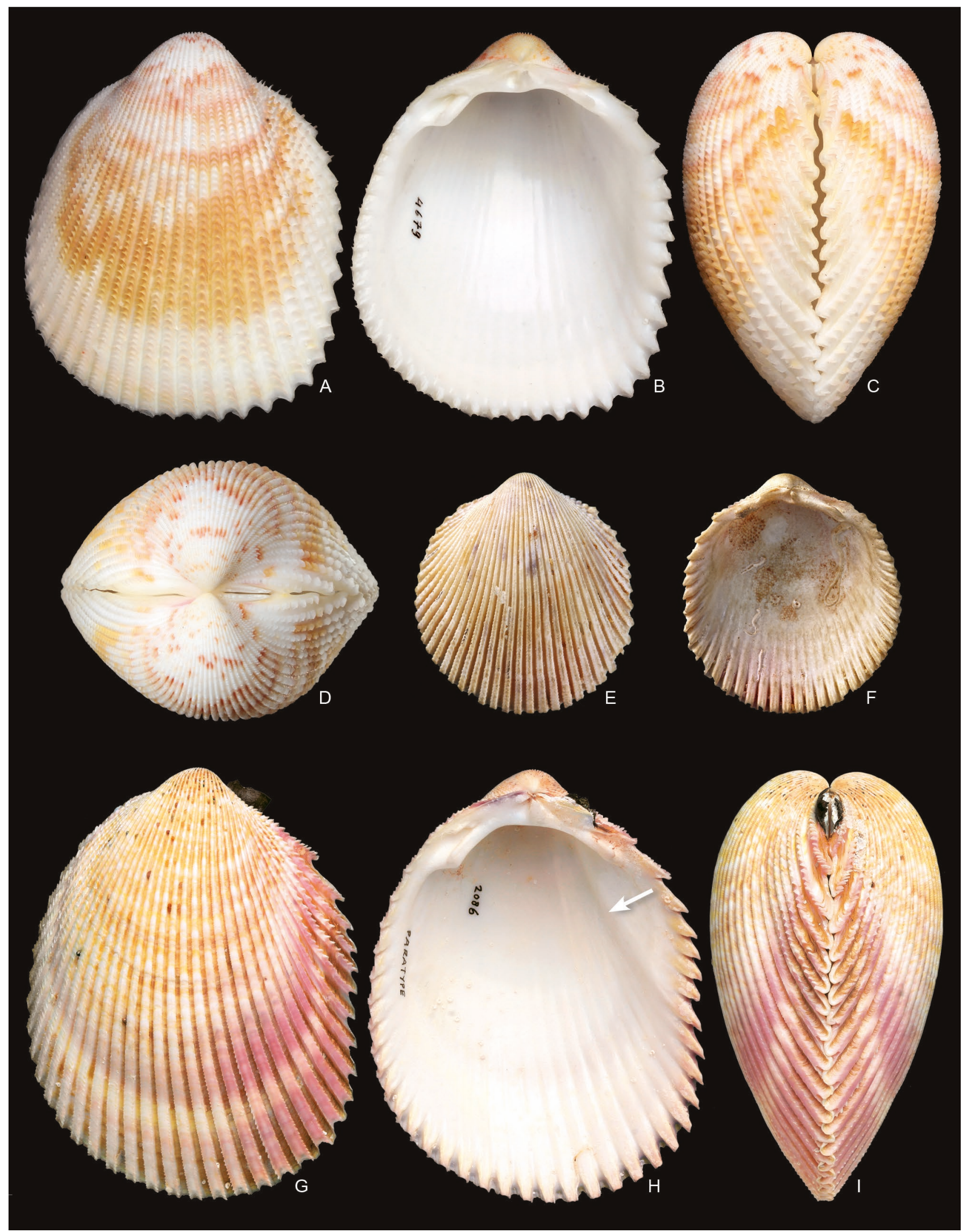

FIGURE 16 A, B, C, D, Vasticardium sewelli (Prashad, 1932). Martin Shoal, WA: TP 4679, height 64.4 mm. A, exterior of I.v., B, interior of r.v., C, posterior, D, dorsal.

E, F, Vasticardium serricostatum (Melvill \& Standen, 1899). Torres Straits, QLD: NHMUK 1899.2.23.10, syntype, height $21.5 \mathrm{~mm}$. E, exterior of I.V., F, interior of I.V.

G, H, I, Vasticardium wilsoni (Voskuil \& Onverwagt, 1991). Dampier, WA: TP 2086, paratype, height 73.0 $\mathrm{mm}$. G, exterior of I.V., H, interior of r.v., I, posterior. 
distribution. It is restricted to oligotrophic conditions and lives in shallow water in exposed coral reef environments, predominantly on clean sandy bottoms (ter Poorten 2009).

\section{REMARKS}

Material under the name 'Acrosterigma orbita (Broderip \& Sowerby, 1833)' recorded from Rowley Shoals and Scott Reef (Wells and Slack-Smith 1986; Bryce and Whisson 2009) and from Ashmore Reef and Cartier Island (Wells 1993) refers to this species. True Vasticardium orbita is restricted to the southwest Pacific. While true $V$. mendanaense (name wrongly employed by Lamprell and Whitehead 1992, Willan et al. 2015) is a narrow range endemic occurring off the Marquesas Islands (Vidal 1997). The ecological preferences of $V$. philippinense well describe the ecological category described by Wilson (2013: 272-273): 'The reef species inhabiting the shelf-edge and outer shelf reefs of the Oceanic Shoals Bioregion are predominantly widespread IWP planktotrophic, oceanic species, capable of long-distance dispersal and colonization of remote localities'. The biggest WA specimen has a height of $112 \mathrm{~mm}$ (WAM S40371), which nearly equals the largest size known.

\section{Vasticardium sewelli (Prashad, 1932)}

\section{Figures $16 \mathrm{~A}-\mathrm{D}$}

Cardium sewelli Prashad, 1932: 268, pl. 6 figs 25-26.

Cardium (Trachycardium) laddi Abrard, 1946: 33-34, pl. 3 figs $1-2$.

Vasticardium sewelli (Prashad, 1932) — ter Poorten 2009: pl. 4 figs 3-4; ter Poorten 2011: pl. 1093 fig. 1.

"Vasticardium" sewelli (B. Prashad, 1932) — Huber 2010: 296, fig.

\section{MATERIAL EXAMINED}

Australia: Northern Territory: Oceanic Shoals, N.W. of Bathurst Isl., Parry Shoals, $11^{\circ} 12.5^{\prime} \mathrm{S}, 129^{\circ} 42.3^{\prime} \mathrm{E}$, 16-18 m, in sand, rubble and coral, 04.11.2015. Leg. H. Morrison (TP 4731, 1 p.v.).

Australia: Western Australia: Oceanic Shoals, Martin Shoal, 9 $9^{\circ} 36.64^{\prime} \mathrm{S}, 1^{\circ} 8^{\circ} 52.6^{\prime} \mathrm{E}, 16-50 \mathrm{~m}$, in live coral and rubble, 03.11.2015. Leg. H. Morrison (TP 4679, 1 p.v.).

\section{DESCRIPTION}

Shell rather large (H 50-66 mm), solid and elongate, subquadrate, subequilateral and strongly inflated. Juveniles more rounded. Margins gently rounded except for nearly straight posterior margin. Between 36-41 radial ribs. Anterior and medial ribs with pronounced, closely set imbricating scales, rounded on anterior slope, more or less chevron-shaped and slightly transverse on central part. Posterior ribs with raised, transverse imbricating scales, more distantly placed and wearing off easily. Interstices with fine growth striae. Lunule and escutcheon narrow but clearly defined. Hinge plate strong, broad and weakly arched. Exterior coloration ranging from white or yellow to pinkish, mottled with tan-orange or brownish blotches. Lunule and escutcheon may be pink or purple. Interior white with the umbonal cavity occasionally pale cream; margins rarely reddish brown or yellowish brown.

\section{DISTRIBUTION AND ECOLOGY}

The present specimen is the first sample recovered from WA and has been collected from Martin Shoal (Figures 16A-D), very close to the border of NT (Figure 1). It is taken from a depth of 16-50 metres, has 38 ribs and with a height of $64.4 \mathrm{~mm}$, is close to the maximum height known (New Caledonia, MNHN-IM-2012-33595, $\mathrm{H} 66.4 \mathrm{~mm}$ ). An additional, smaller specimen has recently been taken from Parry Shoals, NT $\left(11^{\circ} 12.5^{\prime} \mathrm{S}\right.$, $129^{\circ} 42.3^{\prime} \mathrm{E}$; colln TP 4731) and represents the first record for NT. It is a Central IWP species and ranges from W. Thailand, Indonesia, Philippines, QLD, New Caledonia, Fiji (ter Poorten 1997, 2009) and Tonga Islands, Tongatapu Island (MNHN, det. TP).

\section{REMARKS}

Unlike all its congeners, $V$. sewelli carries characteristic, regularly-placed imbricating scales on all ribs over the entire shell. It is a relatively poorly known species of which only one live specimen is known, originating from a depth of 20-30 m (New Caledonia, MNHN). Martin Shoal is located in relative close vicinity to East Timor (= Timor Leste) and Indonesia, separated by the Timor Trough (Figure 1). A record is known from the southern Indonesian Island of Sawu (colln TP 311) and this suggests that additional WA samples from the oceanic emergent offshore reefs, banks and shoals may surface, improving distributional records in the state.

\section{Vasticardium wilsoni (Voskuil \& Onverwagt, 1991)}

Figures 16G-I, 20G

Acrosterigma elongatum (Bruguière, 1789) - Wilson and Stevenson 1977: 78-80, pl. 5 figs 1-4 [= paratype of Acrosterigma wilsoni Voskuil \& Onverwagt, 1991, WAM S65194].

Trachycardium wilsoni Voskuil \& Onverwagt, 1991: 64-66, pl. 3 fig. 1.

Acrosterigma wilsoni (Voskuil \& Onverwagt, 1991) Lamprell and Whitehead 1992: pl. 28 fig. 185.

Vasticardium elongatum (J.G. Bruguière, 1789) forma wilsoni — Huber 2010: 294, fig. 


\section{MATERIAL EXAMINED}

Australia: Northern Territory: Groote, N.W. Gulf of Carpentaria, SE. end of Groote Eylandt, $14^{\circ} 12.73^{\prime} \mathrm{S}, 136^{\circ} 52.25^{\prime} \mathrm{E}$, beached, 10.09.2009. Leg. G.M. Dally (NTM P.43243, 1 s.v.); Anson Beagle, N.N.E. of Darwin, Shoal Bay, western section of Gunn Point Public Beach, Tree Point, $12^{\circ} 19.55^{\prime} \mathrm{S}$, $131^{\circ} 0.8^{\prime} \mathrm{E}$, 13.04.1996. Leg. R.C. Willan \& M.E. Chaddock (NTM P.8457, 1 s.v.); N. of Darwin, Lee Point, $12^{\circ} 19^{\prime} \mathrm{S}, 130^{\circ} 54^{\prime} \mathrm{E}, 1970$. Leg. J.G. Asendorf (NTM P.45687, 1 p.v.); Darwin, central section of Casuarina Beach, adjacent to outlet of Sandy Creek, Free Beach, $12^{\circ} 21^{\prime} \mathrm{S}, 130^{\circ} 53.03^{\prime} \mathrm{E}, 06.03 .1993$. Leg. R.C. Willan (NTM P.30714, 1 s.v.); Darwin Harbour, near East Point, approx. $1 \mathrm{~km} \mathrm{~W}$. of Dudley Point, $12^{\circ} 24.852^{\prime} \mathrm{S}, 130^{\circ} 48.692^{\prime} \mathrm{E}, 25.06 .2011$. Leg. R.C. Willan (NTM P.52928, 1 s.v.); Bonaparte, 215 miles E.N.E. of Troughton Island; $13^{\circ} 04^{\prime} \mathrm{S}, 129^{\circ} 16^{\prime} \mathrm{E}, 60 \mathrm{~m}, 23.10 .1962$. Leg. R.W. George, FRV 'Dorothea' Cruise 1962 (WAM S56973, 1 s.v.).

Australia: Western Australia: Kimberley, Institut Islands, W. side of Cassini Island, $13^{\circ} 56^{\prime} \mathrm{S}, 125^{\circ} 37^{\prime} \mathrm{E}$, $20 \mathrm{~m}$, base of wall, 22.09.1996. Leg. H. Morrison \& C. Bryce, WAM Offshore Kimberley Survey 1996 (WAM S57107, 1 p.v.); Heritage Reef, $14^{\circ} 15^{\prime} \mathrm{S}$, 12509'E, 3-15 m, 20.08.1991. Leg. F. Wells \& C. Bryce, WAM Kimberley Islands \& Reefs Survey 1991, Stn 24 (WAM S56891, 1 s.v.); Leonie Island, $16^{\circ} 25^{\prime} \mathrm{S}$, 12303'E, intertidal, 18.11.1994. Leg. F. Wells \& C. Bryce, WAM Southern Kimberley Survey 1994, Stn 6 (WAM S57097, 1 s.v.); Canning, Beagle Bay, 1652'S, $122^{\circ} 32^{\prime} \mathrm{E}, 9 \mathrm{~m}$, garden bottom, 25.08.1997. Leg. C. Bryce, Arrow Pearls Beagle Bay Fauna Survey 1997 (WAM S57095, 2 s.v.; WAM S57096, 1 s.v.); Lacepede Islands, N. side of West Island, $16^{\circ} 51^{\prime} \mathrm{S}, 122^{\circ} 07^{\prime} \mathrm{E}$, intertidal sand, rock and mud, 27.08.1991. Leg. F. Wells \& C. Bryce, WAM Kimberley Islands \& Reefs Survey 1991, Stn 44 (WAM S56892, 1 s.v.); Coulomb Point, $17.42025^{\circ} \mathrm{S}, 122.075083^{\circ} \mathrm{E}, 11.5 \mathrm{~m}, 15.06 .2008$. Leg. J. Keesing, CSIRO Survey June 2008, Stn 2037(b) (WAM S44428, 1 p.v., A); Broome, intertidal sand and mud, at extreme low tide (TP 915, 1 p.v.); Lagrange Bay, Black Rocks, 18³4'S, 121 $44^{\circ} \mathrm{E}$, beach collection, 09.1985 (WAM S65195, 2 s.v.); North West Shelf, 50 miles N.E. of Adele Island, $14^{\circ} 59^{\prime} \mathrm{S}, 123^{\circ} 40^{\prime} \mathrm{E}, 100 \mathrm{~m}$, 20.10.1962. Leg. R.W. George, FRV 'Dorothea' Cruise 1962 (WAM S56886, ex 723-66, 1 s.v.); 10-20 miles W. of Lagrange Bay, $18^{\circ} 39^{\prime} \mathrm{S}, 121^{\circ} 42^{\prime} \mathrm{E}, 20-45 \mathrm{~m}$, 13.10.1962. Leg. R.W. George, FRV 'Dorothea' Cruise 1962 (WAM S56889, ex 731-66, 1 s.v.); 40 miles W. of Cape Jaubert, $18^{\circ} 56^{\prime} \mathrm{S}, 120^{\circ} 55^{\prime} \mathrm{E}, 40 \mathrm{~m}, 13.10 .1962$. Leg. R.W. George, FRV 'Dorothea' Cruise 1962 (WAM S56888, ex 711-66, 1 s.v.); S.E. of Mermaid Reef, $17^{\circ} 46^{\prime} 6.23^{\prime \prime S}, 120^{\circ} 43^{\prime} 9.12^{\prime \prime E}$ to $17^{\circ} 45^{\prime} 56.87^{\prime \prime S}$, 12042'56.51"E, 97-109 m, 20.06.2007. Leg. C. Whisson \& O. Gomez, CSIRO RV 'Southern Surveyor' Cruise, Stn SS0507/097 (WAM S32851, 1 s.V., WAM S32852, 1 s.v.; WAM S34664, 1 s.v.), S.E. of Imperieuse Reef, $18.4602^{\circ} \mathrm{S}, 120.1447^{\circ} \mathrm{E}$ to $18.462^{\circ} \mathrm{S}, 120.1447^{\circ} \mathrm{E}, 80-81$ m. 19.06.2007. Leg. C. Whisson \& O. Gomez, CSIRO RV 'Southern Surveyor' Cruise, Stn SS0507/082 (WAM S34670, 1 s.v.); 60 miles N.W. of Bedout Island, 1856'S, $118^{\circ} 28^{\prime} \mathrm{E}, 50 \mathrm{~m}, 12.10 .1962$. Leg. R.W. George, FRV 'Dorothea' Cruise 1962 (WAM S56887, ex 877-66, 5 s.v.); Pilbara Nearshore/Offshore, off Port Hedland, $20^{\circ} 19^{\prime} \mathrm{S}, 118^{\circ} 36^{\prime} \mathrm{E}$, rectangular dredge, 03.10.1982. Leg. L.M. Marsh \& M. Bezant, CSIRO FRV 'Soela' Cruise V 1982 (WAM S78272, 1 s.v.); Port Hedland, Cape Keraudren, low tide, 1973 (NMR993000015970, 3 p.v., paratypes); 38 nautical miles N. of Port Walcott, $19^{\circ} 59^{\prime} \mathrm{S}, 117^{\circ} 16^{\prime} \mathrm{E}$, silty sand and bryozoa, 50-52 m, 15.04.1982. Leg. L.M. Marsh, CSIRO FRV 'Soela' Cruise II 1982, Stn SO2/82/54A (WAM S78278, 1 s.v.); Dampier Archipelago, Dolphin Island, W. coast near N. end, $20^{\circ} 25.77^{\prime} \mathrm{S}, 116^{\circ} 52.68^{\prime} \mathrm{E}$, intertidal, 27.10.1998. Leg. S.M. Slack-Smith \& C.W. Bryce, Woodside Dampier Exped. I 1998, Stn DA1/98/28 (WAM S18251, 1 s.v.); Dolphin Island, N. section of E. coast, $20^{\circ} 28.09^{\prime} \mathrm{S}$, $116^{\circ} 51.91^{\prime} E$, intertidal, 17.10.1998. Leg. S.M. SlackSmith \& C.W. Bryce, Woodside Dampier Exped. I 1998, Stn DA1/98/02 (WAM S18212, 1 s.v.); E. side of Collier Rocks, $20^{\circ} 24.81^{\prime} \mathrm{S}, 116^{\circ} 50.68^{\prime} \mathrm{E}$, intertidal, dead \& live coral, 24.10.1998. Leg. S.M. Slack-Smith \& C.W. Bryce, Woodside Dampier Exped. I 1998, Stn DA1/98/20 (WAM S18203, 1 s.v.); S.W. of Cohen Island, rock-armoured pipeline, $20^{\circ} 24.47^{\prime} \mathrm{S}, 116^{\circ} 46.30^{\prime} \mathrm{E}$, 15-19 m, 08.09.1999. Leg. S.M. Slack-Smith et al., Woodside Dampier Exped. III 1999, Stn DA3/99/69 (WAM S22479, 1 s.v.); N. of Nelson Rocks, 20²6.51'S, $116^{\circ} 40.23^{\prime} \mathrm{E}, 17 \mathrm{~m}$, sponges, gorgonians, large coral bommies, 07.09.1999. Leg. S.M. Slack-Smith et al., Woodside Dampier Exped. III 1999, Stn DA3/99/67 (WAM S22459, 2 s.v.); Dampier Archipelago, E. coast of West Lewis Island, $20^{\circ} 34.66^{\prime} \mathrm{S}, 116^{\circ} 39.72^{\prime} \mathrm{E}, 5 \mathrm{~m}$, little coral, 04.09.1999. Leg. S.M. Slack-Smith et al., Woodside Dampier Exped. III 1999, Stn DA3/99/61 (WAM S22477, 1 s.v.); East Lewis Island, Bay on S. coast of, $20^{\circ} 37.50^{\prime} \mathrm{S}, 116^{\circ} 39.18^{\prime} \mathrm{E}$, intertidal, 05.09.1999. Leg. S.M. Slack-Smith et al., Woodside Dampier Exped. III 1999, Stn DA3/99/62 (WAM S22457, 3 s.v.); East Lewis Island, W. coast, near N. point, 20³6.00'S, $116^{\circ} 39.00^{\prime} E$, intertidal, 05.09.1999. Leg. S.M. SlackSmith et al., Woodside Dampier Exped. III 1999, Stn DAIrr/EL (WAM S22460, 1 s.v.); Georgeff Reef, $20^{\circ} 29.34$ 'S, $116^{\circ} 36.80^{\prime} \mathrm{E}$, intertidal reef, 28.08.1999. S.M. Slack-Smith et al., Woodside Dampier Exped. III 1999, Stn DA3/99/42 (WAM S22455, 1 s.v.); channel between Enderby Island \& West Lewis Island, $20^{\circ} 35.11^{\prime} \mathrm{S}, 116^{\circ} 35.62^{\prime} \mathrm{E}, 18 \mathrm{~m}$, sponges, soft corals \& gorgonians, 02.09.1999. Leg. S.M. Slack-Smith et al., Woodside Dampier Exped. III 1999, Stn DA3/99/55 (WAM S22437, 1 s.v.; WAM S22456, 2 s.v.; WAM S22475, 1 p.v.); Rosemary Island, $20^{\circ} 29^{\prime}$ S, $116^{\circ} 35^{\prime} \mathrm{E}$, 08.1961. Leg. B. Wilson \& G. Kendrick (WAM S65194, ex 732-66, 1 p.v., paratype); N. of Dampier, $20^{\circ} 19^{\prime} 33.1^{\prime \prime S}, 116^{\circ} 33^{\prime} 22.11^{\prime \prime E}$, from sediment in 
retrieved pipes. Leg. R. Nunn (WAM S84499, 1 p.v., A); $40 \mathrm{~km}$ offshore from Burrup Peninsula, 20 ${ }^{\circ} 19^{\prime} 33.1^{\prime \prime S}$, $116^{\circ} 33^{\prime} 22.11^{\prime \prime E}$. Leg. R. Nunn (WAM S84498, 1 p.v., A); S. side of Goodwyn Island, $20^{\circ} 32.43^{\prime} \mathrm{S}, 116^{\circ} 32.68^{\prime} \mathrm{E}$, $5 \mathrm{~m}$, coral bommies, 31.08.1999. Leg. S.M. SlackSmith et al., Woodside Dampier Exped. III 1999, Stn DA3/99/49 (WAM S22467, 1 fragm.); Mermaid Passage, on surface of comminuted rubble incorporating some silt, $20^{\circ} 42.42^{\prime} \mathrm{S}, 116^{\circ} 30.31^{\prime} \mathrm{E}, 21.08 .1994$. Leg. R.C. Willan (NTM P.21679, 4 p.v., 2 s.v.); Enderby Island, S.W. of Rocky Head, $20^{\circ} 37.10^{\prime} \mathrm{S}, 116^{\circ} 26.728^{\prime} \mathrm{E}, 14 \mathrm{~m}$, sponges \& soft corals, 06.09.1999. Leg. S.M. SlackSmith et al., Woodside Dampier Exped. III 1999, Stn DA3/99/65 (WAM S22458, 2 s.v.; WAM S22478, 1 s.v.); N. of N.W. point of Eaglehawk Island, 20 $38.94 '$ S, $116^{\circ} 26.22^{\prime} \mathrm{E}$, dive, sponges, soft corals gorgonians, 10 m, 03.09.1999. Leg. S.M. Slack-Smith et al., Woodside Dampier Exped. III 1999, Stn DA3/99/56 (WAM S22476, 2 s.v.); Dampier, by pearl divers by 'fanning the sand' in sponge garden reef with sandy holes, $35 \mathrm{~m}$ (TP 2012, 1 p.v.); Dampier, Back Beach, 1987 (TP 2086, 2 p.v., paratypes); Dampier (TP 2088, 1 p.v., paratype); Montebello Islands, S. of Gannet Island to E. of Delta Island, $20^{\circ} 27^{\prime} \mathrm{S}, 115^{\circ} 33^{\prime} 59^{\prime \prime} \mathrm{E}, 4-6 \mathrm{~m}$, grey sand, 14.08.1993. Leg. S.M. Slack-Smith, WAM Montebello Islands Survey 1993, Stn MB12 (WAM S78391, 1 s.v.); Exmouth Gulf, Hawksbill Exploration Field, 14 km E. of Muiron Islands, $21^{\circ} 41^{\prime} \mathrm{S}, 114^{\circ} 31^{\prime} \mathrm{E}, 15 \mathrm{~m}, 16.01 .1994$. Leg. Apache Energy (WAM S78276, 1 p.v.); Exmouth Bay (ZMA, 1 p.v.); Exmouth Gulf, by diver, on coarse sand and sponge growth, $22 \mathrm{~m}$ (TP 913, 1 p.v.); Exmouth Gulf, by diver, 24 m, 1998 (TP 919, 1 p.v.); Exmouth, in coarse sand and gravel, $28 \mathrm{~m}$ (TP 914, 1 p.v.); Ningaloo, Ningaloo Marine Park, $21^{\circ} 48.0168^{\prime} \mathrm{S}$ to $21^{\circ} 48.1218^{\prime} \mathrm{S}, 114^{\circ} 00.2356^{\prime} \mathrm{E}$ to $114^{\circ} 00.2791^{\prime} \mathrm{E}, 53-57 \mathrm{~m}$, sponges, bryozoans, 31.01.2008. Leg. S.M. Slack-Smith, AIMS RV Solander Cruise RV4545 February 2008, Stn RVS4545-D064 (WAM S43492, 2 s.v.; WAM S43508, 1 s.v.); Ningaloo Marine Park, $21^{\circ} 48^{\prime} 5^{\prime \prime} S, 114^{\circ} 0^{\prime} 53^{\prime \prime E}$, 47-50 m, rocks, rubble, rhodoliths, 12.02.2008. Leg. S.M. Slack-Smith, AIMS RV Solander Cruise RV4545 February 2008, Stn RVS4545-D142 (WAM S43507, 1 s.v.); Ningaloo Marine Park, $22^{\circ} 6^{\prime} 0 " \mathrm{~S}, 113^{\circ} 51^{\prime} 50^{\prime \prime} \mathrm{E}$, 51.3-55 m, sponges, rhodoliths, 10.02.2008. Leg. S.M. Slack-Smith \& M.P. Salotti, AIMS RV Solander Cruise RV4545 February 2008, Stn RVS4545-D135 (WAM S43483, 1 s.v.); Ningaloo Marine Park, off Osprey Sanctuary Zone, $22^{\circ} 18.263^{\prime} \mathrm{S}, 113^{\circ} 46.544^{\prime} \mathrm{E}$ to $22^{\circ} 18.505^{\prime} \mathrm{S}, 113^{\circ} 46.157^{\prime} \mathrm{E}, 55 \mathrm{~m}, 25.04 .2006$. Leg. M.P. Salotti, AIMS-WAM RV 'Cape Ferguson' Ningaloo Survey I, Stn CF4010\&11/2006/D005 (WAM S78355, fragm.); Ningaloo Marine Park, Point Cloates, $22^{\circ} 47^{\prime} 50^{\prime \prime} \mathrm{S}, 113^{\circ} 32^{\prime} 9^{\prime \prime} \mathrm{E}, 81.8 \mathrm{~m}, 22.08 .2008$. Leg. O.A. Gomez \& J. Colquhoun, AIMS-WAM RV 'Cape Ferguson' Ningaloo Survey IV August 2008, Stn SOL4769/2008/2-040SL01 (WAM S43904, 1 p.v., A).

\section{DESCRIPTION}

Shell large (height $75-110 \mathrm{~mm}$ ), solid, slightly inequilateral, elongate-quadrate and rather inflated. Margins rounded except for straight or slightly concave posterior margin, coinciding with internal supporting radial ridge. Between 36-43 square-sided and flat-topped radial ribs, marginally serrated, forming overlapping teeth at the postero-ventral margin. Anterior ribs with low transverse rugae, median ribs laterally rugose and posterior ribs carrying oblique scales. Interstices rather narrow, deep and unsculptured. Lunule well delimited, narrow and smooth. Exterior colour cream or brown-yellow, becoming pinkish posteriorly; interior white with pink posterior margin and cream umbonal cavity.

\section{DISTRIBUTION AND ECOLOGY}

In WA, it has an exclusively inshore and continental shelf distribution (Figure 20G), occurring parapatrically alongside its sister species, $V$. elongatum, which is confined to the oceanic emergent reefs of the shelf margin (see also under that species). Its occurrence in NT is well established by the presence of six NTM/ WAM samples, the largest of which (NTM P.43243, H $110 \mathrm{~mm}$ ) is from the Gulf of Carpentaria, S.E. of Groote Eylandt.

\section{REMARKS}

The type material selected by Voskuil and Onverwagt (1991) is a composite of two taxa: the paratype from Indonesia, Moluccas (RMNH.MOL.56585, ex colln Geologisch Museum Wageningen, 1941; Hylleberg 2004: 872 , unnumbered fig.) corresponds morphologically with $V$. elongatum, but not $V$. wilsoni (see under $V$. elongatum for assigning specific status to all taxa in the elongatum complex). Vidal (1993: 45) considered it 'rather different from the holotype'. A paratype labelled 'Fiji Islands' (Leg. H. Dabbert, RMNH.MOL.56584; Hylleberg 2004: 872, unnumbered fig.) does belong to $V$. wilsoni; regarding its provenance, Jeroen Goud (RMNH) communicated (e-mail 23.03.2015) that the origin of the Dabbert material is unreliable and should be treated as untrustworthy. Although few northeast QLD samples are listed by Voskuil and Onverwagt (1991), Vidal (1993) limits the E. end of the distribution to the Torres Strait. As no supplementary trustworthy QLD material has been encountered and in the absence of other nonAustralian records, $V$. wilsoni is considered an endemic Dampierian species. Vasticardium wilsoni is easily separated from the related $V$. coralense (Vidal, 1993) by its elongate-quadrate shape and by its straight to slightly concave posterior margin, coinciding with a strong internal supporting radial ridge (Figure 16H, arrow).

Cardium (Trachycardium) serricostatum Melvill \& Standen, 1899 has been described based on material from Torres Strait: between Ormans Reef and the 'Brothers Island', 6-7 fms, 18.08.1888 (stn 4) and Murray Island, Mèr, fringing reef (stn 13). Prof. A.C. 
Haddon Exped. 1888-1889. A syntype (NHMUK 1899.2.23.10; Figures 16E-F) is a rather worn left valve, has a height of $21.5 \mathrm{~mm}$ and 40 ribs. The accompanying labels only refer to 'Torres Straits', include the word 'type' and the source: A.C. Haddon. It closely matches the type figure and is the appropriate size $(20 \mathrm{~mm})$. This valve does not have an internal supporting radial ridge (present also in the juvenile stage of $V$. wilsoni) and has a rounded posterior margin. Vidal (1993: 45) concluded that it represents 'a juvenile specimen of $V$. elongatum'. This is unlikely as it would be well outside the known distribution range of $V$. elongatum (see under that species). Compared to the related $V$. coralense (Vidal, 1993) from New Caledonia, QLD material has a higher rib number (39-42, $\mathrm{n}=4$ versus $34-38, \mathrm{n}=26$ ), broader and deeper interstices, much better developed ribs on the posterior slope and is much less colourful. QLD samples also lack the typical pink coloured internal margin of $V$. coralense. WAM S78076 (ex 4777-68), figured by Vidal (1993: pl. 1 fig. 2, pl. 2 fig. 4) and Wells and Bryce (1985: pl. 63 fig. 600), originates from QLD (Cape York) and agrees with this material. Based on the available samples, $V$. serricostatum is tentatively considered a distinct species, separated from $V$. wilsoni by a more rounded shape, lacking an internal supporting ridge and separated from $V$. coralense by a higher rib number, more prominent ribbing and a different coloration.

\section{EXCLUDED SPECIES}

1. Vepricardium incarnatum (Reeve, 1844)

A specimen of $V$. incarnatum, erroneously identified by Voskuil and Onverwagt (1988: pl. 2 figs 1-2) as $V$. multispinosum (Sowerby, 1841) was stated to originate from 'Dampier Archipelago, W. Australia' (now in colln TP 2746). The misidentification was noted by Vidal (2000). This locality is considered erroneous as no other WA records exist. The true distribution of $V$. incarnatum is limited to the Vietnam - Philippines — N. Indonesia region. A shell said to come from QLD, figured by Lamprell and Whitehead (1992: fig. 184) and identified as $V$. incarnatum refers to $V$. coronatum (Schröter, 1786), which also does not occur in Australia.

2. Acrosterigma abrolhense Vidal, 1999

This species was originally described from the Houtman Abrolhos Islands, a small series of low coral islands located in the Western Overlap Zone, at the confluence of the Flindersian Province and the Dampierian Province. Acrosterigma abrolhense was compared with its closest species, A. cygnorum (Deshayes, 1855) by Vidal (1999). We revisited this species during the course of our work (the first author examined TP 2037 from Shark Bay, possibly the most northern record; also WAM S77961, S77962, S77963 and S78325 from the Houtman Abrolhos Islands which all belong to cygnorum as well as S78390, S79279 and S79280 from off
Dongara). We find an alternate interpretation more likely and propose that $A$. abrolhense represents both juvenile $A$. cygnorum material, but also northernendpoint range variation within $A$. cygnorum, with an acceptable level of intraspecific variation. For example, the rib number for abrolhense given by Vidal (1999), 43-46, falls within the rib number of cygnorum, 36-47, given by the same author. Therefore we propose that $A$. abrolhense be recognised as a syn. nov. of $A$. cygnorum.

\section{RESULTS}

\section{WESTERN AUSTRALIAN TRENDS IN CARDIIDAE}

Sixty-eight species of cardiid are recognised from WA and updated nomenclature is provided for taxa previously recognised by Wilson and Stevenson (1977). An overview of the cardiid species is tabulated as follows: AIOT (Table 3), WA (Table 4), QLD species not reported from WA (Table 5) and South/East and North/East end of ranges of WA species (Table 6). The newly described species are all somewhat restricted in their distribution, while new records that are not new species, represent wideranging members of the IWP fauna. The four newly described species are Acrosterigma extremattenuatum sp. nov. (Figures 13-14), Ctenocardia pilbaraensis sp. nov. (Figures 8A-L), Microcardium scabrosum sp. nov. (Figures 3I-M, 4A-F) and Pratulum occidentale sp. nov. (Figures 5A-F, 6A-M); all of these new species are found in deeper waters. Pratulum occidentale sp. nov. is endemic to WA (Figure 17F). The other three new species, C. pilbaraensis sp. nov., A. extremattenuatum sp. nov., and $M$. scabrosum sp. nov. are found inshore (Pilbara, Figure 18C and latter two from northern Australia, Figures 20B and 17E, respectively). Sixteen taxa are new records for Western Australia and 14 are new records for Australia. No new records are presented for southern cardiid taxa. Records confirm the well known distinction between inshore/offshore areas of the northwest shelf, with sixteen taxa found restricted to offshore islands and shoals (e.g. Vasticardium philippinense, $V$. elongatum, Corculum cardissa, Ctenocardia fornicata, C. gustavi), and a smaller cohort found exclusively inshore (e.g. A. extremattenuatum sp. nov., V. wilsoni, C. pilbaraensis sp. nov.) (Figure 21). Previous records collated here document seven species of giant clam in WA.

\section{COMPARISON BETWEEN WESTERN AUSTRALIAN AND AUSTRALIAN INDIAN OCEAN TERRITORIES (AIOT) CARDIIDAE}

While 68 species of cardiid are recognised from WA only a subset of this fauna, 16 species in total, are known from the Christmas and Cocos-Keeling Islands of the AIOT (Table 3). Nearly all taxa reported from AIOT are also known from WA and nearly all represent 
wide-ranging members of the IWP fauna found offshore in WA. Two taxa from Cocos-Keeling Islands represent new records for Australia: Fulvia dulcis and 'Fulvia' lineonotata. Eleven taxa are reported from Christmas Island while 14 taxa are reported from Cocos-Keeling (Afrocardium richardi and Fragum mundum are absent from Cocos-Keeling, while Fragum fragum, Fragum sueziense, Fulvia australis, Fulvia dulcis and 'Fulvia' lineonotata are absent from Christmas Island). Six giant clam species are reported from Christmas and CocosKeeling Islands of the AIOT.

\section{COMPARISON BETWEEN WESTERN AUSTRALIAN AND NORTHERN TERRITORY CARDIIDAE}

Twenty-five cardiids are recognised from the NT, including two of the newly described species, Acrosterigma extremattenuatum sp. nov. and Microcardium scabrosum sp. nov. (Table 4). Updated nomenclature is provided. Seven new records for the
NT were found; Afrocardium richardi (Figure 19A), Fragum whitleyi (Figure 18F) Frigidocardium torresi (Figure 17C), Fulvia australis (Figure 19C), Fulvia hungerfordi (Figure 19D), Vasticardium philippinense (Figure 20F) and V. sewelli; all are well known members of the IWP fauna and in WA, most are found on the offshore reefs. Previous records document four species of giant clam in the NT.

\section{COMPARISON BETWEEN WESTERN AUSTRALIAN AND QUEENSLAND CARDIIDAE}

Eighteen species of cardiid from ten different genera are recognised from QLD that are not yet known in WA (Table 5, based on material verified by the first author). Four of these are new records for Queensland; Afrocardium exochum, Frigidocardium sp. nov. 1, Fulvia fragiformis and $F$. hungerfordi. All of these new records were found in non-QM collections.

TABLE 3 Cardiidae species from the Australian Indian Ocean Territories (IOT) of Christmas Island and Cocos (Keeling) Islands, based on material verified by the authors or with literature data.

\begin{tabular}{|c|c|c|}
\hline Species & Christmas Island & Cocos (Keeling) Islands \\
\hline Afrocardium richardi (Audouin, 1826) & $\begin{array}{l}\text { NHMUK 1911.2.26.14-15 (syntypes of } \\
\text { Cardium rubescens E.A. Smith, 1911) }\end{array}$ & - \\
\hline Corculum cardissa (Linnaeus, 1758) & Tan and Low (2014) & WAM S57058 \\
\hline Fragum fragum (Linnaeus, 1758) & - & $\begin{array}{l}\text { WAM S57053-S57057, S57059-S57060, } \\
\text { S57069, S57080, S79511 }\end{array}$ \\
\hline Fragum mundum (Reeve, 1845) & UF 337833 & - \\
\hline Fragum sueziense (Issel, 1869) & - & UF 338198 \\
\hline Fulvia australis (G.B. Sowerby II, 1834) & - & UF 338200 (mixed sample) \\
\hline Fulvia dulcis (Deshayes, 1863) & - & $\begin{array}{l}\text { UF } 338200 \text { (mixed sample; } \\
\text { first record for Australia) }\end{array}$ \\
\hline 'Fulvia' lineonotata Vidal, 1994 & - & $\begin{array}{l}\text { UF } 338200 \text { (mixed sample; } \\
\text { first record for Australia) }\end{array}$ \\
\hline Tridacna crocea Lamarck, 1819 & Tan and Low (2014) & WAM S57200, S57215, S57231 \\
\hline Tridacna derasa (Röding, 1798) & Tan and Low (2014) & USNM 654256 \\
\hline Tridacna gigas (Linnaeus, 1758) & Tan and Low (2014) & Tan and Low (2014); Wells (1994) \\
\hline Tridacna maxima (Röding, 1798) & $\begin{array}{l}\text { WAM S57204, S57207-S57208, } \\
\text { S57210-S57211, S57217-S57219, } \\
\text { S76780-S76781 }\end{array}$ & WAM S57216 \\
\hline Tridacna noae (Röding, 1798) & WAM S57203, S57209, S57212, S57233 & $\begin{array}{l}\text { WAM S57213, S57214, S57224-S57225, } \\
\text { S76786, S84351 }\end{array}$ \\
\hline Tridacna squamosa Lamarck, 1819 & Tan and Low (2014); Wells et al. (1990) & WAM S57232 \\
\hline Vasticardium angulatum (Lamarck, 1819) & Tan and Low (2014) & $\begin{array}{l}\text { WAM S56938-S56940, S56936-S56937, } \\
\text { S56991-S56992 }\end{array}$ \\
\hline Vasticardium philippinense (Hedley, 1899) & WAM S56834-S56845, S57125, TP 4405 & WAM S56984-S56990, S76771 \\
\hline
\end{tabular}


TABLE 4 Western Australia Cardiidae species as currently recognised (Tridacninae included). NT, verified record(s) known from the Northern Territory; S.A., endemic southern Australia; WA, endemic Western Australia; IWP, Indo-West Pacific; NOR, so far exclusively known from the northern offshore reefs and shoals.

\begin{tabular}{|c|c|c|c|c|c|}
\hline No & Species & Distribution & NOR & NT & Source WA Presence \\
\hline 1 & Acrosterigma biradiatum (Bruguière, 1789) & IWP & & • & Wilson and Stevenson (1977) \\
\hline 2 & Acrosterigma cygnorum (Deshayes, 1855) & S.A. & & & Wilson and Stevenson (1977) \\
\hline 3 & Acrosterigma dianthinum (Melvill \& Standen, 1899) & IWP & • & & Present study \\
\hline 4 & Acrosterigma extremattenuatum sp. nov. & N.Austr. & & • & $\begin{array}{l}\text { Wilson and Stevenson (1977) } \\
\text { (as L. attenuatum) }\end{array}$ \\
\hline 5 & Acrosterigma impolitum (G.B. Sowerby II, 1834) & IWP & & • & Wilson and Stevenson (1977) \\
\hline 6 & Acrosterigma marielae Wilson \& Stevenson, 1977 & WA & & & Wilson and Stevenson (1977) \\
\hline 7 & Acrosterigma punctolineatum Healy \& Lamprell, 1992 & IWP & & • & (Willan et al. 2015) \\
\hline 8 & Acrosterigma simplex (Spengler, 1799) & IWP & & & Present study \\
\hline 9 & Acrosterigma suduirauti Vidal \& ter Poorten, 2007 & IWP & • & & Present study \\
\hline 10 & Acrosterigma transcendens (Melvill \& Standen, 1899) & IWP & & & Wilson and Stevenson (1977) \\
\hline 11 & Acrosterigma variegatum (G.B. Sowerby II, 1840) & IWP & & & Present study \\
\hline 12 & Afrocardium richardi (Audouin, 1826) & IWP & & • & Present study \\
\hline 13 & Corculum cardissa (Linnaeus, 1758) & IWP & • & & Wells and Slack-Smith (1986) \\
\hline 14 & Ctenocardia fornicata (G.B. Sowerby II, 1840) & IWP & • & & Present study \\
\hline 15 & Ctenocardia gustavi Vidal \& Kirkendale, 2007 & IWP & • & & (Willan et al. 2015) \\
\hline 16 & Ctenocardia pilbaraensis sp. nov. & IWP & & & $\begin{array}{l}\text { Wilson and Stevenson (1977) } \\
\text { (as C. fornicata) }\end{array}$ \\
\hline 17 & Ctenocardia virgo (Reeve, 1845) & IWP & & • & Wilson and Stevenson (1977) \\
\hline 18 & Fragum erugatum (Tate, 1889) & IWP & & & Wilson and Stevenson (1977) \\
\hline 19 & Fragum fragum (Linnaeus, 1758) & IWP & & & Wilson and Stevenson (1977) \\
\hline 20 & Fragum mundum (Reeve, 1845) & IWP & & & (Willan et al. 2015) \\
\hline 21 & Fragum sp. aff. scruposum (Deshayes, 1855) & IWP & & & Present study \\
\hline 22 & Fragum sueziense (Issel, 1869) & IWP & & & ter Poorten (2009) \\
\hline 23 & Fragum unedo (Linnaeus, 1758) & IWP & & & Wilson and Stevenson (1977) \\
\hline 24 & Fragum whitleyi Iredale, 1929 & IWP & & • & Present study \\
\hline 25 & Freneixicardia victor (Angas, 1872) & IWP & & & Wilson and Stevenson (1977) \\
\hline 26 & Frigidocardium eos (Kuroda, 1929) & IWP & & & Huber and ter Poorten (2007) \\
\hline 27 & Frigidocardium helios ter Poorten \& Poutiers, 2009 & IWP & & & Present study \\
\hline 28 & Frigidocardium iris Huber \& ter Poorten, 2007 & IWP & & & Huber and ter Poorten (2007) \\
\hline 29 & Frigidocardium torresi (E.A. Smith, 1855) & IWP & & - & ter Poorten (2009) \\
\hline 30 & Fulvia aperta (Bruguière, 1789) & IWP & & & Wilson and Stevenson (1977) \\
\hline 31 & Fulvia australis (G.B. Sowerby II, 1834) & IWP & & • & (Willan et al. 2015) \\
\hline \multirow[t]{2}{*}{32} & Fulvia boholensis Vidal, 1994 & IWP & & & Vidal (1994) \\
\hline & *Fulvia hungerfordi (G.B. Sowerby III, 1901) & & & - & $*($ not in WA $)$ \\
\hline 33 & Fulvia laevigata (Linnaeus, 1758) & IWP & & • & ter Poorten (2009) \\
\hline 34 & Fulvia scalata Vidal, 1994 & IWP & & & Vidal (1994) \\
\hline 35 & Fulvia tenuicostata (Lamarck, 1819) & S.A. & & & Wilson and Stevenson (1977) \\
\hline 36 & Fulvia undatopicta (Pilsbry, 1904) & IWP & & & Present study \\
\hline 37 & 'Laevicardium' lobulatum (Deshayes, 1855) & IWP & • & & Present study \\
\hline 38 & Lunulicardia tumorifera (Lamarck, 1819) & WA & & & $\begin{array}{l}\text { Wilson and Stevenson (1977) } \\
\text { (as L. hemicardium) }\end{array}$ \\
\hline 39 & Lunulicardia retusa (Linnaeus, 1767) & IWP & & • & Wilson and Stevenson (1977) \\
\hline 40 & Lyrocardium aurantiacum (A. Adams \& Reeve, 1850) & IWP & & & Present study \\
\hline 41 & Lyrocardium lyratum (G.B. Sowerby II, 1840) & IWP & & - & Wilson and Stevenson (1977) \\
\hline 42 & Maoricardium fraseri (Garrard, 1963) & N.Austr. & & & Wilson and Stevenson (1977) \\
\hline
\end{tabular}




\begin{tabular}{|c|c|c|c|c|c|}
\hline No & Species & Distribution & NOR & NT & Source WA Presence \\
\hline 43 & Maoricardium setosum (Redfield, 1848) & IWP & & • & Wilson and Stevenson (1977) \\
\hline 44 & Microcardium sakuraii (Habe, 1961) & IWP & • & & ter Poorten (2009) \\
\hline 45 & Microcardium scabrosum sp. nov. & N.Austr. & & • & Poutiers (1992) \\
\hline 46 & Microfragum festivum (Deshayes, 1855) & IWP & • & & Willan (2005) \\
\hline 47 & Nemocardium probatum (Iredale, 1927) & N.Austr. & & • & Wilson and Stevenson (1977) \\
\hline 48 & Pratulum occidentale sp. nov. & WA & & & Poutiers (1992) \\
\hline 49 & Pratulum thetidis (Hedley, 1902) & S.A. & & & Wilson and Stevenson (1977) \\
\hline 50 & Trifaricardium morrisoni ter Poorten \& Huber, 2007 & WA & & & ter Poorten and Huber (2007) \\
\hline 51 & Trifaricardium nomurai Kuroda \& Habe, 1951 & IWP & • & & ter Poorten and Huber (2007) \\
\hline 52 & Vasticardium angulatum (Lamarck, 1819) & IWP & & • & Wilson and Stevenson (1977) \\
\hline 53 & Vasticardium dupuchense (Reeve, 1845) & WA & & & Wilson and Stevenson (1977) \\
\hline 54 & Vasticardium elongatum (Bruguière, 1789) & IWP & • & & Present study \\
\hline 55 & Vasticardium fultoni (G.B. Sowerby III, 1916) & WA & & & Wilson and Stevenson (1977) \\
\hline 56 & Vasticardium mindanense (Reeve, 1844) & IWP & • & & Present study \\
\hline 57 & Vasticardium philippinense (Hedley, 1899) & IWP & • & & Lamprell and Whitehead (1992) \\
\hline 58 & Vasticardium sewelli (Prashad, 1932) & IWP & • & • & Present study \\
\hline 59 & Vasticardium vertebratum (Jonas, 1844) & IWP & & • & Wilson and Stevenson (1977) \\
\hline 60 & Vasticardium wilsoni (Voskuil \& Onverwagt, 1991) & N.Austr. & & • & Voskuil and Onverwagt (1991) \\
\hline 61 & Vepricardium multispinosum (G.B. Sowerby II, 1839) & IWP & & • & Wilson and Stevenson (1977) \\
\hline 62 & Hippopus hippopus (Linnaeus, 1758) & IWP & & & Rosewater (1965) \\
\hline 63 & Tridacna (Chametrachea) crocea Lamarck, 1819 & IWP & • & & Wells and Slack-Smith (1986) \\
\hline 64 & Tridacna (Chametrachea) maxima (Röding, 1798) & IWP & & • & Rosewater (1965) \\
\hline 65 & Tridacna (Chametrachea) noae (Röding, 1798) & IWP & & & Penny and Willan (2014) \\
\hline 66 & Tridacna (Chametrachea) squamosa Lamarck, 1819 & IWP & & • & Hedley (1921) \\
\hline 67 & Tridacna (Tridacna) derasa (Röding, 1798) & IWP & • & • & Bryce and Whisson (2009) \\
\hline 68 & Tridacna (Tridacna) gigas (Linnaeus, 1758) & IWP & • & • & Wells and Slack-Smith (1986) \\
\hline
\end{tabular}

TABLE 5 Queensland Cardiidae species so far not reported from WA, based on personally verified material.

\begin{tabular}{llll} 
No & Species & Source OLD presence & New OLD record \\
\hline 1 & Acrosterigma attenuatum (G.B. Sowerby II, 1841) & ZMA, TP \\
2 & Acrosterigma hobbsae Vidal, 1999 & NTM & AMS, MNHN, NTM, WAM \\
3 & Acrosterigma kerslakae Healy \& Lamprell, 1992 & NTM, ZMA, TP \\
4 & Acrosterigma maculosum (W. Wood, 1815) & MNHN \\
5 & Afrocardium exochum (Melvill \& Standen, 1907) & NTM \\
6 & Fragum vanuatuense ter Poorten, 2015 & WAM \\
7 & Frigidocardium sp. nov. 1 & NTM \\
8 & Fulvia fragiformis Vidal, 1994 & WAM \\
9 & Fulvia hungerfordi (G.B. Sowerby III, 1901) & NHMUK, NTM, ZMA \\
10 & Fulvia nienkeae ter Poorten, 2012 & Lamprell and Healy (1998: fig. 739) \\
11 & Lunulicardia auricula (Niebuhr in Forsskål, 1775) & MNHN, NTM, WAM \\
12 & Lunulicardia hemicardium (Linnaeus, 1758) & \\
& (in agreement with forma guichardi) & MNHN, NTM, TP \\
13 & Maoricardium pseudolatum Voskuil \& Onverwagt, 1991 & MNHN, NMR, NTM, WAM, TP \\
14 & Microfragum subfestivum Vidal \& Kirkendale, 2007 & AMS, WAM \\
15 & Trifaricardium sp. nov. 1 sensu Poutiers, 1992 & NTM, WAM, TP \\
16 & Vasticardium serricostatum (Melvill \& Standen, 1899) & NTM, ZMA, TP \\
17 & Vasticardium flavum (Linnaeus, 1758) & NTM, WAM, ZMA, TP \\
18 & Vasticardium pectiniforme (Born, 1780) &
\end{tabular}


TABLE 6 South/East and North/East end of ranges of Western Australia Cardiidae species. Only trustworthy records are included (i.e. with detailed locality data and known collector). More samples are given when nearby localities are involved. For species known from a single sample only the South/East end is given. Subfossil material is excluded. References to figured samples are given in bold type; an asterisk $\left({ }^{*}\right)$ indicates that the sample is figured by Wilson and Stevenson (1977). Total number of examined WA cardiid samples: 1874 (main sources: WAM, TP, NTM, AMS and ZMA).

\begin{tabular}{|c|c|c|c|}
\hline No. & Species & WA S./E. end of distribution & WA N./E. end of distribution \\
\hline 1 & Acrosterigma biradiatum & $\begin{array}{l}\text { Ningaloo, } \\
22^{\circ} 06^{\prime} \mathrm{S}, 113^{\circ} 52^{\prime} \mathrm{E} \text { (WAM S43486) }\end{array}$ & $\begin{array}{l}\text { Yankawingarri Island, } \\
14^{\circ} 09^{\prime} \mathrm{S}, 125^{\circ} 39^{\prime} \mathrm{E} \text { (WAM S56797; WAM S56798); } \\
\text { Ashmore Reef, } \\
12^{\circ} 12^{\prime} \mathrm{S}, 123^{\circ} 03^{\prime} \mathrm{E} \text { (WAM S75358) }\end{array}$ \\
\hline 2 & A. cygnorum & $\begin{array}{l}\text { Recherche Archipelago, } \\
34^{\circ} 06^{\prime} \mathrm{S}, 123^{\circ} 11^{\prime} \mathrm{E} \text { (WAM S79235) }\end{array}$ & $\begin{array}{l}\text { Houtman Abrolhos Islands, } \\
28^{\circ} 22^{\prime} \mathrm{S}, 114^{\circ} 16^{\prime} \mathrm{E} \text { (WAM S77963); } \\
28^{\circ} 22^{\prime} \mathrm{S}, 113^{\circ} 54^{\prime} \mathrm{E} \text { (WAM S78325) }\end{array}$ \\
\hline 3 & A. dianthinum & $\begin{array}{l}\text { Scott Reef, } \\
1^{\circ} 02.526^{\prime} \mathrm{S}, 121^{\circ} 45.688^{\prime} \mathrm{E} \text { (WAM S31136) }\end{array}$ & $\begin{array}{l}\text { Ashmore Reef, } \\
12^{\circ} 12^{\prime} \mathrm{S}, 12^{\circ} 123^{\circ} 09^{\prime} \mathrm{E} \text { (WAM S91668); } \\
\text { Vulcan Shoal, } \\
12^{\circ} 48^{\prime} \mathrm{S}, 124^{\circ} 16^{\prime} \mathrm{E} \text { (WAM S91854, Figures 12C-F) }\end{array}$ \\
\hline 4 & A. extremattenuatum sp. nov. & $\begin{array}{l}\text { Ningaloo, } \\
21^{\circ} 49.876^{\prime} \mathrm{S}, 113^{\circ} 58.407^{\prime} \mathrm{E} \text { (WAM S84455) }\end{array}$ & $\begin{array}{l}\text { Lagrange Bay, } \\
18^{\circ} 39^{\prime} \mathrm{S}, 121^{\circ} 42^{\prime} \mathrm{E} \text { (WAM S56792) }\end{array}$ \\
\hline 5 & A. impolitum & $\begin{array}{l}\text { Houtman Abrolhos Islands, } \\
28^{\circ} 24^{\prime} \mathrm{S}, 113^{\circ} 45^{\prime} \mathrm{E} \text { (WAM S79330); } \\
28^{\circ} 50^{\prime} \mathrm{S}, 113^{\circ} 50^{\prime} \mathrm{E} \text { (WAM S15704) }\end{array}$ & $\begin{array}{l}\text { Joseph Bonaparte Gulf, } \\
12^{\circ} 44^{\prime} \mathrm{S}, 128^{\circ} 52^{\prime} \mathrm{E} \text { (NTM P.49882) }\end{array}$ \\
\hline 6 & A. marielae & $\begin{array}{l}\text { Bald Island, } \\
35.1784^{\circ} \mathrm{S}, 118.6320^{\circ} \mathrm{E}(\mathrm{WAM} \mathrm{S} 29282)\end{array}$ & $\begin{array}{l}\text { Ningaloo, } \\
22.0795^{\circ} \mathrm{S}, 113.7960^{\circ} \mathrm{E}(\mathrm{WAM} \mathrm{S} 29299)\end{array}$ \\
\hline 7 & A. punctolineatum & $\begin{array}{l}\text { Mermaid Reef, } \\
17^{\circ} 46^{\prime} \mathrm{S}, 120^{\circ} 43^{\prime} \mathrm{E} \text { (WAM S32858) }\end{array}$ & $\begin{array}{l}\text { Cassini Island, } \\
13^{\circ} 57^{\prime} \mathrm{S}, 125^{\circ} 39^{\prime} \mathrm{E} \text { (WAM S58854); } \\
\text { Long Reef, } \\
14^{\circ} 01^{\prime} \mathrm{S}, 125^{\circ} 44^{\prime} \mathrm{E} \text { (WAM S56960) }\end{array}$ \\
\hline 8 & A. simplex & $\begin{array}{l}\text { Montebello Islands, } \\
20^{\circ} 30^{\prime} \mathrm{S}, 115^{\circ} 32^{\prime} \mathrm{E} \text { (WAM S78358, Figures 12U-X) }\end{array}$ & $\begin{array}{l}\text { Cartier Island, } \\
12^{\circ} 32^{\prime} \mathrm{S}, 123^{\circ} 34^{\prime} \mathrm{E}(\mathrm{TP} 1339)\end{array}$ \\
\hline 9 & A. suduirauti & $\begin{array}{l}\text { Imperieuse Reef, } \\
17^{\circ} 36^{\prime} \mathrm{S}, 118^{\circ} 59^{\prime} \mathrm{E} \text { (WAM S32883, Figures 12O-R) }\end{array}$ & - \\
\hline 10 & A. transcendens & $\begin{array}{l}\text { Ningaloo, } \\
22^{\circ} 06^{\prime} \mathrm{S}, 113^{\circ} 49^{\prime} \mathrm{E} \text { (WAM S43902) }\end{array}$ & $\begin{array}{l}\text { Troughton Island, } \\
13^{\circ} 57^{\prime} \mathrm{S}, 125^{\circ} 52^{\prime} \mathrm{E} \text { (WAM S56894) }\end{array}$ \\
\hline 11 & A. variegatum & $\begin{array}{l}\text { Ningaloo, } \\
22^{\circ} 46^{\prime} 15^{\prime \prime S}, 113^{\circ} 38^{\prime} 4^{\prime \prime} \mathrm{E} \text { (WAM S43505, Figures 12S-T) }\end{array}$ & $\begin{array}{l}\text { Ashmore Reef, } \\
12^{\circ} 12^{\prime} \mathrm{S}, 123^{\circ} 03^{\prime} \mathrm{E} \text { (WAM S75354) }\end{array}$ \\
\hline 12 & Afrocardium richardi & $\begin{array}{l}\text { North West Cape, } \\
21^{\circ} 50^{\prime} \mathrm{S}, 113^{\circ} 46^{\prime} \mathrm{E} \text { (WAM S15920, Figures } 7 \text { A-B) }\end{array}$ & $\begin{array}{l}\text { Broome, } \\
17^{\circ} 58^{\prime} \mathrm{S}, 122^{\circ} 14^{\prime} \mathrm{E} \text { (WAM S57165, Figures 7C-D) }\end{array}$ \\
\hline 13 & Corculum cardissa & $\begin{array}{l}\text { Imperieuse Reef, } 17^{\circ} 30^{\prime} \mathrm{S}, 118^{\circ} 57^{\prime} \mathrm{E} \\
\text { (WAM S68277); } \\
\text { Clerke Reef, } \\
17^{\circ} 22^{\prime} \mathrm{S}, 119^{\circ} 21^{\prime} \mathrm{E} \text { (WAM S39931) }\end{array}$ & $\begin{array}{l}\text { Cartier Island, } \\
12^{\circ} 32^{\prime} \mathrm{S}, 123^{\circ} 33^{\prime} \text { E (NTM P.222, Figures 9M-P) }\end{array}$ \\
\hline 14 & Ctenocardia fornicata & $\begin{array}{l}\text { Scott Reef, } \\
13^{\circ} 59^{\prime} \text { S, 121 } 46^{\prime} \text { E (WAM S39930, Figures 8P-T) }\end{array}$ & - \\
\hline 15 & C. gustavi & $\begin{array}{l}\text { Scott Reef, } \\
13^{\circ} 58^{\prime} \mathrm{S}, 121^{\circ} 51^{\prime} \mathrm{E} \text { (WAM S39929, Figures 9C-D) }\end{array}$ & $\begin{array}{l}\text { Hibernia Reef, } \\
11^{\circ} 58^{\prime} \mathrm{S}, 123^{\circ} 22^{\prime} \mathrm{E} \text { (NTM P.13187); } \\
11^{\circ} 59^{\prime} \mathrm{S}, 123^{\circ} 22^{\prime} \mathrm{E} \text { (NTM P.23197) }\end{array}$ \\
\hline 16 & C. pilbaraensis sp. nov. & $\begin{array}{l}\text { W. of Shark Bay, } \\
25^{\circ} 51^{\prime} \mathrm{S}, 113^{\circ} 03^{\prime} \mathrm{E} \text { (WAM S78046) }\end{array}$ & $\begin{array}{l}\text { Lacepede Island, } \\
16^{\circ} 52^{\prime} \mathrm{S}, 122^{\circ} 09^{\prime} \mathrm{E} \text { (WAM S57168) }\end{array}$ \\
\hline 17 & C. virgo & $\begin{array}{l}\text { Houtman Abrolhos Islands, } \\
28^{\circ} 49^{\prime} \mathrm{S}, 113^{\circ} 47^{\prime} \mathrm{E} \text { (WAM S66883) }\end{array}$ & $\begin{array}{l}\text { Troughton Island, } \\
13^{\circ} 15^{\prime} \mathrm{S}, 128^{\circ} 19^{\prime} \mathrm{E} \text { (WAM S57003) }\end{array}$ \\
\hline 18 & Fragum erugatum & $\begin{array}{l}\text { Point Peron, } \\
32^{\circ} 16^{\prime} \mathrm{S}, 115^{\circ} 41^{\prime} \mathrm{E} \text { (WAM S66925) }\end{array}$ & $\begin{array}{l}\text { Dampier Archipelago, } \\
20^{\circ} 29^{\prime} \mathrm{S}, 116^{\circ} 52^{\prime} \mathrm{E} \text { (WAM S18229; WAM } \\
\text { S18232); } 20^{\circ} 23.98^{\prime} \mathrm{S}, 116^{\circ} 49.52^{\prime} \mathrm{E} \text { (WAM S18245) }\end{array}$ \\
\hline 19 & Fragum fragum & $\begin{array}{l}\text { Cardabia, } \\
23^{\circ} 06^{\prime} \mathrm{S}, 113^{\circ} 48^{\prime} \mathrm{E} \text { (WAM S79486, ex 2374-67)*; } \\
\text { Warroora Station, } \\
23^{\circ} 29^{\prime} \mathrm{S}, 113^{\circ} 48^{\prime} \mathrm{E} \text { (WAM S79484) }\end{array}$ & $\begin{array}{l}\text { Ashmore Reef, } \\
12^{\circ} 11^{\prime} \mathrm{S}, 122^{\circ} 58^{\prime} \mathrm{E} \text { (WAM S57061); } \\
\text { Hibernia Reef, } \\
11^{\circ} 55^{\prime} \mathrm{S}, 123^{\circ} 28^{\prime} \mathrm{E} \text { (WAM S } 57070 \text { ) }\end{array}$ \\
\hline 20 & F. mundum & $\begin{array}{l}\text { Dampier Archipelago, } \\
20^{\circ} 29^{\prime} \mathrm{S}, 116^{\circ} 32^{\prime} \mathrm{E} \text { (WAM S79509, Figures 10E-H) }\end{array}$ & $\begin{array}{l}\text { Ashmore Reef, } \\
12^{\circ} 17^{\prime} \mathrm{S}, 123^{\circ} 08^{\prime} \mathrm{E} \text { (WAM S75212, Figures 10A-D); } \\
\text { Cartier Island, } \\
12^{\circ} 32^{\prime} \mathrm{S}, 123^{\circ} 34^{\prime} \mathrm{E} \text { (NTM P.54210, Figures 10K-L) }\end{array}$ \\
\hline
\end{tabular}




\begin{tabular}{|c|c|c|c|}
\hline No. & Species & WA S./E. end of distribution & WA N./E. end of distribution \\
\hline 21 & F. sp. aff. scruposum & $\begin{array}{l}\text { Houtman Abrolhos Islands, } \\
28^{\circ} 26^{\prime} \mathrm{S}, 113^{\circ} 43^{\prime} \mathrm{E} \text { (WAM S78123, Figures 10M-N) }\end{array}$ & - \\
\hline 22 & F. sueziense & $\begin{array}{l}\text { Houtman Abrolhos Islands, } \\
28^{\circ} 42^{\prime} \mathrm{S}, 113^{\circ} 46.5^{\prime} \mathrm{E} \text { (WAM S84480) }\end{array}$ & $\begin{array}{l}\text { Broome, } \\
17^{\circ} 58^{\prime} \mathrm{S}, 122^{\circ} 14^{\prime} \mathrm{E} \text { (WAM S57164) }\end{array}$ \\
\hline 23 & F. unedo & $\begin{array}{l}\text { Shark Bay, } \\
26^{\circ} 13^{\prime} \mathrm{S}, 113^{\circ} 41^{\prime} \mathrm{E} \text { (WAM S79603) }\end{array}$ & $\begin{array}{l}\text { Sir Graham Moore Islands, } \\
13^{\circ} 52^{\prime} \mathrm{S}, 126^{\circ} 36^{\prime} \mathrm{E} \text { (WAM S57047) }\end{array}$ \\
\hline \multirow[t]{2}{*}{24} & F. whitleyi & $\begin{array}{l}\text { Houtman Abrolhos Islands, } \\
28^{\circ} 42^{\prime} \mathrm{S}, 113^{\circ} 46^{\prime} \mathrm{E} \text { (WAM S133366) }\end{array}$ & $\begin{array}{l}\text { Ashmore Reef, } \\
12^{\circ} 17^{\prime} \mathrm{S}, 123^{\circ} 08^{\prime} \mathrm{E} \text { (WAM S91688, Figures 10P-Q); }\end{array}$ \\
\hline & & $\begin{array}{l}\text { Dampier Archipelago, } \\
20^{\circ} 29^{\prime} \mathrm{S}, 116^{\circ} 35^{\prime} \mathrm{E} \text { (WAM S13359) }\end{array}$ & $\begin{array}{l}\text { Ashmore Reef, } \\
12^{\circ} 16^{\prime} \mathrm{S}, 123^{\circ} 06^{\prime} \mathrm{E}(\mathrm{WAM} \mathrm{S} 84271)\end{array}$ \\
\hline 25 & Freneixicardia victor & $\begin{array}{l}\text { Ningaloo, } \\
22^{\circ} 10.661^{\prime} \mathrm{S}, 113^{\circ} 48.9377^{\prime} \mathrm{E} \text { (WAM S79726); } \\
22^{\circ} 10.156^{\prime} \mathrm{S}, 113^{\circ} 50.282^{\prime} \mathrm{E} \text { (WAM S79727) }\end{array}$ & $\begin{array}{l}\text { Adele Island, } \\
1^{\circ} 34^{\prime} \mathrm{S}, 122^{\circ} 55^{\prime} \mathrm{E} \text { (WAM S32874) }\end{array}$ \\
\hline 26 & Frigidocardium eos & $\begin{array}{l}\text { Bunbury, } \\
33^{\circ} 00^{\prime} \mathrm{S}, 114^{\circ} 52^{\prime} \mathrm{E} \text { (WAM S84345, Figures 2E-F); } \\
\text { Point Cloates, } \\
22^{\circ} 52^{\prime} \mathrm{S}, 113^{\circ} 29^{\prime} \mathrm{E} \text { (WAM S15917, Figures 2A-D) }\end{array}$ & $\begin{array}{l}\text { Kulumburu, } \\
13^{\circ} 28^{\prime} \mathrm{S}, 124^{\circ} 01^{\prime} \mathrm{E} \text { (WAM S32879) }\end{array}$ \\
\hline 27 & F. helios & $\begin{array}{l}\text { Point Cloates, } \\
22.8487^{\circ} \mathrm{S}, 113.5110^{\circ} \mathrm{E}(\mathrm{WAM} \mathrm{S} 29441)\end{array}$ & $\begin{array}{l}\text { Onslow, } \\
21^{\circ} 31^{\prime} \mathrm{S}, 114^{\circ} 40^{\prime} \mathrm{E} \text { (WAM S78145, Figures 3A-B) }\end{array}$ \\
\hline 28 & F. iris & $\begin{array}{l}\text { Ningaloo, } \\
22^{\circ} 15^{\prime} 46^{\prime \prime} \mathrm{S}, 113^{\circ} 44^{\prime} 58^{\prime \prime} \mathrm{E} \text { (WAM S78135) }\end{array}$ & $\begin{array}{l}\text { W. of Cartier Island, } \\
12^{\circ} 43^{\prime} \mathrm{S}, 123^{\circ} 58^{\prime} \mathrm{E} \text { (NTM P.8600) }\end{array}$ \\
\hline 29 & F. torresi & $\begin{array}{l}\text { Dampier Archipelago, } \\
19^{\circ} 23^{\prime} \mathrm{S}, 117^{\circ} 21^{\prime} \mathrm{E} \text { (WAM S78287) }\end{array}$ & $\begin{array}{l}\text { Broome, } \\
17^{\circ} 58^{\prime} \mathrm{S}, 122^{\circ} 14^{\prime} \mathrm{E} \text { (WAM S57167); } \\
\text { Clerke Reef, } \\
1^{\circ} 20^{\prime} \mathrm{S}, 119^{\circ} 10^{\prime} \mathrm{E} \text { (WAM S15913; WAM S15915) }\end{array}$ \\
\hline 30 & Fulvia aperta & $\begin{array}{l}\text { Point Cloates, } \\
22^{\circ} 37^{\prime} \mathrm{S}, 113^{\circ} 38.5^{\prime} \mathrm{E} \text { (WAM S84240) }\end{array}$ & $\begin{array}{l}\text { Mission Bay, } \\
14^{\circ} 06^{\prime} \mathrm{S}, 126^{\circ} 42^{\prime} \mathrm{E} \text { (WAM S56823) }\end{array}$ \\
\hline 31 & F. australis & $\begin{array}{l}\text { S. of Ningaloo, } \\
24^{\circ} 00.9114^{\prime} S, 113^{\circ} 26.4864^{\prime} \mathrm{E} \text { (WAM S84236) }\end{array}$ & $\begin{array}{l}\text { Malcolm Island, } \\
14^{\circ} 31^{\prime} \mathrm{S}, 125^{\circ} 54^{\prime} \mathrm{E} \text { (WAM S66929) }\end{array}$ \\
\hline 32 & F. boholensis & $\begin{array}{l}\text { Dampier Archipelago, } \\
20^{\circ} 42.42^{\prime} \mathrm{S}, 116^{\circ} 30.31^{\prime} \mathrm{E} \text { (NTM P.54198, Figures 11G-J) }\end{array}$ & - \\
\hline 33 & F. laevigata & $\begin{array}{l}\text { Shark Bay, } \\
26^{\circ} 09^{\prime} \mathrm{S}, 113^{\circ} 09^{\prime} \mathrm{E} \text { (WAM S66948) } \\
\text { Shark Bay, Monkey Mia } \\
\text { (ZMA.MOLL.80911) }\end{array}$ & $\begin{array}{l}\text { Tranquil Bay, } \\
13^{\circ} 56^{\prime} \mathrm{S}, 127^{\circ} 18^{\prime} \mathrm{E} \text { (WAM S56805) }\end{array}$ \\
\hline 34 & F. scalata & $18^{\circ} 47^{\prime} \mathrm{S}, 117^{\circ} 58^{\prime} \mathrm{E}$ (WAM S56827, WAM S57158) & $\begin{array}{l}\text { Mermaid Reef, } \\
17^{\circ} 29^{\prime} \mathrm{S}, 120^{\circ} 28^{\prime} \mathrm{E} \text { (WAM S34673, Figures 11P-S) }\end{array}$ \\
\hline 35 & F. tenuicostata & $\begin{array}{l}\text { Esperance, } \\
33^{\circ} 52^{\prime} \mathrm{S}, 121^{\circ} 54^{\prime} \mathrm{E} \text { (WAM S66932) }\end{array}$ & $\begin{array}{l}\text { Houtman Abrolhos Islands, } \\
28^{\circ} 43^{\prime} \mathrm{S}, 113^{\circ} 47^{\prime} \mathrm{E} \text { (WAM S82989) }\end{array}$ \\
\hline 36 & F. undatopicta & $\begin{array}{l}\text { Muiron Islands, } \\
21^{\circ} 41^{\prime} \mathrm{S}, 114^{\circ} 31^{\prime} \mathrm{E} \text { (WAM S78338, Figures } 11 \mathrm{~V}-\mathbf{Y} \text { ) }\end{array}$ & $\begin{array}{l}\text { Broome, } \\
17^{\circ} 58^{\prime} \mathrm{S}, 122^{\circ} 14^{\prime} \mathrm{E} \text { (WAM S57166) }\end{array}$ \\
\hline 37 & Lunulicardia tumorifera & $\begin{array}{l}\text { Shark Bay, } \\
26^{\circ} 13^{\prime} \mathrm{S}, 113^{\circ} 47^{\prime} \mathrm{E} \text { (WAM S66835) }\end{array}$ & $\begin{array}{l}\text { Exmouth Gulf, } \\
22^{\circ} 27^{\prime} \mathrm{S}, 114^{\circ} 20^{\prime} \mathrm{E} \text { (WAM S66834); } \\
\text { Point Cloates, } \\
22^{\circ} 37^{\prime} \mathrm{S}, 113^{\circ} 38.5^{\prime} \mathrm{E} \text { (WAM S66837) }\end{array}$ \\
\hline 38 & L. retusa & $\begin{array}{l}\text { Cockburn Sound, } \\
32^{\circ} 13^{\prime} \mathrm{S}, 115^{\circ} 42^{\prime} \mathrm{E} \text { (WAM S66915) }\end{array}$ & $\begin{array}{l}\text { Vansittart Bay, } \\
14^{\circ} 04^{\prime} \mathrm{S}, 126^{\circ} 20^{\prime} \mathrm{E} \text { (WAM S57050); } \\
14^{\circ} 02^{\prime} \mathrm{S}, 126^{\circ} 18^{\prime} \mathrm{E} \text { (WAM S57075) }\end{array}$ \\
\hline 39 & Lyrocardium aurantiacum & $\begin{array}{l}\text { Ningaloo, } \\
22^{\circ} 18.263^{\prime} \mathrm{S}, 113^{\circ} 46.544^{\prime} \mathrm{E} \text { (WAM S78132) }\end{array}$ & $\begin{array}{l}\text { Dampier Archipelago, } \\
19^{\circ} 55^{\prime} \mathrm{S}, 116^{\circ} 36^{\prime} \mathrm{E} \text { (WAM S78055, Figures } 7 \mathbf{L}-\mathbf{M} \text { ) }\end{array}$ \\
\hline 40 & L. lyratum & $\begin{array}{l}\text { Houtman Abrolhos Islands, } \\
28^{\circ} 49^{\prime} \mathrm{S}, 113^{\circ} 47^{\prime} \mathrm{E} \text { (WAM S66936) }\end{array}$ & $\begin{array}{l}\text { Institut Islands, } \\
13^{\circ} 56^{\prime} \mathrm{S}, 125^{\circ} 38^{\prime} \mathrm{E} \text { (WAM S57098); } \\
13^{\circ} 56^{\prime} \mathrm{S}, 125^{\circ} 39^{\prime} \mathrm{E} \text { (WAM S57099; WAM S57100) }\end{array}$ \\
\hline 41 & Maoricardium fraseri & $\begin{array}{l}\text { N. of Cape Lambert, } \\
20^{\circ} 01^{\prime} \mathrm{S}, 117^{\circ} 13^{\prime} \mathrm{E} \text { (WAM S66941) }\end{array}$ & $\begin{array}{l}\text { N.E. of Adele Island, } \\
14^{\circ} 52^{\prime} \mathrm{S}, 123^{\circ} 52^{\prime} \mathrm{E} \text { (WAM S56801) }\end{array}$ \\
\hline 42 & M. setosum & $\begin{array}{l}\text { Exmouth Gulf, } \\
22^{\circ} 18^{\prime} \mathrm{S}, 114^{\circ} 08^{\prime} \mathrm{E} \text { (WAM S66944, ex 70-67)* }\end{array}$ & $\begin{array}{l}\text { Joseph Bonaparte Gulf, } \\
14^{\circ} 34^{\prime} \mathrm{S}, 128^{\circ} 27^{\prime} \mathrm{E} \text { (WAM S57143); }\end{array}$ \\
\hline & & & $\begin{array}{l}\text { W. of Troughton Island, } \\
13^{\circ} 57^{\prime} \mathrm{S}, 125^{\circ} 52^{\prime} \mathrm{E} \text { (WAM S56783) }\end{array}$ \\
\hline 43 & Microcardium sakuraii & $\begin{array}{l}\text { Mermaid Reef, } \\
17^{\circ} 12^{\prime} \mathrm{S}, 119^{\circ} 35^{\prime} \mathrm{E} \text { (WAM S32885) }\end{array}$ & $\begin{array}{l}\text { Augustus Island, } \\
13^{\circ} 33.3^{\prime} \mathrm{S}, 122^{\circ} 54.5^{\prime} \mathrm{E} \text { (WAM S57163); }\end{array}$ \\
\hline & & & $\begin{array}{l}\text { Browse Island, } \\
14^{\circ} 06^{\prime} \mathrm{S}, 123^{\circ} 33^{\prime} \mathrm{E} \text { (WAM S57142) }\end{array}$ \\
\hline 44 & M. scabrosum sp. nov. & $\begin{array}{l}\text { Ningaloo, } \\
22.0795^{\circ} \mathrm{S}, 113.7960^{\circ} \mathrm{E}(\mathrm{WAM} \mathrm{S} 29448)\end{array}$ & $\begin{array}{l}\text { N.W. of Port Hedland, } \\
18^{\circ} 47^{\prime} \text { S, } 117^{\circ} 58^{\prime} \text { E (WAM S15906, Figures 3I-J) }\end{array}$ \\
\hline
\end{tabular}




\begin{tabular}{|c|c|c|c|}
\hline No. & Species & WA S./E. end of distribution & WA N./E. end of distribution \\
\hline 45 & Microfragum festivum & $\begin{array}{l}\text { Clerke Reef, } \\
17^{\circ} 20^{\prime} \mathrm{S}, 119^{\circ} 20^{\prime} \mathrm{E} \text { (NTM P.40065); } \\
17^{\circ} 16^{\prime} \mathrm{S}, 19^{\circ} 22^{\prime} \mathrm{E} \text { (WAM S40376, Figures 9E-H) }\end{array}$ & $\begin{array}{l}\text { Ashmore Reef, } 12^{\circ} 13^{\prime} \mathrm{S}, 122^{\circ} 58^{\prime} \mathrm{E} \text { (NTM } \\
\text { P.24387) }\end{array}$ \\
\hline 46 & Nemocardium probatum & $\begin{array}{l}\text { Lancelin, } 30^{\circ} 58^{\prime} \mathrm{S}, 114^{\circ} 49^{\prime} \mathrm{E} \text { (WAM S78233); } \\
\text { S. of Houtman Abrolhos Islands, } \\
29^{\circ} 08^{\prime} \mathrm{S}, 113^{\circ} 57^{\prime} \mathrm{E} \text { (WAM S66934) }\end{array}$ & $\begin{array}{l}\text { N.E. of Troughton Island, } \\
13^{\circ} 12^{\prime} \mathrm{S}, 128^{\circ} 37^{\prime} \mathrm{E} \text { (WAM S56998) }\end{array}$ \\
\hline 47 & $\begin{array}{l}\text { Pratulum occidentale sp. } \\
\text { nov. }\end{array}$ & $\begin{array}{l}\text { N. of Bluff Point, } \\
27^{\circ} 18^{\prime} \mathrm{S}, 113^{\circ} 16^{\prime} \mathrm{E} \text { (WAM S15916, Figures 6A-B; } \\
\text { WAM S70653) }\end{array}$ & $\begin{array}{l}\text { N.W. of Cape Leveque, } \\
15^{\circ} 12^{\prime} \mathrm{S}, 121^{\circ} 26^{\prime} \mathrm{E} \text { (WAM S34674) }\end{array}$ \\
\hline 48 & P. thetidis & $\begin{array}{l}\text { Esperance Bay, } \\
33^{\circ} 52^{\prime} \mathrm{S}, 121^{\circ} 54^{\prime} \mathrm{E}(\mathrm{WAM} \mathrm{S} 84264)\end{array}$ & $\begin{array}{l}\text { W. of Cliff Head, } \\
29^{\circ} 32^{\prime} \mathrm{S}, 114^{\circ} 16^{\prime} \mathrm{E} \text { (WAM S15919) }\end{array}$ \\
\hline 49 & 'Laevicardium' lobulatum & $\begin{array}{l}\text { Clerke Reef, } \\
\left.17^{\circ} 18^{\prime} \mathrm{S}, 119^{\circ} 22^{\prime} \mathrm{E} \text { (WAM S68164, Figures } 7 \mathbf{N}-\mathbf{Q}\right)\end{array}$ & - \\
\hline 50 & Trifaricardium morrisoni & $\begin{array}{l}\text { N.W. of Port Hedland, } \\
18^{\circ} 47^{\prime} \mathrm{S}, 117^{\circ} 58^{\prime} \mathrm{E} \text { (WAM S15903, paratype) }\end{array}$ & $\begin{array}{l}\text { Cape Leveque, } \\
14^{\circ} 52.2^{\prime} \mathrm{S}, 121^{\circ} 41.7^{\prime} \mathrm{E} \text { (WAM S15911, paratype) }\end{array}$ \\
\hline 51 & T. nomurai & $\begin{array}{l}\text { Rowley Shoals, } \\
1^{\circ} 20^{\prime} \mathrm{S}, 119^{\circ} 10^{\prime} \mathrm{E} \text { (WAM S29459, Figure 7S; } \\
\text { WAM S39961, Figures } 7 \text { T-U) }\end{array}$ & - \\
\hline 52 & Vasticardium angulatum & $\begin{array}{l}\text { Exmouth Gulf, } \\
21^{\circ} 53^{\prime} \mathrm{S}, 114^{\circ} 09^{\prime} \mathrm{E} \text { (WAM S84324) }\end{array}$ & $\begin{array}{l}\text { Reveley Island, } \\
14^{\circ} 22^{\prime} \mathrm{S}, 127^{\circ} 50^{\prime} \mathrm{E} \text { (WAM S84354) }\end{array}$ \\
\hline 53 & $V$. dupuchense & $\begin{array}{l}\text { Carnarvon, } \\
23^{\circ} 29^{\prime} \mathrm{S}, 113^{\circ} 48^{\prime} \mathrm{E} \text { (WAM S84362) }\end{array}$ & $\begin{array}{l}\text { Broome, } \\
17^{\circ} 58^{\prime} \mathrm{S}, 122^{\circ} 14^{\prime} \mathrm{E} \text { (WAM S56906; WAM } \\
\text { S56907) }\end{array}$ \\
\hline 54 & V. elongatum & $\begin{array}{l}\text { Ashmore Reef, } \\
\left.12^{\circ} 11^{\prime} \mathrm{S}, 122^{\circ} 58^{\prime} \mathrm{E} \text { (WAM S56890, Figures } \mathbf{1 5 A}-\mathbf{B}\right) \text {; } \\
12^{\circ} 11^{\prime} \mathrm{S}, 123^{\circ} 03^{\prime} \mathrm{E} \text { (WAM S75817) }\end{array}$ & - \\
\hline 55 & $V$. fultoni & $\begin{array}{l}\text { Point Cloates, } \\
22^{\circ} 30^{\prime} \mathrm{S}, 113^{\circ} 42^{\prime} \mathrm{E} \text { (WAM S82974); } \\
22^{\circ} 29^{\prime} \mathrm{S}, 113^{\circ} 42^{\prime} \mathrm{E} \text { (WAM S84469) }\end{array}$ & $\begin{array}{l}\text { Tranquil Bay, } \\
13^{\circ} 56^{\prime} \mathrm{S}, 127^{\circ} 18^{\prime} \mathrm{E} \text { (WAM S56902) }\end{array}$ \\
\hline 56 & $V$. mindanense & $\begin{array}{l}\text { Ashmore Reef, } \\
12^{\circ} 14^{\prime} \text { S, } 122^{\circ} 58^{\prime} \text { E (NTM P.10066, Figures 15C-E) }\end{array}$ & - \\
\hline 57 & $V$. philippinense & $\begin{array}{l}\text { Imperieuse Reef, } \\
17^{\circ} 32^{\prime} \mathrm{S}, 118^{\circ} 58^{\prime} \mathrm{E} \text { (WAM S68174) }\end{array}$ & $\begin{array}{l}\text { Martin Shoal, } \\
9^{\circ} 37^{\prime} \mathrm{S}, 128^{\circ} 53^{\prime} \mathrm{E} \text { (NTM P.55827) }\end{array}$ \\
\hline 58 & $V$. sewelli & $\begin{array}{l}\text { Martin Shoal, } \\
9^{\circ} 36.64^{\prime} \mathrm{S}, 128^{\circ} 52.6^{\prime} \mathrm{E}(\mathrm{TP} 4679 \text {, Figures 16A-D) }\end{array}$ & - \\
\hline 59 & V. vertebratum & $\begin{array}{l}\text { Dunsborough, } \\
33^{\circ} 37^{\prime} \mathrm{S}, 115^{\circ} 06^{\prime} \mathrm{E} \text { (WAM S84473, ex N-2357)* }\end{array}$ & $\begin{array}{l}\text { Tranquil Bay, } \\
13^{\circ} 56^{\prime} \mathrm{S}, 127^{\circ} 18^{\prime} \mathrm{E} \text { (WAM S56850) }\end{array}$ \\
\hline 60 & V. wilsoni & $\begin{array}{l}\text { Ningaloo, } \\
22^{\circ} 48^{\prime} \mathrm{S}, 113^{\circ} 32^{\prime} \mathrm{E} \text { (WAM S43904) }\end{array}$ & $\begin{array}{l}\text { Heritage Reef, } \\
14^{\circ} 15^{\prime} \mathrm{S}, 125^{\circ} 09^{\prime} \mathrm{E} \text { (WAM S56891); } \\
\text { Institut Islands, } \\
13^{\circ} 56^{\prime} \mathrm{S}, 125^{\circ} 37^{\prime} \mathrm{E} \text { (WAM S57107) }\end{array}$ \\
\hline 61 & Vepricardium multispinosum & $\begin{array}{l}\text { S. of Ningaloo, } \\
23^{\circ} 28^{\prime} \mathrm{S}, 113^{\circ} 47^{\prime} \mathrm{E} \text { (WAM S84272) }\end{array}$ & $\begin{array}{l}\text { Joseph Bonaparte Gulf, } \\
13^{\circ} 04^{\prime} \mathrm{S}, 129^{\circ} 02^{\prime} \mathrm{E} \text { (WAM S56779); } \\
\text { N.E. of Adele Island, } \\
14^{\circ} 52^{\prime} \mathrm{S}, 123^{\circ} 52^{\prime} \mathrm{E} \text { (WAM S56790) }\end{array}$ \\
\hline 62 & Hippopus hippopus & $\begin{array}{l}\text { Clerke Reef, } \\
17^{\circ} 23^{\prime} \mathrm{S}, 119^{\circ} 20^{\prime} \mathrm{E} \text { (WAM S33232); } \\
\text { Imperieuse Reef (WAM field observations, } 2014 \text { trip) }\end{array}$ & $\begin{array}{l}\text { Troughton Island, } \\
13^{\circ} 45^{\prime} \mathrm{S}, 126^{\circ} 11^{\prime} \mathrm{E} \text { (WAM S57187) }\end{array}$ \\
\hline 63 & Tridacna crocea & $\begin{array}{l}\text { Clerke Reef, } \\
17^{\circ} 23^{\prime} \mathrm{S}, 119^{\circ} 20^{\prime} \mathrm{E} \text { (WAM S33251) }\end{array}$ & $\begin{array}{l}\text { Cartier Island, } \\
12^{\circ} 31^{\prime} \mathrm{S}, 123^{\circ} 33^{\prime} \mathrm{E} \text { (WAM S57196; WAM S57234) }\end{array}$ \\
\hline 64 & T. maxima & $\begin{array}{l}\text { Houtman Abrolhos Islands, } \\
28^{\circ} 43^{\prime} \mathrm{S}, 113^{\circ} 47^{\prime} \mathrm{E} \text { (WAM S66949); } \\
28^{\circ} 53^{\prime} \mathrm{S}, 113^{\circ} 51^{\prime} \mathrm{E} \text { (WAM S66951) }\end{array}$ & $\begin{array}{l}\text { Jar Island, } \\
1^{\circ} 09^{\prime} \mathrm{S}, 126^{\circ} 14^{\prime} \mathrm{E} \text { (WAM S57192) }\end{array}$ \\
\hline 65 & T. noae & $\begin{array}{l}\text { Shark Bay, } \\
24^{\circ} 59^{\prime} \mathrm{S}, 113^{\circ} 07^{\prime} \mathrm{E} \text { (WAM S66952) }\end{array}$ & $\begin{array}{l}\text { Montebello Islands, } \\
20^{\circ} 23^{\prime} \mathrm{S}, 115^{\circ} 33^{\prime} \mathrm{E} \text { (WAM S87944) }\end{array}$ \\
\hline 66 & T. squamosa & $\begin{array}{l}\text { Coral Bay, } \\
23^{\circ} 11^{\prime} \mathrm{S}, 113^{\circ} 46^{\prime} \mathrm{E} \text { (NTM P.47918); } \\
\text { Muiron Islands, } \\
21^{\circ} 38^{\prime} \mathrm{S}, 114^{\circ} 24^{\prime} \mathrm{E} \text { (WAM S66954) }\end{array}$ & $\begin{array}{l}\text { Troughton Island, } \\
13^{\circ} 45^{\prime} \mathrm{S}, 126^{\circ} 11^{\prime} \mathrm{E} \text { (WAM S57223) }\end{array}$ \\
\hline 67 & T. derasa & $\begin{array}{l}\text { Mermaid Reef (Bryce and Whisson, 2009); } \\
\text { Imperieuse Reef (WAM field observations, Stn 164) }\end{array}$ & $\begin{array}{l}\text { Ashmore Reef (LK field observations, 2013); } \\
\text { Hibernia Reef (Bryce, field observation) }\end{array}$ \\
\hline 68 & T. gigas & $\begin{array}{l}\text { Clerke Reef, } \\
17^{\circ} 20^{\prime} \mathrm{S}, 119^{\circ} 21^{\prime} \mathrm{E} \text { (WAM S29483); } \\
\text { Imperieuse Reef (WAM field observations, Stn 164) }\end{array}$ & $\begin{array}{l}\text { Hibernia Reef, } \\
11^{\circ} 58^{\prime} \mathrm{S}, 123^{\circ} 19^{\prime} \mathrm{E} \text { (WAM S57197) }\end{array}$ \\
\hline
\end{tabular}



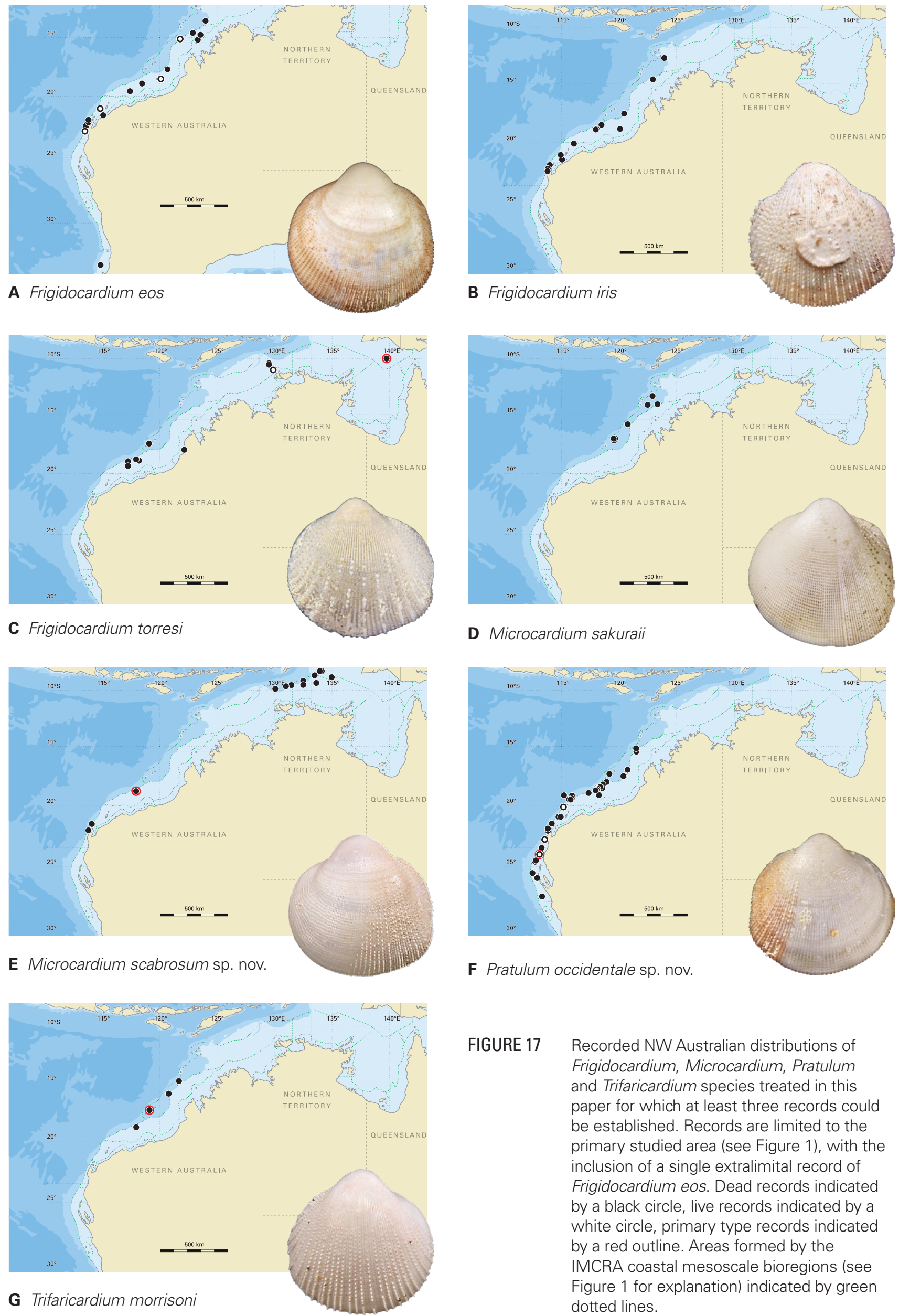

FIGURE 17 Recorded NW Australian distributions of Frigidocardium, Microcardium, Pratulum and Trifaricardium species treated in this paper for which at least three records could be established. Records are limited to the primary studied area (see Figure 1), with the inclusion of a single extralimital record of Frigidocardium eos. Dead records indicated by a black circle, live records indicated by a white circle, primary type records indicated by a red outline. Areas formed by the IMCRA coastal mesoscale bioregions (see Figure 1 for explanation) indicated by green dotted lines. 

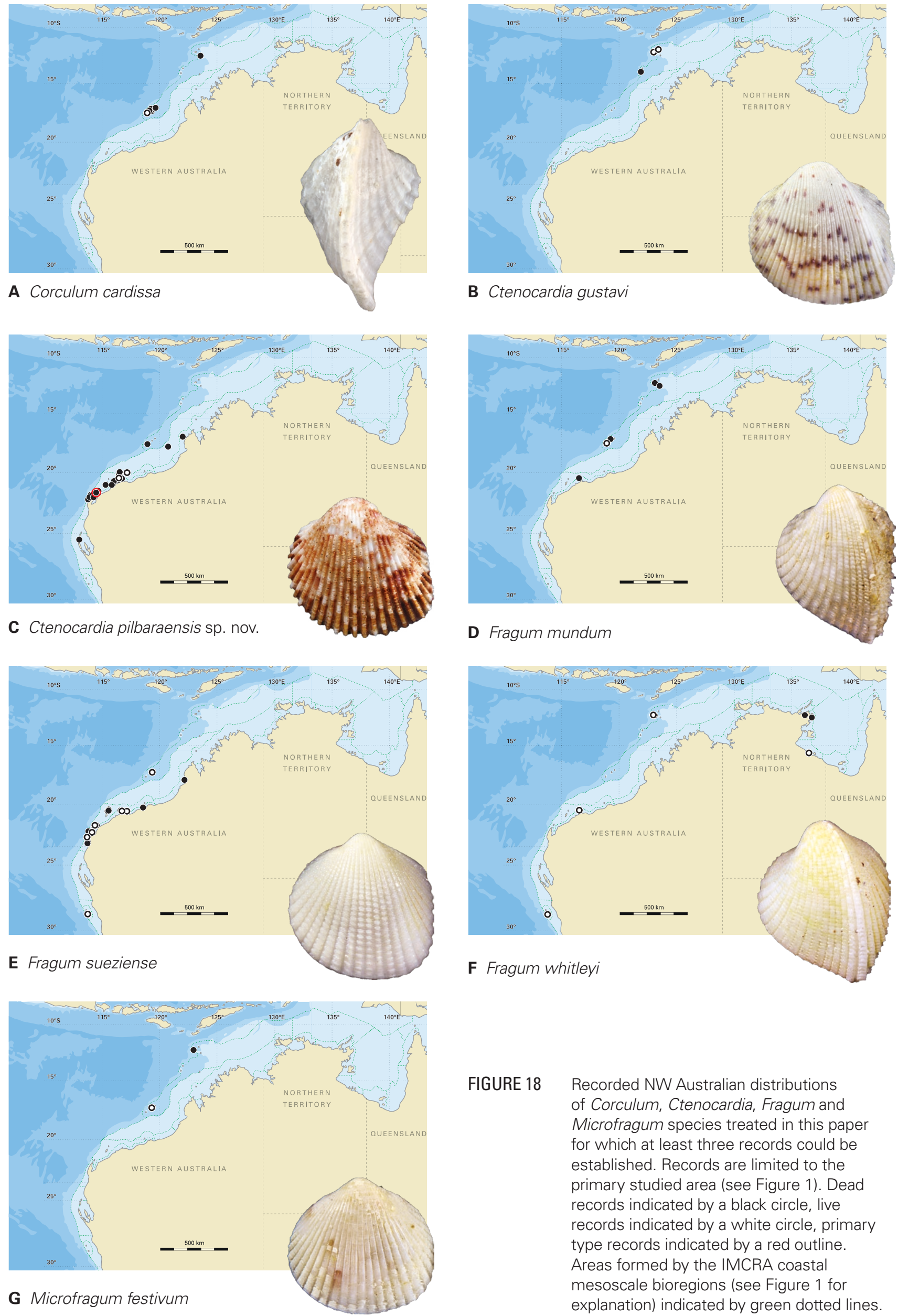

FIGURE 18 Recorded NW Australian distributions of Corculum, Ctenocardia, Fragum and Microfragum species treated in this paper for which at least three records could be established. Records are limited to the primary studied area (see Figure 1). Dead records indicated by a black circle, live records indicated by a white circle, primary type records indicated by a red outline. Areas formed by the IMCRA coastal mesoscale bioregions (see Figure 1 for explanation) indicated by green dotted lines. 

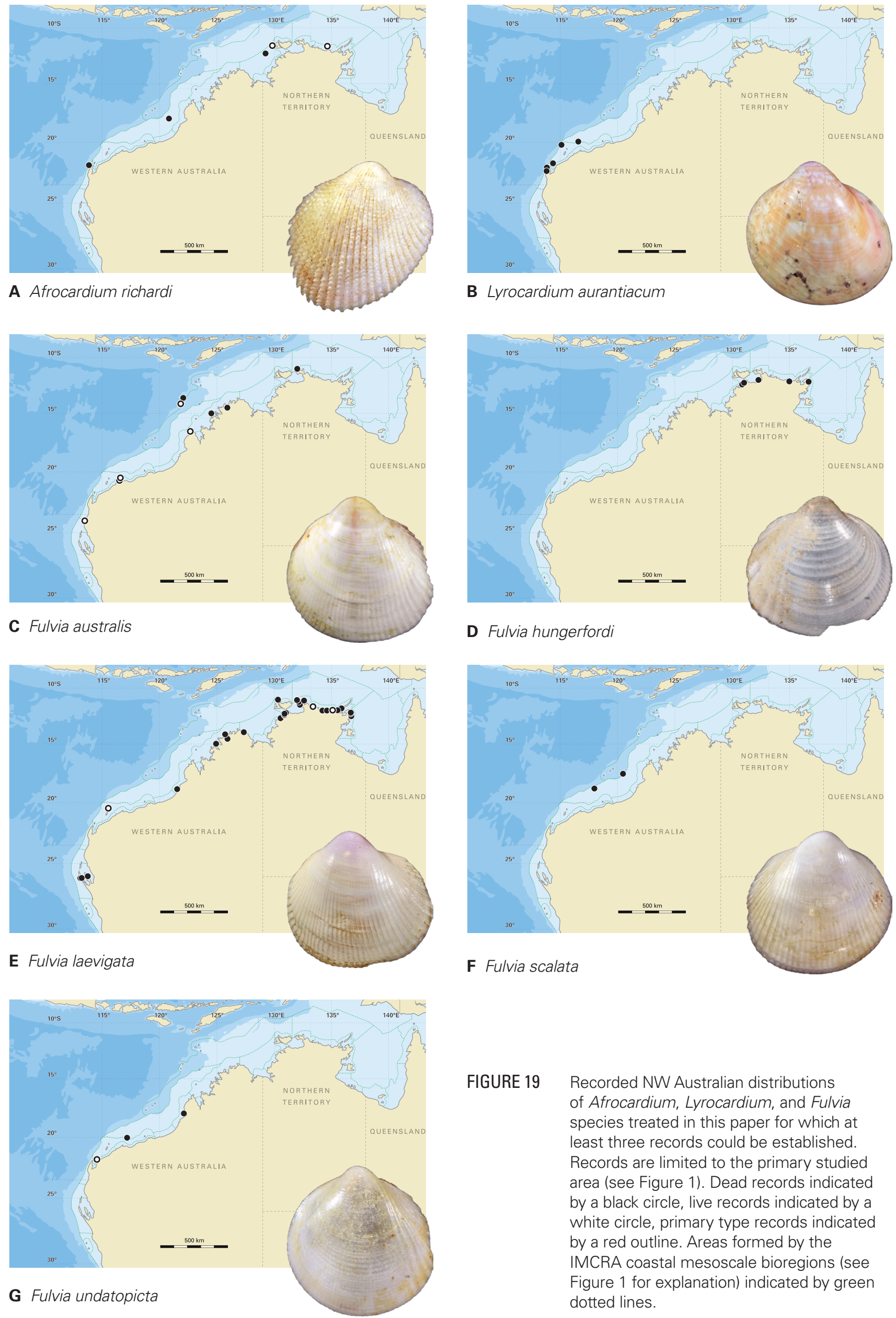

FIGURE 19 Recorded NW Australian distributions of Afrocardium, Lyrocardium, and Fulvia species treated in this paper for which at least three records could be established. Records are limited to the primary studied area (see Figure 1). Dead records indicated by a black circle, live records indicated by a white circle, primary type records indicated by a red outline. Areas formed by the IMCRA coastal mesoscale bioregions (see Figure 1 for explanation) indicated by green dotted lines. 

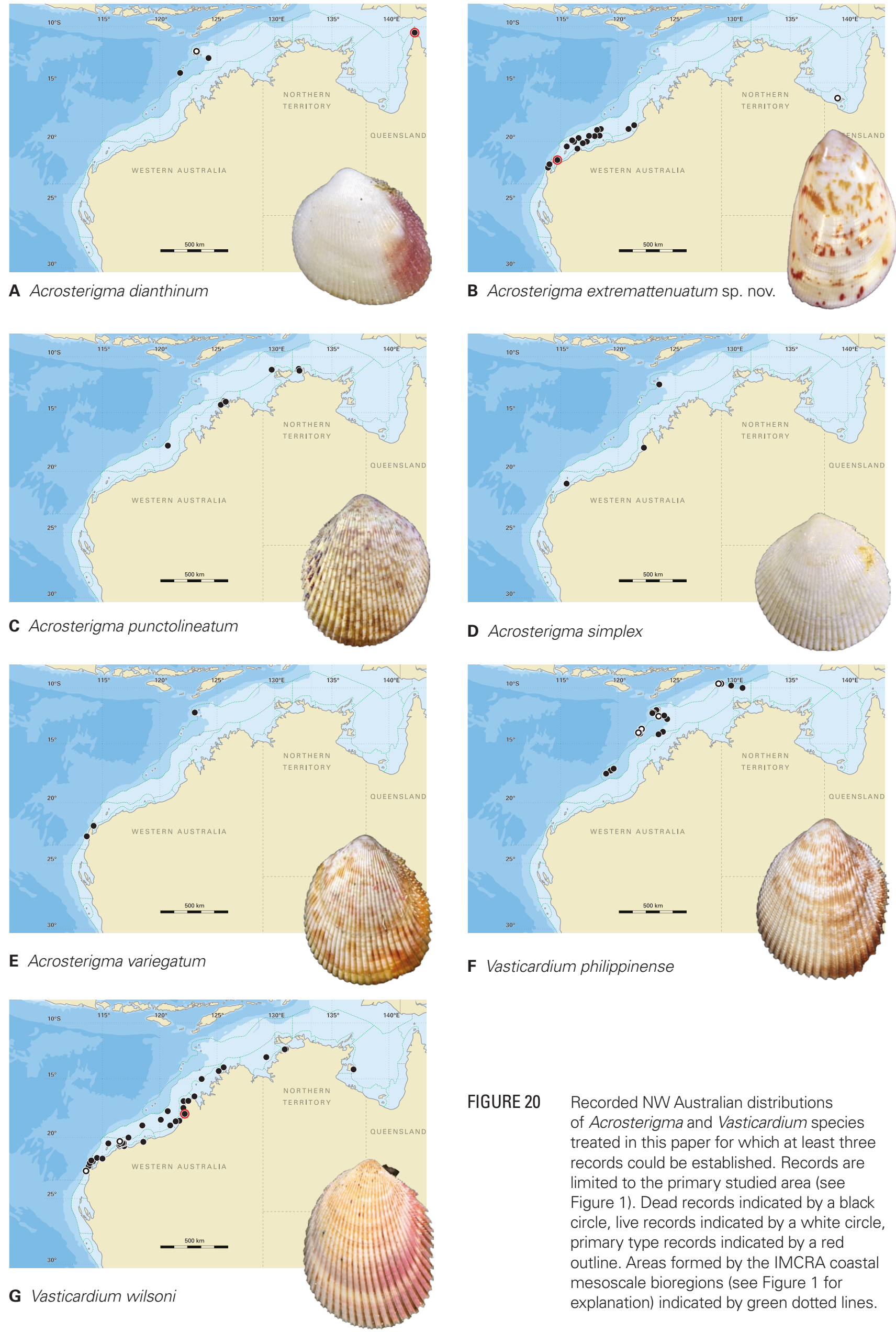

FIGURE 20 Recorded NW Australian distributions of Acrosterigma and Vasticardium species treated in this paper for which at least three records could be established. Records are limited to the primary studied area (see Figure 1). Dead records indicated by a black circle, live records indicated by a white circle, primary type records indicated by a red outline. Areas formed by the IMCRA coastal mesoscale bioregions (see Figure 1 for explanation) indicated by green dotted lines. 


\section{DISCUSSION}

\section{BIODIVERSITY AND TAXONOMY OF WA CARDIIDAE}

The fauna of the northern offshore reefs was hardly known until a series of surveys were undertaken starting in the late 1970s-early 1980s (Berry and Marsh 1986; Morrison and Wells 2005), with the Montebello Islands only sporadically surveyed before 1993 (Wells and Berry 2000). Hence, Wilson and Stevenson (1977) had to base their data almost exclusively on the cardiids of inshore WA, with only one record from the Rowley Shoals and none from the Montebellos. In contrast, the Indonesian Roti Island (located only $145 \mathrm{~km}$ North of Ashmore Reef and separated by the Timor Trough) as well as neighbouring islands, had been visited by the Dutch Siboga Expedition as early as 1900 (Weber-van Bosse 1904). Given this sampling bias, Wilson and Stevenson (1977) nevertheless recognised 31 WA Cardiidae species of which 29 are considered valid today (Table 1). Targeted expeditions to the northern offshore reefs in intervening years have greatly improved diversity estimates at these rich IWP sites, with the number of widespread cardiid species increased from 23 to 52 (and nearly all extending only to the northern part of WA) (Figure 21). The same is true for the endemic WA species (from 3 to 6). In contrast, the number of endemic southern Australian species has remained unchanged (3) and was recorded previously (by Allan (1950) and Cotton (1961) for Acrosterigma cygnorum (Deshayes, 1855), Fulvia tenuicostata (Lamarck, 1819) and Pratulum thetidis (Hedley, 1902)).

Cardiids appear to be more highly concentrated in the IWP than most bivalve families. While Huber (2010: 40) mentions an IWP concentration of about $40 \%$ for known bivalve species, in cardiids, and following a much larger percentage of newly described species available from the IWP since 1975, the IWP portion has risen from $45 \%$ (1975) to $55 \%$ (2016, including the results of the present study) (Figures 22-23). With a significant number of WA cardiids peripherally distributed to the northern offshore reefs (Table 4, Figures 17-20, 24-25) or only rarely recorded from coastal waters, these offshore records are biogeographically of great importance in terms of adding to the species richness of Western Australia. The growing distinction between inshore and offshore macromolluscan faunal signatures was well demonstrated by Wells and Slack-Smith (1986), who added 70 species that were new records for WA (of which three were cardiids, viz. Corculum cardissa, Tridacna (Chametrachea) crocea and Tridacna (Tridacna) gigas), based on surveys to the northern offshore reefs. The number of new records was later increased to 121 molluscan species (Wells 1993; no additional cardiids), based on an additional survey of Ashmore Reef and Cartier Island. Altogether, over

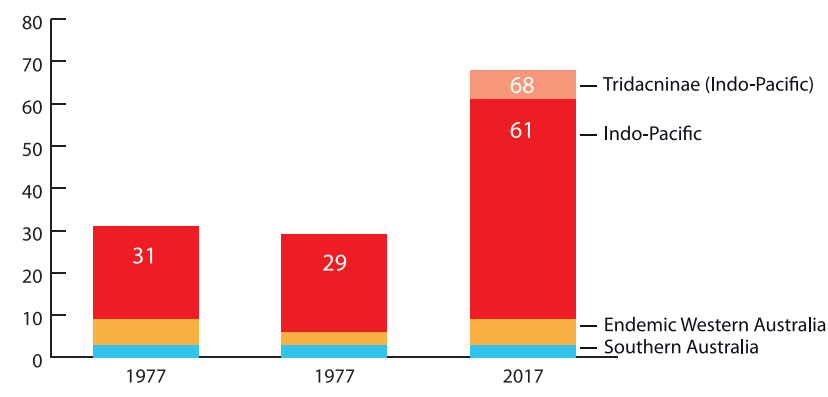

FIGURE 21 Stacked bar graph showing number of valid WA Cardiidae species in 1977 as recognised by Wilson and Stevenson (1977) (left); number of species in 1977 as currently considered valid (middle) and number of species in 2017 (right; Tridacninae indicated in pink), subdivided in three distributional regions.

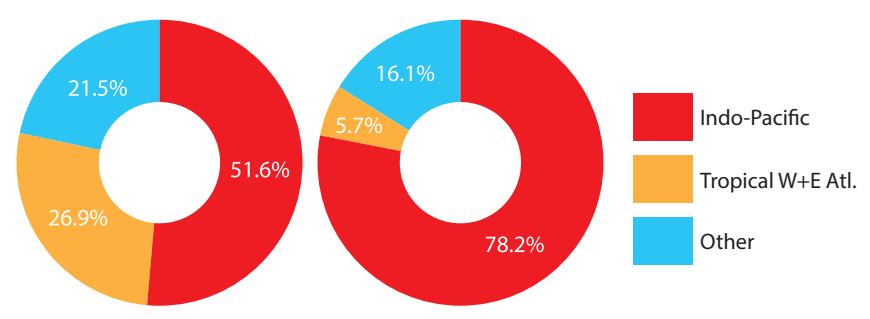

FIGURE 22 Biogeographical source of the new species of marine molluscs described in 2000-2014 (left, $n=6656$; source: Bouchet et al. 2016) in comparison with the new Cardiidae species described in 1976-2016 (right, $n=87$, Lymnocardiinae, Tridacninae and results of present study included; source: WoRMS (2016), supplemented with unpublished data). Indo-Pacific: red; tropical West and East Atlantic: orange; other fauna provinces: blue.

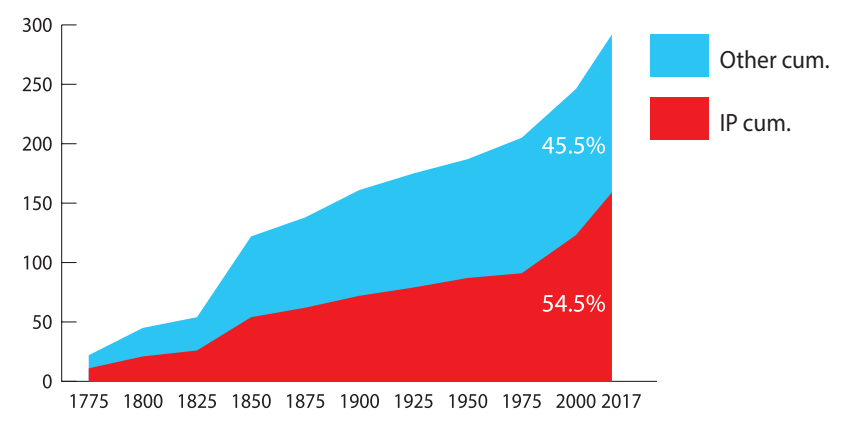

FIGURE 23 Accumulation curve of currently considered valid Cardiidae species described in 17582017 ( $\Sigma=292$, Lymnocardiinae, Tridacninae and results of present study included). IndoPacific (red, $\Sigma=159$ ), other fauna provinces (blue, $\Sigma=133$ ). Source: WoRMS (2016), supplemented with unpublished data. 
$20 \%$ of the molluscs collected on surveys of these atolls proved to be new records for WA (Wells et al. 2000). Surveys to the northernmost reefs carried out by Willan (2005) also yielded a new species record of a large bodied cardiid (Vasticardium mindanense) and quite recently, Bryce and Whisson (2009) added another tridacnine to the WA fauna, viz. Tridacna (Tridacna) derasa, found on Mermaid, Scott and Seringapatam Reefs. There is still more to explore with many offshore areas still unsurveyed. For example, the fauna of Fantome Bank, Karmt Shoal, Loxton Shoal, Sunset Shoal and Troubadour Shoals in the far northeast has still hardly been explored. The recent find of a large Vasticardium sewelli specimen (Figures 16A-D) from this area, known only from QLD (ter Poorten 1997) previously, demonstrates the need for additional sampling programs. More broadly, a focus on these areas will help to resolve the connectivity across the North and highlight how these submerged islands function as stepping stones between the top of Australia and the Coral Triangle.

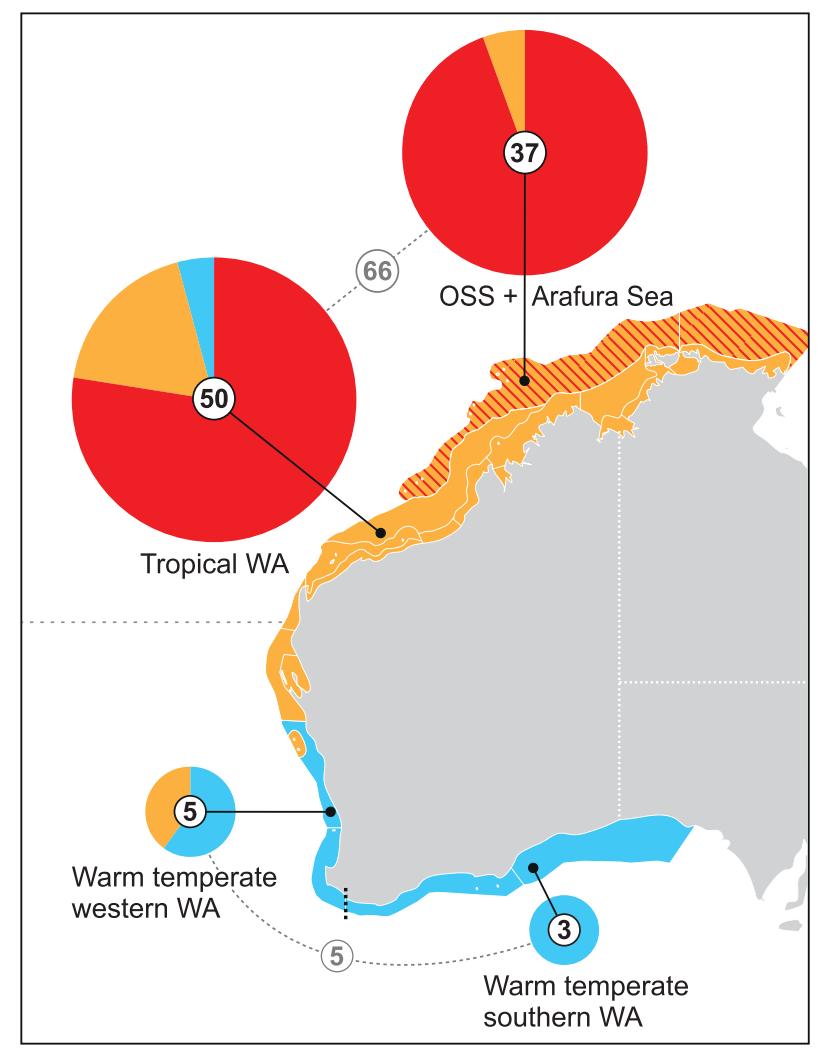

1 Warm temperate WA

2 Tropical northern Australia

3 Indo-West Pacific

FIGURE 24 Pie charts showing zoogeographical composition and diversity of the WA cardiid molluscan fauna and adjacent areas (subdivided in four ecoregions, based on IMCRA bioregions). Number of species for each ecoregion indicated in circles.
Much new research on taxonomy and systematics has occurred on the cardiids since the work by Wilson and Stevenson (1977) forty years ago. One of the most significant developments and one that has greatly altered our understanding of higher level relationships has been the advent of molecular methods. In terms of the cardiids (Kirkendale 2009, Herrera et al. 2015), such approaches have reinforced the inclusion of the Tridacninae in the Cardiidae, but have also led to less certainty in other branches of the cardiid tree. For example, Herrera et al. (2015) demonstrated that Laevicardiinae was polyphyletic, with Frigidocardium, Microcardium and Trifaricardium distributed in a clade basal to all other living cardiids; and that Laevicardiinae is sister to Trachycardiinae, both forming the youngest lineages of the family.

\section{ENDEMISM IN WESTERN AUSTRALIAN CARDIIDS}

Sixteen cardiids occurring on the northern offshore reefs (OSS bioregion) are not known from the continental mainland of WA, resulting in a rather low level of similarity (32\%) between inshore and offshore areas (Figure 26, Appendix). All endemic WA cardiids are restricted to coastal or inshore WA, none of them are recorded from the offshore reefs (Table 4, Figure 24); a pattern that holds for molluses in general (Wells 2002). Not unexpectedly, the northern offshore reef fauna is an extension of a large central IWP distribution rather than an Indian Ocean provenance - also in line with that of molluscs in general, given the present inter-oceanic currents (Hoeksema 2007). The influence of the Indonesian Throughflow (ITF, Figure 1), which supplies the North West Shelf with tropical water from the western Pacific via southeastern Indonesian island corridors (Wilson 2013) has a critical role in distributing planktonic larvae via the seasonal Holloway Current (Wilson 2014) into the Indian Ocean. The phylogeographic observation that much of the eastern Indian Ocean fauna exhibits genetic affinity with the Pacific and not with the Indian Ocean fauna has been recently proposed to be called 'the Leeuwin effect' (Wilson and Kirkendale 2016).

Oceanographic and geographic processes thus drive the higher level of similarity observed in the cardiid fauna of Central/East Indonesia and the northern offshore reefs of WA (41\%), than between inshore and offshore WA (32\% as reported above) (Figure 26, Appendix). Likewise, all non-endemic WA cardiids also occur in Indonesia and/or the Philippines (Table 4, Appendix) and none of them has an exclusively Indian Ocean distribution, again reflecting the general molluscan pattern (Wilson 2013). In fact, the same pattern holds for the cardiids of the AIOT (Christmas Island and Cocos (Keeling) Islands, Table 3), which exhibit a rate of endemism for molluscan species of less than 4\% (Tan and Low 2014). With a level of endemism of approximately $75 \%$ (Huber 2010) or even up to $95 \%$ (Wilson and Allen 1987; Ponder et al. 2002), it is unsurprising that the cardiid level of similarity between northern WA and southern WA is only $3 \%$ 


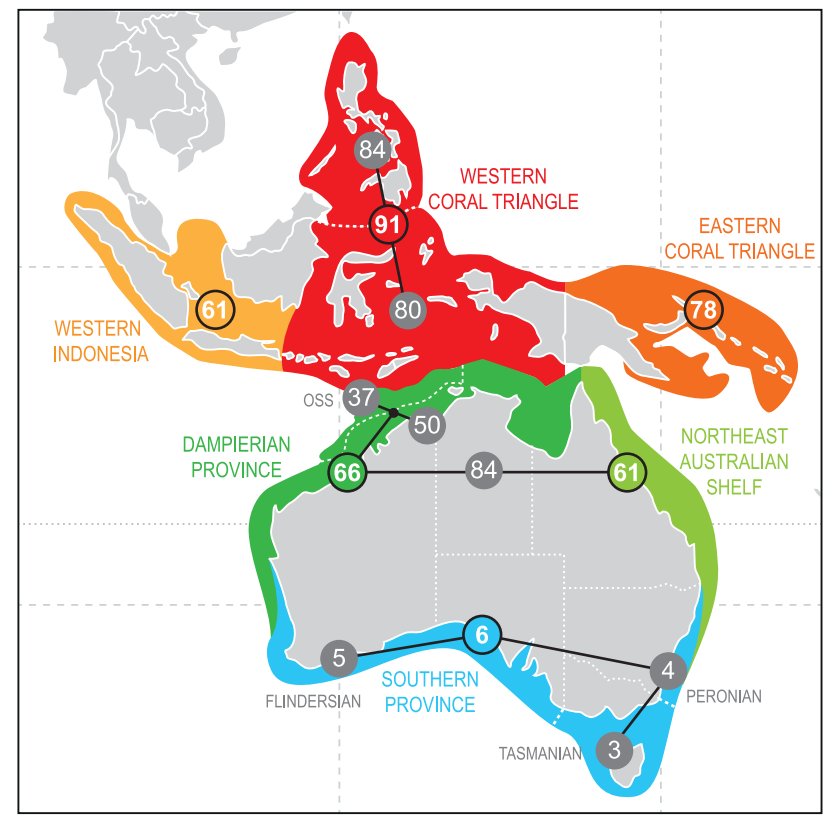

FIGURE 25 Cardiidae diversity in Central IWP and Australia (verified records; Tridacninae included). Number of species in coloured circles; number of subareas and combined areas in white/gray circles.
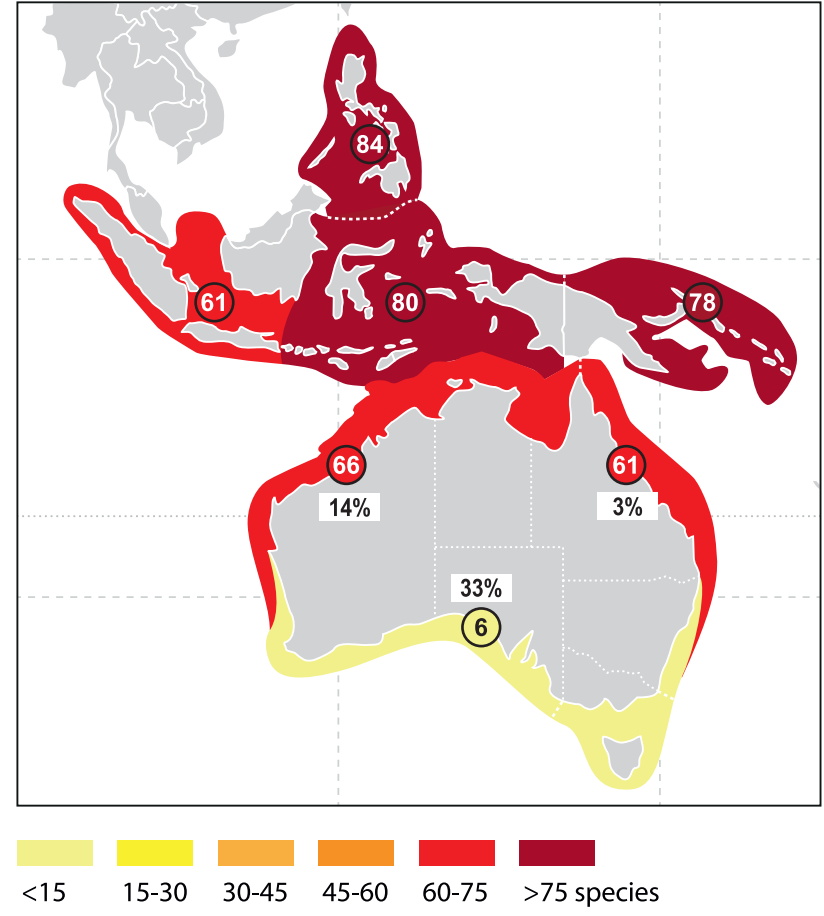

FIGURE 27 Cardiidae diversity in Central IWP and Australia (verified records; Tridacninae included). Number of species in circles. Endemism in Dampierian Province, Solanderian Province and southern Australia in \%.

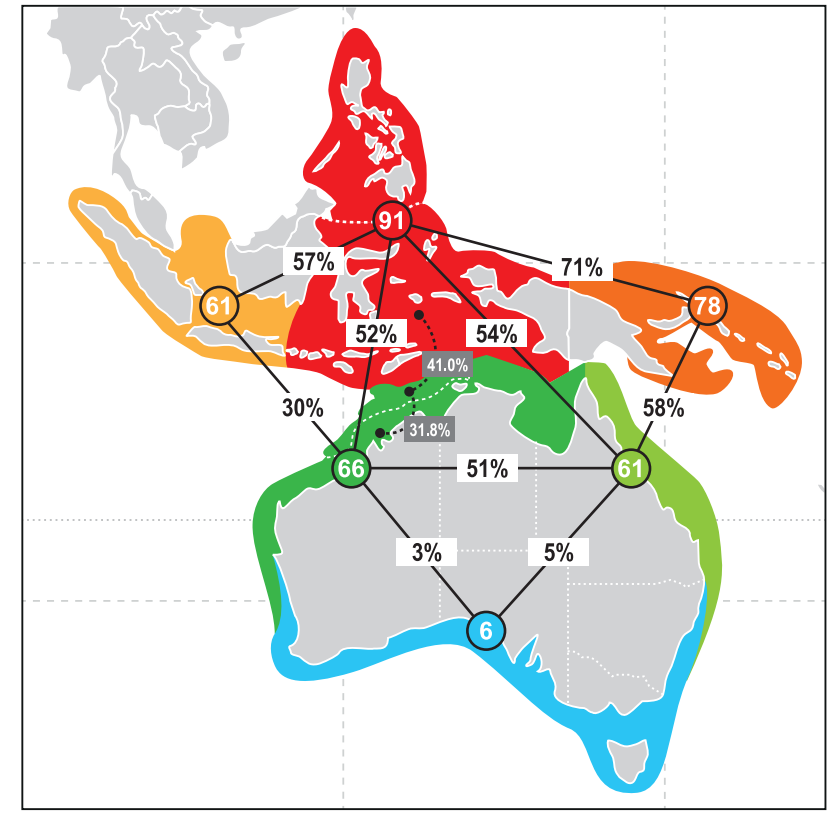

FIGURE 26 Cardiidae levels of similarity in Central IWP and Australia (verified records; Tridacninae included). Number of species in circles.

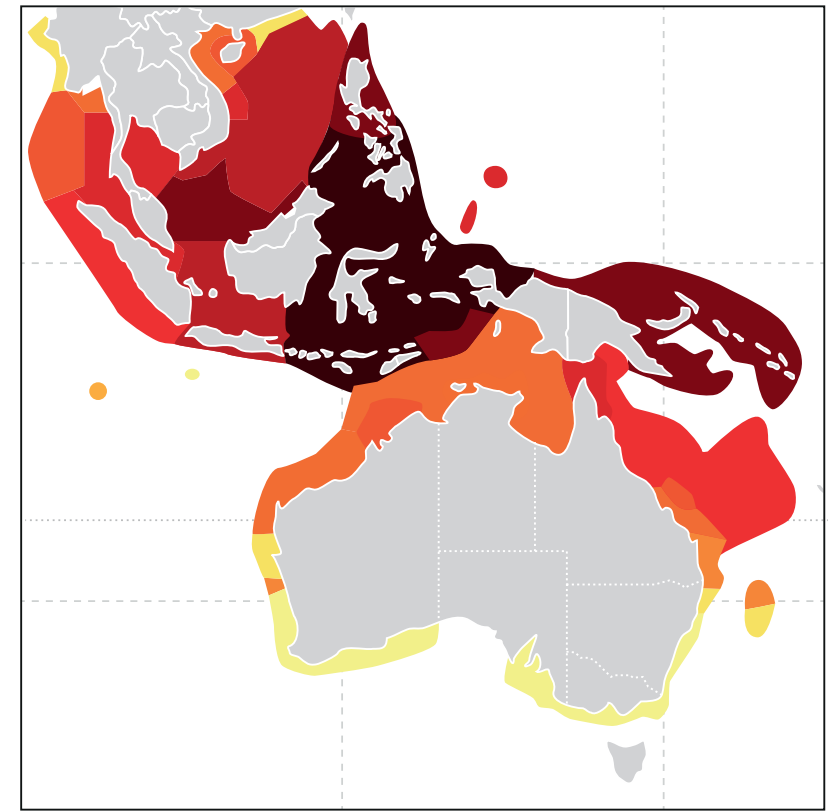

$\begin{array}{lllllllllllll}<50 & 100 & 150 & 200 & 250 & 300 & 350 & 400 & 450 & 500 & 550 & 600 \text { species }\end{array}$

FIGURE 28 Coral diversity in Central IWP ecoregions indicated by all records of occurrences (after Veron et al. 2015: fig. 4). 
(Figure 26, Appendix). Just as in corals (Veron et al. 2015; Figure 28), cardiids of high latitude ecoregions have less similarity with their nearest neighbour than do cardiids in tropical ecoregions (Figure 26). All of these observations corrorborate that tropical WA Pratulum records relate to a different species ( $P$. occidentale $\mathrm{sp}$. nov.), and we confirm here that $P$. thetidis (Hedley, 1902) is an endemic South Australian species, confined to temperate waters in WA and only marginally occurring in deeper waters off southern QLD.

\section{BIODIVERSITY AND BIOGEOGRAPHY ACROSS NORTHERN AUSTRALIAN}

The 25 species comprising the cardiid fauna of the NT (Table 4) (including 4 Tridacninae; none endemic to NT) is much less diverse than that of WA. Large parts of the coasts are dominated by river estuaries and mangrove systems; the development of coral reefs is limited and offshore emergent reefs are lacking. Hence, habitat heterogeneity is more restricted compared to WA. The Joseph Bonaparte Gulf, with its large river systems contributing a lot of silt and freshwater (enhanced by the heavy rainfall in the monsoon season), acts as a barrier, preventing the majority of WA cardiids from crossing the NT border (personal communication R. Willan, 2014). Whereas the northern offshore reefs lie directly in the path of the ITF, this cannot be said for the NT, which is largely lacking these kinds of conduits for dispersal. Connectivity between the Coral Sea and the Arafura Sea has been impeded by a very wide land bridge that fully connected the NT with New Guinea, the Torres Strait remaining closed until 6,000 years BP (Wilson 2013: 315, fig. 2.12). Currently, the narrow and shallow Torres Strait (with the Torres Sill only $12 \mathrm{~m}$ deep) still forms a biogeographic barrier, hampering dispersal of molluscan larvae. Not unexpectedly, the only NT cardiid absent from WA has a marked preference for shallow muddy environments: Fulvia hungerfordi (G.B. Sowerby III, 1901) (Table 4; ter Poorten 2009). Common, widespread shallow water species that prefer clean sand in coral reef environments, like Fragum fragum (Linnaeus, 1758), Microfragum festivum (Deshayes, 1855) and Hippopus hippopus (Linnaeus, 1758), are altogether lacking in the NT. Tridacna species have not been reported from the more turbid and sheltered inshore areas with limited coral growth like the Van Diemen and Beagle Gulfs. Deep water species, like Freneixicardia victor (Angas, 1872), represented in WA by 18 specimens, have not been recorded from the NT (although the scarcity of deeper water biota may be explained by undersampling, not by true absence). Altogether, collecting effort and intensity has been much lower and has been strongly focussed on the Darwin area.

A number of biogeographic provinces in the IWP region have been proposed and some are quite different from one another. While Briggs and Bowen (2012) call for recognition of a vast Indo-Polynesian province, extending from the Arabian Gulf in the Indian ocean to the Tuamotu Archipelago (Polynesia) in the central Pacific Ocean, others recognise increasing levels of structure, such as a number of provinces within the Indo-Polynesian province (Kulbicki et al. 2013) and even Wilson (2013: 9, fig. 1.3) presents a northwestern and northeastern province. However, Wilson (2013) finishes with a strong case for recognition of further biogeographical distinction, specifically a Dampierian Province (p. 392-393) with one of the major aims of his study to consider whether the North West Shelf meets the criteria for designation as a distinctive province within the Northern Australian Subrealm (Wilson 2013: 7). A number of criteria (e.g. geomorphological, climatic, geological) and faunal elements (e.g. also corals, fish, and consideration of levels of endemicity and dissimilarity with other adjacent regions) are considered. Wilson (2013: 391, table 9.1) finds an overall species endemicity of $12 \%$ (in three families that have planktotrophic larvae: Mytilidae, Cardiidae and Strombidae) or 19\% (Cardiidae only) for the area covering the North West Shelf, Arafura Sea, and Gulf of Carpentaria. With the new taxonomy, biodiversity assessments and distributional data presented here for the cardiids, we support a Dampierian Province. Our composite data indicate 14\% endemism (Figure 27, Appendix) and strikingly, all four of the new species described herein represent Dampierian endemics, further attesting to the veracity of this signature. While this level of endemism is not as high as found in the cardiids of temperate southern Australia (Flindersian + Tasmanian + Peronian $=33 \%$ ), it is more than that found for the neighboring Solanderian $3 \%$, Vasticardium serricostatum and the undescribed Trifaricardium sp. the only endemics). The contrast between the neighboring Damperian and Solanderian Provinces is striking in the cardiids and can be explained by the Solanderian Province exhibiting higher levels of similarity with adjacent areas (e.g. 58\% similarity with the Eastern Coral Triangle), such that while the area is rich it is not overly endemic, instead comprised of a number of IWP species (e.g. Table 5, Figures 25, 26). Why the Dampierian is not swamped by IWP species like the Solanderian but instead has developed and retained a stronger endemic signature is the result of many factors (Wilson 2013). Sea level changes and variable current intensity from the north have resulted in unreliable connectivity among populations that may have promoted opportunities for in situ speciation over geological timescales. This coupled with the novel environmental conditions layered across a diversity of microhabitats are certainly important additional drivers in northern WA.

Intensified collection research, combined with increased sampling in the central IWP and the continental shelf off north-western Australia, has greatly enhanced our understanding and broader affinities of the WA cardiid fauna in the past 40 years. A critical review of museum specimens and literature has increased the number of recorded WA Cardiidae species from 29 to 61 
(68 including Tridacninae). In this study, no less than 16 species are reported for the first time from WA, all but one having a wide central IWP range. It is this central IWP component of the WA fauna that was still poorly known in 1977, resulting in a more than doubling of the species number (from 23 to 52). In sharp contrast, the number of Southern Australian species (3) has remained constant (Figures 21, 24). With the vast majority of the additional species being peripherally distributed off the northern coast of WA, and our knowledge of the IWP fauna still far from complete, it is suggested that the IWP component will prove to be of even more importance in the future, resulting in an even steeper latitudinal gradient along the WA coastline (Figures 22-25).

The strong increase of northern WA cardiids is in line with findings that northern Australia forms a distinct diversity 'bulge' (or hotspot) in the southern hemisphere (Crame 2000, Hoeksema 2017). The cardiid diversity of north-western Australia approaches that of Central Indonesia, and except for the four new species, all species added to the WA fauna by this study and Willan et al. (2015), (19 in total) were already known from Indonesia. It appears that regional environmental factors override latitudinal diversity gradient effects, as is argued for northern WA by Wilson (2013). Some cardiids are clearly restricted to the northern WA offshore reefs, which probably have acted as important stepping stones for further colonisation along the WA continental coasts, especially during extraordinary oceanographic events like cyclonic storms. Taking into account mode of development and habitat preferences, there is no reason to believe that the described shifts in the composition of the WA distribution patterns are unique for cardiids. Although certainly improved and indicative, estimates of IWP cardiid diversity are still heavily biased by collecting intensity and are not yet an actual account of the true biodiversity.

Based on the available data for cardiids, the northern Australian diversity approximately equals that of the hyperdiverse Indonesia and Philippines, an outcome already reported for prosobranch gastropods (Wells 1990), but less apparent for corals (Veron et al. 2015; Figures 25-26). At present, the total WA Cardiidae fauna totals 68 species (Table 4), three of which are endemic to South Australia, which leaves 65 species in the tropics. With the addition of the 18 QLD species that do not occur in WA (Table 5), plus Pratulum thetidis, a total of 84 Cardiidae species occur in the tropical northern part of Australia (Figures 23, 25). Philippine diversity is quite well documented (ter Poorten 2009, 2011; unpubl. data) and totals 84 species, while Indonesian diversity was discussed by ter Poorten (2007; unpubl. data) and equals 86 species. The combined Indonesian-Philippine cardiid fauna is 98 species, whereas the combined Indonesian-tropical WA and northern offshore reefs fauna is 99 species (Appendix). These numbers, as well as extrapolations to larger groups should be treated with caution, given the possibility of sampling bias (e.g. overrepresentation of macromolluscs or undersampling of certain regions). However, a sampling bias is also apparent in the WA cardiid fauna, with no specialist methods employed to target cryptic, micromollusc or deep sea habitats until relatively recently (in contrast, specialist methods have been employed in other surveys for decades within the Coral Triangle). Thus the WA cardiid fauna, although underrepresented given a lack of specialist methods and attention, still manages to achieve a biodiversity 'score' on a par with the richest regions in the world. This finding has been recently revisited by Hoeksema (2017) who argued that the boundaries of the central IWP diversity centre are contested and unlikely to be triangular, again calling for a renaming of this area to Indo-Australian Archipelago, to recognise in part the high diversity emerging from Australia (Hoeksema 2007). It also reinforces the notion of Wilson (2013: 269) who argued that viewing the Arafura and Sahul Shelves as part of the East Indies Triangle (approximately coinciding with and recently referred to as the Coral Triangle), or at least an extension of it, is justified, based on the magnitude, affinity, and proximity of the marine biota.

\section{CLOSING THE GAP IN WESTERN AUSTRALIA}

The work by Wilson and Stevenson (1977) was significant as it was one of the first regional treatments of a well known, widespread and conspicuous group in WA. However, taxonomic work on cardiids in WA was not revisited as the WAM collections grew. This lack of expert scrutiny, which can be termed an 'expert bias', has been one issue that has seriously hampered the resolution of distribution patterns and composition of the WA cardiid fauna. While the work presented here redresses this 'expert bias', and identifies material in the WAM collections, it seems likely that the real richness of the WA cardiid fauna is still underestimated. This is largely because much of the WA expedition work has been a 'Rapid Assessment' style that must function across many phyla, with modest sampling efforts (typically approximately 15 to 50 day-persons - Slack-Smith and Bryce 2004: table 1; Bryce and Whisson 2009: table 5) often constrained by extreme environmental conditions (tides, visibility, etc.). This sampling bias in WA cardiids has been made apparent largely due to the recent large scale marine expeditions undertaken to neighbouring countries such as New Caledonia (Bouchet et al. 2002), Vanuatu (Bouchet et al. 2008) and the Philippines (Bouchet 2009) by MNHN. These mollusc and crustacea focused initiatives typically deploy people power of 400 up to 2,000 day-persons and a suite of collecting techniques like scuba-operated vacuum cleaners and newly developed 'brushing baskets'. These methods, coupled with taxonomic expertise necessary to document the fauna in real time, have led to impressive species lists for hyperdiverse areas of the IWP, including cardiids (Vidal 1999, ter Poorten 2009, 2012, 2013, 2015); such work is rapidly improving our knowledge of hidden corners (deep sea, reef matrices) and dark taxa (e.g. cryptic species, small-bodied taxa) (Page 2016). 
Progress is apparent in WA where new light is being shone on these hidden corners and dark taxa. The highly speciose micromolluscan fauna, also containing small and juvenile cardiid species (Wilson 2013), is under study after a long period of inactivity. Approximately 60 stations in the marine area adjacent to the Kimberley (including sites from as far north as Ashmore/Hibernia and as far west as Rowley Shoals) have been sampled for micromolluscs and a subsample of this material has been sorted, photo-documented, registered and identified to morphospecies (Middelfart, unpublished/in preparation, Middelfart et al. 2016). Analysis of these samples is underway and will begin to reveal the presence of small and juvenile cardiids, with a planned expansion of the program to other areas in WA. Like micromolluscs, which are a faunal gap worldwide, the deep sea is a regional gap in WA and poorly known compared to shallow coastal seas. Although the deep water fauna has received little attention in WA (Ponder et al. 2002: Table 3.1), the Southern Surveyor expedition was significant in sampling 123 deep sites from the north to the south of the state, with molluscs deposited in the WAM collections. This expedition improved ranges for several deep water cardiid taxa, provided important material for the description of Pratulum occidentale sp. nov., and the first Australian record of Acrosterigma suduirauti Vidal \& ter Poorten, 2007.

\section{FUTURE GOALS}

Cardiids offer the opportunity to pose the big questions in evolutionary ecology and historical biogeography, given their presence in most ocean basins across a variety of habitats, an excellent fossil record and moderate biodiversity. However, these downstream pursuits fundamentally rely on taxonomy, which beyond nomenclature provide our most accurate understanding of diversity and distribution (Jablonski et al. 2017). In relation to the cardiids, we have certainly made headway in tackling the problem highlighted by Roberts and Wells (1980: 335) that stated the 'marine and estuarine molluscs of the State [WA] are very poorly known'. However, we are still a long way from meeting the challenge recently documented by Willan et al. (2015), with the expectation of 5,000 molluscs in WA, of which we have only documented 1,784 (less than half). Interestingly, a century ago, Hedley (1916: 152) predicted that 'the number [of WA molluscs] will be increased perhaps fourfold when small species and those from deep water are collected.' His species list only contained 14 WA cardiid species. Biodiversity surveys utilizing modern methods aligned with other international surveys to facilitate comparisons need government and industry support. This will enable research teams to continue to reveal the rich biodiversity of local areas, while providing accurate biogeographic assessments to enable broader regional comparisons, all necessary to inform best practise conservation measures (e.g. the placement of Marine Protected Areas or MPAs) at multiple governmental scales (Wilson 2016). While cardiids are relatively popular and well studied, and could be thought of as 'charismatic megafauna' of the molluscan world, many other groups are much more poorly known. The need for collaborations by international taxonomic experts and programs to train the next generation of biodiversity 'hotspotters' to tackle poorly known molluscan groups in Australia, is a massive future frontier.

\section{ACKNOWLEDGEMENTS}

This paper would not have come to light without the kind and dedicated support of the following WAM employees and collaborators (in alphabetical order): Aaron Cosgrove-Wilke, Gladys Hansen, Hugh Morrison, Stacey Osborne, Shirley Slack-Smith and Corey Whisson. Richard Willan (NTM) kindly provided the first author access to the collection and generously shared his knowledge of NT molluscs. He also assisted with discussions concerning identification of Tridacna in the WAM collections. In addition, the authors kindly acknowledge Rob Moolenbeek (RMNH) for help in various ways; Jeroen Goud (RMNH) for information about type material; Philippe Bouchet (MNHN) for fruitful discussions about diversity patterns and for kindly sending the study collection of the late Jacques Vidal as a long term loan at the disposal of the first author; Philippe Maestrati (MNHN) for assistance with SEM photography; John Healy (QM) and Mandy Reid (AMS) for tracing material in their collections. Paul Callomon (ANSP), Amanda Lawless (ANSP), Andreia Salvador (NHMUK), John Slapcinsky (UF) and Kathie Way (NHMUK) are kindly acknowledged for allowing the first author to study cardiid specimens in the collections under their care and for additional information. Sue Hobbs (U.S.A.), J. Hylleberg (Denmark), Eric Kaptein (The Netherlands), Hans van Rij (The Netherlands) kindly enabled the first author to study their collections and/or sent material on loan. David Jablonski (University of Chicago) kindly provided valuable suggestions at manuscript stage. Cardiid research was partly supported by the U.S. National Science Foundation DEB-0919124 / 0918982 / 0919451; travel costs of the first author to Australia were supported by the WAM Molluscs group in the Department of Aquatic Zoology. The third author is very pleased to thank the following persons: Barry Wilson, Shirley Slack-Smith and George Kendrick (WAM), Ian Loch (AMS), Thomas Darragh (Museum of Victoria, Melbourne), Neville Pledge and Ben McHenry (South Australian Museum, Adelaide), John Pether (South African Museum, Cape Town), Richard Kilburn (Natal Museum, Pietermaritzburg), Philippe Bouchet (MNHN), Solene Morris and Kathie Way (NHMUK); their kind support and generous access to both Recent and fossil material from their Institutions (including long term loans), enabled an efficient appraisal of the cardiid species occurring in Australia, southern Africa and adjoining areas. We would like to recognise a small grant from Atlas of Living Australia (ALA) that improved our electronic records of giant clams. WAM 
specimens discussed in this paper have been collected over many years supported by a number of generous grants and often through collaborative projects with external organisations for which we are grateful. The recent, externally funded projects include the Woodside funded Dampier Archipelago research project undertaken by WAM, the Woodside Collections Project (Kimberley), the WAMSI project 3.1.1: Deepwater communities at Ningaloo Reef, in collaboration with the Australian Institute of Marine Science and funded by the Western Australian Marine Science Institute (WAMSI), and the RV Southern Surveyor Voyages in 2005 and 2007 to Western Australia (SS200510 and SS200705) in collaboration with CSIRO and funded by Wealth from Oceans Flagship and the Australian Government Department of Environment Water Heritage and the Arts. The authors would like to acknowledge the constructive comments from Reviewer 2 that greatly improved the structure of the manuscript.

\section{REFERENCES}

Abrard, R. (1946). Fossiles Néogènes et Quarternaires des Nouvelles-Hébrides (Missions E. Aubert de la Rüe, 19341936). Annales de Paléontologie 32: 1-112, pls 1-5.

Adams, H. and Adams, A. (1853-1858). The genera of recent Mollusca; arranged according to their organization. van Voorst, London. Vol. 1: xl + 484 pp.; vol. 2: 661 pp.; vol. 3: 138 pls. [Published in parts: Vol. 1: i-xl (1858), 1-256 (1853), 257-484 (1854). Vol. 2: 1-92 (1854), 93-284 (1855), 285-412 (1856), 413-540 (1857), 541-661 (1858). Vol. 3: pl. 1-32 (1853), 33-96 (1855), 97-112 (1856), 113-128 (1857), $129-138$ (1858)].

Adams, A. and Reeve, L. (1848-1850). Mollusca. In: Adams, A. (ed.). The Zoology of the voyage of H.M.S. Samarang under the command of Captain Sir Edward Belcher C.B., F.R.A.S., F.G.S., during the years 1843-1846. Reeve \& Benham, London. $\mathrm{x}+87$ pp, 24 pls [Cardiidae 31 August 1850].

Agassiz, L. (1846). Nomenclatoris Zoologici Index Universalis, continens nomina systematica classium, ordinum, familiarum et generum animalium omnium tantum viventium quam fossilium, secundum ordinem alphabeticum unicum disposita, adjectis homonymiis plantarum nec non variis adnotationibus et emendationibus. Jent and Gassmann, Solodurum. viii +393 pp.

ALA. Atlas of Living Australia. Available online: http://www. ala.org.au (last accessed on 7 January 2017).

Allan, J. (1950). Australian Shells. With related animals living in the sea, in freshwater and on the land. Georgian House, Melbourne. xix +470 pp., 45 pls.

Audouin, V. (1826). Explication sommaire des planches de Mollusques de l'Égypte et de la Syrie, publiées par JulesCésar Savigny, Membre de l'Institut; offrant un exposé des caractères naturels des genres avec la distinction des espèces. In: 'Description de l'Egypte ou recueil des observations et des recherches qui ont été faites en Egypte pendant l'expédition de l'armée française, publié par les ordres de Sa Majesté l'Empereur Napoléon le Grand.' Histoire naturelle 1(4): 7-56.

Berry, P.F. and Marsh, L.M. (1986). Part I. History of investigation and description of the physical environment. In: Berry, P.F. (ed.) Faunal surveys of the Rowley Shoals, Scott Reef and Seringapatam Reef, North-western Australia. Records of the Western Australian Museum, Supplement 25: 1-25.
Borsa, P., Fauvelot, C., Andréfouët, S., Chai T.-T., Kubo, H. and Liu, L.-L. (2015). On the validity of Noah's giant clam Tridacna noae (Röding, 1798) and its synonymy with Ningaloo giant clam Tridacna ningaloo Penny \& Willan, 2014. Raffles Bulletin of Zoology 63: 484-489.

Borsa, P., Fauvelot, C., Tiavouane, J., Grulois, D., Wabnitz, C., Abdon Naguit, M.R. and Andréfouët, S. (2015). Distribution of Noah's giant clam, Tridacna noae. Marine Biodiversity 45(2): 339-344. doi: 10.1007/s12526-014-0265-9.

Bouchet, P. (2009). From specimens to data, and from seashells to molluscs: The Panglao Marine Biodiversity Project. Vita Malacologica 8: 1-8.

Bouchet, P., Bary, S., Héros, V. and Marani, G. (2016). How many species of molluscs are there in the world's oceans, and who is going to describe them? In: Héros, V., Strong, E. and Bouchet, P. (eds), Tropical Deep-Sea Benthos volume 29. Muséum national d'Histoire naturelle, Paris: 9-24 (Mémoires du Muséum national d'Histoire naturelle 208).

Bouchet, P., Le Guyader, H. and Pascal, O. (2008). Des voyages de Cook à l'expédition Santo 2006: Un renouveau des explorations naturalistes des îles du Pacifique. Journal de la Société des Océanistes 126-127: 167-185.

Bouchet, P., Lozouet, P., Maestrati, P. and Heros, V. (2002). Assessing the magnitude of species richness in tropical marine environments: exceptionally high numbers of molluscs at a New Caledonia site. Biological Journal of the Linnean Society 75(4): 421-436.

Briggs, J.C. (1974). Marine Zoogeography. McGraw-Hill, New York. 475 pp.

Briggs, J.C. (1995). Marine biogeography. Elsevier, Amsterdam. xvii $+452 \mathrm{pp}$.

Briggs, J.C., and Bowen, B.W. (2012). A realignment of marine biogeographic provinces with particular reference to fish distributions. Journal of Biogeography 39(1): 12-30.

Broderip, W.J. and Sowerby, G.B. I (1829). Observations on new or interesting Mollusca contained, for the most part, in the Museum of the Zoological Society. Zoological Journal 4(15): 359-379, pl. 9

Broderip, W.J. and Sowerby, G.B. I (1833). [Characters of new species of shells contained in the collection made by Mr. Cuming on the western Coast of South America, and among the islands of the South Pacific Ocean]. Proceedings of the Zoological Society of London 1: 82-85.

Bruguière, J.G. (1789). Encyclopédie Méthodique, Histoire Naturelle des Vers. Vol. 1(1). Pancoucke, Paris. xviii + $344 \mathrm{pp}$.

Bryce, C. and Whisson, C. (2009). The macromolluscs of Mermaid (Rowley Shoals), Scott and Seringapatam Reefs, Western Australia. Records of the Western Australian Museum, Supplement 77: 177-208.

Bülow, C. (1905). Einige Seltenheiten aus meiner Sammlung. Nachrichtsblatt der Deutschen Malakologischen Gesellschaft 37(2): 78-83, pls 1-2.

Carter, J.G. and Schneider, J.A. (1997). Condensing lenses and shell microstructure in Corculum (Mollusca: Bivalvia). Journal of Paleontology 71(1): 56-61.

Chemnitz, J.H. (1782). Neues systematisches Conchylien Cabinet [...] Sechster Band. Raspe, Nürnberg. 375 pp., 36 pls.

Colgan, D. J. (2015). Marine and estuarine phylogeography of the coasts of south-eastern Australia. Marine and Freshwater Research 67: 1597-1610.

Cotton, B.C. (1961). South Australian Mollusca. Pelecypoda. Hawes, Adelaide. 363 pp. 
Crame, J.A. (2000). The nature and origin of taxonomic diversity gradients in marine bivalves. In: arper, E.M., Taylor, J.D. and Crame, J.A. (eds). The Evolutionary Biology of the Bivalvia. Geological Society, London, Special Publication 177: 347-360.

Dall, W.H. (1890-1903). Contributions to the Tertiary fauna of Florida with especial reference to the Miocene silex-beds of Tampa and the Pliocene beds of the Caloosahatchie River. Transactions of the Wagner Free Institute of Science. 3(1): 1-200 [1890]; 3(2): 201-474 [1892]; 3(3): 475-570, and plates for part 1: pp. 179-190, pls 1-12; plates for part 2: pp. 449-458, pls 13-22 [1895]; 3(4): [i]-viii, 571-948, pls 23-35; [1898]; 3(5): 949-1218, pls 36-47 [1900]; 3(6): [i]-xiv, 1219-1564, pl. 48-60 [1903].

Dall, W.H., Bartsch, P. and Rehder, H.A. (1938). A manual of the Recent and fossil marine pelecypod mollusks of the Hawaiian Islands. Bernice P. Bishop Museum Bulletin 153: i-iv, 1-233, pls 1-58.

Dance, P.S. (1986). A history of shell collecting. $2^{\text {nd }} e d$. Brill \& Backhuys, Leiden. xv +265 pp., 32 pls.

Deshayes, G.P. (1855). Descriptions of new shells from the collection of Hugh Cuming, Esq. Proceedings of the Zoological Society of London 22(279-283): 317-371.

Dunker, G. [W.] (1882). Novitates Conchologicae. Abbildung und Beschreibung neuer Conchylien. Suppl. 7. Index molluscorum Maris Japonici conscriptus et tabulis iconum XVI illustratus. Fischer, Kassel. vii + 301, 16 pls.

Ekman, S. (1953). Zoogeography of the Sea. Sidgwich and Jackson, London. 417 pp.

Fischer-Piette, E. (1977). Révision des Cardiidae (Mollusques, lamellibranches). Mémoires du Muséum national d'Histoire Naturelle, (A, zoologie) 101: 1-212.

Forbes, E. (1856). Map of the distribution of marine life, illustrated chiefly by fishes, mollusks and radiata. In: Johnston, A.K. (ed.), The physical Atlas of natural phenomena (new edition), Johnston and Johnston, London, pl. 31.

Gray, J.E. (1847). A list of the genera of recent Mollusca, their synonyma and types. Proceedings of the Zoological Society of London, 15: 120-129.

Gray, J.E. (1853). A revision of the genera of some of the families of Conchifera or bivalve shells. Annals and Magazine of Natural History. ser. 2, 11: 33-44, 398-402.

Habe, T. (1951-1953). Genera of Japanese shells. Pelecypoda and Scaphopoda. Kairui-bunken-kankokai, Kyoto. [Cardiidae and Tridacnidae in part 2: 144-156 September 1951].

Habe, T. (1961). Four new bivalves from Japan. Venus 21(2): $152-156$.

Habe, T. and Kosuge, S. (1970). Shells of the world in colour. 2. The tropical Pacific. Hoikusha, Osaka. vii + 193 pp., 68 pls.

Harzhauser, M., Piller, W.E. and Steininger, F.F. (2002). Circum-Mediterranean Oligo-Miocene biogeographic evolution- the gastropods' point of view. Palaeogeography, Palaeoclimatology, Palaeoecology 183(1-2): 103-133.

Healy, J. and Lamprell, K. (1992). New species of Veneridae, Cardiidae, Crassatellidae, Tellinidae and Mactridae from Australia (Veneroida, Bivalvia, Mollusca). Journal of the Malacological Society of Australia 13(1): 75-97.

Hedley, C. (1899). The Mollusca of Funafuti. 2. Pelecypoda and Brachiopoda. Memoirs of the Australian Museum 3(8): 489-535.

Hedley, C. (1904). The effect of the Bassian isthmus upon the existing marine upon the existing marine fauna: A study in ancient geography. Proceedings of the Linnean Society of New South Wales 28(4): 876-883.

Hedley, C. (1906). The mollusca of Mast Head Reef, Capricorn Group, Queensland. Proceedings of the Linnean Society of New South Wales 31(3): 453-459, pls 36-38.
Hedley, C. (1909). Mollusca from the Hope Islands, North Queensland. Proceedings of the Linnean Society of New South Wales 34(3): 420-466, pls 36-44.

Hedley, C. (1910). The marine fauna of Queensland. Report of the Australian Association for the advancement of Science 12: 329-371.

Hedley, C. (1916). A preliminary index of the mollusca of Western Australia. Journal and Proceedings of the Royal Society of Western Australia 1: 152-226.

Hedley, C. (1921). A revision of the Australian Tridacna. Records of the Australian Museum 13(4): 163-172, pls 27-34.

Hedley, C. (1926). Zoogeography. In: Jose, A.W. and Carter, H.J. (eds). Australian Encyclopedia., Vol. II, M to Z. Angus \& Robertson, Sydney, p. 743.

Herrera, N.D., ter Poorten, J.J., Bieler, R., Mikkelsen, P.M., Strong, E.E., Jablonski, D. and Steppan, S.J. (2015). Molecular phylogenetics and historical biogeography amid shifting continents in the cockles and giant clams (Bivalvia: Cardiidae). Molecular Phylogenetics and Evolution 93: 94-106. doi:10.1016/jympev.2015.07.013.

Higo, S., Callomon, P. and Goto, Y. (1999). Catalogue and bibliography of the marine shell-bearing Mollusca of Japan. Elle Scientific Publications, Osaka. 749 pp.

Hoeksema, B.W. (2007). Delineation of the Indo-Malayan centre of maximum marine biodiversity: The Coral Triangle. In: W. Renema, W. (ed.) Biogeography, time, and place: Distributions, barriers, and islands. Topics in Geobiology 29: 117-178.

Hoeksema, B.W. (2017). The hidden biodiversity of tropical coral reefs. Biodiversity 18. doi:10.1080/14888386.2017. 1307787.

Huber, M. (2010). Compendium of bivalves. A full color guide to 3,300 of the world's marine bivalves. A status on Bivalvia after 250 years of research. Conchbooks, Hackenheim. 901 pp., 1 CD-Rom.

Huber, M. (2013). Corculum lorenzi $\mathrm{n}$. sp., the true $7^{\text {th }}$ species (Bivalvia: Cardiinae: Fraginae). Conchylia 43(1-4): 17-21.

Huber, M. and ter Poorten, J.J. (2007). Frigidocardium iris spec. nov., a striking species from the Central Indo-Pacific, compared with $F$. exasperatum (Bivalvia, Cardiidae). Visaya 2 (2): 104-111.

Huelsken, T., Keyse, J., Liggins, L., Penny, S., Treml, E.A. and Riginos, C. (2013). A novel widespread cryptic species and phylogeographic patterns within several Giant clam species (Cardiidae: Tridacna) from the Indo-Pacific Ocean. PLoS ONE 8 (11): e80858. doi: 10.1371/journal.pone.0080858.

Hylleberg, J. (2004). Lexical approach to Cardiacea. 1. Literature; 2-3. Records of taxa. Illustrated and annotated records of living and fossil shells, with emphasis on the families Cardiidae and Lymnocardiidae (Mollusca: Bivalvia). Phuket Marine Biological Center Special Publication 29: 1-352; 30: 353-940.

Hylleberg, J. (2017). History and description of Vasticardium mindanense (Reeve, 1844) (Bivalvia: Cardiidae), compared with V. compunctum Kira, 1959, V. ngai Thach, 2016, V. kengaluorum (Voskuil \& Onverwagt, 1993) and $V$. rubicundum (Reeve, 1844). Novapex 18(1-2): 1-16.

ICZN (1999). International Code of Zoological Nomenclature. Fourth Edition. International Trust for Zoological Nomenclature, London. xiii +306 pp

Iredale, T. (1924). Results from Roy Bell's molluscan collections. Proceedings of the Linnean Society of New South Wales 49(3): 179-279, pls 33-36.

Iredale, T. (1927). New molluscs from Vanikoro. Records of the Australian Museum 16(1): 73-78

Iredale, T. (1929). Queensland molluscan notes, no. 1. Memoirs of the Queensland Museum 9: 261-297, pls 30-31. 
Iredale, T. (1936). Australian molluscan notes, no. 2. Records of the Australian Museum 19(5): 267-340, pl. 20-24.

Issel, A. (1869). Malacologia del Mar Rosso. Ricerche zoologiche e paleontologiche. Biblioteca Malacologica, Pisa. xi $+387,5$ pls.

Jablonski, D., S. Huang, K. Roy, J.W. Valentine. (2017). Shaping the Latitudinal Diversity Gradient: New Perspectives from a Synthesis of Paleobiology and Biogeography. The American Naturalist 189 (1): 1-12.

Johnson, M.S., J. Prince, A. Brearley, N.L. Rosser, R. Black. (2016). Is Tridacna maxima (Bivalvia: Tridacnidae) at Ningaloo Reef, Western Australia? Molluscan Research 36 (4): 264-270. doi: 10.1080/13235818.2016.1181141.

Keen, A.M. (1937). Nomenclatural units of the pelecypod family Cardiidae. Bulletin du Musée royal d'Histoire naturelle de Belgique 13 (7): 1-22.

Keen, A.M. (1951). The pelecypod family Cardiidae: A taxonomic summary. Tulane Studies in Geology and Paleontology 16 (1): 1-40.

Keen, A.M., (1969). Superfamily Cardiacea Lamarck, 1809, In: Moore, R.C. (ed.): Treatise on Invertebrate Paleontology, Part N, Volume 2 (of 3), Mollusca 6, Bivalvia. Geological Society of America, Boulder and University of Kansas, Lawrence: pp. N583-N594, figs E84-E89.

Kendrick, G.W. (1990). A Pleistocene molluscan fauna with Anadara trapezia (Deshayes) (Bivalvia: Arcoida) from the Dampier Limestone of Shark Bay, Western Australia. In: Berry, P.F., Bradshaw, S.D. and Wilson, B.R. (eds.), Research in Shark Bay. Report of the France-Australe Bicentenary Expedition Committee. Western Australian Museum, Perth, pp. 33-48.

Keys, J.L. and Healy, J.M. (1999). Sperm ultrastructure of the giant clam Tridacna maxima (Tridacnidae: Bivalvia: Mollusca) from the Great Barrier Reef. Marine Biology 135: 41-46.

Kira, T. (1954). [Coloured illustrations of the shells of Japan]. Hoikusha, Osaka. [viii] $+272+24$ pp, 67 pls. [in Japanese]

Kira, T. (1959). Coloured illustrations of the shells of Japan. Enlarged and revised edition. Hoikusha, Osaka. [vii] + 239 pp, 71 pls. [in Japanese]

Kira, T. (1962). Shells of the western Pacific in color. Vol. 1. Hoikusha, Osaka. vii + 224 pp., 72 pls.

Kirkendale, L. (2009). Their Day in the Sun: molecular phylogenetics and origin of photosymbiosis in the 'other' group of photosymbiotic marine bivalves (Cardiidae: Fraginae). Biological Journal of the Linnean Society 97(2): 448-465.

Kirkendale, L. and Paulay, G. (2017). Part N, Revised, Volume 1, Chapter 9: Photosymbiosis in Bivalvia. Treatise Online 89: 1-31.

Kulbicki. M., Parravicini, V., Bellwood, D.R., Arias-Gonzàlez, E., Chabanet, P., Floeter, S.R., Friedlander, A., McPherson, J., Myers, R.E., Vigliola, L. and Mouillot, D. (2013) Global Biogeography of Reef Fishes: A Hierarchical Quantitative Delineation of Regions. PLOS ONE 8(12): 1-11. e81847. doi: 10.1371/journal.pone.0081847.

Kuroda, T. (1929). Notes and descriptions of some new and noteworthy species from Tateyama Bay in the report of Mr. T. Fujita. In: Fujita, T. Reports on the dredged shells of Tateyama Bay (2). Venus 1(3): 93-97.

Kuroda, T. and Habe, T. (1951). Nomenclatorial notes. In: T. Kuroda (ed.). Illustrated catalogue of Japanese shells 13: 86.

Lamprell, K. and Healy, J. (1998). Bivalves of Australia. Volume 2. Backhuys, Leiden. 1-288.

Lamprell, K. and Whitehead, T. (1992). Bivalves of Australia. Volume 1. Crawford House, Bathurst. xiii + 182 pp.
Linnaeus, C. (1758). Systema naturae, per regna tria naturae, secundus classes, ordinis, genera, species, cum characteribus, differentiis, synonymis, locis. Tomus 1 . Editio Decima, Reformata. Salvius, Stockholm. iii +824 pp.

Lynge, H. (1909). The Danish expedition to Siam 1899-1900. 4. Marine Lamellibranchiata. Mémoires de l'Académie Royale des Sciences et des Lettres de Danemark, Copenhague, 7e série, 5(3): 100-299, pls 1-5.

Maes, V. Orr (1967). The littoral marine molluscs of the Cocos-Keeling Islands (Indian Ocean). Proceedings of the Academy of Natural Science Philadelphia 119(4): 93-217.

Martens, E.C. von (1870). Mollusca. In: Günther, A.C.L.G. (ed.). The Record of zoological literature. 1869. Volume 6. Van Voorst, London: 505-593.

Martens, E. [C.] von (1880). Mollusken. In: K.A. Möbius, F. Richters and E. von Martens (eds). Beiträge zur Meeresfauna der Insel Mauritius und der Seychellen. Enslin, Berlin: 179-352, pl. 22.

Martyn, T. (1784-1787). The universal conchologist, exhibiting the figure of every known shell accurately drawn and painted after nature with a new systematic arrangement by the author. Martyn, London. 4 vols., 161 pls (1, 2: 1-39, pls 1-80, 1784; 3: pls 81-120, 1786; 4: pls 121-160, frontis., 1787).

Maxwell, S.J., Congdon, B.C. and Rymer, T.L. (2016). A new species of Vasticardium (Bivalvia: Cardiidae) from Queensland, Australia. The Festivus 48(4): 248-252.

Mayr, E., Linsley, E.G. and Usinger, R.L. (1953). Methods and principles of systematic zoology. McGraw-Hill, New York, $\mathrm{ix}+328 \mathrm{pp}$.

McNamara, K.J. and Kendrick, C.W. (1994). Cenozoic molluscs and echinoids of Barrow Island, Western Australia. Records of the Western Australian Museum, Supplement 51: 1-50.

Meechan, C. (1987). Handlist of the molluscan collections in the department of zoology, National Museum of Wales. Series 1. The Melvill-Tomlin collection. Part 41. Cardiacea. 1-13; i-vii + [1-9], 1-2. National Museum of Wales, Cardiff. Digitally searchable at http://www.museumwales.ac.uk/bio/ database/bivalves/

Meek, F.B. (1876). A report on the invertebrate Cretaceous and Tertiary fossils of the Upper Missouri Country. Reports of the U.S. Geology and Geography Surveys of the Territories 9: $629 \mathrm{pp} ., 45 \mathrm{pls}$

Megerle von Mühlfeld, J.K. (1811). Entwurf eines neuen System's der Schalthiergehäuse. Erste Abtheilung. Die Muscheln. Magazin der Gesellschaft Naturforschender Freunde zu Berlin 5(1): 38-72.

Melvill, J.C. (1909). Report on the marine Mollusca obtained by Mr. J. Stanley Gardiner, F.R.S., among the islands of the Indian Ocean in 1905. Transactions of the Linnean Society of London, ser. 2 (Zoology), 13: 65-138, pl. 5.

Melvill, J.C. and Standen, R. (1899). Report on the marine mollusca obtained during the first expedition of Prof. A.C. Haddon to the Torres Straits, in 1888-89. Journal of the Linnean Society of Zoology 27(11): 150-206, pls 10-11.

Melvill, J.C. and Standen, R. (1907). The Mollusca of the Persian Gulf, Gulf of Oman, and Arabian Sea, as evidenced mainly through the collections of Mr. F.W. Townsend, 1893-1906; with descriptions of new species. 2 Pelecypoda. Proceedings of the Zoological Society of London 74(4): 783-848, pls 53-56.

Middelfart, P.U., Kirkendale, L.A., Wilson, N.G. (2016). Australian Tropical Marine Micromolluscs: An Overwhelming Bias. Diversity 8(3). doi: 10.3390/d8030017.

Monsecour, K. (2016). A new species of Giant Clam (Bivalvia: Cardiidae) from the Western Indian Ocean. Conchylia 46(1-4): 69-77. 
Morrison, H. and Wells, F.E. (2005). A new species of Melo (Gastropoda: Volutidae) from northwestern Australia. Records of the Western Australian Museum 22: 343-351.

Morton, B. (2000). The biology and functional morphology of Fragum erugatum (Bivalvia: Cardiidae) from Shark Bay, Western Australia: The significance of its relationship with entrained zooxanthellae. Journal of Zoology, London. 251: $39-52$.

Noda, H. (1988). Molluscan fossils from the Ryukyu Islands, Southwest Japan. Part 2. Gastropoda and Pelecypoda from the Shinzato Formation in the middle part of Okinawa-jima. Science reports of the Institute of Geoscience, University of Tsukuba, Section B, 9: 29-85, pls 5-19.

Nomura, S. (1933). Catalogue of the Tertiary and Quaternary Mollusca from the island of Taiwan (Formosa) in the Institute of Geology and Palaeontology, Tôhoku Imperial University, Sendai, Japan. Part 1. Pelecypoda. Scientific Reports of the Tôhoku Imperial University, second series $\mathbf{1 6}$ (1): 1-108, pls 1-4.

Otuka, Y. (1937). Notes on some shells from southern Taiwan (3). Venus 7(3): 128-143.

OZCAM. Online Zoological Collections of Australian Museums, http://ozcam.ala.org.au (date last accessed: 7 January 2017)

Page, R.D.M. (2016). DNA barcoding and taxonomy: dark taxa and dark texts. Phil. Trans. R. Soc. B 371: 20150334. doi: 10.1098/rstb.2015.0334.

Penny, S. and Willan, R.C. (2014). Description of a new species of giant clam (Bivalvia: Tridacnidae) from Ningaloo Reef, Western Australia. Molluscan Research 34(3): 201-211.

Persselin, S.L. (1998). The evolution of shell windows within the Fraginae (Bivalvia: Cardiidae) and the origin of algal symbiosis in cardiids. M.S. Thesis in Biology, University of Guam. 49 pp.

Pilsbry, H.A. (1904). New Japanese marine mollusca: Pelecypoda. Proceedings of the Academy of Natural Sciences of Philadelphia 56: 550-561, pls 39-41.

Ponder, W., Hutchings, P. and Chapman, R. (2002). Overview of the conservation of Australian marine invertebrates. A report for environment Australia. Asutralian Museum, Sydney, $588 \mathrm{pp}$.

Poorten, J.J. ter, (1997). Acrosterigma sewelli (Prashad, 1932), a valid species from the central Indo-Pacific, compared with Acrosterigma flava (Linnaeus, 1758) (Bivalvia, Cardiidae). Basteria 61(1-3): 33-39.

Poorten, J.J. ter, (2005). Outline of a systematic index - Recent Cardiidae (Lamarck, 1809). Visaya Net 14: 1-13. Online available http://www.conchology.be/?t=41\&p=3.

Poorten, J.J. ter, (2007). Results of the Rumphius Biohistorical Expedition to Ambon (1990). Part 13. Mollusca, Bivalvia, Cardiidae. Zoologische Mededelingen Leiden 81: 259-301.

Poorten, J.J. ter, (2009). The Cardiidae of the Panglao Marine Biodiversity Project 2004 and the Panglao 2005 Deep-Sea Cruise with descriptions of four new species (Bivalvia). Vita Malacologica 8: 9-96.

Poorten, J.J. ter, (2011). Cardiidae. In: Poppe, G.T. (ed.). Philippine marine mollusks. 4. Bivalvia part 2, Scaphopoda, Polyplacophora, Cephalopoda \& addenda. ConchBooks, Hackenheim. 676 pp.

Poorten, J.J. ter, (2012). Fulvia (Fulvia) nienkeae spec. nov., a new Fulvia from the Central Indo-West Pacific (Bivalvia, Cardiidae). Basteria 76(4-6): 117-125.

Poorten, J.J. ter, (2013). Revision of the Recent species of the genus Nemocardium Meek, 1876 (Bivalvia, Cardiidae), with the descriptions of three new species. Basteria 77(4-6): 45-73.

Poorten, J.J. ter, (2015). Fragum vanuatuense spec. nov., a small new Fragum from the Central Indo-West Pacific (Bivalvia, Cardiidae). Basteria 79(4-6): 114-120.
Poorten, J.J. ter, and Huber, M. (2007). Trifaricardium morrisoni sp. nov., a new deep water cardiid from off Western Australia, with notes on T. nomurai Kuroda \& Habe, 1951 (Bivalvia, Cardiidae). Basteria 71(1-3): 71-74.

Poorten, J.J. ter and Hylleberg, J. (2017). Fulvia kaarei spec. nov., a new Fulvia from Vietnam (Bivalvia, Cardiidae). Basteria 81(4-6): 111-118.

Poorten, J.J. ter, and van Gemert, L. (2016). The genus Frigidocardium Habe, 1951 in the Red Sea (Bivalvia, Cardiidae). Basteria 80(1-3): 64-76.

Poutiers, J.M. (1981). Mollusques: Bivalves. In: Résultats des campagnes Musorstom. I — Philippines (18-28 mars 1976). Mémoires ORSTOM 91: 325-356, pls 1-4.

Poutiers, J.M. (1992). The Australasian Protocardiinae revisited (Bivalvia: Cardiidae). American Malacological Bulletin 9 (2): 139-144.

Poutiers, J.M. (2006). Two new species of protocardiine cockles (Mollusca, Bivalvia, Cardiidae) from the tropical Southwest-Pacific. Zoosystema 28(3): 635-654.

Prashad, B. (1932). The Lamellibranchia of the Siboga Expedition. Systematic part. II. Pelecypoda (exclusive of the Pectinidae). - Siboga-Expeditie: uitkomsten op zoölogisch, botanisch, oceanographisch en geologisch gebied verzameld in Nederlandsch Oost-Indië 1899-1900 aan boord H.M. Siboga onder commando van Luitenant ter Zee le kl. G.F. Tydeman 53c(118): 1-353, pls 1-9, chart.

Reeve, L.A. (1844). Conchologia Iconica: or, illustrations of the shells of molluscous animals. 2. Monograph of the genus Cardium. Reeve, London. sp. 1-64 (sp. 47 excluded), pls $1-12$.

Reeve, L.A. (1845). Conchologia Iconica: or, illustrations of the shells of molluscous animals. 2. Monograph of the genus Cardium. Reeve, London. sp. 47, 65-133, pls 13-22.

Röding, P. F. (1798). Museum Boltenianum sive catalogus cimeliorum e tribus regnis naturæ quæ olim collegerat Joa. Fried Bolten, M. D. p. d. per XL. annos proto physicus Hamburgensis. Pars secunda continens conchylia sive testacea univalvia, bivalvia \& multivalvia. pp. [1-3], [1-8], 1-199. Hamburgi. (Trapp).

Richards, Z., Kirkendale, L., Moore, G., Hosie, A., Huisman, J., Bryce, M., Marsh, L., Bryce, C., Hara, A., Wilson, N., Morrison, S., Gomez, O., Ritchie, J., Whisson, C., Allen, M., Betterridge, L., Wood, C.., Morrison, H., Salotti, M., Hansen, G., Slack-Smith, S. and Fromont, J. (2016). Marine biodiversity in temperate Western Australia: Multi-taxon surveys of Minden and Roe Reefs. Diversity 8(7): 1-25. doi: $10.3390 / \mathrm{d} 8020007$.

Roberts, D. and Wells, F. (1980). The marine and estuarine molluscs of the Albany area of Western Australia. Records of the Western Australian Museum 8(3): 335-357.

Rosewater, J. (1965). The family Tridacnidae in the IndoPacific. Indo-Pacific Mollusca 1(6): 347-398.

Schneider, J.A. (1995). Phylogeny of the Cardiidae (Mollusca, Bivalvia): Protocardiinae, Laevicardiinae, Lahilliinae, Tulongocardiinae subfam. n. and Pleuriocardiinae subfam. n. Zoologica Scripta 24(4): 321-346.

Schneider, J.A. (1998). Phylogeny of the Cardiidae (Bivalvia): Phylogenetic relationships and morphological evolution within the subfamilies Clinocardiinae, Lymnocardiinae, Fraginae and Tridacninae. Malacologia 40(1-2): 321-373.

Schneider, J.A. (2002). Phylogeny of cardiid bivalves (cockles and giant clams): revision of the Cardiinae and the importance of fossils in explaining disjunct biogeographical distributions. Zoological Journal of the Linnean Society 136(3): 321-369.

Schneider, J.A. and J.G. Carter (2001). Evolution and phylogenetic significance of cardioidean shell microstructure (Mollusca, Bivalvia). Journal of Paleontology 75(3): 607-643. 
Schneider, J.A. and Ó Foighil, D. (1999). Phylogeny of Giant Clams (Cardiidae: Tridacninae) based on partial mitochondrial 16s rDNA gene sequences. Molecular Phylogenetics and Evolution 13(1): 59-66.

Schröter, J.S. (1788). Vollständiges Alphabetisches NamenRegister über alle Zehn Bände des, von dem seel. Herrn D. Martini in Berlin angefangenen, und vom Herrn Pastor Chemnitz in Kopenhagen fortgesezten und follendeten systematischen Conchylien-Cabinets. Raspe,. Nürnberg. $124 \mathrm{pp}$.

Schweigger, A.F. (1820). Handbuch der Naturgeschichte der skelettlosen ungegliederten Thiere. Dyk, Leipsig. 798 pp.

Shikama, T. (1964). Selected shells of the world illustrated in colours (II). Hokuryu-Kan, Tokyo. 212 pp, 70 pls.

Shirley, J. (1912). Additions to the marine mollusca of Queensland. Proceedings of the Royal Society of Queensland 23 (for 1911): 93-102.

Slack-Smith, S.M. and Bryce, C.W. (2004). A survey of the benthic molluscs of the Dampier Archipelago, Western Australia. In: Jones, D.S. (ed.), Report on the results of the Western Australian Museum/Woodside Energy Ltd. partnership to explore the marine biodiversty of the Dampier Archipelago, Western Australia, 1998-2002. Records of the Western Australian Museum Supplement 66: 221-245.

Smith, E.A. (1885). The voyage of H.M.S. Challenger. Zoology. Report on the Lamellibranchiata collected by H.M.S. Challenger during the years 1873-76. (Zoology) 13(35): 1-341, pls 1-25.

Smith, E.A. (1911). A list of marine shells occuring at Christmas Island, Indian Ocean, with descriptions of new species. Proceedings of the Malacological Society of London 9: 315-318.

Sowerby, G.B. II. (1834). The Conchological Illustrations, or Coloured figures of all the hitherto unfigured recent shells. 48th-51th parts. Sowerby, London, 21 figs (11-31).

Sowerby, G.B. II. (1839). The Conchological Illustrations, or Coloured figures of all the hitherto unfigured recent shells. 149th-150th parts. Sowerby, London, 8 figs (32-39).

Sowerby, G.B. II. (1840a). The Conchological Illustrations, or Coloured figures of all the hitherto unfigured recent shells. 177th-184th parts. London, 32 figs (40-71).

Sowerby, G.B. II. [1840b]. Cardium. A catalogue of recent species. [1]-7; Corrected list of figures. 8 .

Sowerby, G.B. II. (1841) [dated 1840]. [An extensive series of new species of the genus Cardium was exhibited by Mr Cuming .... Proceedings of the Zoological Society of London 8(92): 105-111 (May 1841); Annals and Magazine of Natural History, (1) 7 (46): 506-511 (1 August 1841).

Sowerby, G.B. III (1874). Descriptions of twelve new species of shells. Proceedings of the Zoological Society of London (1873): 718-722, pl. 59.

Sowerby, G.B. III (1901). Descriptions of five new species of shells. Journal of Malacology 8(3): 101-103, pl. 9.

Sowerby, G.B. III (1914). Descriptions of new mollusca from New Caledonia, Japan, Philippines, China and West Africa. Annals and Magazine of Natural History, ser. 8, 14(84): 475-480, pl. 19 .

Spalding M.D., Fox, H.E., Allen, G.R., Davidson, N., Ferdaña, Z.A., Finlayson, M., Halpern, B.S., Jorge, M.A., Lombana, A., Lourie, S.A., Martin, K.D., McManus, E., Molnar, J., Recchia, C.A. and Roberston, J. (2007). Marine ecoregions of the world: a bioregionalization of coastal and shelf areas. BioScience 57(7): 573-583.

Spengler, K. (1799). Over den toskallede slaegt hiertemuslingen, Cardium Linnéi. Skrivter af Naturhistorie Selskabet 5(1): $1-60$.
Stewart, R.B. (1930). Gabb's California Cretaceous and Tertiary type Lamellibranchs. Special Publication No. 3 Philadelphia : Academy of Natural Sciences of Philadelphia 314 pp., 17 pls.

Stoliczka, F. (1870-1871) [Cardiidae taxa, p. 204-222, issued September 1st, 1870]. Cretaceous fauna of southern India, 3. The Pelecypoda, with a review of all known genera of this class, fossil and Recent. Memoirs of the Geological Survey of India, Palaeontologia Indica, series 6: i-xxii, 1-538, pls $1-50$.

Su Y., Hung, J.-H., Kubo, H. and Liu, L.-L. (2014). Tridacna noae (Röding, 1798) - a valid giant clam species separated from T. maxima (Röding, 1798) by morphological and genetic data. Raffles Bulletin of Zoology 62: 124-135.

Swainson, W. (1840). A treatise on malacology, or the natural classification of shells and shell-fish. In: Lardner, D. (ed.), The Cabinet Cyclopedia, 6. Natural History. Longman, Rees, Orme, Brown, Green and Longmans, Row and Taylor, London. viii +419 pp.

Tan, S.K. and Low, M.E.Y. (2014). Checklist of the Mollusca of Cocos (Keeling) / Christmas Island ecoregion. Raffles Bulletin of Zoology, Supplement 30: 313-375.

Taylor, J.D. and Glover, E.A. (2004). Diversity and distribution of subtidal benthic molluscs from the Dampier Archipelago, Western Australia; results of the 1999 dredge survey (DA2/99). In: Jones, D.S. (ed.), Report on the results of the Western Australian Museum/Woodside Energy Ltd. partnership to explore the marine biodiversty of the Dampier Archipelago, Western Australia, 1998-2002. Records of the Western Australian Museum Supplement 66: 247-291.

Thackway, R. and Cresswell, I.D. (1998). Interim Marine and Coastal Regionalisaion for Australia: An ecosystem-based classification for marine and coastal environments. Version 3.3. Environment Australia, Commonwealth Department of Environment, Canberra. vii +102 pp.

Thiele, J. (1934). Handbuch der Systematischen Weichtierkunde. Zweiter Band, Teil 3 (Scaphopoda; Bivaliva; Cephalopoda). Fischer, Jena: pp. 779-1022.

Tomlin J.R. le B. (1931). On South African marine mollusca, with description of new genera and species. Annals of the Natal Museum 6(3): 415-450, pl. 33

Veron, J.E.N., Devantier, L.M., Turak, E., Green, A.L., Kininmonth, S., Stafford-Smith, M. and Peterson, N. (2009). Delineating the Coral Triangle. Galaxea, Journal of Coral Reef Studies 11: 91-100.

Veron, J.[E.N.], Stafford-Smith, M., Devantier, L. and Turak, E. (2015). Overview of distribution patterns of zooxanthellate Scleractinia. Frontiers in Marine Science 1: 1-19.

Viader, R. (1951). New or unrecorded shells from Mauritius and its dependencies. Mauritius Institute Bulletin 3(2): 127-155, pls $1-5$.

Vidal, J. (1993). Variability of Acrosterigma elongatum, a polytypic species (Mollusca, Cardiidae). Journal of the Malacological Society of Australia 14: 41-58.

Vidal, J. (1994). A review of the genus Fulvia Gray, 1853 (Mollusca, Cardiidae). Apex 9(4): 93-118.

Vidal, J. (1996). A large Trachycardiinae from the Indo-West Pacific: Vasticardium papuanum, new species. (Mollusca, Cardiidae). Apex 11(2): 77-81.

Vidal, J. (1997). Large Trachycardiinae from the Indo-West Pacific: The group of Vasticardium orbita (Broderip \& Sowerby, 1833) (Mollusca, Cardiidae). Molluscan Research 18(1): 11-32.

Vidal, J. (1999). Taxonomic review of the elongated cockles: genera Trachycardium, Vasticardium and Acrosterigma (Mollusca, Cardiidae). Zoosystema 21(2): 259-335. 
Vidal, J. (2000). Genus Vepricardium Iredale 1929 (Bivalvia, Cardiidae) with description of a new species from Thailand, Vepricardium albohamatum Hylleberg \& Vidal. Phuket Marine Biological Center Special Publication 21(2): 447-464.

Vidal, J. (2001). Siphons and associated tentacles including eyes of Cardiidae (Mollusca: Bivalvia). Phuket Marine Biological Center Special Publication 25(2): 405-410.

Vidal, J. (2003). Two new species in the species-group of Vasticardium assimile (Bivalvia: Cardiidae). Novapex 4(2-3): 57-59.

Vidal, J. and Kirkendale, L. (2007). Ten new species of Cardiidae (Mollusca: Bivalvia) from New Caledonia and the tropical western Pacific. Zoosystema 29(1): 83-107.

Vidal, J. and ter Poorten, J.J. (2007). Acrosterigma suduirauti, a new species of the Acrosterigma uniornatum species group (Bivalvia: Cardiidae) from the Philippines. Novapex 8(2): 71-74.

Voskuil, R.P.A. and Onverwagt, W.J.H. (1988). The genus Vepricardium Iredale, 1929 with description of a new species. Gloria Maris 27(5-6): 86-91.

Voskuil, R.P.A. and Onverwagt, W.J.H. (1991). The taxonomy of the genus Trachycardium (Part 1) with descriptions of three new species (Mollusca: Bivalvia). Vita Marina 41(2): 56-72.

Waters, J. M., Wernberg, T., Connell, S. D., Thomsen, M. S., Zuccarello, G. C., Kraft, G. T., Sanderson, J. C., West, J. A. and Gurgel, C. F. D. (2010), Australia's marine biogeography revisited: Back to the future? Austral Ecology 35: 988-992. doi: 10.1111/j.1442-9993.2010.02114.x

Weber-van Bosse, A. (1904). Een jaar aan boord H.M. Siboga. Brill, Leiden. 337 pp.

Wells, F.E. (1990). Comparative zoogeography of marine molluscs from northern Australia, New Guinea and Indonesia. Veliger 33(2): 140-144.

Wells, F.E. (1993). Part IV. Molluscs of Ashmore Reef and Cartier Island. In: Berry, P.F. (ed.) Marine faunal surveys of Ashmore Reef and Cartier Island, North-western Australia. Records of the Western Australian Museum, Supplement 44: 25-45.

Wells, F.E. (1994). Marine molluscs of the Cocos (Keeling) Islands. Atoll Research Bulletin 410: 1-22.

Wells, F.E. (2002). Centres of species richness and endemism of shallow-water marine molluscs in the tropical Indo-West Pacific. In: Moosa, M.K., S. Soemodihardjo, A. Soegiarto, K. Romimohtarto, A. Nontji, Soekarno and Suharsono (ed.). Proceedings of the Ninth International Coral Reef Symposium, Bali. 23-27 October 2000. 2: 941-946.

Wells, F.E. and Bryce, C.W. (1985). Seashells of Western Australia. Western Australian Museum, Perth. 207 pp., 74 pls.

Wells, F.E., Bryce, C.W., Clark J.E. and Hansen, G.M. (1990). Christmas Shells. The Marine Molluscs of Christmas Island (Indian Ocean). Natural History Association Christmas Island, Christmas Island. iii +99 pp.

Wells, F.E. and Berry, P.F. (2000). Introduction. In: Berry, P.F. and F.E. Wells (eds.). Survey of the marine fauna of the Montebello Islands, Western Australia and Christmas Island, Indian Ocean. Records of the Western Australian Museum, Supplement 59: 3-4.

Wells, F.E. and Slack-Smith, S.M. (1986). Part IV. Molluscs. In: Berry, P.F. (ed.). Faunal surveys of the Rowley Shoals, Scott
Reef and Seringapatam Reef, North-western Australia. Records of the Western Australian Museum, Supplement 25: 41-58.

Wells, F.E., Slack-Smith, S.M. and Bryce, C.W. (2000). Molluscs of the Montebello Islands. In: Berry, P.F. and F.E. Wells (eds.). Survey of the marine fauna of the Montebello Islands, Western Australia and Christmas Island, Indian Ocean. Records of the Western Australian Museum, Supplement 59: $29-46$.

Whitley, G. P. (1932). Marine zoogeographical regions of Australasia. The Australian Naturalist 8(8): 166-167.

Willan, R.C. (2005). The molluscan fauna from the emergent reefs of the northernmost Sahul Shelf, Timor Sea Ashmore, Cartier and Hibernia Reefs; biodiversity and zoogeography. The Beagle, Records of the Museums and Art Galleries of the Northern Territory 2005. Supplement 1: 51-81.

Willan, R.C., Bryce, C. and Slack-Smith, S.M. (2015). Kimberley marine biota. Historical data: molluscs. Records of the Western Australian Museum, Supplement 84: 287-343.

Wilson, B.R. (1998). Superfamily Cardioidea. In: Beesley, P.L., Ross, G.J.B. and Wells, A. (eds), Mollusca: The Southern Synthesis. Fauna of Australia. Vol. 5. Part A. CSIRO, Melbourne, pp. 328-332

Wilson, B.[R.]. (2013). The biogeography of the Australian North West Shelf: environmental change and life's response. Elsevier, Burlington. $\mathrm{x}+413$ pp.

Wilson, B.[R.]. (2014). Kimberley marine biota. History and environment. Records of the Western Australian Museum, Supplement 84: 1-18.

Wilson, B.R. (2016). The Western Australian marine conservation reserves system, Chapter 7. In: Fitzsimmons, J. and Wescott, G. (eds) Big, Bold and Blue. CSIRO, Victoria, pp. 117-137.

Wilson, B.R. and Allen, G.R. (1987). Major components and distribution of marine fauna. In: Dyne, G.R. and Walton, D.W. (eds). Fauna of Australia, Vol. 1A, General articles. Australian Government Publishing Service, Canberra, pp. 43-68.

Wilson, B.R. and Gillett, K. (1971). Australian Shells. Reed and Reed, Sydney, 168 pp.

Wilson, B.R. and Stevenson, S.E. (1977). Cardiidae (Mollusca, Bivalvia) of Western Australia. Western Australian Museum Special Publication 9: 1-114.

Wilson, N.G. and Kirkendale, L. (2016). Putting the 'Indo' back into the Indo-Pacific: resolving marine phylogeographic gaps. Invertebrate Systematics 30: 86-94.

WoRMS (2016). Cardiidae Lamarck, 1809. In: MolluscaBase (2016). Accessed through: World Register of Marine Species at http://www.marinespecies.org/aphia. php? $\mathrm{p}=$ taxdetails\&id=229 on 2016-02-27.

Yokoyama, M. (1927). Mollusca from the upper Musashino of Tokyo and its suburbs. Journal of the Faculty of Science, Imperial University of Tokyo, Section 2, 1(10): 391-437, pls $46-50$.

Zuschin, M. and Oliver, P.G. (2003). Bivalves and bivalve habits in the northern Red Sea. The Northern Bay of Safaga (Red Sea, Egypt): An actuopalaeontological approach. 6 Bivalvia. Naturhistorisches Museum, Wien. 304 pp.

MANUSCRIPT RECEIVED 8 SEPTEMBER 2016; ACCEPTED 10 JULY 2017. 


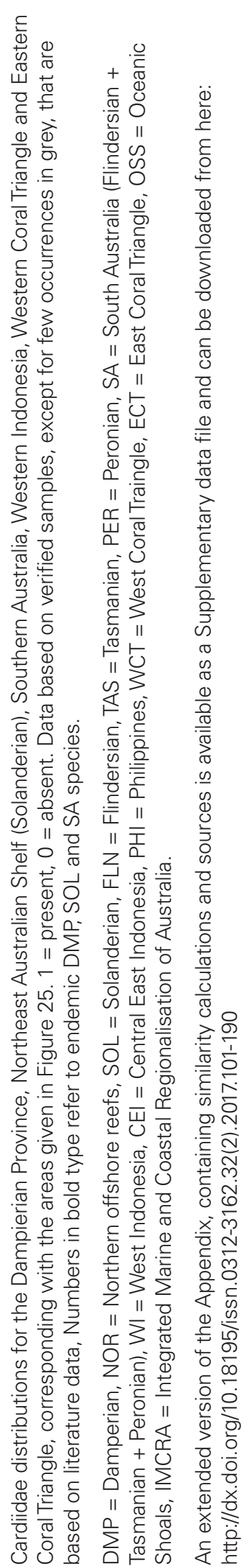

竞

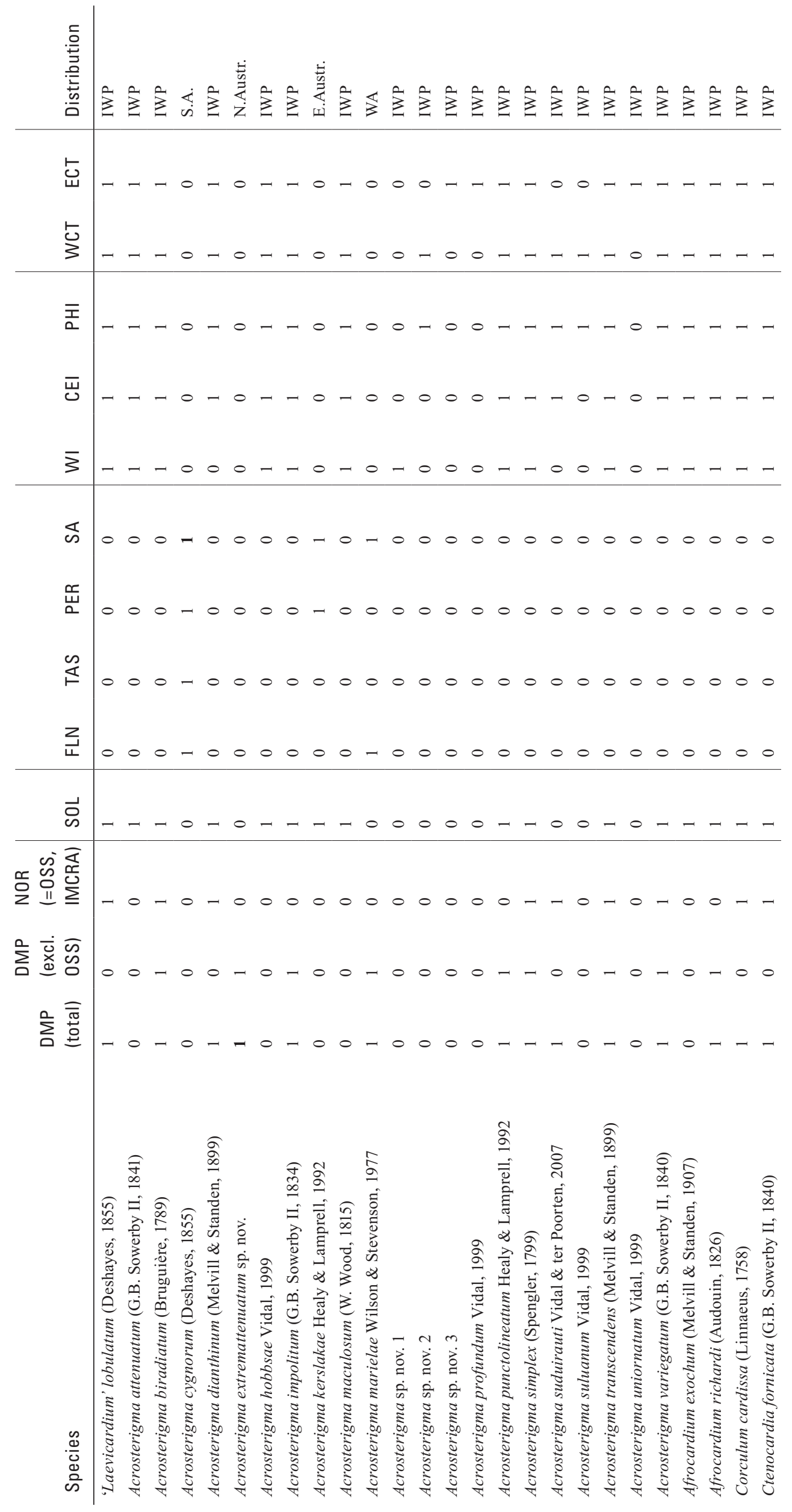




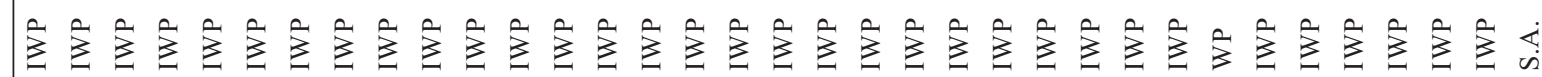

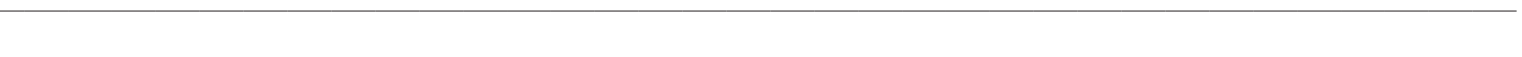

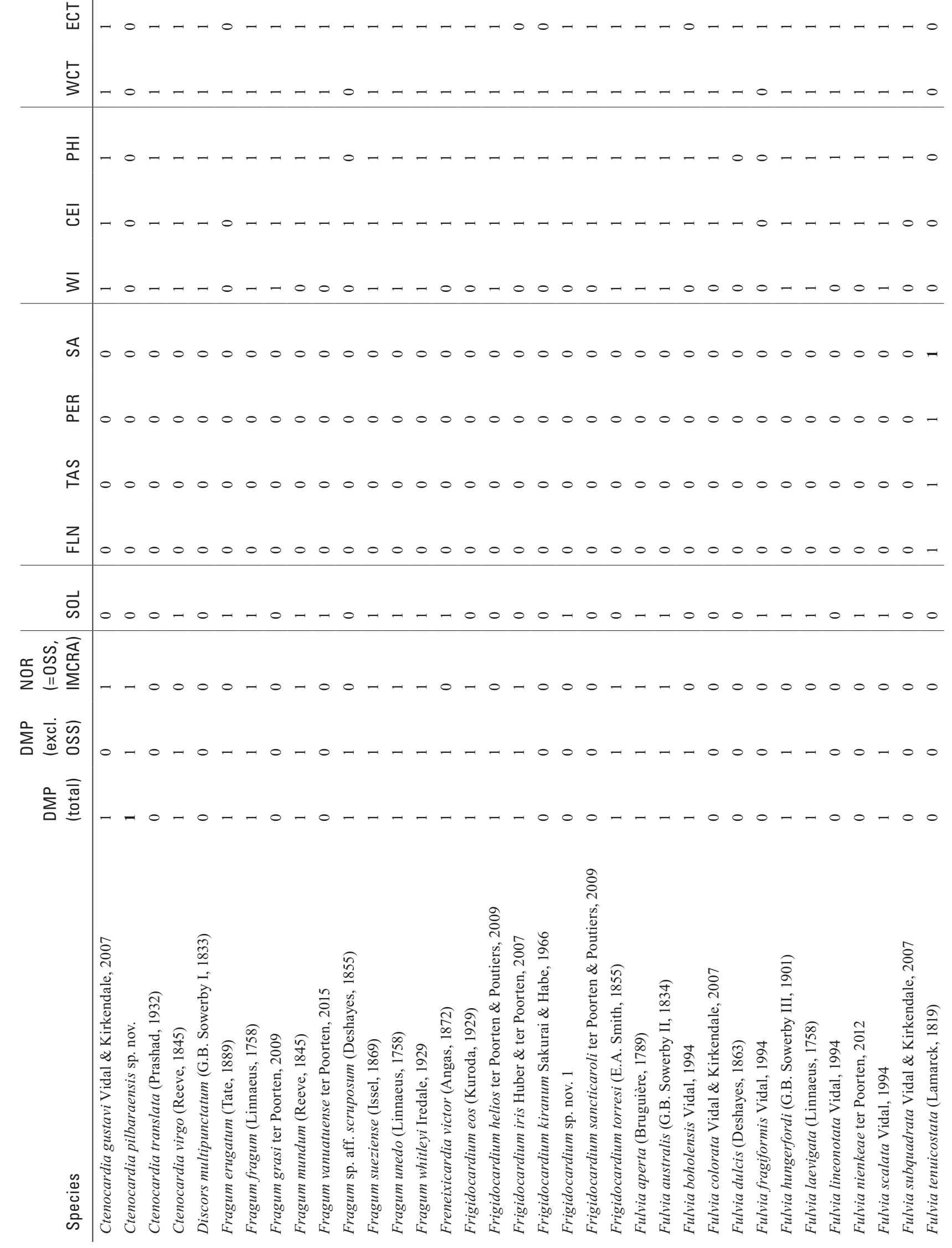




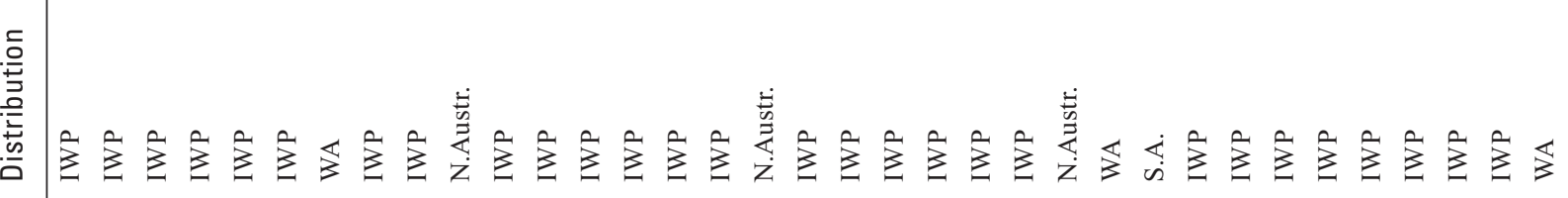
,

西

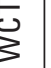

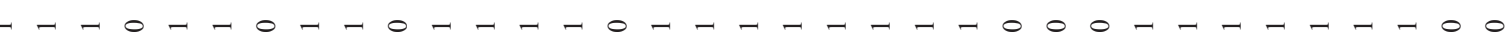

폼

Ш्త

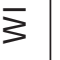

ふ઼

吕

$0000000000000000000000000-000000000$

$\stackrel{\infty}{1}$

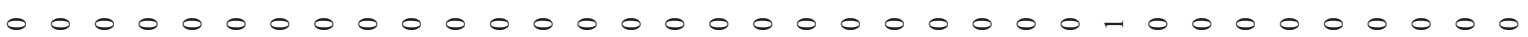

$\underset{\amalg}{\gtrless}$

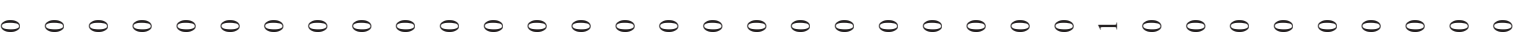

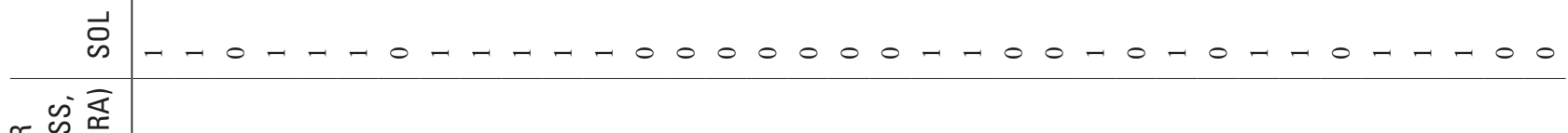

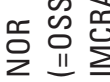

$\sum_{0} \overline{\dot{0}} \overline{0}$

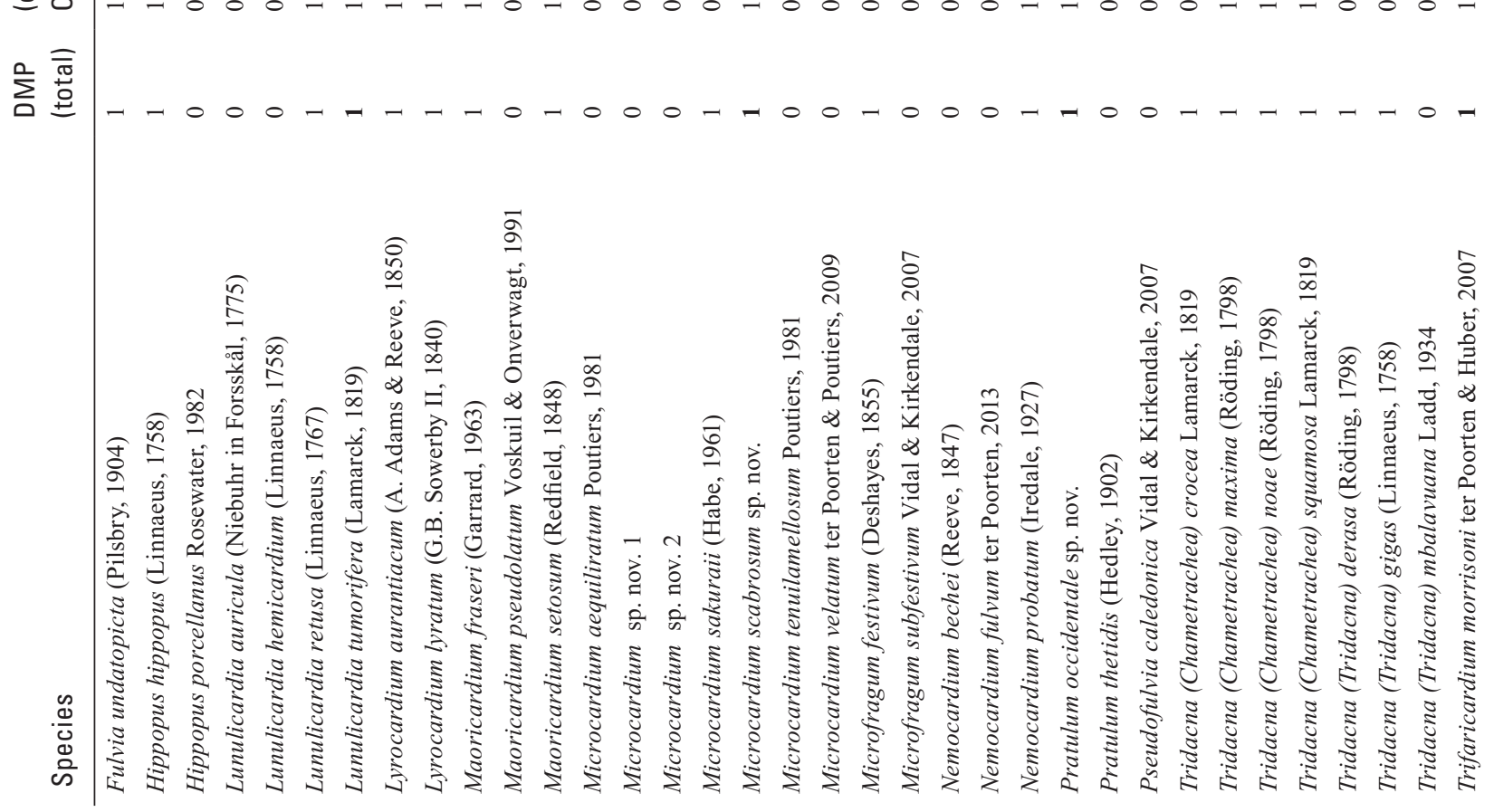



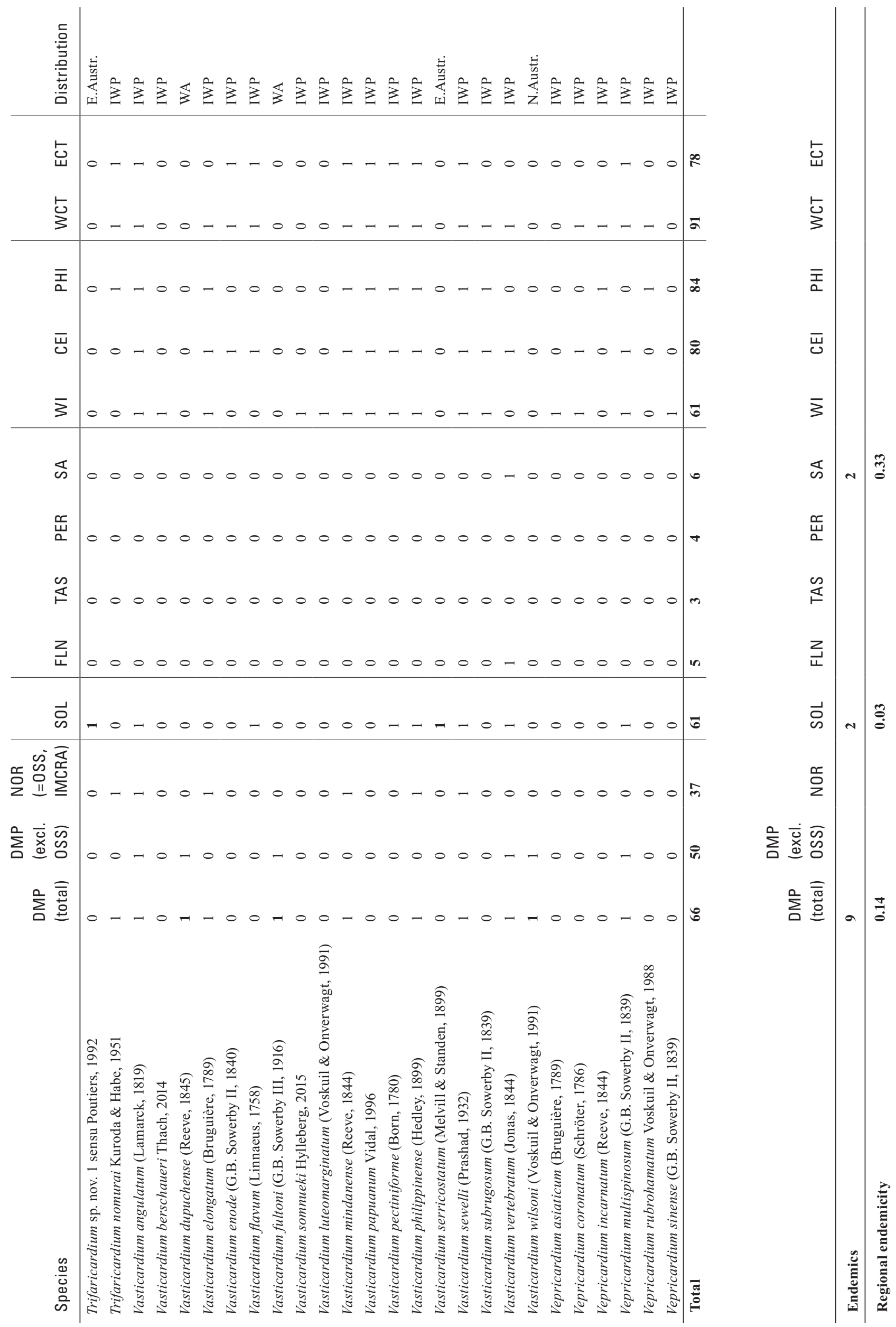